

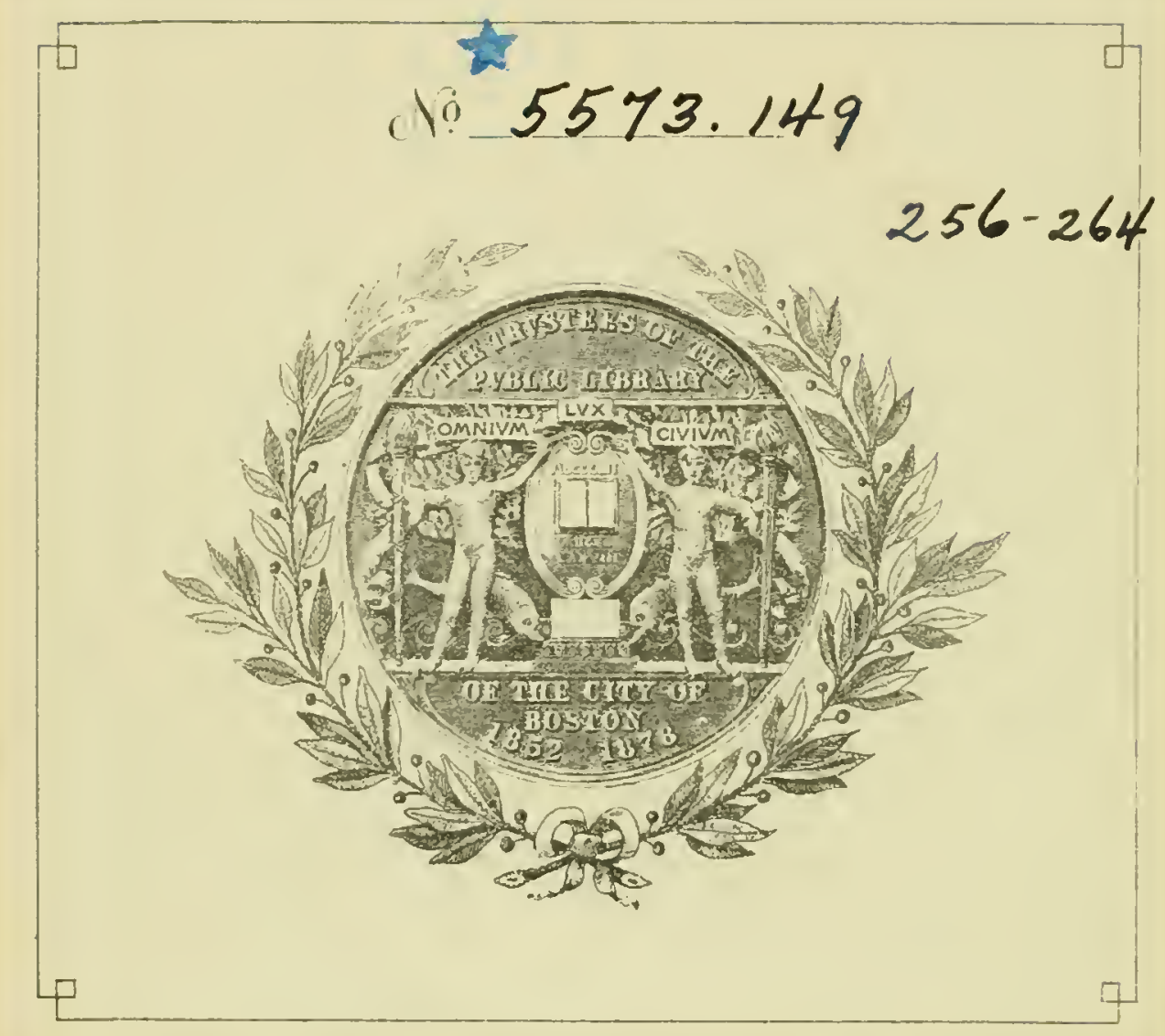





\section{Methods of Assessing}

\section{the Physical Fitness of Children}

Bureau Publication No. 263

UNITED STATES DEPARTMENT OF LABOR

CHILDREN'S BUREAU 

UNITED STATES DEPARTMENT OF LABOR

Frances Perkins, Secretary

CHILDREN'S BUREAU - Katharine F. Tenroot, Chief

\section{Methods of Assessing the Physical Fitness of Children}

A study of certain methods based on anthro. pometric, clinical, and sociocconomic observations made of 7137 -year-old white boys and girls in New Haven, Conn., over a period of 19 or 20 months during 1934-36

By

RACHEL M. JENSS, Sc. D.

and

SUSAN P. SOUTHER, M. D.

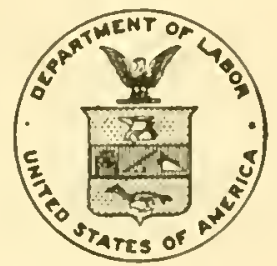

Bureau Publication No. 263

United States

Government Printing Office

Washinglon : 19.10

For sate by the Superintendent of Dencuments, If ashington, 1). C 
U. S. SUPLFily GEA ENT OF DOCUIERTS

NOV $25 \quad 1940$ 


\section{O N T E N T S}

Letter of transmittal

Introduction

Methods of assessing physical fituess . . . . . . . . . . . . . . . . . . . .

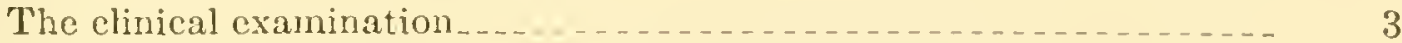

Biochemical tests for specific nutritional deficiencies.............. 4

Functional tests . . . . .

Dictary inquiry . . . . .

Socioeconomic inquiry _.............. 5

Anthropometric measures of body build _................. 5

Indices of body build as a method of assessment of physical fitness _...

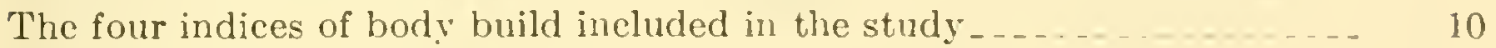

Deseription of each index of body build . . . . . . . . . . . . . 10

The Baldwin-Wood Tables_._._.

The ACH (Arm-Chest-Hip) Index.................. 11

The Nutritional Status Indices....................... 13

The Pryor Width-Weight Tables_....................... 17

Limitations of the four indices of body build ................. 18

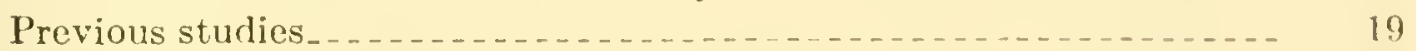

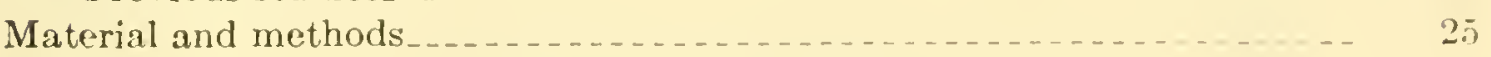

A description of the boys and girls ineluded in the study ........ 27

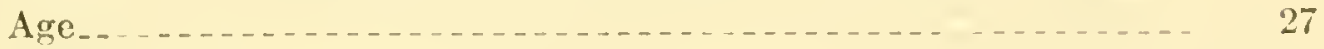

Nationality .

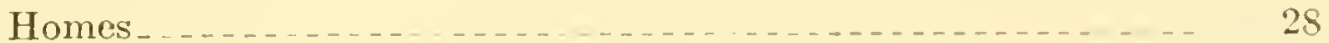

Location . . . . 28

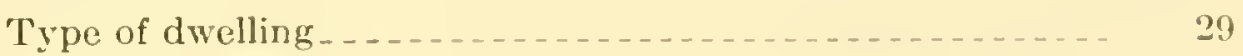

Presence of parents in the home $\ldots \ldots \ldots \ldots$

Number of persons in household ............. 30

Number of persons per room _... . . . . . . . . . . . . 31

Number of additional persons slecping in the child's bedroom _ $\quad 32$

Eeonomic status of their families . . . . 32

Assistance_............... 32

Principal source of income ................ 33

Employment of mother. . . . . 33

Anthropometric measurements _................. 34

Height. . . . . . .

Weight

Dicts

Health _...

Pediatrician's assessment of general nutritional status _ _ 36

Diagnoses made at annual physical examinations _........ 37

Number and duration of reportable school absences... . 35

Medical and dental care.......... . . . . . . . 3 ?

Summary _...

The observations made of these children ....... . . . . . . . . 4 1

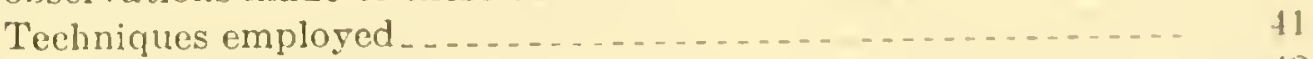

Clinical assessment. .............................. 42

Anthropometric measurements................. 44 
Material and methods-Continued.

The observations made of these children-Continued.

Accuracy of the techniques employed .................. 45

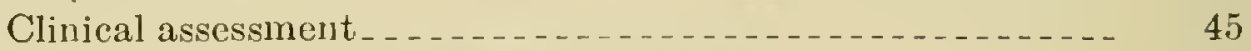

Anthropometric measurements _.................... 45

Socioeconomic and related data_.................. 48

Summary of material and methods_..................... 49

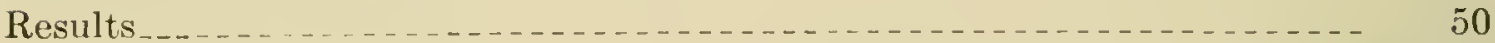

Indices of body build _............. 50

The problem of testing the indices_....................... 50

Criteria for testing the indices_.......................... 50

Observations used in deriving criteria _................. 50

Description of the criteria_....................... 51

Number of children selected by the criteria . . . . . . . . . 53

Evaluation of the criteria $\ldots \ldots \ldots$

Testing the indices_._._. 55

The Baldwin-Wood Tables _._.

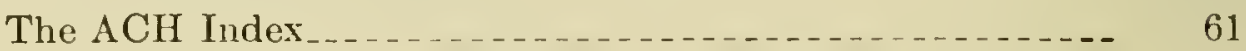

The Nutritional Status Indices_..................... 63

The Pryor Width-Weight Tables_..................... 74

Summary

Clinical judgment_........... 76

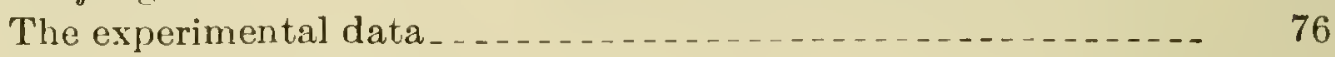

Review of the literature $\ldots \ldots \ldots 78$

Variability of clinical judgment in the present study _......... 82

Stability of clinical judgment in the present study ........... 85

Opinions and recommendations of others_............... 87

The need for improving clinical judgment $\ldots \ldots \ldots \ldots . \ldots 2$

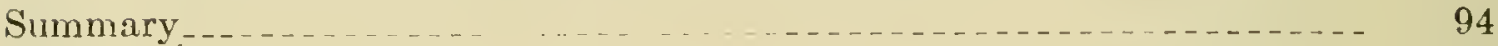

Appendix I _ _............. 97

Statistical methods_._.

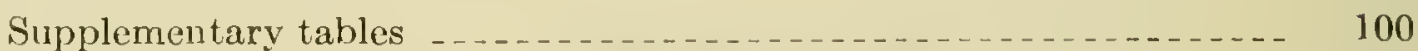

Appendix II _.

List of references $\ldots \ldots$

\section{ILLUSTRATIONS}

Map.--Location of the homes of the children

Grapl.-Weight of Italian boy, A. R., observed at frequent intervals from 72.7 to 92.8 months of age 


\title{
Letter of 'Transmittal
}

\author{
United STates Departinent of Labor, \\ Chindrian's Bureau, \\ Wrashington, August 15, 1940.
}

MADAm: There is transmitted herewith Methocts of Assessing the Physical Fitness of Children, a study based on observations made in New Haven, Conn.

The problem of finding an efficient, economical, and simple method of assessing physical fitness has occupied the attention of workers in the field of child health and growth for many years. Recently a number of methods have been recommended, especially those based on anthropometric measurements of the child. Some of these procedures have been in more or less widespread use but few attempts have been made to evaluate the diflerent methods as applied to the same group of children and to compare the relative eflectiveness of these methods in identifying boys and girls who are physically unfit.

Several years ago it was decided to make such an evaluation of several methods of assessment, including (1) indices of body build and (2) clinical judgment of general nutritional status.

The study began in 1934. It was a cooperative undertaking of Yale University through the Institute of Human Relations and the department of pediatries of the School of Medicine and of the Children's Bureau of the United States Department of Labor, in cooperation with the Department of Health and the Board of Education, New Haven, Comn.

The study was proposed by Frank $K$. Shuttleworth, Ph. D., of the Institute of Human Relations, who participated in outlining the original schedules and who made preliminary statistical analyses of the data. It was earried out under the direction of the following members of the respective staffs: Mark A. May, Ph. D., Dirceter of the Institute; Grover F. Powers, M. D., Professor of Pediatries, the Yale University School of Medicine; and Martha M. Eliot, M. D., Assistant Chief of the Children's Bureau.

The general supervision of the field work and the physical examinations were carried out and a preliminary report of the clinical aspects of the study was prepared by Susan P'. Souther, M. 1). now of the Commeticut State Department of Health and formerly on the stalf of the Children's Bureau; the anthropometrie measurements were taken by Mary E. Parker, R. N. Assistance in some of the clinieal and anthropometric aspects of the study was given by Ethel C. Dunham, M. D., and Clara E. Hayes, M. D., of the Children's Bureau, and 
Sander E. Lachman, M. D., then on the staff of the Institute of Human Relations, Yale University.

After the observations were collected, the analysis was directed and the final report prepared by Rachel M. Jenss, Sc. D., statistician in charge of studies of child health and growth, Division of Statistical Research, Children's Bureau.

The study has been confined to the problem of evaluating several methorls of assessing physical fitness which have been in more or less widespread use in this country during recent years. It has not, attempted to ascertain why certain methods fail nor has it undertaken the problem of developing new methods of assessment.

It is hoped that the report will resolve some of the difficulties and confusion which have existed concerning the more generally accepted methods of assessment of physical fitness, and that later a more constructive approach can be made to the problem of assessing the physical fitness of school children.

Acknowledgment is made to Robert J. Myers, Ph.D., Director of the Division of Statistical Research, and to the following members of the section on child growth and development, Division of Statistical Research, for assistance given in the analysis and preparation of the report: Marie G. Fullam, Mollie Orshansky, Helen R. Robinson, and Lois F. Smith.

Respectfully submitted.

Hon. Frances Perkins,

Katharine F. Lenroot, Chief.

Secretary of Labor. 


\section{METHODS OF ASSESSING THE PHYSICAL FITNESS OF CHILDREN}

\section{Introduction}

The importance of safeguarding the child's health and physical fitness, not only for his own sake but also for the welfare of society, is axiomatic. It follows directly that if his health is to be protected, the child must be observed at regular intervals in order to ascertain his physical condition and to determine whether he needs medical attention or nutritional advice and assistance. How is such an assessment to be made? Various methods are available. Some of them are elaborate, others are more simple; some are based on clinical examination, others depend on exacting laboratory techniques or are derived from anthropometric measurements of the child. It is important to know the relative value of these procedures. Which of the various methods of assessment in use in this conntry at the present time may be both easy and inexpensive to apply, and productive of results?

This question forms the basis for a study of the physical fitness of 7-year-old white boys and girls ${ }^{1}$ living in New Haven, Conn., from September 1934 through May 1936. ${ }^{2}$ The investigation was undertaken by the Children's Bureau of the United States Department of Labor, the Institute of Human Relations of Yale University, and the Department of Pediatrics of the Yale University School of Medicine, in cooperation with the Board of Education and the Department of Health of New Haven.

Before describing the materials and methods of this study, it may be well to define the term "physical fitness" and to outline each of the methods of assessment. Physical fitness is a comprehensive tem which is broader than either health or nutrition. It includes the child's general nutritional status and the presence or absence of organic defects, both considered in relation to his general physical condition evaluated in terms of his own previous growth and development. Unfortunately, it is rather elusive of definition and diflicult

\footnotetext{
1 Age is deflned in completed years on the last birthidas.

2 The children were examined for the first time whon they were fo gars whl, luat the rejurt is hased on the observations made when the hoys and girls were 7 yeurs of age, aujlined and inferperserl in relation fo the earlier findings.
} 
to determine because of the fact that it evaluates the child's present condition as a functional state which is partly the result of previous growth and which, in turn, will affect his future health and well-being.

The child's physical fitness is related to a large number of factors, both endogenous and exogenous. Perhaps most intimately associated with his physical well-being are the child's present health and nutrition as well as his psychological state, each judged in relation to his heredity, his general disease history, and his previous growth and development. But equally and sometimes even more important is the child's socioeconomic background, because it is safe to assume that if the family's income is below a certain level, the child runs the risk of being physically unfit as a result of unsatisfactory living conditions ${ }^{3}$ and of a suboptimal intake of the proper dietary constituents. Although it is difficult, if not impossible, to point out all the factors ${ }^{4}$ which may play a role in affecting the child's physical fitness, it may be said in summary that the child's well-being is dependent not only on his present condition but also on his previous history (familial, antenatal, and postnatal). 'Together they determine his ability to compensate for or overcome his present defects and handicaps, and his future incapacities as well.

It is obviously impossible at present to appraise correctly a child's physical fitness. Not all the factors that affect a child's well-being nor their interrelationships are known; no satisfactory methods of measuring some of these factors are available; and many procedures which are satisfactory for judging specific aspects of a child's condition are too elaborate for widespread application, or the cost involved prohibits their inclusion in a school health program or a community survey.

\footnotetext{
3 The term "unsatisfactory living conclitions" is used to include such factors as overcrowding; short hours of sleep or lack of conditions for sound, restful slecp; poor ventilation; and lack of sunlight.

+ Home hygienc, as well as discipline and control both at home and in the school, must also be considered.
} 


\section{Methods of Assessing Physical Fitness}

Several methods of assessing physical fitness are in use at the present time. They include the clinical examination, specifie biochemical tests for particular nutritional deficiencies, tests of functional wellbeing, dietary and sociocenomic surveys, and anthropometric measures of body build.

\section{The Clinical Examination}

The child's "apparent" physical condition can be assessed by a physician. This examination will obviously reveal such conditions as thinness, faulty posture, flabbincss of muscles, and certain marked nutritional or organic defects, but at best it gives only an approximate evaluation. 'There is an increasing realization of the difficulties of assessing a child's condition by this method alone.

In an article on the incidence and assessment of mahnutrition Harris discusses four sourees of error. ${ }^{2}$ They are summarized as follows:

1. Inadequate clinieal methods are used. Examinations are usually carried out under cireunstances which require the inspection of large numbers of children in a relatively short time. Consequently laboratory techniques or the more refined methods neepsary for deteeting the presence of early or slight malnutrition are usually omitced.

2. Debased standards are used. It is commonly known that sueh figures as those for the average weights and heights of school children of a given age and sex have undergone a steady and marked rise during recent years. Furthermore, the average weights and heights of groups of ehildren who have been fed on approved dietaries have increased beyond the weights and heights of emparable groups of children who were given neither appropriate nor supplemental diets. It is obrious. therefore, that standards which redy on past arorages instead of on more recent and comparable data are dependent on the use of a debased norm, and hence, always tend to be underestimates.

3. No standards are known for assessing malnutrition; comserpuently no satisfactory way of measuring it exists.

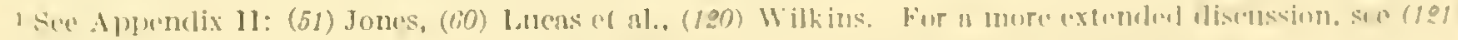
Wilkins. The italicized numbers in parentheses refor to the numberend list of references fo lue fouml in Apludix 11, p1, 115-121.

2 See Appondix II: (44) 11 arris, p1. 225-226.
} 
4. The effects of malnutrition are delayed. Of the failure of a superficial clinical examination to reveal abnormal conditions which may have a delayed effect, Harris says:

It is obvious that the grosser results of malnutrition can generally be detected readily enough by the elinical observer *** . It is rather the earlier effects, the influence of partial deficiencies, which may pass unobserved if reliance be placed on cursory clinical examination-and yet these "milder," less readily detected, types of deprivation may none the less have a profound influence, delayed it may be, on the health and well-being of the subject. ${ }^{3}$

\section{Biochemical Tests for Specific Nutritional Deficiencies}

Biochemical tests can be made for particular deficiencies including the vitamins, the inorganic elements such as iron, calcium, phosphate, and other important dietary constituents. Many of these tests are complicated and expensive; otlrers, particularly those for the vitamins, lack specificity or sensitivity; all of them have limited value in assessing physical fitness because they measure only particular nutritional deficiencies.

\section{Functional Tests}

Under the general heading of functional tests may be included, among others, tests of lumbar pull (on a dynamometer), rital capacity, and basal metabolism." Many of these techniques are still in a developmental stage and require further study and application before satisfactory norms are available. But even when such standards have been developed, giving the tests will require special training or equipment and will, therefore, be beyond the reach of the average publichealth officer or school official. Furthermore, they give only a partial answer to the question "Is the child physically fit?"

3 See Appendix II: (44) Ilarris, p. 225.

$+(87)$ Pryor and Smith give a brief review of the history of strength tests, including the use of the ergograph and Kellogg's universal dynamometer, and Sargent's chinning and dipping tests to judge endurance. Galton's tests of reaction time to auditory ancl visual signals are also mentioned.

For ilhstration of the use of tests of vital capacity and tests with the spring dymamometer, see $A$ ppendix II: (19) Cheesman, (118) Warrington [England], reference to Magce in (44) Harris, p. 227, (69) Milligan, and (128) Woolham and Sparrow. See (118) Warrington [England] for application of the Romberg test for determining a child's power of equilibration and coordination and (127) Woolham and Honeyburne, for pulse and respiratory tests.

For attempts to use standard athletic performances such as the 60-meter race, ball throwing, and jumping as indieations of physical fitness, see (129) Wroezynski, p. 673.

Stamlar ls based on combinations of various tests of physieal performance have also been derived. For ("xample, a physical-fitness index has been leveloped by (92) liogers. See also (128) Woolham and Sparrow for a pliysiological formula developed by Flack and Woolham. 


\section{Dielary Inquiry}

A detailed inquiry may be made into the dietary habits and environment of the child in order to estimate his nutritional status. ${ }^{5}$ Wilkins, pointing out the fundamental importance of this aspect of the problem, writes:

Workers in animal uutrition know only too well that a diet must be tested, not only through the whole life of the individual, but through at least three or four generations before it can be passed as fully adequate. Yet it is customary to pass children, the most valuable animals of all, as normal in their nutrition, and, presumably, therefore to pronounce their diets fully adequate in each and every constituent, without any inquiry into the details of their diets, and without eren testing the efficieney of a single bodily function. ${ }^{6}$

Making detailed dietary inquiries is, howerer, difficult. They aro also expensive and time-consuming, for they require the services of well-trained observers and the whole-hearted cooperation of the child and his family.

\section{Sociocconomic Inquiry}

An estimate of the net family income per capita gives a fairly reliable basis for estimating whether a satisfactory diet is purchasable, because, as Wilkins has pointed out, "Enough work has been dome on family budgets and minimum costs of living to enable us to make a rough estimate of the mutritional possibilities of any family." 7

On the other hand, although it is inevitable that if the money available for food is inadequate the child's dict is unsatisfactory and his health suffers, it should be pointed out, as is stated in an editorial which appeared in the Jomnal of the American Medical Association, that "malnutrition is no longer considered to be cxclusively an outcome of poverty or bad environment." s

\section{Anthropometric Measures of Body Build}

Because of the difficulties involved in the application and the appraisal of the techniques that have been discussed, allompts were begun to derive indiees of body build, based on the intrrrelations of

s See Appendix II: (18) Boudrean and Kruse, (44) llarris, (89) Roburts, and (121) Wilkins

For diseussion of what constitutes an adequate diet, see Appendix 11: (96) Friend, (\$1) Grent 13ritain .11in. istry of Health Advisury Commitler on Nintrition, (6l) MCCarrison, (8) Rose. (10,3) Sherman, and (100? Stiebeling and Clark.

o See Appendix 11: (121) Wilkins, p. 145.

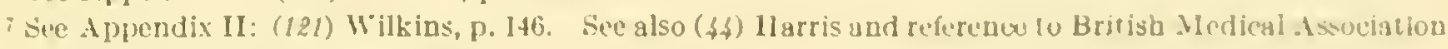
Committec on Nutrition in (44) Harris, and (89) Roberts.

8 See Aplendix 11: $(4 \gamma)$ Index's of Niutrition, p. 1256. 
certain anthropometric measurements. ${ }^{9}$ These indices are used to predict a measure of the child's well-being, such as his weight or arm girth in terms of his physique or body build. They assess physical fitness only insofar as it is related to abnormalities in such measures.

Four of these indices, which have received widespread application in the United States, have been applied to the children included in this study: ${ }^{10}$

(1) The Baldwin-Wood Tables published in 1923.

(2) The ACH (arm-chest-hip) Index developed and published by the American Child Health Association in 1934.

(3) The Nutritional Status Indices of Franzen published by the American Child Health Association in 1935.

(4) The Pryor Width-Weight Tables published in 1936.

These indices are based directly or indirectly on statistical techniques (multiple-regression procedures) which are not always employed in the development and application of other methods of assessment. For this reason it is probably advisable to describe in some detail the fundamental hypotheses on which they have been based, the possible limitations of this type of approach, and the exact methods of applying and evaluating each index, and to review critically other studies which have been made to test the effectiveness of these indices in identifying children who may be in need of medical care or nutritional advice and assistance.

\& This type of index is to be distinguished from simple ratios, which have been in use for a great many years, althongh they are not generally applied in the United States at the present time. As early as 1829 , Buffon reported sneh an index or ratio in the form, $\frac{\text { Weight }}{\text { Height }^{3}}$. It was modified by Quetelet in 1836, by Rohrer in 1908, by Tuxford in 1917, and by Bardeen in 1920. Tuxford's modifieation was more elaborate than the others. He proposed the following formulas as a measure of the physical development of school children:

$$
\text { For hoys: } \begin{aligned}
\text { Weight (kg.) } & \text { Height (cm.) } \\
\text { For girls: } \frac{381 \text {-age in months }}{54} & \frac{\text { Weight (kg.) }}{\text { Height (em.) }} \times \frac{381-\text { age in months }}{45}
\end{aligned}
$$

During the World War I'irquet developed a system for assessing nutrition which ineluded a ratio based on weight anc stem length. It is known as the "pelidisi" index and depends on the relationship

$$
\sqrt[3]{\frac{\text { Wright } \times 10}{\text { Stem length }}}
$$

Other measurements have also been used in deriving this type of index. For example, as early as 15S6, Bernhardt used the following formula for predieting weight:

$$
\text { Weight }=\frac{\text { Meight } \times \text { Chest measurement }}{240}
$$

and in 1901, Oppenheimer fut forth a "nutritional quoticnt" defined by the ratio

Maximum girth of relaxed arm $\times 100$

Chest eireumference at end of expiration

Other indiees may be mentioned which illustrate the use of combinations of tests of physical nerformance. One is a physiological formula known as the Flack-Woolham product (1923). The sceond is an anatomieal ratio ealled tho Dreyer produet (1919).

For a more complete description seo Appendix 11: (82) Paton and Findlay, pp. 51-57, on which most of the ahove diseussion is hasel. See also (27) Dreyer, (89) Roberts, pp. 57-83, (114) Turford, and (128) Woolham and sparrow.

10 Ser Appendix 1I: (6) Baldwin and Wood, (35) Franzen and Palmer, (75) Nutritional Status lndices, and (86) P'ryor. 


\section{Indices of Body Build as a Method of Assessment of Physical Fitness}

A number of problems arise in studying these indices of body build. For example, the question is frequently asked: Can external measurements of the human body be used to assess a child's physical fitness, especially if there is an early or slight departure from health or if he is suffering from a mild form of nutritional disorder? Can they identify the child who is overweight but flabby or the one who is overdeveloped? It has been pointed out in this connection that such indices attempt only a quantitative evaluation of the child's condition and that the qualitative aspects are ignored. To be more specific: Can an index of body build differentiate between organic and dietary causes of undernutrition? Does it take inherited or constitutional factors into account? May not long-continued malnutrition have interfered with a child's growth to the extent that anthropometric measurements cannot be used to evaluate his physical - fitness?

It is also well to bear in mind that recent studies of weight and weight increments have shown that certain years are "good growing years" and others are not. ${ }^{1}$ Does this phenomenon aflect the value of the indices? Can seasonal variations in the measurements from which they have been derived be ignored?

Many other questions have been asked. A discussion of their significance has been omitted, however, since this investigation is concerned with the identification of children who may be physically unfit and not with detailed technical problems in methodologr. Nevertheless it may be worth while to indicate the nature of some of these questions.

For example, a great many statistionl problems arise in comnection with the development and application of these indiees. Do the hasic data comply with the hypotheses which the mathematical procodures require; $i$. e., are the anthroponetric measures normally distributed and is their relationship lincar? Are the mathematical procedures correctly applied? Is the teehnicque equally applicahle to beth sexes? To children of diflerent ages? Is the defintion of age used in deriving the indices too broad? Is an index more satisfactory if it is based on tongitudinal instead of cross-sectional datal? In other words, if

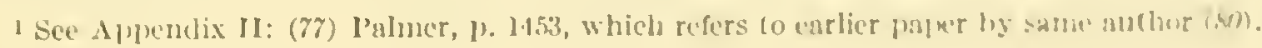


an index for 6-year-old and also for 7-year-old children is derived from successive measurements of the same group of boys and girls, is it more reliable than if it were based on measurements of one group 6 year's of age and another group 7 years of age?

In applying these indices the child's observed measure is judged in relation to the average or expected measurement of his skeletal peers. For example, the Baldwin-Wood Tables identify as skcletal peers children who are of the same sex, age, and height. These three factors are interrelated in such a way as to determine the child's expected weight, which is in reality the measurement for an average child of the same sex, age, and build (height). Now, such an average is dependent on the kind of children whose measurements have been included. If one assumes that the observations from which such an index has been developed are also representative of the group to which it is applied, the question still remains-how far does the average represent the normal, according to a dictionary definition of the latter term as applied in the medical and biological sciences - "conforming to natural order or law." 2

It should be remembered in this connection that the average anthropometric measurements of school children of a given sex and age have shown a stcady increase during the last 15 or 20 years. ${ }^{3}$ Does this evident change in physique necessitate the construction of new indices at certain intervals? Likewise, it has been shown that in experimental trials the average weight and height of groups of children who have been fed on improved dictaries have improved beyond the weight and height of the controls or of previously comparable averages. ${ }^{4}$ Do these findings indicate the use of debased standards?

One may also inquire: What are the standards of normal variation? How much may a child's measure deviate from the average and still be considered satisfactory? Is this deviation to be expressed in absolute or relative terms or by means of more elaborate statistical procedures?

It is essential also to know the kind of children whose measurements were used for deriving the indices. In other words, what racial, sociocconomic, and geographic groups do these boys and girls represent, and are they healthy children? In this connection it is interesting to note that the White Honse Conference of 1930 pointed out that most of the available standards do not represent desirable combinations of heritage, history, and home influence, and that further

\footnotetext{
Sece Appendix 11: (\$8) Gould, j). 961.

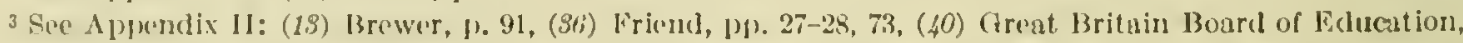

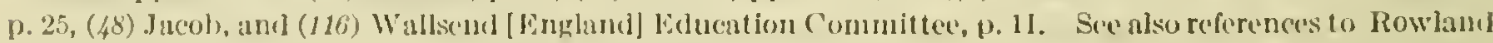
and stockwell contained in (99) Grent Britnin Buard of Educntion, p. 23, and sexe (129) Wroczyuski, [pp. 595-596, firs, for references to fiessard, Laufer and Laugier, Lioeh, and Wolff.

+ Sor Aplemdix 11: (44) 11urris, p. 226. Ifo refers to studies by Corry Mann, Leighton and Clark, Orr, and Scharil and Sinnadorni. See also (59) Loewenthal, (90) Roberts et al., and (105) Simpson and Wood.
} 
biometric work will be necessary to furnish norms for promoting useful application of measurement. ${ }^{5}$

Finally, in evaluating an index it is important to consider the children whom it fails to identify as well as those whom it selects as likely to be physically unfit, for although an index may identify some children who are in need of medical attention or nutritional advice and assistance, it may fail to seleet an even larger number of such children than it identifies. On the other hand, it may select not only all the children who are physically unfit but also a large number of healthy boys and girls. In other words, it is important to know just how efficient such an index is.

The preceding diseussion of the limitations of this type of approach, based on the prediction of one measure of the child's fitness in terms of its relation to his physique or body build, has not attempted to review critically the questions which have been raised, because this study is not concerned with the more technical aspects of evaluating these indices as a method of assessing physical fitness. ${ }^{6}$

\footnotetext{
5 See Appendix II: (119) White Honse Conference on Child Health and I'rotection, p. 323.

${ }^{6}$ It is suggested that the reader who is interested in the more technical aspects of evaluation consult such papers as those of (9) Bigwood, pp) 172-173, (94) Franzen, (49) Jenkins, (50) Jones, (65) Marshall, (7S) Palmer, (95) and (96) Rosenow, and (117) Warner, listed in Appendix II.
} 


\section{The Four Indices of Body Build Included in the Study}

Before giving a detailed description of the four indices included in this study, it may be well to reemphasize the fact that they evaluate physical fitness only insofar as it is related to abnormalities of certain measures of the child; for example, his weight or arm girth judged in relation to his body build.

\section{Description of Each Index of Body Build}

\section{THE BALDWIN-WOOD TABLES}

The index of body build based on the Baldwin-IWood Tables estimates a boy's or girl's weight in terms of his or her height (to the nearest inch) used as a criterion of body build at a given age (taken at the nearest birthday). Tables have been derived for ages 5 through 19 for boys and 5 through 18 for girls from which it is possible to determine what the child should weigh for his sex, age, and height (used as a criterion of body build). Then the difference between his observed and his expected weight is expressed as a percentage of the expected weight. Baldwin ${ }^{1}$ has allowed a deviation of less than 6 percent from the average or expected weight for any height, age (under 10 years), ${ }^{2}$ and sex for indivichal variations. A larger deviation (6 or more percent) indicates that a child is likely to be in need of medical attention. ${ }^{3}$

Measurements of an Italian child, A. R., who was included in the study, may be used to illustrate the computation of this index. (See sample schedule of physical measurements.)

It may be seen from this sample schedule that the Italian boy, A. R., weighed 46 pounds and was 44 inches tall when he was 7 years of age (7 years, 1 month, 6 days). According to the Baldwin-Wood Tables the average 7 -year-old boy who is as tall as A. R. weighs 44 pounds. In other words, A. R. was 4.5 percent overweight $\left(\frac{46-44}{44}\right)$ in terms of the Baldwin-Wood standard.

1. Sien Aprendix II: (5) Baldwin, p. 4 ,

$21 f$ the child is 10 or more years of age, Baldwin has altowed less than 8 percent variation. The majority' of workers, however, have allowed under 7 or less than 10 percent for children of all ages. See, for example, in Appendix 11: (22) Clark, Sydenstricker, and Collins, (28) Dublin and Geblart, and (90) Fmerson and Manny.

3 Aceorling to Baldwin, "children who are is pereent overweight for their lueight and age may also bo in nerel of melical attention" (ser Aprenclix 11:(5) 13aldwin, b. 4); but this aspect of tho problem of physical fituess has not been considered in the present report. 
PHYSICAL MEASURENIENTS

Children's Bureau, ¿'. S. Departanent of labor

Institute of Human Relations and Pediatric Departaest of yale UNIVERSITY

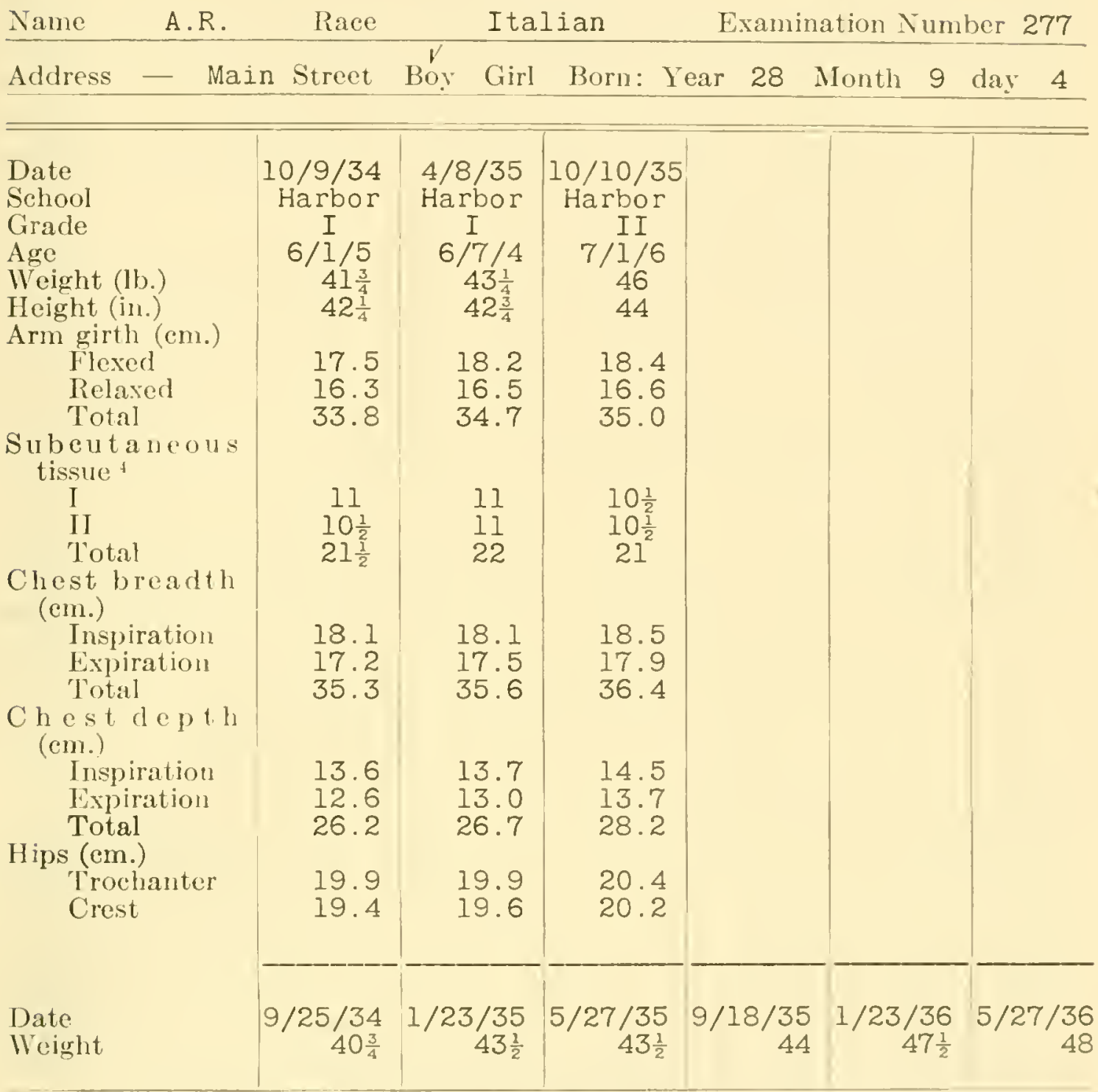

+ The 2 measurements for subcutaneous 1 issue were made according to the technirgue lleseribed in . Appendix 11: (75) Nutritional Status Indices, pl). b-10, using a special subcutameous-tissue culiper which has arbitrary units.

\section{TIE ACH (ARM-CHIST-IIP) INDEX}

The ACH Index was developed by the American Child Hoalth Association in 1934 and is "a screening technique constructed to meet the demand for a practical method of selecting. from a latge gromp), those children who nered a medical examination beeanse they have extremely smatl amounts of musculature and subcutancous tissur." 5 More speceifieally, "when the case is selected he is cortitin to have an arm-girth defereney and rery likely to be deficient in subeutaneous tissue and woight is woll." "6

8 ser Aplendix 11: $(\gamma \delta$ ) Nutritional status lntices, p. 1.

o See Iplpenrlix II: (S5) Jiranzen nud Palmer, p. I1. 


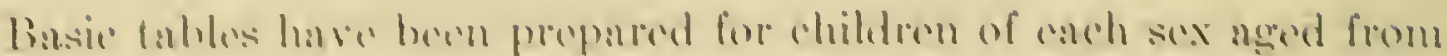

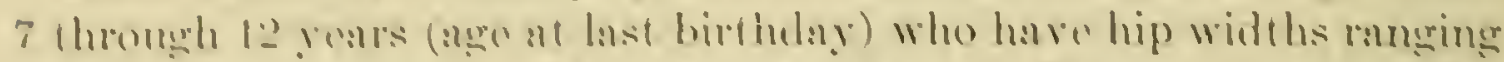

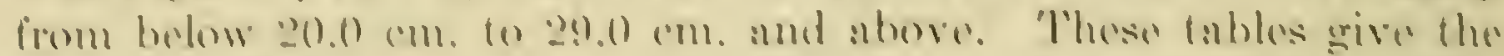

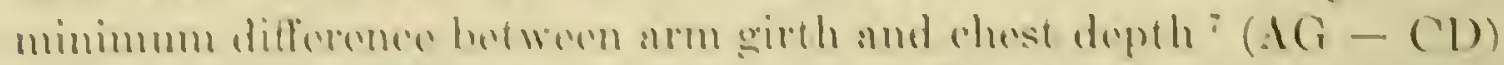

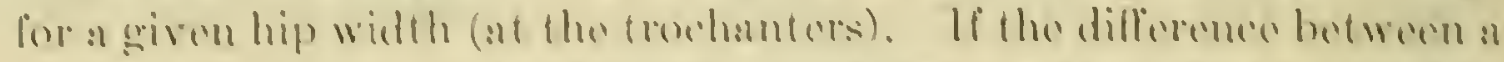

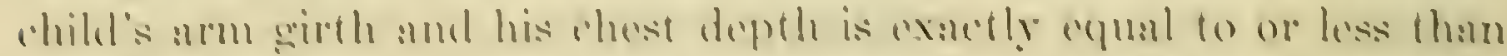

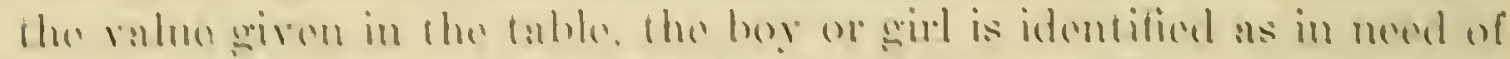

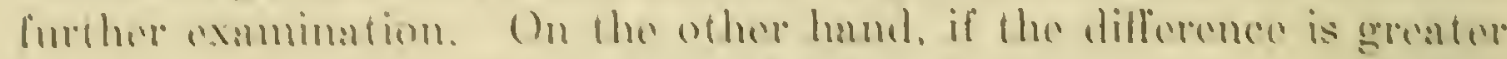

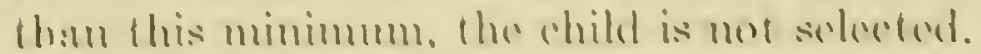

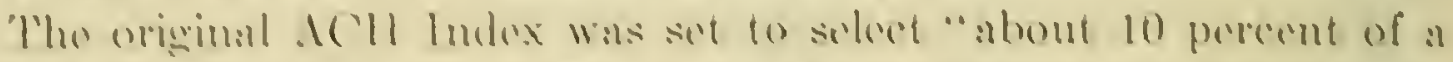

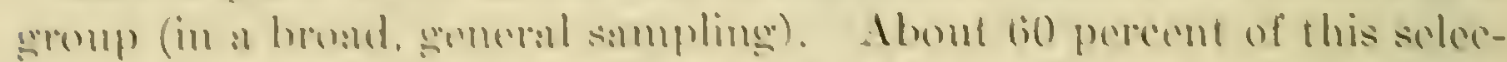

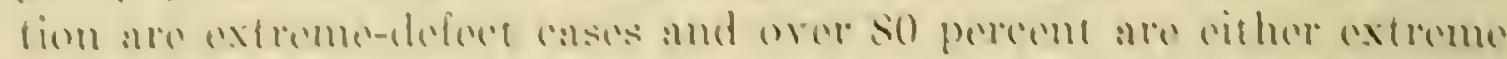

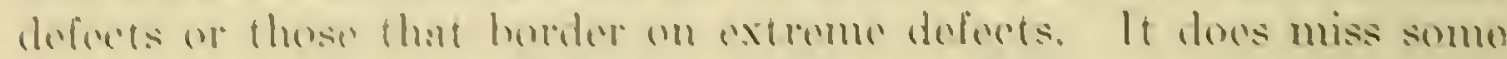

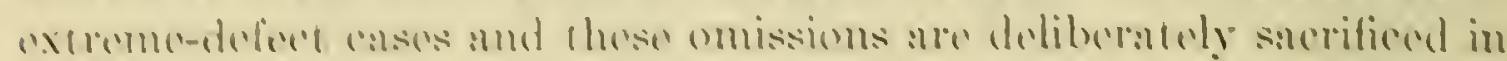
the inforest of spered and simplicity of mesturement." "The senle has

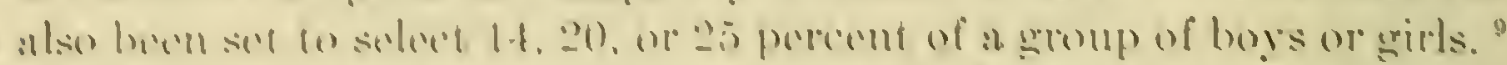

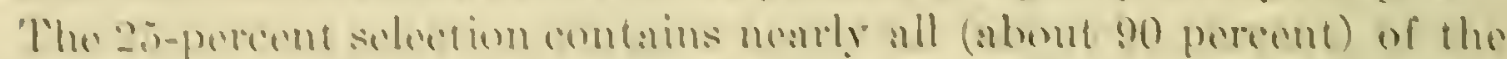

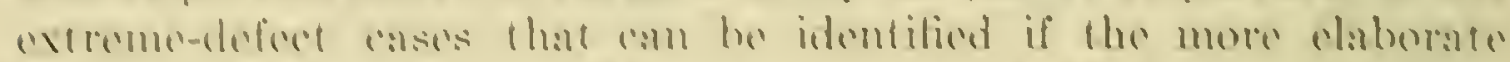

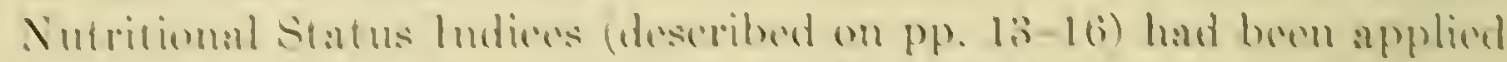

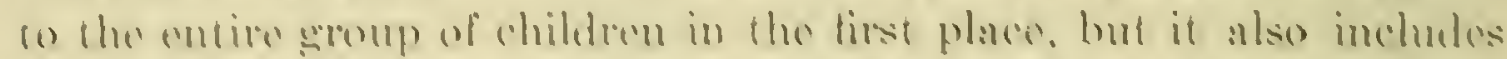

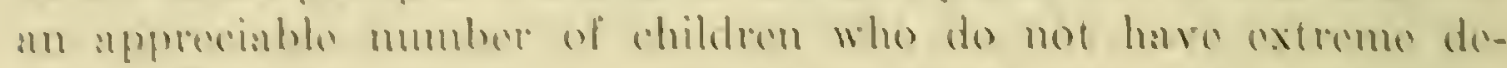

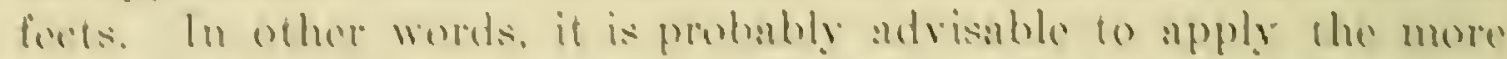

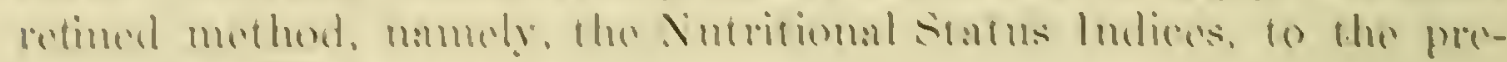

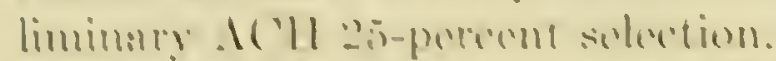

Thongh the indse sorens ont the children with "extromely small amemuts of soft tissur * * * it ders not make imdividual distine-

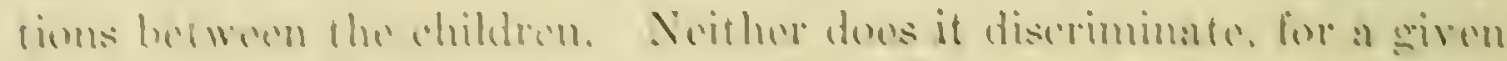

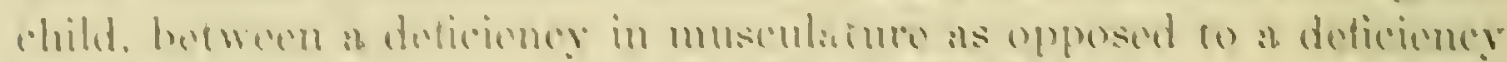

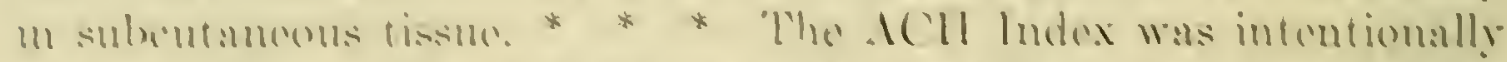

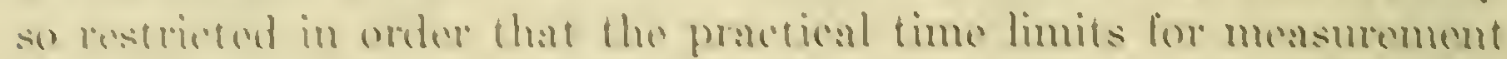

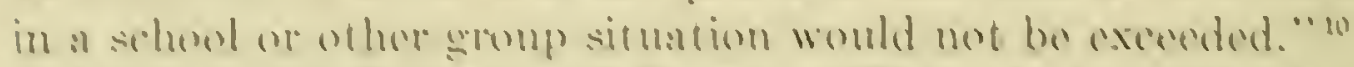

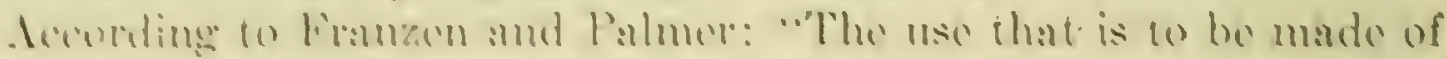
the index depends upon the ohjertives sought. If wo wish to be

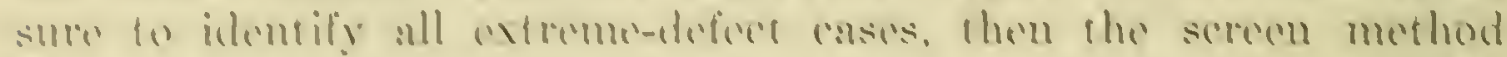

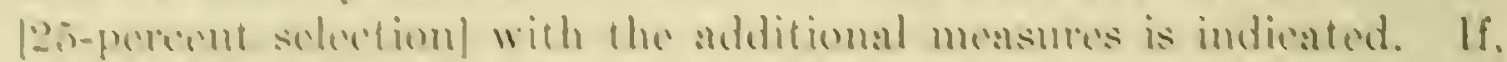
on the ofher hamd, this is not feasible and we are contont merely with

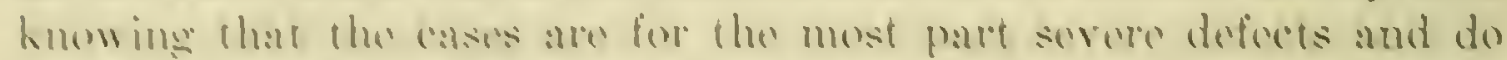

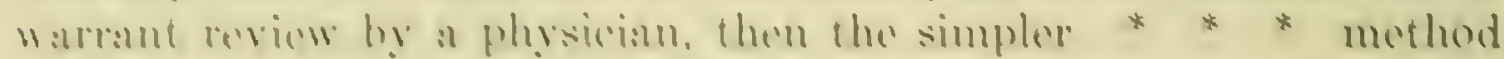

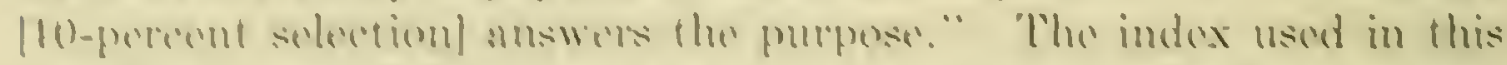
"ray "is infomded both as an aid to the physician and as a mass

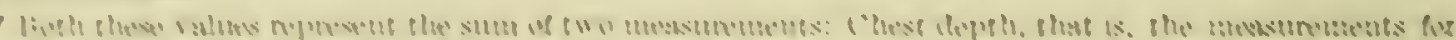

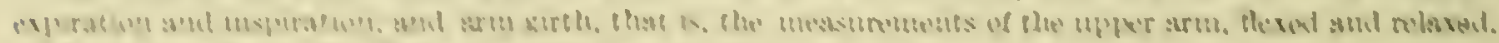

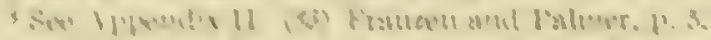

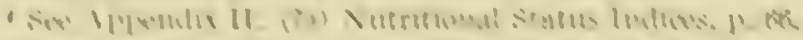

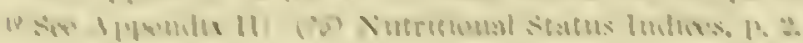


selective measure for comparing eroups." 11 If desired, the index may also be set to identify 14 pereont or 20 pereent of the dhilderen.

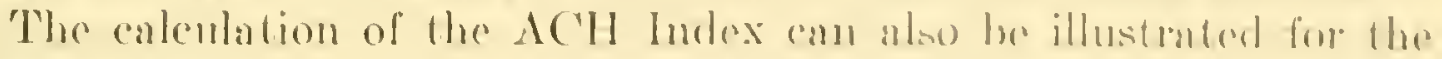
Italinn boy, A. R. The simple scherdule of phrsionl monsmemonts (see p. 11) shows that at 7 years of and he hat an arm-trinth moisure-

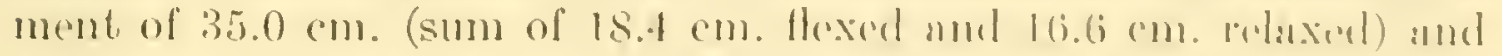

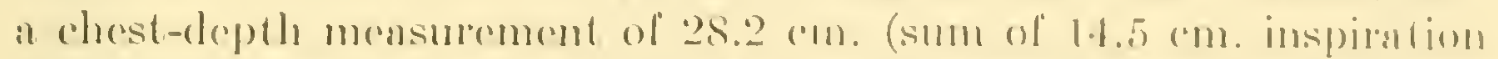

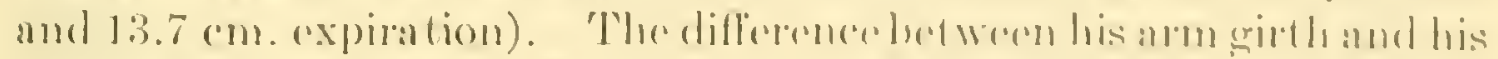
ahest depth is 6.8 cm. 'The widh of his hips at the trendanteres was $20.4 \mathrm{~cm}$. The tables show that low a boy of 7 yous with al hip width between 20.0 cm. and 20.4 an. Her minimum diflerence botwern the

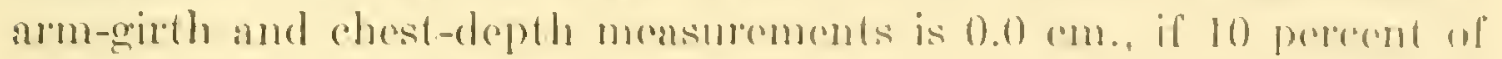
the group of boys are to be identified: ${ }^{12} 0.5$ com., if 1.4 perenent; ${ }^{13}$

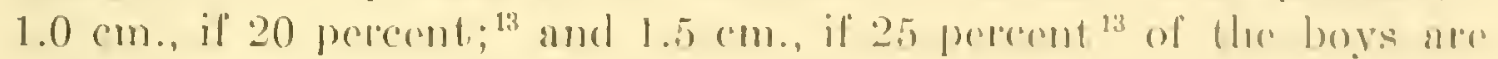

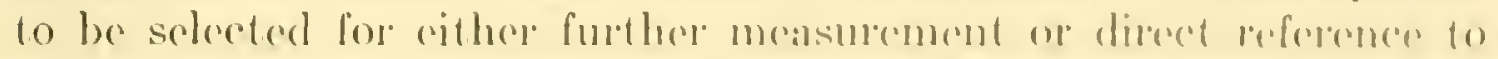

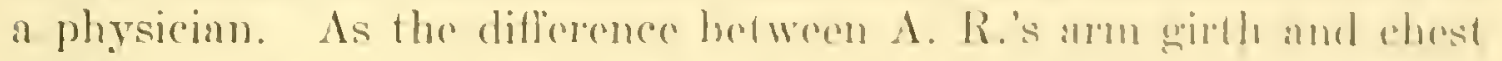

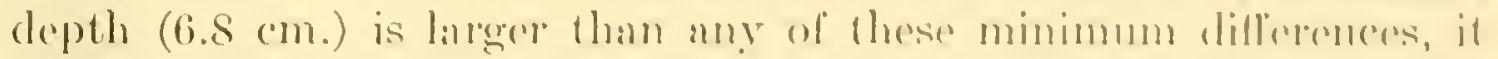
follows that he does not fall in the lowest 10, 1.1, 20, or 25 perent of

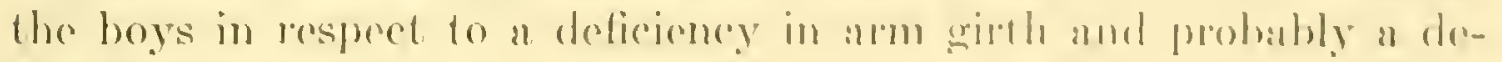
ficioncy in subcutaneous tissur and woight als woll."

\section{TIIE NUTIRTIONAT, STATUS INDIClis}

Tables for the Nutritional siatus Indiens were deredeped by Franzen and his coworkers in the Amoriand Child Ilonth Association in 1935. They may bo nsed to cralunte a child's condition from 7 through 12 yours of age (age at last birthelay) in terms of his woright, muscle size (as indieated by the eried of the uppere andu), and the

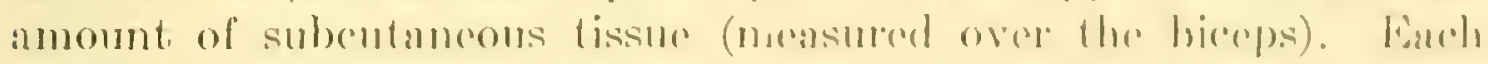

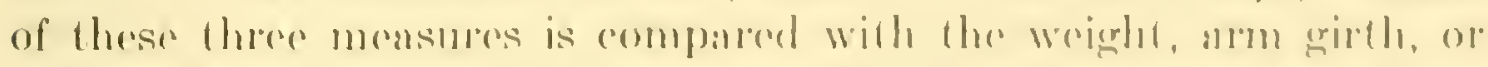
subeutaneous tissure which the arerange child of the same sex and urere

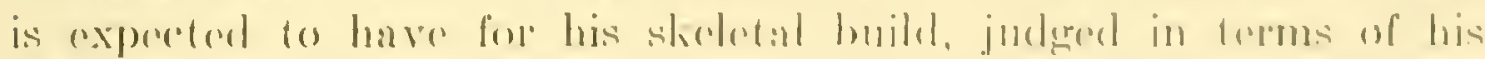
leright, the width and diphth of his chest. and his bitrochanterie widtls.

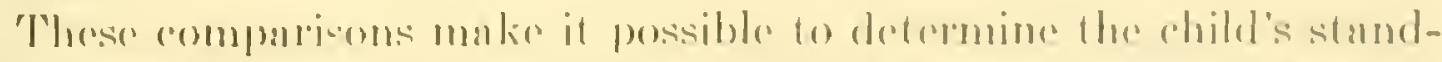

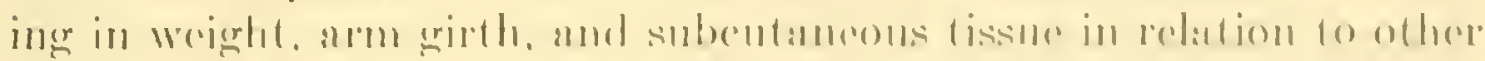

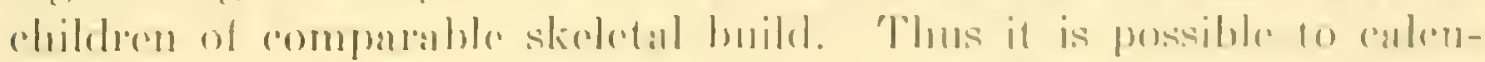
late the number in 1,000 childeren of the same sex, ane, and skintent

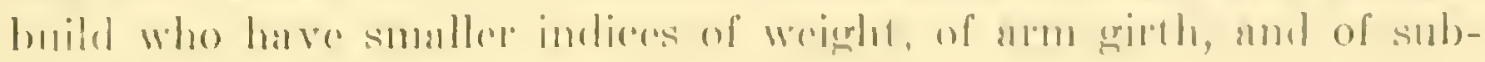
cutamens tissone than the rhild rammined.

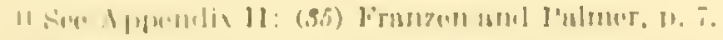

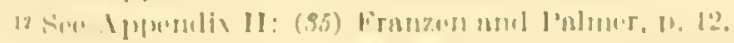

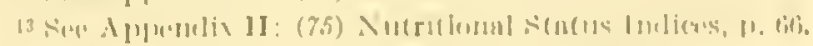

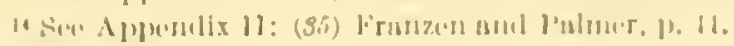


This procedure was devised not only to reveal differences in the nutritional status of children ${ }^{15}$ but also to discriminate between a deficiency in musculature and a deficiency in weight or subcutaneous tissue, "a distinction that is important if differential diagnosis of nutritional status is to be made." 16 The indices "are not intended to supplant the physician in the diagnosing of malnutrition. Rather, they furnish the physician with more adequate evidence for his diagnosis than he has had in the past. Using these indices, in conjunction with other clinical signs, the physician can diagnose the condition and prescribe what shall be done." 17

The score card for Nutritional Status Indices shows the steps necessary for the calculation of the three Nutritional Status Indices. The computations for the weight index may be found on page 16 . The procedures for evaluating the other two-namely, the child's arm girth and subcutancous tissue-are not described because they involve similar calculations.

\footnotetext{
15 Defective nutrition is defined by Franzen and bis coworkers as "a low amount of arm girth, subcutaneous tissue and weight, each for skeletal build. Our definition is specific, but it represents a condition which includes many other subjective signs." See Appendix I1: (88) Physical Defects; the pathway to correction, p. 63 .

In 1935 Mitchell, who was also associated with this group, added: "These measurements compared with a random 1,000 children of the same skeletal build are not in themselves an evaluation of nutritional status, but they do give reliable, objective, and valid distinetions in weight, musculature, and adiposity which are significant in such an appraisal. They are indices of physical signs which should be properly evaluated in a composite of signs and symptoms. Of course, deviations from an average should not be interpreted directly as desirable and undesirable signs, but the average provides a convenient reference point which gives definiteness to the measurements. The use of aceurate distinctions in these three physical signs releases the clinician from the difficulties of individual judgment and gives him greater freedom to apply all the subtleties of the art of medicine in judging function, growth, and development and all the intricate factors involved in the nutritional process." See Appendix II: (71) Mitehell, p. 319.

16 See Appendix I1: (75) Nutritional Status Indices, p. 2.

17 See Appendix 11: Ihid., p. 5.
} 
SCORE CARD FOR NUTIITIONAL STATUS INDICES I

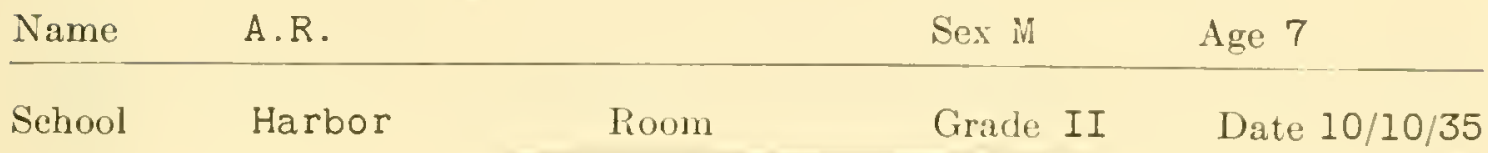

\section{MEASUREMENTS}

Arun Girth

Subeutaneous Tissue over the Biceps

Weight

Height

Chest Breadth

Chest Depth

Width of Hips

$\begin{array}{ll}\text { Flexed } & \text { a } \frac{18.4}{16.6} \\ \text { Relaxed } & \text { b } \frac{16.5}{10.5} \\ & \text { d } 10.5\end{array}$

g 46.0

h 44.0

$\mathrm{i}$

j 18.5

$\mathrm{k}$

Inspiration

Expiration

Inspiration

1

m 14.5 n 28.2

20.4

COMPUTATION OF INDICES

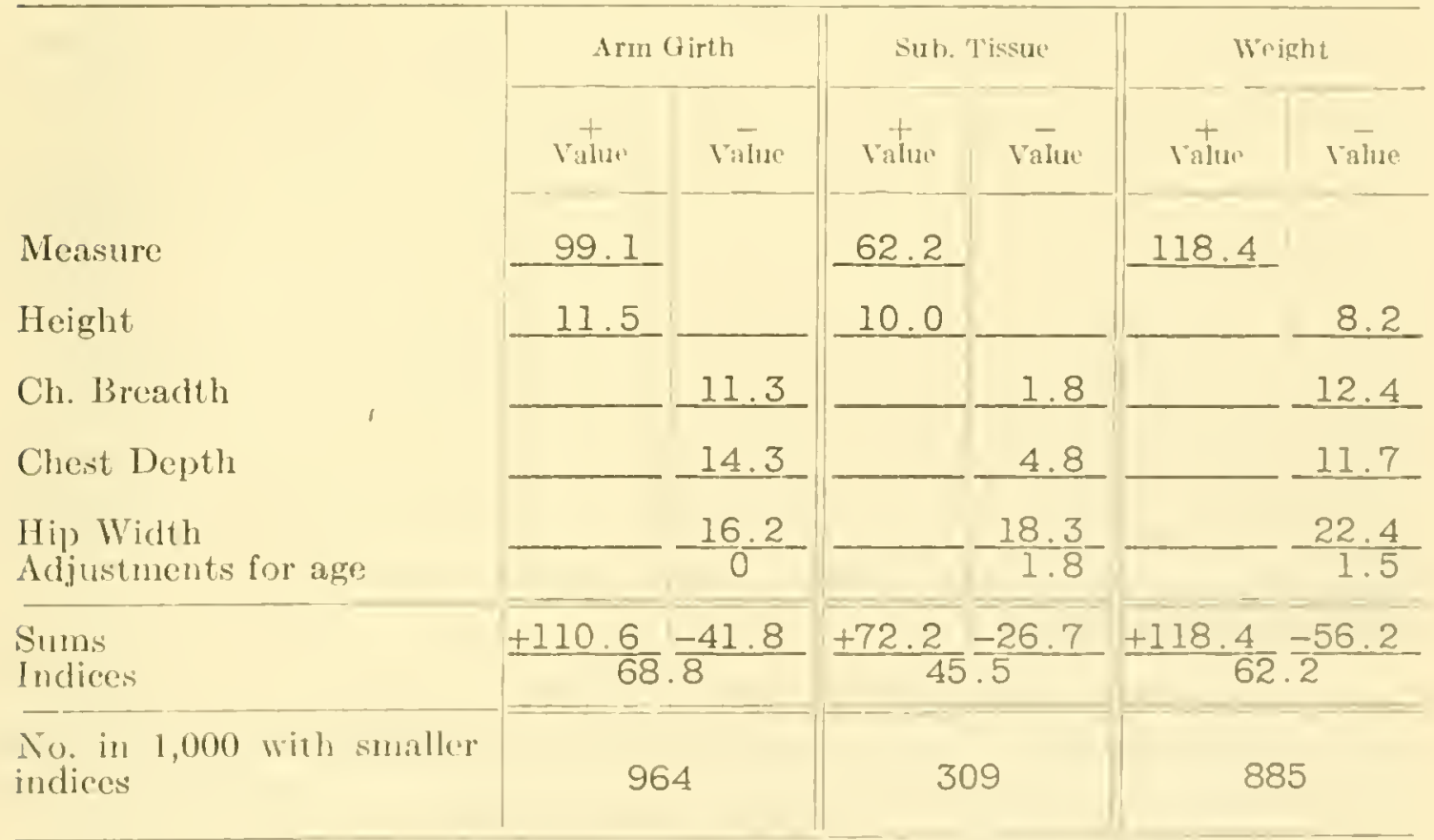

1 This form is presented in (75) Nutritional status Indices. p. I5 (sec Alpeudix II). 
The detailed steps in the determination of this weight index for the Italian boy, A. R., are presented at this point. The exact wording used in the instructions given in the monograph, Nutritional Status Indices, has been followed as closely as possible.

a. Look up A. R.'s weight under Weight Reading in Table C for 7- to 9-year-old boys (see p. 24 of the monograph, Nutritional Status Indices) 18 and record the eorresponding table value on the line opposite "Measure" on the score card (score card for Nutritional Status Indices) in the plus (t) column under "Weight." The table value for A. R.'s weight of $46.0 \mathrm{lb}$. is 118.4 .

b. Look up his height under Height Reading in Table D, p. 25. Opposite the reading are three values. Select the one for weight and record this value in the line opposite "Height" in the section under the proper heading on the score card. Since the value is negative it is to be entered in the minus $(-)$ column. A. R.'s height was $44.0 \mathrm{in}$., which has the following table value for weight: -8.2 .

c. Look up his chest-breadth measurement in Table E, p. 26. Record on the score card the table value given for weight and enter this value opposite "Chest Breadth" under the proper index heading in the column with the appropriate sign. A. R.'s chest breadth of $36.4 \mathrm{~cm}$. has a table value for weight of -12.4 . Since this is a negative value, enter it in the negative colımn.

d. Similarly, obtain the values for his chest depth, Table F, p. 27, and for hip width, Table G, p. 28. The table values for A. R. are written on his score eard (score eard for Nutritional Status Indices).

e. Look up his age in Table H. Since A. R. is a 7-year-old boy, 7 but not 8 , the table value for his age to be used for his weight-index ealculation is -1.5 . Enter this value on the line opposite "Adjustments for Age" under the proper index heading in the column with the appropriate sign.

$f$. Add the figures in the plus column for the weight index and record the total in the plus column on the line opposite "Sums." Likewise, add the figures in the minus column and record the total in the minus column on the line opposite "Sums." These two sums for A. R.'s weight index are +118.4 and -56.2.

g. Subtract the sum of the values in the negative eolumn (56.2) from the sum of the values in the positive column (118.4) and record the difference (62.2) in the line opposite "Indices." 'This score, 62.2, is A. R.'s nutritional index for weight and is strictly comparable with his indices for arm girth and subeutaneous tissue. By referring this score or index to Table $\mathrm{X}$ of the monograph, Nutritional Status Indices, p. $65, \mathrm{~A}$. R.'s standing in weiglt relative to others like him in skeletal build may be obtained. Using Table X, look up 62.2, A. R.'s weight score. The table value opposite this is 885 , the number in 1,000 children of the same sex, age, and skcletal build who have sinaller weight indices (scores) than A. R. In other words, among a general sampling of 1,000 boys of the same age and skeletal build, 885 in 1,000 weigh less than $\mathrm{A}$. R..$^{19}$

In order to facilitate comparisons with the other indices included in this study, 'Table $\mathrm{X}$ of the monograph, Nutritional Status Indices, has been modified to show the number of children in 100, instead of in 1,000, having less than a given score in one of the Nutritional Status Indices. When this revised form of Table $\mathrm{X}$ is used 88 (S8.5) boys in 100 of the same age and skcletal build weigh less than A. R.

19. Sce Appendix II: Ihid., 1). 24.

10 This description of the methol of computing the Nutritional status Index for Weight is based on the illustration giren on pp. 14-18 of the monograph, Nutritional Status Indices. Sce Appendix II: (75). 


\section{THE PRYOR WIDTH-WEIGHT 'TABLES}

The Pryor Tables estimate the average weight of a boy or girl of a given age (at nearest birthday) and body build, jurlged in tarms of his or her height (to the nearest inch) and bi-iliac diameter.

The calculation of this index also may be illustrated for the Italian boy, A. R.: According to the sample schedule of physical mosurements (see p. 11), when A. R. was 7 years old his height was $44 \mathrm{in}$., his weight was $46 \mathrm{lb}$., and "the width of his iliac crest" was $20.2 \mathrm{~cm} .{ }^{20}$ As the Pryor 'Table for 7 -year-old boys does not give the expected ol" average weight for a boy who is $44 \mathrm{in}$. tall and has a crest measurement of $20.2 \mathrm{~cm}$, it is necessary to approximate A. R.'s expected weight. The following method is used: The table gives the average weight, $42 \mathrm{lb}$., for a boy of the same height as $\mathrm{A}$. R., who has a bi-iliac diameter of $19.3 \mathrm{~cm}$. (0.9 cm. less than A. R.'s). It also gives the expected weight, $46 \mathrm{lb}$., for a boy of the same height who has a diameter of $21.5 \mathrm{~cm}$. In other words, an increase of $2.2 \mathrm{~cm} .(21.5 \mathrm{~cm}$. $-19.3 \mathrm{~cm}$.) in the width of the iliac crest-to usc one of Pryor's terms - corresponds to an increase of $4 \mathrm{lb}$. in the average weight of a boy of this age and height. A. R.'s crest measurement is $0.9 \mathrm{~cm}$. larger than the smaller of these two diameters given in the table and corresponds approximately to a weight increase of $1.6 \mathrm{lb}$., which is added to the average weight, $42 \mathrm{lb}$, of a boy with a bi-iliac diameter of $19.3 \mathrm{~cm}$, giving an expected weight of $43.6 \mathrm{lb}$. for a child who was weighed with his clothing removed. As the boys and girls included in this study were weighed wearing their clothing, an allownce of 2 lb. for the weight of the clothing must be made for children who are more than $40 \mathrm{in}$. tall. ${ }^{21}$ Therefore, a 7 -yealr-old boy with the same height and crest measurements as $A$. R. weighs, on the average, 45.6 lb. (43.6 lb. +2 lb.), compared to A. R., who weighed 46 lb. In other words, according to this index, A. R. wals $0.4 \mathrm{lb}$. overweight (46-45.6). As the Pryor Tables do not define the annount of variation in weight which is within normal limits nor the child's relative standing in weight, a procedure las been developed which is comparable to Table $\mathrm{X}^{22}$ in the monograph, Nutritional Status Indices. ${ }^{23}$ It gire's the number in 100 children of the sime sex, age, and body build who weigh less than any individual child. When this mothod of senering is used, 54 boys in 100 of the sime sex and huild weigh less than A. R.

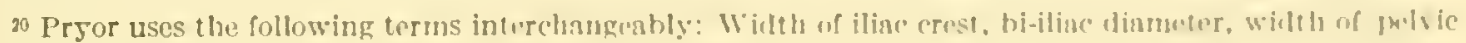
erest, bicristal diameter, and willh of crost of ilimm.

21 See Appendix 1I: (8f) Pryor, p. 11.

${ }_{22}^{2}$ See Appendix 11: ( 75 ) Nutritional status Indicus, P. 6.5.

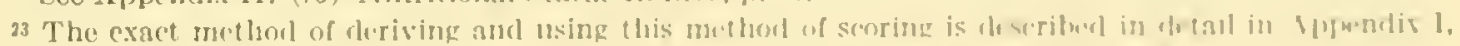

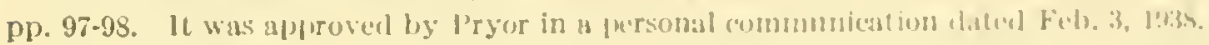




\section{Limitations of the Four Indices of Body Build}

In outlining the limitations of measuring the child's fitness in terms of his body build, certain questions which refer either direotly or indirectly to the four indices ineluded in this study have been omitted intentionally from the discussion. For example, Wilkins in an artiele entitled "The Assessment of Nutrition in Sehool Children," which appeared in The Medical Officer in 1937, points out a "subtle error" in the standard based on the relation of weight to height; namely, that "the well-nourished child, while both taller and heavier than the poorly nourished, is at the same time lighter in relation to its height than the less well-nourished. In other words, the less well-nourished child is often heavier in relation to its height than is the betternourished child. This disturbance of the natural relation of weight to height is, of course, the result of faulty nutrition affecting growth over a considerable period." 24

Various workers have also raised questions concerning some of the measurements used for the Nutritional Status Indices. For example: Is the amount of subcutaneous tissue which can be picked up associated with the size of the finger tips? Can one pick up two layers of the skin of a very fat child, with the ealipers set at 30 to standardize the size of the bite? ${ }^{25}$ Are the fat and muscle of the upper arm representative of the subcutaneous tissue and musculature of the entire body?

Many other questions arise which one would like to study. For example: To what extent is an index prognostic as well as diagnostic? What happens to an index during an acute illness? Is an index related to a child's gain in weight or to some other measure of his growth and development?

\footnotetext{
24 See Appendix 1I: (121) Wilkins, p. 146.

${ }_{25}$ The measurements "are taken with the special subcutaneous-tissue ealiper. The examiner stands to the right of the child and measures the bare right upper arm.

"Ask the child to extend the bared right arm at right angles to the side of the body, and then to flex the arm and 'make a muscle.' Mark with a pencil the highest point on the biceps muscle. Then have the child relax and lower his arm. (This highest point on the biceps musele is the same level at which the girth of the upper arm is measured and, in aetual practice, is marked at the same time the arm-girth measurements are taken.) 'Through this 'biecps point' draw a short hinc across the arm. This line furnishes a referenec point for taking the measurements.

"The size of the 'bite, or the amount of tissue that is grasped, has eonsiderable influenee on the accuracy of this measurement. In order to standardiz. the nmomt of tissue grasped, the size of the 'bite' is determined by the caliper itself. Take the ealiper in the right hand and open it to a reneling of 30 . Then, using the 'biergs point' as a center, straddle the blades of the ealiper, eqnally on each sicle of the 'biceps point,' with the lower cdges of the blades touching on the horizontal line which has been drawn on the arm. With the left hand above the caliper, place the index finger and the flumb of the left haud in eontact wit li the onter surface of the caliper blades, remove the caliper, and pineh up the amount of tissue indicuted, thus frecing the tissue from the undrolying museulature. Place the blades of the enliper as elosely below the index finger and thumb as jossible, release the hlades, and measure the thickness of the subeutnneous tissue. liceord the caliper roarling.

"The second measurement is taken in cxactly the samo way as the first, cxecpt that to locato the position of the index finger and the thumb the caliper blates are placed with the nuper celges, ruther than the lower edges, touching on the line. The sum of the two realings is the Subeutaneous-'Tissue measurcment." See Apleudix 1I: (75) Nutritionnl Statis 1ndiees, [p. 8-10.
} 
The importance of all these problems is fully recognized, but, on the other hand, they are necessarily subordinate to the question with which this study is concerned; namely, do any or all of these indices satisfactorily measure physical fitness? Warner $(1935)^{26}$ has summarized the eriteria which such an inder should possess in this manner: Any satisfactory index of nutritional status (1) must correlate to a high degree with a clinically acceptable definition of nutrition; (2) must be objectively determinable; and, finally (3) must be relatively simple and applicable to the ordinary school health program, and of such a character that it might be used by persons with only a moderate amount of training and technical skill.2i

The indices included in this study were, of course, designed to select the child (of a given sex and age) who is physically unfit only insofar as physical fitness is related to and can be measured by certain abnormalities of physique. The Baldwin-Wood and Pryor Tables were developed to identify a boy or girl who is underweight for his or her body build, ${ }^{28}$ judged in terms of height or height and bi-iliac diameter; the Nutritional Status Indices, to identify one who is below his skeletal peers (children of the same height, chest breadth, chest depth, and hip wirlth) in subcutaneous tissue, arm girth, or weight; and the $\mathrm{ACH}$ Index, to identify the child who has a small amount of soft tissue in relation to his build. Therefore, the association between a deficiency in any one of these measures and the child's physical fitness determines the extent to which any of these indices may be expected to identify the child who is physically unfit.

\section{Previous Studies}

A considerable literature is concerned with this subject-the efficieney of each of these four indiees in identifying children who are physically unfit. It may be classified conveniently under two headings: (1) Studies in which the indices have been applied to children belonging to another race, to children of a diflerent chronological age, or to children living in widely separated geographic regrions; and (2) studies in which the children are more or less comparable to the 7 -year-old white boys and girls living in New Ilaven, Comm., obserations of whom form the basis of this report.

Under the first heading are included such studies as those of Ayroyd and Rajagopal (4), who tested the ACH Index on a group of chitdeen in South India; Franzen (39) (19:34), who studied the AC'll Index, the Baldwin-Wood 'Tables, and an index of weight for height and hip width on a croup of 11 -yeall-old boys and grirk; L L Riche (5.5), who

20 see Appendix 11: (117) Warmer, 1. 19.

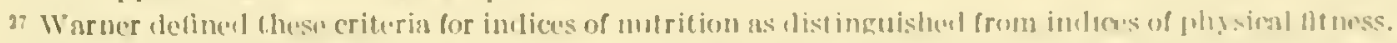

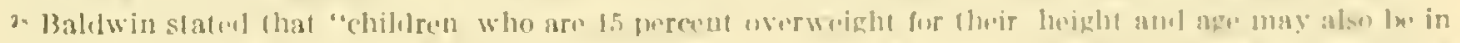

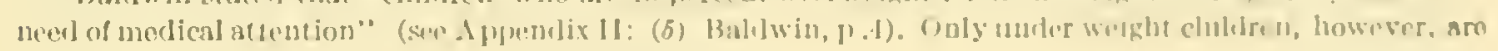
being considered in this report, ns is indicatul on $\mathrm{p} .10$. 
applied the $\mathrm{ACH}$ Index to children living in Pretoria, South Africa; Jones (51), who tested several indices, including Pryor's Tables, on a group of English school boys; and Steggerda and Densen (108), who applied the Baldwin-Wood standard to Navaho Indian children and to children of Dutch descent. ${ }^{29}$

It is unnecessary to review such studies, for the suceess or faiture of an index applied to ehildren of another race or age or those living in different geographic regions has no direct bearing on the effectiveness of an index to identify 7-year-old white children living in New Haven, Comn.. who may be in need of medical care or nutritional advice and assistance.

On the other hand, it is important to know whether other investigators have found a given index a satisfactory method of assessment when applied to children who are more comparable to those included in this study. Only a few studies come under this heading:

Clark and his associates (22) tested the Baldwin-Wood Index in 1924 on a group of 506 native white children, ${ }^{30}$ aged from 6 to 18 years, inclusive (at nearest birthday), including 327 -year-old boys and girls. All these children were without physical defects or evidences of disease and were judged to be in good or excellent nutritional condition. ${ }^{31}$ Their findings for 7 -year-old boys and girls are given in the following table:

Nutrition: Good or Excellent ${ }^{1}$

Percentage deviation from the Baldwin-Wood standard

Number of 7 -year-old children who are a given per cent above or below the Baldwin-lrood standard weight

\begin{tabular}{l|r|r} 
& Boys & Girls \\
\hline 16 to 20 percent underweight & 1 & 1 \\
11 to 15 percent underweight & 3 & 4 \\
6 to 10 pereent underweight & 5 \\
1 to 5 percent underweight & 1 & 6 \\
0 to 5 percent overweight & 2 \\
6 to 10 pereent overweight. & 1 \\
11 to 15 percent overweight & 1 \\
16 percent or more overweight & 14 \\
\hline
\end{tabular}

1 This table is adapted from table IV of the report diseussed which includes figures for ehildren from 6 to 18 years of age, inclusive. Only findings for 7 -year-old boys and girls have been used here. See Appendix II: (22) Clark, Sydenstricker, and Collins, p. 523.

20 See also Appendix 1I: (1) Allman, who applied the 13aldwin-Wood and ACH Indiees; (2) Aykroyd, (3) Aykroyd, Madhava, and Rajagopal, (16) Buck, (18) Chatterji, (62) MePherson, (84) l'inckney, reference to Clements and Leipolit in (99) Seantlebury, (122) Wilson, Ahmad, and Mitra, (12.3) Wilson and Mitra, who used the ACH Index; (70) and (72) Mitchell, (101) Selulutz, who employed the Nutritional Status Indiees; (112) and (113) Turner, for studies using the Baldwin-Wood Tables; (150) 7ayaz ct al., for an applieation of the Pryor and Baldwln-Wood Tables; and (98) Snyler, St. Paul, Minn., who used the l'ryor Tables.

30 Both the parents and the grandparents of these ehildren were born in the United States. A more detailed description of the group is given in a study by the same authors entitled "Indices of Nutrition." These 506 chilelren lived in 4 States: FIorida, 130; Croorgin, 159; Tennessee, 110; and Utah, 107. There is no inclication as to whether they lived in rural or urban areas. See Appendix I1: (21) Clark, Sydenstrieker, and Collins, pl). 1214-1215.

31 A 5-point sculc ("recrlent," "good," "fuir," "poor," or "very poor") was used by the pliysieinns for grading nutrition cvaluated in terms of general apumarane, activity, eondition of the skin, amount of subcutaneous fat, musele tone, alertness, and vitality. See Apueudix 1I: (21) Clark, Sjdenstricker, and Collins, np. 1244-1215. 
It may be seen from this table that 5 of the 14 7-year-old boys (36 pereent) and 6 of the 187 -year-old girls (33 percent), all of whom were elinically in good or excellent condition, were 6 or more percent underweight according to the Baldwin-Wood standard. Although these results are based on only a small number of children, they naturally throw some doubt on the Baldwin-Wood method of assessment. $^{32}$

In discussing the significance of their findings Clark and his associates point out three possible sourees of error in the Baldwin-Wood Tables: (1) They may be based on an unrepresentative group of children; (2) the limits for normal variation (10 percent) in a child's actual weight compared with his expected weight may be too narrow; these limits may vary with sex or age; ${ }^{33}$ and, finally, (3) a deriation from an average weight for sex, height, and age may be an unsatisfactory criterion of physical fitness. ${ }^{3+}$

In 1924 Dublin and Gebhart applied the Baldwin-Wood Tables ${ }^{35}$ to a group of 4,047 first-generation Italian children aged from 2 to 10 years, inclusive (age at nearest birthday), living in the Mulberry District of New York City. These boys and girls were the apparently well children coming under the care of the Association for Improving the Condition of the Poor. They were examined by one well-trained pediatrician and were diagnosed as either well-nourished or undernourished. The authors state:

The doctor's diagnosis of defective nutrition was based on the picture of the whole child and not on the weight and lieight alone. Such items as the state of the musculature, the huster of the eves, the color and bearing of the children, their posture, and the relative amount of subertaneous tissne were all taken into aecount in assessing the child's mutrition. In addition, the physical measurements of height and weight were given careful consideration in relation to the child's age. ${ }^{36}$

The aceompanying table shows the agreement between the Baldwin-Wood standard and the physician's judgment, for the 4557 -yearold children included in the study. In this table a 7 -pereent limit for underweight has been used. In other words, if the diflerence between the child's observed and his expected weight is less than 7 percent of his expeeted weight he is not identified by the Baldwin-

${ }^{32}$ Although the authors recogniz. the fact that no satisfnctory standard of physleal ntenes sheult inclule any large proportion of group which, judecel by careful medical examination, is found io be in 111 health. they did not study this important aspect of the problen. Ser Aynendix II: (20, clark, sydenstricker. and Collins, 1.519.

${ }^{33}$ It is interesting to note that Faber (1925) questioned the valility of ballwin's standards (1921), as wall

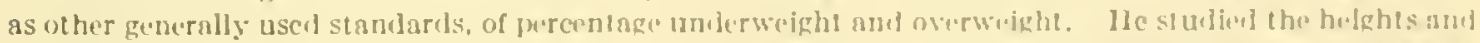

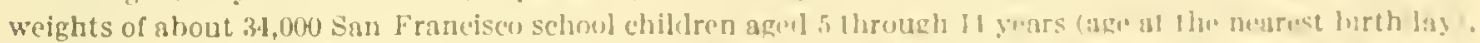

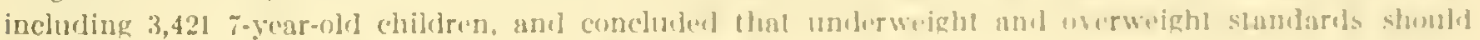
vary with sex and age. Sne Aprendix 1I: (31) Fabur.

34 See Appendix I]: (22) Clark, Syloustrickur, aml ("ollins, 1). 521.

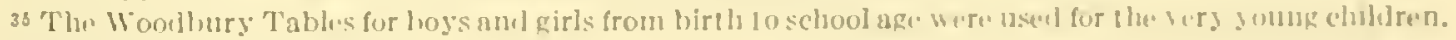
Sec Appondix 11: (125) Wunllury.

${ }^{30}$ Sce Appondix II: (28) Dublin and Gubhart, p. 4. 
Wood standard as being underweight. For example, there were 77 7 -year-old boys who, according to the physician's judgment, were undernourished. The Baldwin-Wood Tables failed to identify 52 (67.5 percent) of these 77 children as underweight. In other words, using a 7 -percent limit for percentage underweight, the tables selected only 32.5 percent of the boys whom the physician had diagnosed as undernourished.

A Comparison of the Selection Made by the Physician's Diagnosis of Nutrition and by the Use of the Baldwin-Wood Tables ${ }^{1}$

BOYS

WELL-NOURISHED

$\begin{array}{ccc}\text { Age }^{4} & \begin{array}{c}\text { Doctor's } \\ \text { diagnosis }\end{array} & \begin{array}{c}\text { Weight table } \\ 7 \text { percent } \\ \text { limit }{ }^{2}\end{array} \\ 7 \ldots \ldots \ldots & 137 & 130\end{array}$

WELL-NOURISHED

Age ${ }^{4} \begin{array}{r}\text { Doctor's } \\ \text { diagnosis }\end{array}$

7
Weight table

7 percent 134

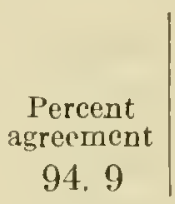

GIRIS
UNDERNOURISHED

$\begin{array}{cc}\begin{array}{c}\text { Weight table } \\ 7 \text { percent } \\ \text { limit }{ }^{3}\end{array} & \begin{array}{c}\text { Percent } \\ \text { agreement }\end{array} \\ 25 & 32.5\end{array}$

\section{UNDERNOURISHED}

$\begin{array}{cc}\text { Weight table } & \\ 7 \text { percent } & \text { Percent } \\ \text { limit }^{3} & \text { agreement } \\ 25 & 25.3\end{array}$

1 Adapted from table 1, D. 5, in Dublin and Gebhart (28) (Sec Appendix II).

$2 \mathrm{~A}$ child is identified as well-nourished if he is less than 7 percent underweight or if his observed weight is more than his expected weight.

${ }^{3} \mathrm{~A}$ child is selected as undernourished if he is 7 percent or more underweight according to the standard.

4 Age at nearest birthday.

In discussing these results Dublin and Gebhart conclude: "A method which misses three-fourths ${ }^{37}$ of all of the children whom a competent physician, after a thorough examination, would call undernourished has certainly scant value even as a 'rough index for' sorting out the most needy cases." " They attribute the failure of the index in part to the fact that "these Italian children are heavier for each inch of height than the children used in the Wood-Baldwin-IVoodbury Table." 38

In Mitchell's study (1935) the Baldwin-Wood Tables and the Nutritional Status Indices were applied to only eight children, including two 7-year-old boys, ${ }^{39}$ James and Edward, who had been referred by their teachers to a physician for special examinations.

James weighed $43 \mathrm{lb}$. and was, according to the investigator, obviously undernourished. He was so unusually low in weight, musculature, and adiposity that he appeared thin and frail and suggested poor nutrition to the casual observer. The clinical examination also showed very little flesh over the chest, well-defined winged scapulae, and soft, flabby muscles. According to the Baldwin-Wood Tables

${ }^{37}$ 'The tables failed to identify three-fourths of the children of all ages (2-10 years, inelusive); two-thirds of the 7-ycar-old boys and threc-fourths of the $7-y$ ear-olel girls.

38 Sec Appenrlix II: (28) l Jublin and Gehlart, I). \&.

${ }^{39}$ No statement is given as to how age was defined, nor an inclicntion of the race, or the location of the homes of these children. 
he should have weighed $50 \mathrm{lb}$. and was, therefore, 14 pereent underweight. In terms of the Nutritional Status Indices only 2 in 100 boys with the same skeletal build weigh less than James; 6 have a smaller arm girth and 20 in 100 have less subcutaneous tissue. ${ }^{40}$

Edward weighed $47 \frac{1}{2} \mathrm{lb}$. 'The investigator described him as of about average height with average chest breadth and a shallow chest and narrow hips. Both arms and legs appeared very thin and his muscles were very soft and flabby. The child was one of nine children; the family was entirely dependent on public relief; investigation showed a diet of exeess starehy foods which may have accounted for his adipose tissue. During 6 months' observation he gained only $3 / 2$ lb. ${ }^{41}$ According to the Baldwin-Wood Tables he was 10.4 percent underweight. In terms of the Nutritional Status Indices, 7 bors in 100 with the same skeletal build have a lower weight; 9, a smaller arm girth; and 50, a smaller amount of subeutaneous tissue.

To summarize: The Baldwin-Wood Tables identify both James and Edward as markedly underweight. Aceording to the Nutritional Status Indices also, both these children were underweight; they had exceptionally sunall arm girths; and James had a deficiency in subcutaneous tissue as well. These findings indicate that the Nutritional Status Indices may be more useful than the Baldwin-Wood Tables because they evaluate not only the child's weight but also his museulature and subcutaneous tissue. It should be pointed out, however, that Mitchell tested the indices on only a small number of children, and there is no evidence in this study to indicate that the Nutritional Status Indices will identify other children who are poorly nourished.

It is difficult to evaluate and compare these three studies for five reasons: (1) The indices were applied to groups of children living under varying conditions; (2) clinical judgment of nutrition was made by diflerent physicians; (3) there was no attempt to craluate the objectivity and stability of clinical judgment nor the accuracy of the anthropometric measurements; (4) in one study (Clark ct al., 1924) the indices were tested only on children who were clinically in grood or excellent nutritional condition, in another (Mitchell, 1935), on children who had been referred by their teacher to the school physician for special examination, in the third (Dublin and (iebhart, 1924), on boys and girls whom the physician judged to be either well or poorly nourished; and (5) different selection points were used for testing the same index.

For example, Clark applied the Baldwin-Wood Tables to children in excellent or good nutritional condition and, using 6 percent as a limit for underweight, grouped the children by 5-pereent differences 
in the index. Dublin and Gebhart, on the other hand, applied both 7 and 10 percent or more underweight as criteria for selection, classified the children in only two groups, those who were identified as underweight and those who were not.

Probably a more satisfactory method of testing and comparing such indices is to apply them to a group of children belonging to the same nationality, of a given sex and age, and living in one community, who have been under observation for a sufficient period to permit evaluation of their physical well-being and their socioeconomic status, and then to compare the effectiveness of each of the indices in selecting those children who, in terms of cach of several carefully defined criteria, are likely to be in need of medical attention or nutritional advice and assistance.

The importance of such a study was pointed out by Jones in his monograph entitled "Physical Indices and Clinical Assessment of the Nutrition of School Children," in which he writes:

Hundreds of phrsical indiees of nutrition have been proposed by writers in many languages, but it is difficult to discover precisely what these indices will perform in practiee. Though there is an cnomous literature, there is no agreement among writers as to which index is best. General elaims coneerning the value of an index are met more frequently than precise details of performanee, and few attempts lave been made to test different indices on the same large group of children. ${ }^{43}$

The observations made of the children included in the present study may be used to test the indices in this way and to evaluate other methods of assessment, particularly the clinical examination. How accurate is the physician's judgment of the child's general nutritional status? Is it stable? Is his assessment of the child's nutrition in agreement with the judgment of other physicians? To repeat: This investigation of the phrsical fitness of New Haven children mar be used to measure the relative efficieney of sereral methods of assessing the physical fitness of 7 -year-old school children.

13 This term is used to distinguish hroad. ethnic groups.

13 See 1 ppendix 1I: (51) Jones, pp. :2-3. 


\section{Material and Methods}

The observations were made of 713 7-year-old whits children ${ }^{2}$ (365 boys and 348 girls) attending the kindergarten, first grade, or second grade of the public or parochial schools of New Haven, Conn., from September 1934 through May 1936. Of these 713 children 661 (92.7 percent) attended 44 of the 49 public grade schools in $\mathrm{N}$ (ow Haven; ${ }^{3} 52$ (7.3 pereent) of the boys and girls were enrolled in 4 of the 9 parochial schools. ${ }^{4}$

Each of these children may be briefly describerl as follows:

Race............
Sex
Age (in completed years at
$\quad$ first physical exarnination
$\quad$ in 1934)

Residence

School attendance

Period of observation
White.

Male or fernale.

Italian, Anerican, or other."

Six years (only a child who was a single legitimate birth and was born during the period from July 1 to December 31 , 1928, was eligible for inclusion).

Living with his family or in a foster home.

Attenrling a public or parochial school in 1928, inclusive, New Haven.

A minimum period of 12 consecutive months during the school years 1934-35 and 193536. (Most of the ehildren were observed for either 19 or 20 months.) ${ }^{7}$

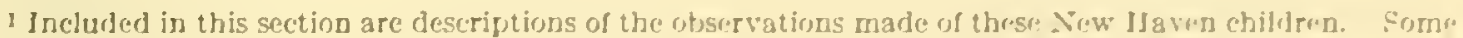
of these rata will form thro t)asis for additional sturdirs of child growth and drvolojement.

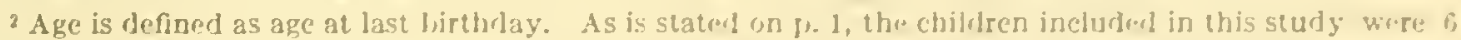
years old when the arst medical rexamination was marle. Jeriodic weighings wore tnallo of some of theso chlldren before they were f years old, the age at thw first wojghing ravging from 5 yetrs b menths to 6 gwar: 6 months. This rejort is based on observations marle when thro boys and girls wer. 7 yorat of ag", amplifked and interpreter] in relation to the "ardi"r firdiags.

Only children who were singlr., legitimate hirths, who were born during the period from Julg. I to Jecm

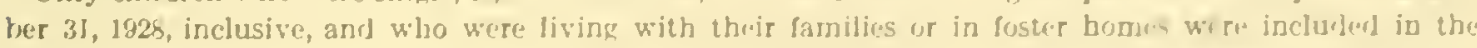
sturiy.

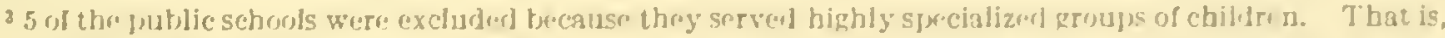

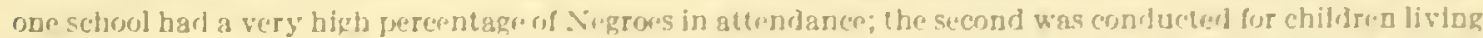

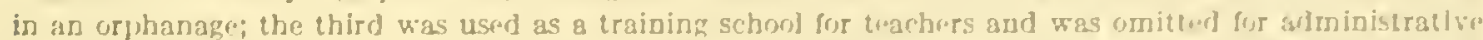
reasens; the fourth had only; a small enrollment of f-year-rild children; the fifth was a s[x-cial school for mintal defectives.

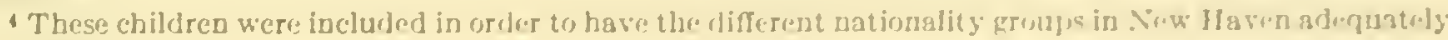
represented.

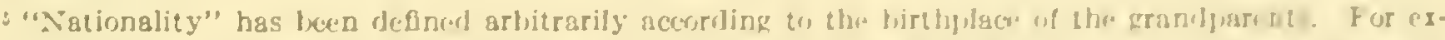

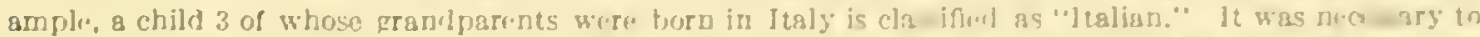

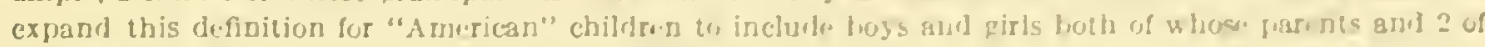
whose grandparents were born in the Uniters States.

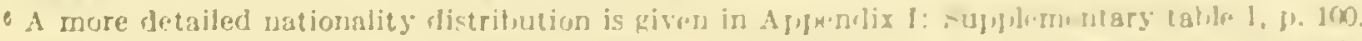

7 Atrout 5 f percent of the childred were observer] for 19 months and aboust 40 promt for ar months.
} 
The following observations were made of the child during this 19or 20-month period of observation:

\section{Physical examinations:}

He was given two ammual physical examinations by one pediatrician. The first examination was made when the child was 6 years old; the second, 1 year later. ${ }^{8}$ When the first examination was made, most of the child's clothing above the waist was removed; at the second examination, written permission had been obtained from the parents to remove all the clothing above the waist.

\section{Anthropometric measurements :}

He was measured at the same time the annual physical examinations mere made by one observer trained in anthroponetry. ${ }^{9}$

\section{Periodic weighings :}

The number of weighings varied: The minimum number was five; the maximum, nine; the average, eight. The ehild's age at the first weighing ranged from 5 years $S$ months to 6 years 6 months; at the last weighing, from 7 years 2 months to 7 years 10 months. His weight was taken at the time each of the anmual physical examinations was made; 6 months after the first examination; and at 4-month intervals ${ }^{10}$ during the school years $1934-35$ and $1935-36 .{ }^{11}$

\section{Information was also obtained concerning the following items:}

\section{Socioeconomic status:}

An eeonomic analyst ${ }^{12}$ visited his home during each of the 2 sehool years (1934-35 and 1935-36) and obtained information from his mother (or some other responsible adult member of the family if the mother was absent) eoncerning the child's general disease history, his dietary habits (particularly his consumption of milk and leafy vegetables), and the eeonomic status of the family. These visits were usually made within a period 2 to 3 weeks after the physical cxaminations.

\section{Schooling :}

Information concerning school absences-namely, the date, duration, and reason for each absence of 3 or more days' duration-was obtained from the school nurses' files. ${ }^{13}$

School progress was also recorded as "passed" or "failed."

\section{These 713 white children form a selected group. They were 6 years} old at the first physical examination, they were of single, legitimate

\footnotetext{
8 Thero was a minimum interval of 11 montls 16 days, and a maximum of 1 year 14 duys, betwen the 2 physical examinations.

- A few observations were male during the first year of the study by another trained observer who repeatedly ehecked her observations against those male by the anthropometrist.

10 'l'hese weighings were male for the most part during the last weeks of September 193.1; Jantary, May, and September, 1935; and January and May 1936.

"Tho weights were secured for the most part within a 3-day interval, and were taken by the anthropometrist, the pediatrician, and the office clerk. A fow weighings were also male by the economic analysts who collected the socioseonomic dinta.

12 The socioeconomic data were collected from Octoher throngh March or April of each fear of the study. 6 economic analysts were employed during the first year, and 2 mew agonts collected the data during the second sear of the study.

13 In the ease of absenees which oecurred prior to the sceond hom visit these data wore supplemented by information obtained from the mother at this visit. In appropriate instances additional incuiries wero made about absenees which occurred subsequently.
} 
birth, their nationality was known, they were living in their own or foster homes, they were attending school in New Haven, and most of them were under observation for a 19- or 20-month period.

Conversely, boys and girls were exchuded or discharged from the study for any of the following reasons: Multiple birth; illegitimacy; incorrect age; unknown or incorrectly stated race or nationality; residence in an orphanage or other institution; attendance at a private school (other than parochial) or nonenrollment at school; ${ }^{14}$ omission of certain anthropometric measurements or of either of the physical examinations; interval of more than 1 year and 14 days, or less than 11 months and 16 days between the two annual physical examinations; establishment of residence in another eity; death during the period of observation; or age outside limits established for testing the indices. ${ }^{15}$ It is, of course, difficult to estimate the effect of excluding these children from the study, and no attempt has been made to do so.

\section{A Description of the Boys and Girls Included in the Study}

A description of the age and nationality groups represented, the kind of homes the children came from, and the general physical condition of the 713 boys and girls included in the study may be helpful in interpreting the results.

\section{AGE}

The ages (in completed years and months) of the children when the second anmual physical examinations were made are given in table 1. None of these 713 boys and girls were less than 7 years 0 months of age. Approximately 72 percent were less than 7 years 4 months, and none of them were more than 7 years 7 months of age. In other words, there is relatirely very little variation in the ages of the boys and girls included in the study.

This somewhat munsual age distribution is probably the result of the following cincumstances: Only chiddren born during the period from July 1 to Decenber 31, 1928, inclusive, were cligible for inclusion; the anmul physieal examinations were made from October of one year through March of the next; and no child was retained in the study who was less than 6 years of age at the time of his first medical exammation or less than 7 years old at the second examination, which was made approximately 1 year later.

\footnotetext{
it 'There were 2 reasons for nonenrollment: (1) Childen were not requireel in attent srlionl untll they were 7 years of age; (2) they were physically ineapacitated and wnable to attend schuol.

${ }^{15} \Lambda t$ the beginning of the study, age was defned as age at nearest birthday. Later, it was clangeal to age at last birthdas in order to permit lesting of the Nutritional Status and A C'll I ndlers wil all the chilurnen included.
} 
TABLE 1.-Age of the boys and girls at the time of the second physical examination

\begin{tabular}{|c|c|c|c|c|c|c|}
\hline \multirow{2}{*}{ Agel } & \multicolumn{2}{|c|}{ Both sexes } & \multicolumn{2}{|c|}{ Boys } & \multicolumn{2}{|c|}{ Girls } \\
\hline & Number & Pereent & Number & Percent & Number & Percent \\
\hline Total & 713 & 100.0 & 365 & 100.0 & 348 & 100.0 \\
\hline $\begin{array}{l}7 \text { years } 0 \text { months... } \\
7 \text { years } 1 \text { mont } h . . . \\
7 \text { years } 2 \text { months... } \\
7 \text { years } 3 \text { months... } \\
7 \text { years } 4 \text { months... } \\
77 \text { years } 5 \text { months... } \\
7 \text { years } 6 \text { months... } \\
7 \text { years } 7 \text { months... }\end{array}$ & $\begin{array}{r}74 \\
151 \\
150 \\
137 \\
91 \\
70 \\
33 \\
7\end{array}$ & $\begin{array}{r}10.4 \\
21.2 \\
21.0 \\
19.2 \\
12.8 \\
9.8 \\
4.6 \\
1.0\end{array}$ & $\begin{array}{r}36 \\
78 \\
67 \\
74 \\
46 \\
39 \\
20 \\
5\end{array}$ & $\begin{array}{r}9.5 \\
21.4 \\
18.3 \\
20.3 \\
12.6 \\
10.7 \\
5.5 \\
1.4\end{array}$ & $\begin{array}{r}35 \\
73 \\
83 \\
63 \\
45 \\
31 \\
13 \\
2\end{array}$ & $\begin{array}{r}10.9 \\
21.0 \\
23.9 \\
18.1 \\
12.9 \\
8.9 \\
3.7 \\
.6\end{array}$ \\
\hline
\end{tabular}

1 Age is given in completed years and months.

\section{NATIONALITY}

The nationalities to which the children belong are shown in table 2. ${ }^{16}$ About 46 percent of the children were classified as "Italian" and approximately 18 percent as "American." The remaining 36 percent, representing various geographic groups, were clussified as "Russians," "Polish," "Irish," and "All others." The fact that so large a number of Italian children were included in the study is of particular significance because, on the average, the Italian boys and girls were shorter and tended to weigh less than the other children. ${ }^{17}$ Is this difference in their body build likely to affect the efficiency of the indices?

TABLE 2.-Nationality of the boys and girls

\begin{tabular}{|c|c|c|c|c|c|c|}
\hline \multirow{2}{*}{ Nationality } & \multicolumn{2}{|c|}{ Both sexes } & \multicolumn{2}{|c|}{ Boys } & \multicolumn{2}{|c|}{ Girls } \\
\hline & Number & Pereent & Number & Percent & Number & l'ercent \\
\hline Total & 713 & 100.0 & 365 & 100.0 & 345 & 100.0 \\
\hline 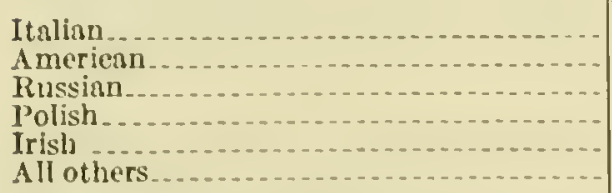 & $\begin{array}{r}330 \\
130 \\
66 \\
35 \\
34 \\
118\end{array}$ & $\begin{array}{r}46.3 \\
15.2 \\
9.3 \\
4.9 \\
4.8 \\
16.5\end{array}$ & $\begin{array}{r}166 \\
65 \\
34 \\
19 \\
17 \\
64\end{array}$ & $\begin{array}{r}45.5 \\
17.5 \\
9.3 \\
5.2 \\
4.7 \\
17.5\end{array}$ & $\begin{array}{r}164 \\
65 \\
32 \\
16 \\
17 \\
54\end{array}$ & $\begin{array}{r}47.1 \\
15.7 \\
9.2 \\
4.6 \\
4.9 \\
15.5\end{array}$ \\
\hline
\end{tabular}

1 Classifleation was based on the birthplace of 3 of the child's grandparents. The classifieation "Americau" includes not only children 3 of whose grandparents were born in the United States but also children whose parents and 2 of whose grandparents were born here.

\section{Location.}

\section{HOMES}

'The location of these children's homes is shown on the map on p. 29.

10 For the definition of "nationality" used in the study sew page 25.

17 Sec tahles 11 and 12, which give the heights and weights of the boys and girls belouging in each nationality gromp. Seo also Merodith's discussion of this problem: Appendix 11: (68) Mleredith, p. 344. 
The various sections of the city were all fairly well represented, but the majority (62.7 percent) of the boys and girls lived in the outlying regions, especially in the eastern (19.1 percent) and western (25.0 percent) parts of New Haven.

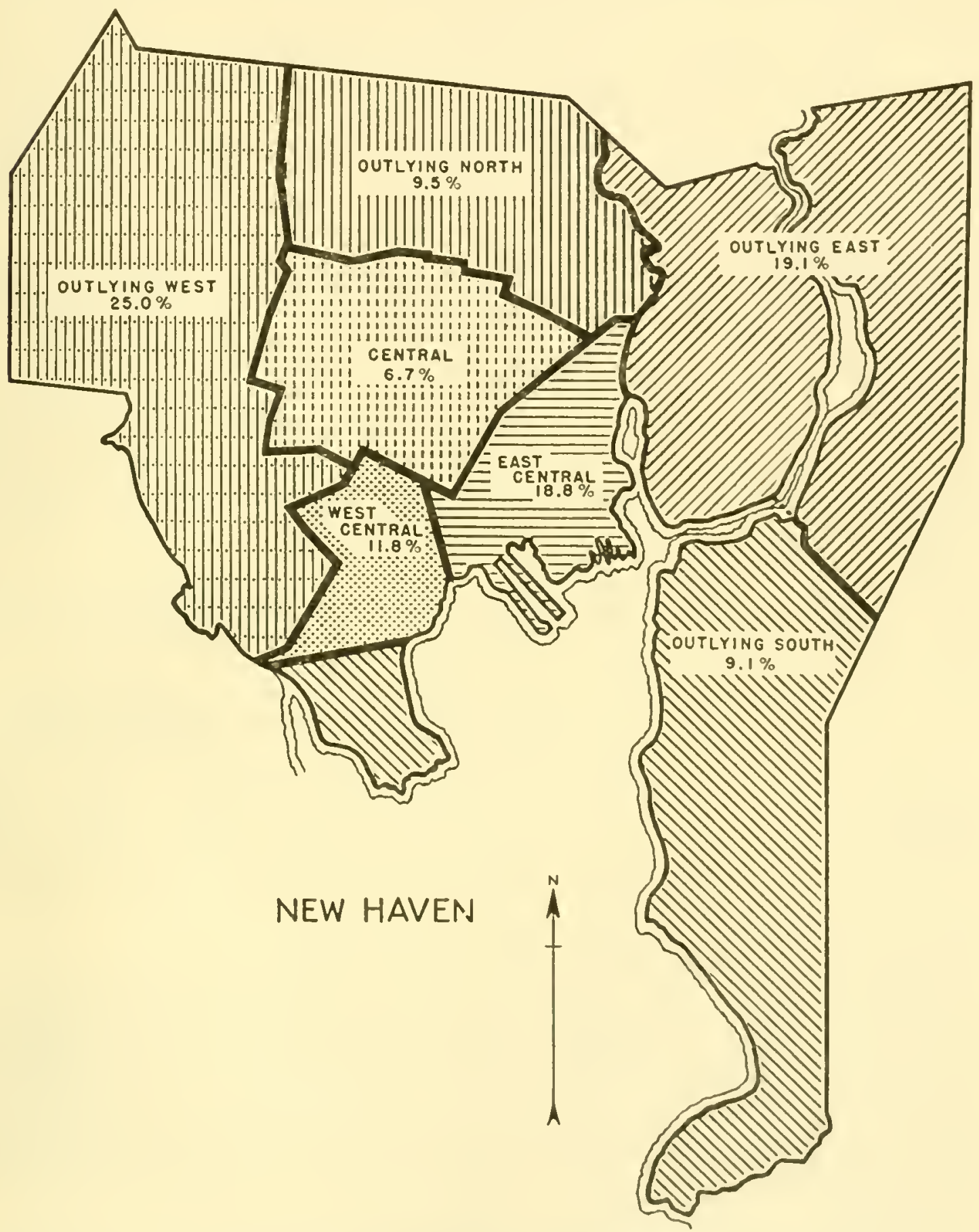

Location of the Homes of the Children

Type of duelling.

Only about 12 pereent of the boys and grits were living in one-family dwellings; all the others, approximately ss perecent, lived in flats or apartments. (Table 3.) The fact that so few of the children lived 
in one-family houses can be attributed in part to the relatively small number of such dwellings which exist in New Haven. ${ }^{18}$

TABLE 3.-Type of duelling occupied by the families of the boys and girls t

\begin{tabular}{|c|c|c|c|c|c|c|}
\hline \multirow{2}{*}{ Type of dwelling 2} & \multicolumn{2}{|c|}{ Both sexes } & \multicolumn{2}{|c|}{ Bors } & \multicolumn{2}{|c|}{ Girls } \\
\hline & Number & Percent & Sumber & Percent & Number & Percent \\
\hline Total & 3695 & 100.0 & 3355 & 100.0 & 337 & 100.0 \\
\hline $\begin{array}{l}\text { One-farnily dwelling - } \\
\text { Flat or apartment -. }\end{array}$ & sit & $\begin{array}{l}12.1 \\
\text { S. } 19\end{array}$ & $\begin{array}{r}37 \\
321\end{array}$ & $\begin{array}{l}10.3 \\
89.7\end{array}$ & $\begin{array}{r}47 \\
200\end{array}$ & $\begin{array}{l}13.9 \\
\text { S6. } 1\end{array}$ \\
\hline
\end{tabular}

1)ata based on observations made when thr children were 6 years of age.

: 1-family dwelling is a residenee adapted to the use of only i family. It may be connected with a store or it may be one of a series of houses with adjoining walls. A flat $\mathrm{nr}$ apartment is a 1-family unit in a building adanted to 2 or more families. These definitions are adapted from Appendix II: (26) Dreis, p.9.

3 Trpe of dwelling was unknown for i boys and 11 girls.

\section{Presence of parents in the home.}

Most of these children (90.3 percent) were residing with both their parents. Less than 10 pereent (9.0 percent) lived with only one parent; and very few boys and girls (0.7 percent) resided in foster homes. (Table 4.)

TABLE 4.-Presence of parents in the homes of the boys and girls

\begin{tabular}{|c|c|c|c|c|c|c|}
\hline \multirow{2}{*}{ Parents living in the home } & \multicolumn{2}{|c|}{ Both sexes } & \multicolumn{2}{|c|}{ Boys } & \multicolumn{2}{|c|}{ Girls } \\
\hline & Number & Pereent & Number & Percent & Xumber & Percent \\
\hline Total & 713 & 100.0 & 36.5 & 100.0 & 348 & 100.0 \\
\hline $\begin{array}{l}\text { Both parents } \\
\text { One parent... } \\
\text { Deitber parent } 1\end{array}$ & $\begin{array}{r}644 \\
64 \\
5\end{array}$ & $\begin{array}{r}91.3 \\
0.0 \\
.7\end{array}$ & $\begin{array}{r}339 \\
2-4 \\
2\end{array}$ & $\begin{array}{r}92.9 \\
6.6 \\
.5\end{array}$ & $\begin{array}{r}305 \\
40 \\
3\end{array}$ & $\begin{array}{l}8.6 \\
11.5 \\
.9\end{array}$ \\
\hline
\end{tabular}

1 ases of children living in foster homes.

\section{Number of persons in household.}

The number of persons in the household included not only the members of the child's immediate family but also any relatires, friends, roomers, and servants living under the same roof. ${ }^{19}$ Nearly threefifths (5\$.6 percent) of the children lived in houscholds including four. fire, or sir members. A few (4.7 pereent) lired in homes containing as many as 11 or more persons. (Table 5.)

\footnotetext{
1" The Southern New Encland Telephone Co. Market Survey of 1931 indicated that less than one-fifth of all the occupied dwellings in Jew Hsren were 1-family residences. See Appendix 11: (20) Dreis, pp. 9, 11.

Boarders were excluded.
} 
TABLs 5.-Number of persons in the houscholds in which the boys and girls lived

\begin{tabular}{|c|c|c|c|c|c|c|}
\hline \multirow{2}{*}{ Number of persons in household 2} & \multicolumn{2}{|c|}{ Both sexes } & \multicolumn{2}{|c|}{ Boyss } & \multicolumn{2}{|c|}{ Girls } \\
\hline & Number & I'ercent & Number & Percent & Number & Percent \\
\hline Total ................. & 37019 & 100.0 & 3364 & 100.0 & 3345 & 100.0 \\
\hline $\begin{array}{r}2 \\
3 \\
4 \\
5 \\
6\end{array}$ & $\begin{array}{r}3 \\
65 \\
140 \\
149 \\
127 \\
76 \\
58 \\
34 \\
23 \\
16 \\
11 \\
3 \\
3\end{array}$ & $\begin{array}{r}0.4 \\
9.2 \\
19.7 \\
21.0 \\
17.9 \\
10.9 \\
8.2 \\
4.8 \\
3.2 \\
2.3 \\
1.6 \\
.4 \\
.4\end{array}$ & $\begin{array}{r}0 \\
36 \\
76 \\
74 \\
55 \\
42 \\
29 \\
20 \\
13 \\
10 \\
5 \\
3 \\
1\end{array}$ & $\begin{array}{r}0.0 \\
9.9 \\
20.9 \\
20.3 \\
15.1 \\
11.5 \\
8.0 \\
5.5 \\
3.6 \\
2.7 \\
1.4 \\
.8 \\
.3\end{array}$ & $\begin{array}{r}3 \\
29 \\
6.1 \\
75 \\
72 \\
35 \\
25 \\
14 \\
10 \\
6 \\
6 \\
0 \\
2\end{array}$ & $\begin{array}{r}0.3 \\
5.4 \\
18.6 \\
21.7 \\
20.4 \\
10.1 \\
8.4 \\
4.1 \\
2.9 \\
1.7 \\
1.7 \\
.0 \\
.0\end{array}$ \\
\hline
\end{tabular}

1 Data based on observations made when the children were 6 years of age.

2 Number of persons in honsehold includect the child's immediate family, relatives, roormers, friends, and servants living under the same roof.

3 Number of persons in household was unkwown for I boy aud 3 girls.

\section{Number of persoms per room.}

If crowding is defined arbitrarily as one and one-half or more persons per room, ${ }^{20}$ it may be seen from table 6 that approximately 32 pereent of the children included in this study were living in homes where overerowding was a serious problem, although in about 43 percent of the houscholds there were from one to less than one and one-half persons per room, and about 25 percent of the children were living in homes with less than one person per room.

TA13LE 6.-Number of persons per room in the households in which the boys and girls lived 1

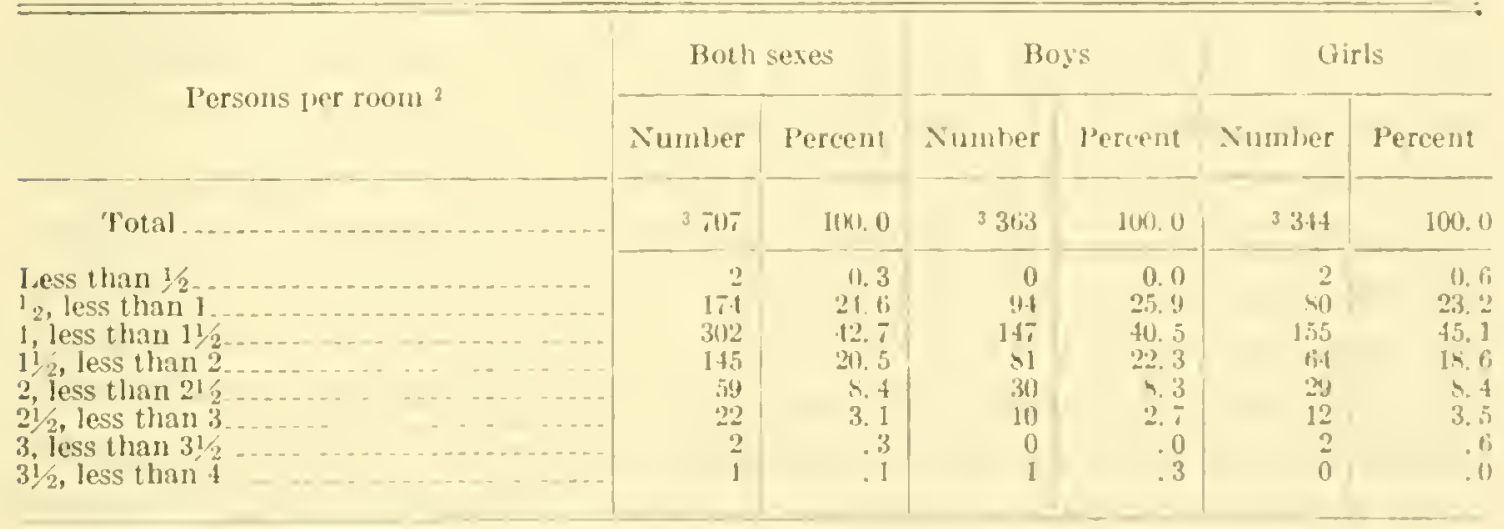

1 Data based on observations male when the children were ti years of age.

${ }^{2}$ The number of persons in the household included the child's immeilnte family, relatives, ronmers, friends, and servants living under the same roof. The number of rooms exeludel bathrooms and hallways.

y. Nimber of persons per room was unknown for 2 boys and il girls.

201 is recognized that any arhitrary stantard of crowding has limitathns. In this connoction Rollo $H$ 13ritton, of the National Institute of Ilraith, has pointed out that "a reasumble index shonhl repend mot only on persons per room but also on such faetors as uge and sex makenp of the tamily, size of roums, whet ber the dwelling unit is in a house or apartment, gographic location, "efe." sae Aplumlix II: (15) Britten.

It should be rememinere, howerer, that the nature of the present investigation has autematienlly restricted the type of family under consideration. livery chilil in this study comes from a housh hold! consisting of at least 2 p.rsons, a 6 -year-old child und an adult. A stamlard of erwwing apylied to a gronp of these familios is probably a mori reliable index of socioceonomic status than if it is applied to a less rigoronsly. defined group. 
Number of additional persons sleeping in the child's bedroom.

Another and perhaps a more sensitive index of crowding is the number of persons occupying one bedroom. About. 43 percent of the children included in this study slept in a room occupied by two or more additional persons, and approximately 44 percent slept in a room occupied by one other person. Only about 13 percent had their own bedrooms. (Table 7.)

TABLE 7.-Number of additional persons sleeping in the child's bedroom 1

\begin{tabular}{|c|c|c|c|c|c|c|}
\hline \multirow{2}{*}{$\begin{array}{l}\text { Additional persons occupying child's } \\
\text { room }\end{array}$} & \multicolumn{2}{|c|}{ Both sexes } & \multicolumn{2}{|c|}{ Boys } & \multicolumn{2}{|c|}{ Girls } \\
\hline & Number & Percent & Number & Percent & Number & Percent \\
\hline \multirow[t]{2}{*}{ Total } & 2707 & 100.0 & 2363 & 100.0 & ${ }^{2} 344$ & 100.0 \\
\hline & $\begin{array}{r}93 \\
307 \\
204 \\
74 \\
22 \\
6 \\
0 \\
1\end{array}$ & $\begin{array}{r}13.2 \\
43.4 \\
28.9 \\
10.5 \\
3.1 \\
.8 \\
.0 \\
.1\end{array}$ & $\begin{array}{r}53 \\
158 \\
107 \\
34 \\
10 \\
1 \\
0 \\
0\end{array}$ & $\begin{array}{r}14.6 \\
43.5 \\
29.5 \\
9.4 \\
2.7 \\
.3 \\
.0 \\
.0\end{array}$ & $\begin{array}{r}40 \\
149 \\
97 \\
40 \\
12 \\
5 \\
0 \\
1\end{array}$ & $\begin{array}{r}11.6 \\
43.3 \\
28.2 \\
11.6 \\
3.5 \\
1.5 \\
.0 \\
.3\end{array}$ \\
\hline
\end{tabular}

1. Data based on obserrations made when the children were 6 years of age.

2 Number of additional persons occupying same sleeping room as child was unknown for 2 boys and 4 girls.

\section{ECONOMIC STATUS OF THEIR FAMILIES}

\section{Assistance.}

With such conditions existing in the children's homes, it is reasonable to expect that a considerable number of families were in poor economic circumstances. If assistance from public or private agencies or both ${ }^{21}$ is used as a criterion, it may be seen from table 8 that this is so. Almost 24 percent of these boys' and girls' families received assistance during the year prior to the home visit made when the child was 6 years old and again when the child was 7 years of age, compared with 70 percent that received no assistance at any time during the period of observation. A few families (4.5 percent) received assistance during the first year only and a still smaller number (1.8 percent) during only the second year of the study. In other words, nearly one-fourth of the children's families received assistance from public or private agencies or both during the years prior to both home visits; most of the remaining families received no assistance either year.

\footnotetext{
${ }_{21}$ This information was obtained by the economic analysts at the houle visits, was eleared through the Social Service Exchange, and was ehecked with the records of the public and private ageneies giving direct and work relief in New 1 Iaven. In addition, families reporting an income of less than \$1.000 a year, those with a history of severe illness, and all other families whose income statements appeared inaccurate wero eleared through the Social Service Exchange.
} 
TABLE 8.-Assistance from public, private, or public and private agencies given the families of the boys and girls during the year preceding cach home visit

\begin{tabular}{|c|c|c|c|c|c|c|}
\hline \multirow{2}{*}{ Assistance I } & \multicolumn{2}{|c|}{ Both sexes } & \multicolumn{2}{|c|}{ Boys } & \multicolumn{2}{|c|}{ Girls } \\
\hline & Number & Pereent & Number & Percent & Number & Percent \\
\hline Total & 713 & 100.0 & 365 & 100.0 & 345 & 100.0 \\
\hline $\begin{array}{l}\text { First year only } \\
\text { Second year only. } \\
\text { Both years. } \\
\text { Neither year }\end{array}$ & $\begin{array}{r}32 \\
13 \\
169 \\
499\end{array}$ & $\begin{array}{r}4.5 \\
1.8 \\
23.7 \\
70.0\end{array}$ & $\begin{array}{r}16 \\
10 \\
92 \\
247\end{array}$ & $\begin{array}{r}4.4 \\
2.7 \\
25.2 \\
67.7\end{array}$ & $\begin{array}{r}16 \\
3 \\
7 \\
252\end{array}$ & $\begin{array}{r}4.6 \\
.9 \\
22.1 \\
72.4\end{array}$ \\
\hline
\end{tabular}

i Assistance given at any time during the 12 months preceding the home visit. This assistance took the form of direct relief, work relief, or direet and work relief from any public or private agency.

\section{Principal sonrce of income.}

What was the principal or major source of income of these boys' and girls' families during the year preceding the second home visit? Table 9 shows it to be the father's earnings in slightly more than twothirds (68.8 percent) of the homes; the mother's eamings, in about 4 pereent; assistance from public or private agencies or both, in 17 pereent; and other sources, in about 10 percent.

TABLE 9.- Principal source of income of the familics of the boys and girls during the year preceding the second home visit

\begin{tabular}{|c|c|c|c|c|c|c|}
\hline \multirow{2}{*}{ Prineipal source of income 1} & \multicolumn{2}{|c|}{ Borly seres } & \multicolumn{2}{|c|}{ Boys } & \multicolumn{2}{|c|}{ Girls } \\
\hline & Number & Percent & Number & lerecent & Number & Pיicent \\
\hline Total & ${ }^{2} 659$ & 100.0 & 2348 & 100.0 & 2311 & 100.0 \\
\hline $\begin{array}{l}\text { Work of father }{ }^{3} \\
\text { Work of mother }{ }^{3} \ldots \ldots \\
\text { Otlier sumeses } \\
\text { Assistanee }{ }^{3}\end{array}$ & $\begin{array}{r}174 \\
26 \\
72 \\
117\end{array}$ & $\begin{aligned} 618.5 \\
3.4 \\
10.1 \\
17.0\end{aligned}$ & $\begin{array}{r}236 \\
9 \\
36 \\
67\end{array}$ & $\begin{array}{r}07.4 \\
2.6 \\
10.3 \\
19.3\end{array}$ & $\begin{array}{r}234 \\
17 \\
36 \\
50\end{array}$ & $\begin{array}{r}69.9 \\
5.0 \\
10.5 \\
14.7\end{array}$ \\
\hline
\end{tabular}

: That source which entributed the major portion of the family income.

2 'The souree of ineorne was unknown for 17 hoys and 7 girls.

${ }^{3}$ bid not inclucle work relinf.

4 "Other sourees" included income from work of ehilifen, frnm relatives, savings, unemploynent and other types of compensatinn, insurance, and rent. It did not include incounc irom work relief.

3 "Assistance" ineludel both work relief and direct relief from jublic and private ageneies.

\section{Employment of mother. ${ }^{22}$}

In about 18 percent of the households the mother was ganfully employed, mostly outside the home. (Table 10.)

\footnotetext{
${ }^{22}$ In cases where thr child] was not living with his uwn mother, the information mertained to the woman in eharge of the houselsoli.
} 
TABLE 10. - Employment status of the mothers of the boys and girls during the year preceding the second home visit 1

\begin{tabular}{|c|c|c|c|c|c|c|}
\hline \multirow{2}{*}{ Employment stiatus } & \multicolumn{2}{|c|}{ Both sexes } & \multicolumn{2}{|c|}{ Boys } & \multicolumn{2}{|c|}{ Girls } \\
\hline & Number & Percent & Number & Pereent & Number & Pereent \\
\hline Total _. & 713 & 100.0 & 365 & 100.0 & 348 & 100.0 \\
\hline $\begin{array}{l}\text { Mother not employed } \\
\text { Mother employed }\end{array}$ & $\begin{array}{l}591 \\
129\end{array}$ & $\begin{array}{l}81.9 \\
18.1\end{array}$ & $\begin{array}{r}302 \\
63\end{array}$ & $\begin{array}{l}82.7 \\
17.3\end{array}$ & $\begin{array}{r}282 \\
66\end{array}$ & $\begin{array}{l}81.0 \\
19.0\end{array}$ \\
\hline $\begin{array}{l}\text { Inside home } \\
\text { Outside home } \\
\text { Unknown whether employed inside } \\
\text { or outside houle.. }\end{array}$ & $\begin{array}{r}12 \\
105 \\
12\end{array}$ & $\begin{array}{r}1.7 \\
14.7 \\
1.7\end{array}$ & $\begin{array}{r}6 \\
49 \\
8\end{array}$ & $\begin{array}{r}1.7 \\
13.4 \\
2.2\end{array}$ & $\begin{array}{r}6 \\
56 \\
4\end{array}$ & $\begin{array}{r}1.7 \\
16.1 \\
1.2\end{array}$ \\
\hline
\end{tabular}

1 In eases where the ehild was not living with his own mother, the information pertained to the woman in eharge of the household.

\section{Height.}

\section{ANTHROPOMETRIC MEASUREMENTS}

The heights of these children are given in table 11. As would be expected, there was considerable variation in the averages of the American and Italian boys and girls, the American child being taller on the average than the Italian. No comparison has been made between the children grouped under the heading "Other" and the American or Italian boys and girls, as the first-mentioned group of children represent so many nationalities that comparisons are not warranted.

'TABLE 11.-Meights of the boys and girls

\begin{tabular}{|c|c|c|c|c|c|c|c|c|}
\hline \multirow{2}{*}{ Height (in inehes) } & \multicolumn{4}{|c|}{ Boys } & \multicolumn{4}{|c|}{ Girls } \\
\hline & Total & Italian I & Ameriean 2 & Other ${ }^{3}$ & Total & Italian & American ? & Other ${ }^{3}$ \\
\hline Total & 365 & 166 & 65 & 134 & 348 & 164 & 65 & 119 \\
\hline $\begin{array}{l}41.0-41.9 \\
42.0-42.9 \\
43.0-43.9 \\
45.0-44.9 \\
46.0-45.9 \\
47.0-47.9 \\
48.0-48.9 \\
49.0-49.9 \\
50.0-50.9 \\
51.0-51.9 \\
52.0-52.9 \\
53.0-53.9 \\
54.0-54.9\end{array}$ & $\begin{array}{r}1 \\
8 \\
9 \\
34 \\
41 \\
57 \\
75 \\
51 \\
32 \\
29 \\
17 \\
6 \\
2 \\
0\end{array}$ & $\begin{array}{r}1 \\
6 \\
7 \\
25 \\
25 \\
29 \\
39 \\
20 \\
7 \\
5 \\
2 \\
0 \\
0 \\
0\end{array}$ & \begin{tabular}{r|r}
0 \\
1 \\
1 \\
2 \\
6 \\
12 \\
8 \\
13 \\
9 \\
6 \\
3 \\
4 \\
0 \\
0
\end{tabular} & $\begin{array}{r}0 \\
1 \\
1 \\
7 \\
10 \\
16 \\
28 \\
21 \\
16 \\
18 \\
12 \\
2 \\
2 \\
0\end{array}$ & $\begin{array}{r}0 \\
4 \\
9 \\
36 \\
55 \\
59 \\
71 \\
60 \\
25 \\
22 \\
4 \\
1 \\
1 \\
1\end{array}$ & $\begin{array}{r}0 \\
3 \\
7 \\
28 \\
36 \\
26 \\
27 \\
28 \\
5 \\
4 \\
0 \\
0 \\
0 \\
0\end{array}$ & $\begin{array}{r}0 \\
0 \\
0 \\
3 \\
5 \\
15 \\
11 \\
15 \\
9 \\
6 \\
0 \\
1 \\
0 \\
0\end{array}$ & $\begin{array}{r}0 \\
1 \\
2 \\
5 \\
14 \\
18 \\
33 \\
17 \\
11 \\
12 \\
4 \\
0 \\
1 \\
1\end{array}$ \\
\hline $\begin{array}{l}\text { Mean } \\
\text { Standari deviation. }\end{array}$ & $\begin{array}{l}47.5 \\
2.25\end{array}$ & $\begin{array}{l}.16 .5 \\
1.93\end{array}$ & $\begin{array}{c}48.1 \\
2.21\end{array}$ & $\begin{array}{l}48.3 \\
2.17\end{array}$ & $\begin{array}{l}47.1 \\
1.96\end{array}$ & $\begin{array}{l}16.4 \\
1.76\end{array}$ & $\begin{array}{l}47.8 \\
1.68\end{array}$ & $\begin{array}{l}47.8 \\
2.02\end{array}$ \\
\hline
\end{tabular}

' 3 of the ehild's grandparents were born in Italy.

230 ? the ehild's grandparents or 2 of his grandparents and both his parents were horn in the United States.

${ }^{3}$ These ehildren did not meet the definitions outlined in footnotes 1 and 2.

\section{Weighı.}

'The weights of the children are given in table 12. ${ }^{23}$ Here, as in hoight, there appera to be diflerences betweon the childern classified

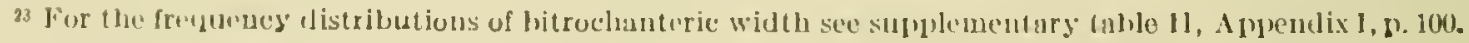


as Italian and as American, the Italian tending to weigh less than the American boys and girls.

TABLF, 12.-Weights of the boys and girls

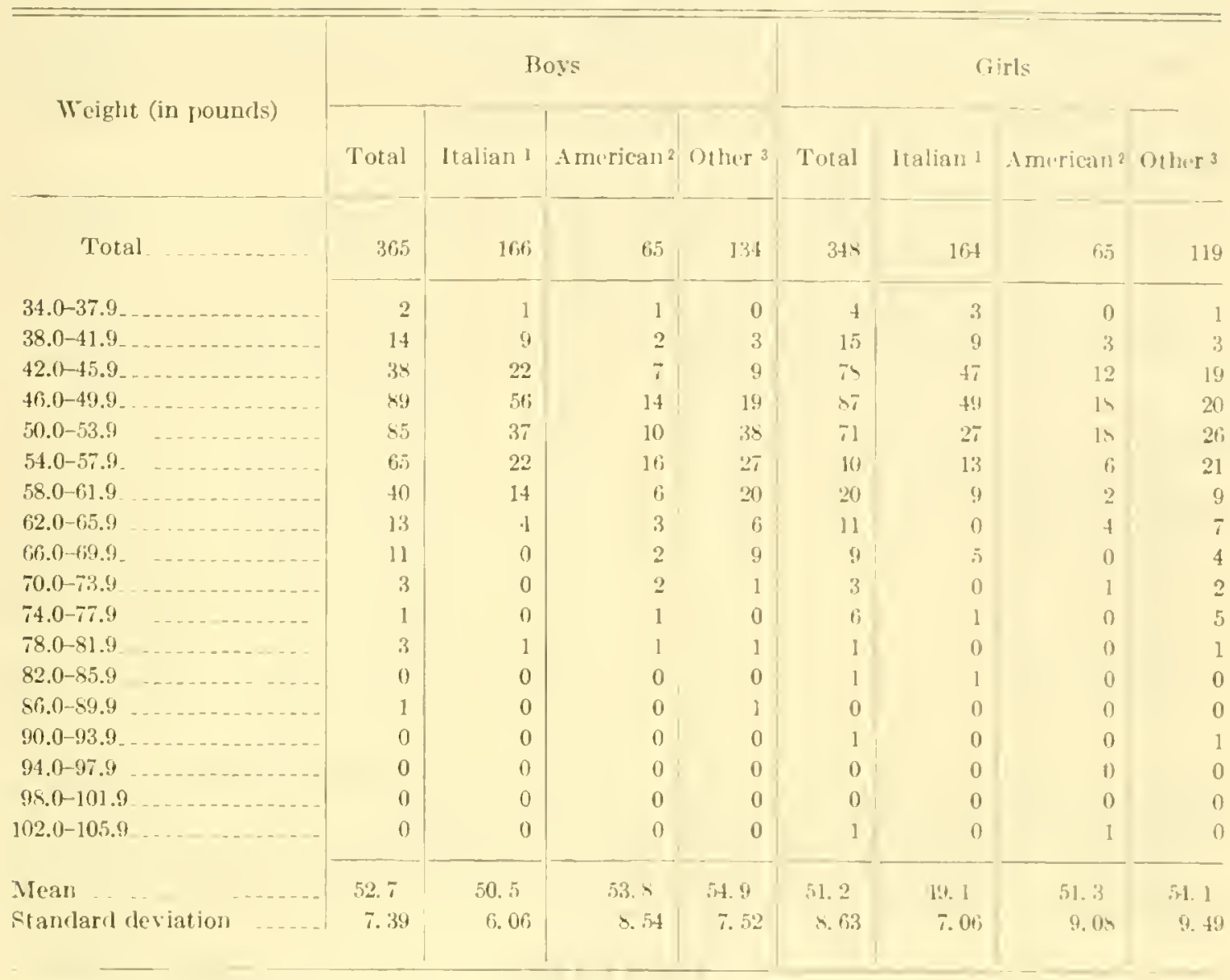

13 of the ehild's grantparents were born in ltaly.

23 of the ehild's grantparents or 2 of lis grandparents and both his parents were born in the Cuited States.

${ }^{3}$ T'hese children dicl not muet the definitions outlined in footmotes 1 and 2.

Such nationality diflerences are important becanse, as has been mentioned (see p. 2S), they may affect the efliciency of the indices in identifying boys and girls in need of medical attention or nutritional advice or assistance. The indices depend on estimates of body build (based on anthropometric measurements) for judging a child's phrsical fitness (insofar as pluysical fitness is related to abnormalitios in certain measures such as weight or arm girth) when the expected or arerage measure for children of the same sex, age, and build is used as a stamilard. Such a standard may vary with the nationality of the childeren from whose measurements it was derived and may. therefore, he most efficient in judging the fitness of childeren of the same nationality as the boys and girls whose mosurements were used in developing the index or'standard.

\section{I)IETS}

As information concerning the dietary habits of these drildwen is not very satisfactory, only the data on mills comsumption have been analyzed. ${ }^{24}$ (Table 13.) Although ist.5) pereent of the boys and girls

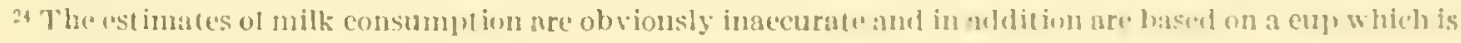
smaller than llo standard measure.
} 
drank an "adequate" amount (2,3, or 4 cups per day) of milk at 7 years of age, ${ }^{25}$ only 28.3 percent consumed an "optimum" amount ( 5 cups or more). On the other hand, a considerable proportion of these children (13.9 percent at the age of 7) had an inadequate amount (less than 2 cups per day) of milk in their diet, and a very small number of the boys and girls (1.3 percent at the age of 7 ) did not drink any milk.

TABLE 13.-Adequacy of the amount of milk consumed daily by the boys and girls

\begin{tabular}{|c|c|c|c|c|c|c|}
\hline \multirow{2}{*}{ Adequacy of milk consumed per day } & \multicolumn{2}{|c|}{ Both sexes } & \multicolumn{2}{|c|}{ Boys } & \multicolumn{2}{|c|}{ Girls } \\
\hline & Number & Percent 1 & Number & Percent & Number & Percent 1 \\
\hline \multicolumn{7}{|l|}{ No milk: } \\
\hline At 7 years & 9 & 1.3 & 3 & 0.8 & 6 & \\
\hline $\begin{array}{l}\text { At both } 6 \text { and } 7 \text { years } \\
\text { Inadequate:? }\end{array}$ & 0 & .0 & 0 & .0 & 0 & .0 \\
\hline \multicolumn{7}{|l|}{$\begin{array}{l}\text { Inadequate: } \\
\text { At } 7 \text { years }\end{array}$} \\
\hline At both 6 and 7 years & $\begin{array}{l}99 \\
99\end{array}$ & $\begin{array}{r}13.9 \\
5.4\end{array}$ & $\begin{array}{l}55 \\
25\end{array}$ & $\begin{array}{r}15.1 \\
6.9\end{array}$ & $\begin{array}{l}44 \\
14\end{array}$ & $\begin{array}{r}12.7 \\
4.1\end{array}$ \\
\hline \multicolumn{7}{|l|}{ Adequate: ${ }^{3}$} \\
\hline $\begin{array}{l}\text { At } 7 \text { years } \\
\text { At both } 6 \text { and } 7 \text { years }\end{array}$ & 402 & 56.5 & 200 & 55.0 & 202 & 58.2 \\
\hline \multicolumn{7}{|l|}{ Optimum: ${ }^{4}$} \\
\hline At 7 years & 201 & 28.3 & 106 & 29.1 & 95 & 27.4 \\
\hline At both 6 and 7 years. & 50 & 7.0 & 33 & 9.1 & 17 & 4.9 \\
\hline
\end{tabular}

1 The percentages in each ease were based on the total number of children for whom information at both 6 and 7 years of age was available: For both sexes, 711 ; for boys, 364; and for girls, 347 . (The amount of milk consumed daily was unknown for 1 boy and 1 girl at 7 years of age.)

"Inadequate" was defined as less than 2 cups per day.

3 "Adequate" was defined as 2 up to but not ineluding 5 cups per day. The absolute standard of 3 cups a day has not been adopted because the estimates of milk consumption are subject to error.

"Optimum" was defined as 5 or more cups per day.

\section{HEA LTH}

\section{Pediatrician's assessment of general nutritional status.}

As has been stated, all the children were examined both years of the study by one pediatrician, who judged their nutritional status to be "excellent," "good," "borderline," "poor," or "very poor." These estimates were based on careful physical examinations which were made according to detailed written instructions. ${ }^{26}$

On the basis of these examinations the percentage of children in each mutritional class was as follows:

(1) More than half the boys and girls were judged to be in a borderline condition at 7 years of age. Some of them were probably fairly well nourished; others were in a nutritional eondition that bordered on poor. Nevertheless, all these children eonstitute a health problem,

\footnotetext{
25 The standard of 3 cups per day as adcquate and 4 cups as optimum has not been applied. (See Appendix II: (10.9) Sherman and Hawley.) Instead, 2 up to but not inclurling 5 cupsa day (an average of 312 cups) has been considered adequate; Jess than 2 cups, inadequate; and 5 eups or more, an optimum amount. This grouping has been made in order primarily to identify 2 of the 3 groups of children: (1) Those who had a definitely unsaisfactory amount of milk in their dicts as compared with (2) those who had an optimum amount.

$28 \mathrm{~A}$ detailed evaluation of both the objectivity and the stability of the pediatrician's judgment oceurs on pl. 82-87.
} 
as they are difficult to identify and their condition may grow progressively worse if they do not receive proper care and treatment.

(2) About 34 percent of the boys and girls were judged to be in good or excellent nutritional condition (30.2 pereent good and 3.4 percent excellent) at 7 years of age.

(3) Necessarily, if about 57 pereent of the children were rated as in borderline and about 34 percent in good or excellent nutritional condition, only a small pereentage (9.5 percent) could have been judged by the physician to be poorly or very poorly now ished at 7 years. All these children, 28 out of 365 boys and 40 out of 345 girls, were classified as poorly nourished; none of them as very poorly nourished.

It is also interesting to note (table 14) that, according to this pediatrician's judgment, about 5 pereent of the children were poorly nourished during both years of the study, compared with about 9 percent at 7 years of age.

TABLE 14.-Pediatrician's assessment of nutritional status of the boys and girls

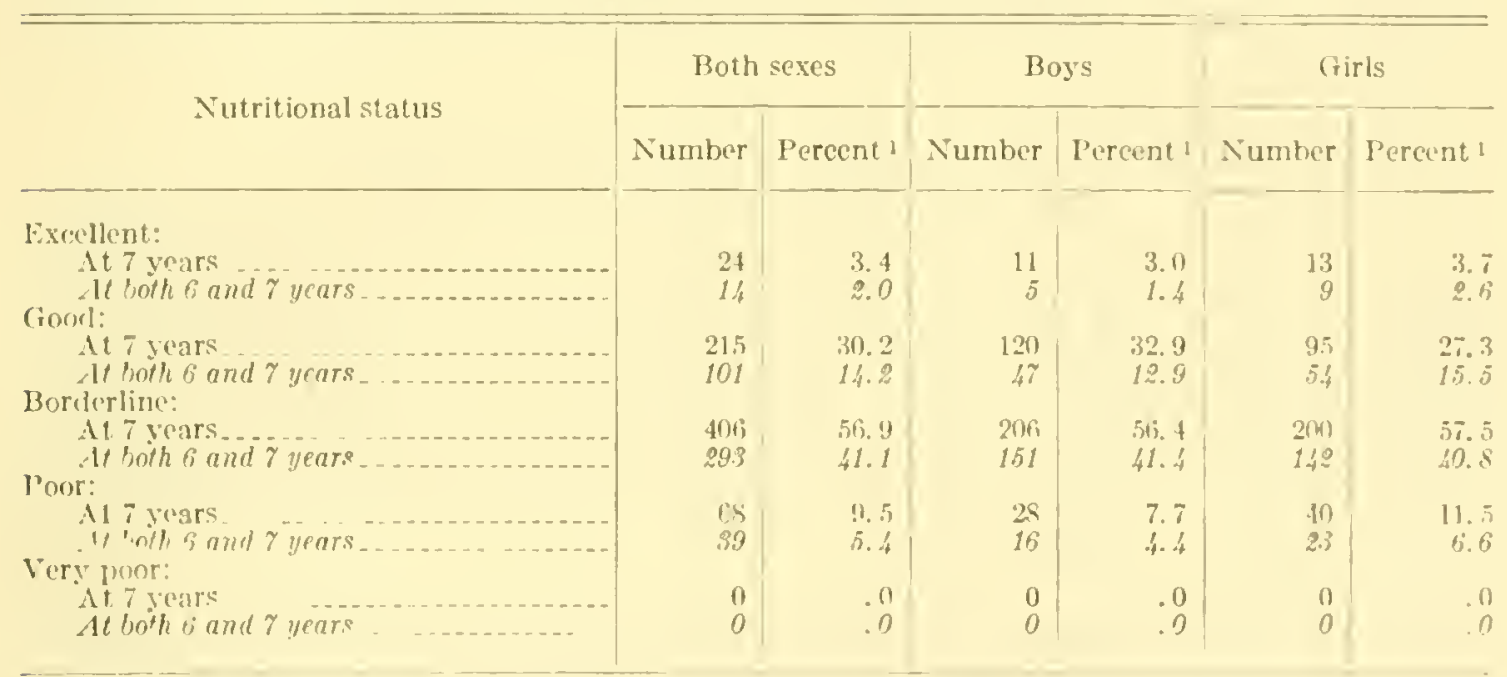

1 The percentages in eacel cas wern hasel on the total mumber we children for whom information at both fi and 7 years of age was availat ?: For both soxes, 713: fol boys, 365; and for sirls, 3.19,

\section{Dirgmoses mude at anmunl physical exuminalions. 27}

The diagnoses made at the eximinations givon when the children were 6 and again when they were 7 years of age are shown in table 15. At 7 years of age 53 pereent of the hoys and girls were found to be suffering from various ailments, mostly of the respiratory tract. Lnder nonrespiratory infections only one case of rhemmatic heart disease was included, and under the heading "Other" positive diagnoses," three concenital heart conditions. With few exceptions, the rest of the diagnosis were of minor importance. This is not surprising, for all the ehildren were well rnough to attend school and to be under observation for approximately a 2-yor period.

2) If more than 1 dingnosis was made at a given examination, that which the periatrician considret most important clinically was recorded. 
TABLE 15.-Diagnoses made at the anmual physical examinations of the boys and girls

\begin{tabular}{|c|c|c|c|c|c|c|c|c|c|c|c|c|}
\hline \multirow{3}{*}{ Diagnosis } & \multicolumn{4}{|c|}{ Both sexes } & \multicolumn{4}{|c|}{ Boys } & \multicolumn{4}{|c|}{ Girls } \\
\hline & \multicolumn{2}{|c|}{ At 6 years } & \multicolumn{2}{|c|}{ At 7 years } & \multicolumn{2}{|c|}{ It 6 years } & \multicolumn{2}{|c|}{ At 7 years } & \multicolumn{2}{|c|}{ At 6 years } & \multicolumn{2}{|c|}{ At 7 years } \\
\hline & $\begin{array}{l}\text { Num- } \\
\text { ber }\end{array}$ & $\begin{array}{l}\text { Per- } \\
\text { ecnt }\end{array}$ & Num- & $\begin{array}{l}\text { Per- } \\
\text { eent }\end{array}$ & Num- & $\begin{array}{l}\text { Per- } \\
\text { cent }\end{array}$ & Num- & $\begin{array}{l}\text { Per- } \\
\text { cent }\end{array}$ & Num- & $\begin{array}{l}\text { Per- } \\
\text { cent }\end{array}$ & Num- & $\begin{array}{l}\text { Per- } \\
\text { cent }\end{array}$ \\
\hline Total & 713 & 100.0 & 713 & 100.0 & 365 & 100.0 & 365 & 100.0 & 348 & 100.0 & 348 & 100.0 \\
\hline $\begin{array}{l}\text { No disease } \\
\text { Disease } 1\end{array}$ & $\begin{array}{l}265 \\
448\end{array}$ & $\begin{array}{l}37.2 \\
62.8\end{array}$ & $\begin{array}{l}335 \\
378\end{array}$ & $\begin{array}{l}47.0 \\
53.0\end{array}$ & $\begin{array}{l}119 \\
246\end{array}$ & $\begin{array}{l}32.6 \\
67.4\end{array}$ & $\begin{array}{l}152 \\
213\end{array}$ & $\begin{array}{l}41.6 \\
58.4\end{array}$ & $\begin{array}{l}146 \\
202\end{array}$ & $\begin{array}{l}42.0 \\
58.0\end{array}$ & $\begin{array}{l}183 \\
16.5\end{array}$ & $\begin{array}{l}52.6 \\
47.4\end{array}$ \\
\hline Infectious disease & 444 & 62.3 & 374 & 52.5 & 243 & 66.6 & 211 & 57.8 & 201 & 57.7 & 163 & 46.8 \\
\hline $\begin{array}{l}\text { Respiratory } \\
\text { Nonrespiratory } \\
\text { Other }{ }^{2}\end{array}$ & $\begin{array}{r}273 \\
171 \\
4\end{array}$ & $\begin{array}{r}38.3 \\
24.0 \\
.5\end{array}$ & $\begin{array}{r}232 \\
142 \\
4\end{array}$ & $\begin{array}{r}32.6 \\
19.9 \\
.5\end{array}$ & $\begin{array}{r}163 \\
80 \\
3\end{array}$ & $\begin{array}{r}44.7 \\
21.9 \\
.8\end{array}$ & $\begin{array}{r}136 \\
75 \\
2\end{array}$ & $\begin{array}{r}37.3 \\
20.5 \\
.6\end{array}$ & $\begin{array}{r}110 \\
91 \\
1\end{array}$ & $\begin{array}{r}31.6 \\
26.1 \\
.3\end{array}$ & $\begin{array}{r}96 \\
67 \\
2\end{array}$ & $\begin{array}{r}27.6 \\
19.2 \\
.6\end{array}$ \\
\hline
\end{tabular}

1 If more than 1 diagnosis was made at a given cxamination, that which the pediatrician considered the most important clinically was recorded.

2 "Other" included asthma and congenital heart conditions.

Two other items may be useful in indicating the general physical condition of the boys and girls included in this study: (1) School absences; and (2) the physician's judgment of the child's need for medical or dental care.

\section{Number and duration of reportable school absences.}

Only absences of 3 or more school days' duration are reportable in New Haven. The school nurse's files show the number of such absences, the total number of school days which they represent, and the reasons for the absences. Only absences due to illness have been recorded, and the material has been analyzed in terms of the association between the duration of reportable absenes cand the number of such absences. (Table 16.)

TABLE 16.-Association between the number of reportable absences during the school year and the duration of these absences ${ }^{1}$

\begin{tabular}{|c|c|c|c|c|c|c|c|c|}
\hline \multirow[b]{2}{*}{ Number of reportable absenees? } & \multicolumn{7}{|c|}{ Duration of reportable absences } & \multirow[b]{2}{*}{ Total } \\
\hline & 0 & $3-4$ & $5-9$ & $10-14$ & $15-19$ & $20-29$ & $\begin{array}{l}30 \text { or } \\
\text { more }\end{array}$ & \\
\hline $\begin{array}{l}0 \\
1 \\
2 \\
4\end{array}$ & $\begin{array}{r}186 \\
0 \\
0 \\
0 \\
0\end{array}$ & $\begin{array}{r}0 \\
102 \\
0 \\
0 \\
0\end{array}$ & $\begin{array}{r}0 \\
107 \\
49 \\
1 \\
0\end{array}$ & $\begin{array}{r}0 \\
20 \\
54 \\
22 \\
3\end{array}$ & $\begin{array}{r}0 \\
5 \\
17 \\
20 \\
4\end{array}$ & $\begin{array}{r}0 \\
7 \\
22 \\
19 \\
12\end{array}$ & $\begin{array}{r}0 \\
8 \\
8 \\
i \\
18\end{array}$ & $\begin{array}{r}180 \\
249 \\
150 \\
69 \\
39\end{array}$ \\
\hline 'Total.. & 186 & 102 & 157 & 99 & 46 & 60 & 42 & ${ }^{3} 692$ \\
\hline
\end{tabular}

I The data on school ahsenees have not been presented semarately for boys and girls, beeause analysis failerl to reveal any sex difference in either the number or the duration of reportablo absences.

2 I reportable absence is an absence of 3 or inoro school lay's.

3 Information on school absenees was lacking for 8 boys and 13 girls.

During $1935-36$, when the children were 7 years of age, approximately 27 percent of the boys and girls had no reportable school 
absences. ${ }^{28}$ It should be remembered, however, that these children may have been absent any number of days during the year if each absence were of less than 3 school days' duration. It is unfortunate that such boys and girls have not been differentiated from the children who had no absences, for a sickly child who is able to attend school except for absences of a day or two should be distinguished from a healthy boy or girl who never misses school. On the other hand, none of these children had any protracted illnesses during the school year, although it may well be that some of the boys and girls frequently suffered from minor ailments which undermined their health but did not materially affect their attendance at school.

Most of the other boys and girls (36.0 percent of all the children) had only one reportable absenee. This absence usually lasted from 3 to 9 school days (41.0 percent, 3 or 4 days, and 43.0 pereent, 5 to ? days); there were a few boys and girls (10.0 percent) absent from 10 to 19 days, and an even smaller number (6.0 pereent) absent 20 days or more.

About 22 pereent of all the children were absent twice for periods of 3 school days or more. About one-third of these boys and girls were out less than 10 days; a somewhat larger proportion (36.0 percent), 10 to 14 days; and the others (31.3 pereent). 15 days or longer.

Finally, a considerable number of the children (more than 1.5 percent of the total) were reported as having had three or more abscnees at 7 years. These boys and girls were usually absent for long periods. Twenty-nine percent of them were not at school for 20 to 29 days, and nearly one-fourth of these children had reportable absences totaling 30 school clays or more. ${ }^{29}$

\section{Medical and dental care.}

When the pediatrician examined the children each year she indieated whether they needed medical eare or dental ware or hoth (table 17). Analysis of her findings shows that nealy 60 perent of the boys and girls were in need of both medical and dental care at 7 years of age, and that slightly more than 40 pereent needed such care at hoth 6 and 7 years. In other words, nearly hilf the children were in need of medical and dental care during both years of the study. Even more significant, perhaps, is the fact that only abont 2 pereent of the boys and girls needed neither molical nor dental care at 7 grals of age and that only 1 pereent of the childeren merded neither yege of care at 6 or at 7 years of age.

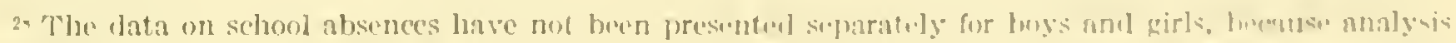
failed to reveal any sex differenoes in rither the number or the duration of reportaline alsenenes.

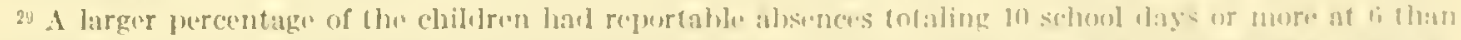

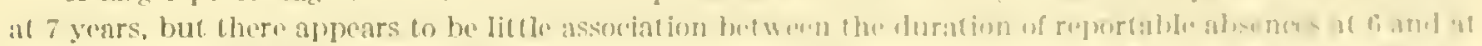

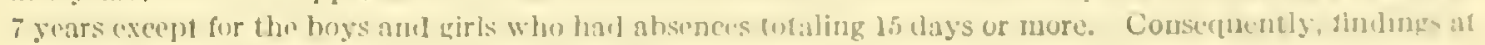
the earlier age have been onilted from the discussion.
} 
In interpreting these findings it should be remembered, however, that need for medical care refers to observation as well as treatment; undoubtedly many of the children needed observation only, because of a reported history of colds, perhaps; or such conditions as dull ear drums; mouth breathing; or moderately enlarged tonsils.

TABLE 17. - Recommendation of the pediatrician on the need of the boys and girls for medical and dental care

\begin{tabular}{|c|c|c|c|c|c|c|}
\hline \multirow{2}{*}{ Type of care needed } & \multicolumn{2}{|c|}{ Both sexes } & \multicolumn{2}{|c|}{ Boys } & \multicolumn{2}{|c|}{ Girls } \\
\hline & Number & Percent 1 & Number & Percent 1 & Number & Percent 1 \\
\hline \multicolumn{7}{|l|}{ Medical and dental care: } \\
\hline At 7 years & 422 & 59.2 & 215 & 58.9 & 207 & 59.5 \\
\hline At both 6 and 7 years & 296 & 41.5 & 150 & 41.1 & 146 & 42.0 \\
\hline At 7 years & 7 & 1.0 & 3 & .8 & 4 & 1.1 \\
\hline At both 6 and 7 years & 3 & .4 & 2 & .5 & 1 & 1.8 \\
\hline \\
\hline At both 6 and 7 years & $\begin{array}{l}271 \\
123\end{array}$ & $\begin{array}{l}38.0 \\
17.2\end{array}$ & $\begin{array}{r}143 \\
66\end{array}$ & 39.2 & $\begin{array}{r}128 \\
0 \gamma\end{array}$ & $\begin{array}{l}36.8 \\
16.4\end{array}$ \\
\hline \multicolumn{7}{|l|}{ No care: } \\
\hline At 7 years & 13 & 1.8 & 4 & 1.1 & 9 & 2. 6 \\
\hline At both 6 and $\gamma$ years & 8 & 1.1 & 1 & .3 & $\gamma$ & 2.0 \\
\hline
\end{tabular}

1 The percentages in each case were based on the total number of children for whom information at both 6 and 7 years of age was available: For both sexes, 713; for boys, 365; and for girls, 348.

\section{SUMMARY}

Most of the boys and girls were between 7 and $7 \frac{1}{2}$ years of age when the indices were tested. Nearly half of them were Italian, and nearly 20 percent were American children; the others represented various smaller nationality groups.

The different sections of New Haven were all fairly well represented. Most of the children lived in flats or apartments with both their parents; and there were generally four, five, or six persons living in their homes. Considerable overcrowding existed; about 32 percent of the boys and girls lived in households where there were one and one-half or more persons per room and in about 43 percent of the homes at least two people were occupying the same bedroom with the child who was included in this study. Some of these boys and girls were in extremely poor ecoromic circumstances; about 24 percent of their families received assistance (from public, private, or both public and private sources) during the year prior to each of the home visits. Even more significant is the fact that 17 percent of the families were dependent on such assistance for the principal part of their income during the second year of the study.

There were marked differences in the body build of these boys and girls. For example, the Italian children were shorter and tended to weigh less, on the average, than the American children.

The diets, judged in terms of the number of cups of milk consumed per day, were often inadequate. At 7 years of age, only about $2 S$ per- 
cent of the boys and girls drank an optimum amount (five or more cups); about 15 pereent of the children had less than two eups per day.

If the physician's judgment is used as a criterion of general nutitional status, about 34 percent of the boys and girls were in good or excellent nutritional condition at the time the indices were applied (at 7 years); almost 57 percent were in a borderline condition, and approximately 9 percent were judged to be poorly nourished.

Other evidence which gives some indication of the health of these children includes: (1) The specific clinical findings at the physical examinations; (2) absence from school; and (3) the physician's judgment of the boys' and girls' need for medical and dental care.

(1) At the time the second physical examinations were made, the physician found more than half the boys and girls suffering from various ailments, mostly respiratory-tract infections.

(2) Of the boys and girls with reportable school absences (i. e., absences of 3 school days or more) at 7 years of age, 36.0 percent were absent only once, 21.7 percent, twice, and 15.4 percent, three or more times. A large proportion (53.3 pereent) of those who had been out three or more times were out of school for as much as 20 school days or longer.

(3) According to the physician's judgment, nearly 60 percent of the children were in need of both medical and dental care at 7 years, and slightly more than 40 percent at both 6 and 7 years of age. A child in need of medical attention was almost always in need of dental care, although the reverse was not generally true.

All these findings-medical, dental, and socioconomic-indicate that without doubt there must be boys and girls included in this study who were likely to be undermourished and to be in need of medical care or nutritional advice and assistance.

\section{The Observations Made of 'These Children}

\section{TECHNIQUES EMPLOYED}

Every attempt was made to have the observations of these boys and girls as accurate as possible. In order to accomplish this purpose, uniform methods of collecting the material and editing the schedules were used.

No attempt will be made to describe each of the observations. ${ }^{30}$ On the other hand, the most important items-namely, clinical judgment of the child's nutrition and anthropometric measurements-will be described in some detail.

3u Iustructions for making the plyysical examinations, for toking the anthropometrie mosurements, and for obtaining socioconomic data, ingther with the scherbles for recording fluse observations may he obtained upon recuest from the Children's Bureau, U. S. J)enament of labbor. 


\section{Clinical assessment.}

For many years clinical judgment has been the accepted method of assessing a child's physical fitness. With increasing knowledge, improvements have been made in the procedures used in the examination and in the method of arriving at a final judgment of the child's general nutritional status. But the physical examination which forms a part of the usual school health program does not always include these techniques, because they may require specially trained personnel or new equipment or both, and because some of them consume considerable time in the examining room or in the laboratory. In other words, such tests are costly, and most school budgets have not expanded sufficiently to support so expensive a program. These more elaborate procedures ${ }^{31}$ were excluded, therefore, from the present study in order to have the physical examinations comparable to the examinations included in the ordinary school health program.

There were two other reasons which made it advisable to exclude these specialized tests. First, they present many administrative and technical problems. Thus specific permission must be obtained from parents or guardians of the children before some of the procedures may be applied. Second, some of the tests have not been standardized sufficiently to permit accurate interpretation.

But even if these considerations could have been eliminated, the first reason still remained; namely, the advantage of having the physical examinations of the boys and girls in this study comparable to examinations which it is administratively practical to employ in a school health program today. If the physical examinations are made in this way, the four indices included in the study can then be compared with the type of examination which they would ordinarily be used to supplement or replace. Furthermore, a study of the objectivity of clinical judgment of general nutritional status based on this type of examination might furnish some clues as to how to improve the physical examination without the addition of elaborate and expensive tests. In short, it was considered more important to use carefully a method which the average school physician can and must employ than to set up an claborate and costly procedure which it is not at present practical to adopt in examining large groups of school children.

In order to make the examination as objective and accurate as possible, detailed written instructions were prepared for the pediatrician's use concerning the number of items to be included in the examination and the method of evaluating each item. In addition, a 5point scale was devised for judging the child's general nutritional status (see chart entitled "Grading of General Nutritional Status" p. 43).

31 Exergut for hemoglobin and red-blood-enll detcrminations male on the first day of the check-up examinations on 133 chillen (70 boys and (33 girls) who were induded in the study. 


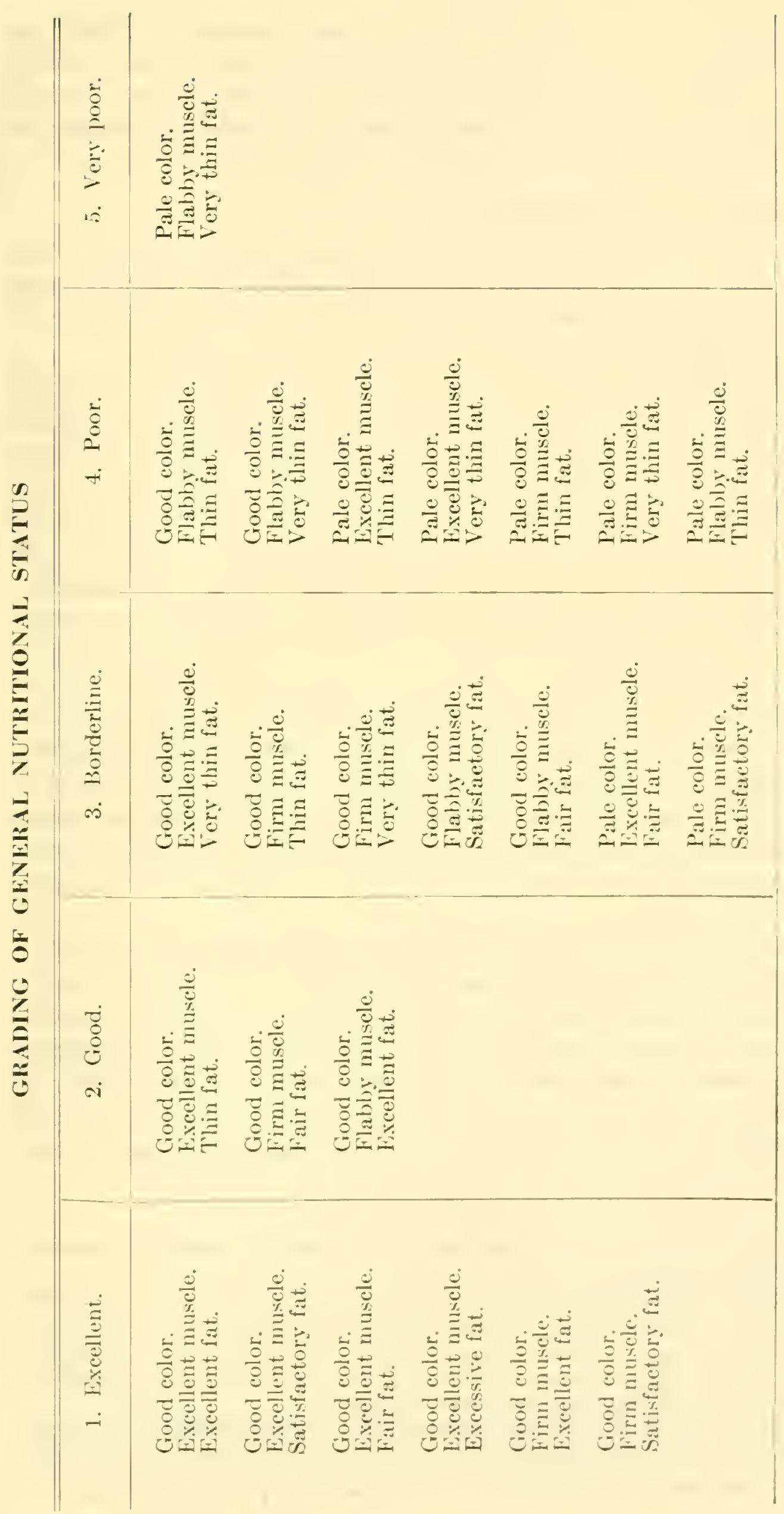


This seale was based on (1) color of mucous membranes, ${ }^{32}(2)$ quality of muscle, ${ }^{33}$ and (3) amount of fat, ${ }^{34}$ and was used as a guide in evaluating nutrition. Other items, including posture, condition of the skin and hair, and general development, were given consideration in arriving at a final elinical judgment of the child's general nutritional status. ${ }^{35}$

\section{Anthropometric measurements.}

The anthropometric measurements necessary for determining the Baldwin-Wood, Nutritional Status, $\mathrm{ACH}$, and Pryor Indices were made according to the methods recommended by the investigators ${ }^{36}$ with the following exeeptions:

Weight.-After his shoes, sweater, and coat were removed, the child was weighed on a balance scale located in the school and his weight was recorded to the nearest quarter of a pound. This is the procedure used for the Baldwin-Wood, the ACH, and the Nutritional Status Indices. In calculating the Pryor Index, there is a correction to allow for clothing if weight is not taken in the nude. This adjustment has been made for each boy and girl included in the present study.

Iliac crests. - When the children were 7 years old the crest measurements were taken next to the skin, according to the prescribed techniques, with a sliding wooden caliper. However, during the first 3 months of the study (October through December 1934), the bi-iliac diameter was taken over the elothing with an obstetric metal caliper. This difference in technique will not affect the indices, because the incorrect technique was used only in the first 3 of the 5 months during which the examinations of the 6-year-old children were made, whereas the indices were derived from measurements made when these children were 7 years of age.

The instruments used in taking the measurements were checked frequently; that is, the steel tape equipped with a Gulick spring handle, used in making the Franzen and ACH measurements, and the subeutaneous-tissue calipers for the Franzen Indices, were compared at weekly intervals with standardized instruments. About every 2 months they were returned to the factory for replacement of springs or for calibration. In addition, the seales located in each of the schools were balaneed at frequent intervals.

32 Color of inucous mombranes was assessed as "good" or "definitely pale."

${ }_{33}$ Clinieal judgment of musele which was graded as "excellent," "firm," or "flabby," was based on a comhination of muscle pull and muscle tone.

${ }^{34}$ Clinical jurgment of fat which was graded as "excessive," "excellent," "satisfactory," "fair," "thin," or "very thin," was basel on an average of the amount of arm and abdumen fat.

as Diagnoses hased on physieal "xaminations were not used in arriving at a judgment of the child's general nutritiona stat us exeyt insofar as they affected the elinical items entering into the assessment. Nevertheless, such diagnose's nay have infueneed the pediatrician unconsciously, although prery effort was male to hase the assessment wholly on the items specifed in the instruetions.

36 For a detailed description of the methods of taking the anthropometric measurements necessary for computing each index, see the following referenees given in Aprendix 11: 13aldwin-Wood Tables-(5) 13aldwin, j). 1; A Cli Index-(85) Franzen and Palmer, pp. 9-11; Nutritional Status Indices-(75) Nutritional Status Indices, pp. 7-12; and Pryor Width-Weight Tables-(88) Pryor and Stolz, p. 3, and (86) Pryor, p. 8. 


\section{ACCURACY OF THE TECHNIQUES EMPLOYED}

\section{Clinical assessment.}

It will be remembered that all the physical examinations were made during both years of the study by one pediatrician, who used detailed written instructions as an aid in arriving at her assessment of the children. Sinec her judgment of general nutritional status has been used both as a method of assessment and as a critcrion for craluating the four indices of body build, it is important to determine both its objectivity and its stability. In order to study these two problems, check-up examinations were made of some of the children after the physical examinations were completed in March 19:36. They consisted of two parts: (1) An initial and repeat eximination of some of the children ( 51 boys and 52 girls) by the same pediatrician who made all the physical examinations during both ycars of the study, in order to check the stability of her judgment; and (2) examinations of these same children and of 105 others (56 boys and 49 girls) by the same physician and by two additional pediatricians, in order to determine the extent of agreement in judgment among the three physicians. The findings are presented in a later section of this report. (Sce pp. 82-87.)

\section{Anthropometric measurements.}

At the same time that the check-up cxaminations were made, the accuracy of the anthropometric measures was studied in this manner: ${ }^{37}$ One hundred children (50 boys and 50 girls) were measured twice by anthropometrist $D$, who made all the measurements during both years of the study, and between D's initial and repeat observations were measured by another anthropometrist, E.

In order to study the variability of the anthropometric data, the initial measurements of ach anthropometric characteristic made by anthropometrist D have been compared with the measurements of the other observer, E. This comparison has been made in terms of the moans and standard deviations of the two distributions; that is, if D and E measured the children with an equal degree of acenrater, the means as well as the standard deviations of the distributions should coincide. Conversely, if the two observers' measuremonts were not made with the same precision, the means or the standard deviations or both will not be identical. Usually, howerer, the means coincide. and under these circumstances the anthenometrist whose meansurements have the smaller standarel deviation is the more alecurate of the two.

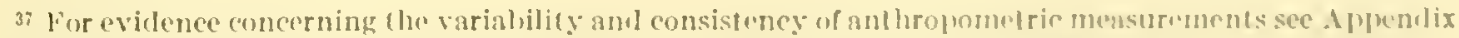
I]: (12) Hojel, (45) Hejinian and Hate, (56) Lincoln, (66) Marshall, an! (6i) Mrredill.
} 
To illustrate this method the reader is reminded that D and $\mathrm{E}$ each measured the bitrochanteric width of 50 7-year-old boys. Analysis shows that the average or mean bitrochanteric width for D's observations is $21.9 \mathrm{~cm}$. (table 18); and their dispersion, measured in ter'ms of the standard deviation, is $1.36 \mathrm{~cm}$. If this value is added to and subtracted from the mean, the limits obtained, 20.5 and 23.3 $\mathrm{cm}$., define an interval that includes slightly more than two-thirds of D's measurements.

TABLE 18. - Means and standard deviations of anthropometric measurements made by observers $D$ and $E$ on 50 boys and 50 girls

\begin{tabular}{|c|c|c|c|c|c|c|c|c|}
\hline \multirow{4}{*}{ Anthropometric measurement } & \multicolumn{4}{|c|}{ Boys } & \multicolumn{4}{|c|}{ Girls } \\
\hline & \multicolumn{2}{|c|}{ Mean } & \multicolumn{2}{|c|}{$\begin{array}{l}\text { Standard } \\
\text { deviation }\end{array}$} & \multicolumn{2}{|c|}{ Mean } & \multicolumn{2}{|c|}{$\begin{array}{l}\text { Standard } \\
\text { deviation }\end{array}$} \\
\hline & \multicolumn{2}{|c|}{ Observer- } & \multicolumn{2}{|c|}{ Ohserver- } & \multicolumn{2}{|c|}{ Observer- } & \multicolumn{2}{|c|}{ Observer- } \\
\hline & $\mathrm{D}$ & $\mathrm{E}$ & $\mathrm{D}$ & $\mathrm{E}$ & $D$ & $\mathrm{E}$ & $\mathrm{D}$ & $\mathbf{E}$ \\
\hline $\begin{array}{l}\text { Arm girth (cm.) } \\
\text { Bi-iliac crests (width) (cm.) } \\
\text { Bitrochanteric width (cm.) } \\
\text { Chest breadth I (cm.) } \\
\text { Chest depth }{ }^{1} \text { (cm.) } \\
\text { Height (in.) } \\
\text { Subcutancous tissuc } \\
\text { Weight (1b.) }\end{array}$ & $\begin{array}{l}35.4 \\
20.0 \\
21.9 \\
38.9 \\
28.3 \\
47.3 \\
23.5 \\
52.9\end{array}$ & $\begin{array}{l}35.1 \\
19.6 \\
21.8 \\
39.3 \\
28.8 \\
47.3 \\
24.3 \\
53.0\end{array}$ & $\begin{array}{l}\text { 3. } 45 \\
1.20 \\
1.36 \\
1.86 \\
\text { 1. } 63 \\
2.19 \\
\text { 3. } 39 \\
8.73\end{array}$ & $\begin{array}{l}\text { 3. } 37 \\
1.22 \\
1.42 \\
2.03 \\
1.94 \\
2.18 \\
3.32 \\
8.68\end{array}$ & $\begin{array}{l}35.4 \\
19.9 \\
22.1 \\
38.4 \\
27.8 \\
47.6 \\
26.0 \\
52.9\end{array}$ & $\begin{array}{l}35.1 \\
19.8 \\
22.1 \\
35.9 \\
28.5 \\
47.7 \\
27.7 \\
53.0\end{array}$ & $\begin{array}{l}3.61 \\
1.02 \\
1.20 \\
2.21 \\
1.91 \\
2.00 \\
4.41 \\
8.12\end{array}$ & $\begin{array}{l}\text { 3. } 42 \\
1.12 \\
1.22 \\
2.28 \\
1.91 \\
1.98 \\
4.84 \\
8.04\end{array}$ \\
\hline
\end{tabular}

This anthropometric characteristic is the sum of 2 measurements. See Appendix II: (7j) Nutritional Status Indices, pp. $7-12$, for a description of this measure.

A similar analysis made of E's observations shows that the mean is $21.8 \mathrm{~cm}$., and the standard deviation, $1.42 \mathrm{~cm}$., compared with 21.9 and $1.36 \mathrm{~cm}$. for D's measurements. (Table 18.) Now, if this standard deviation, $1.42 \mathrm{~cm}$, is added to and subtracted from the mean, $21.8 \mathrm{~cm}$., the limits obtained, 20.4 and $23.2 \mathrm{~cm}$., are about the same as those for D's observations (20.5 and 23.3). These findings indicate that there is excellent agreement between the two anthropometrists' measurements of the bitrochanteric width of 7 -year-old boys. The data for the 50 girls included in these anthropometric examinations also show close agreement between the two observers. (Table 18.)

Similar analyses of the other anthropometric characteristics of these boys and girls are shown in table 18. It may be seen upon examination of this table that the largest crrors for the boys were made in measuring chest depth, chest breadth, and arm girth, in the order named, and for girls, in subcutaneous tissue, arm girth, and width of the iliac crests. As a whole, however, the observations of D and E were in very close agreement. ${ }^{38}$

39 for any given anthropometric characteristie the error of the measurement has locen assumed to be dircetly proportional to the difference betwen the mumber of sesle units within the interval defined hy the mean, plus and minus 1 stumdard leviation, for the measurements made by each of the observers, D and F. 
The stability of D's measurements has been studied in terms of the error involved in making repeat measurements of each anthropometric characteristic (except weight and height) on the 50 boys and the 50 girls included in the anthropometric check-up observations.

If it is assumed that each of these two measurements, the first and repeat observations, contains chance, uncorrelated error's, the stability of D's measurements may be tested in terms of a statistical constant, which estimates their dispersion or variability. This constant, known as the standard deviation of a difference $\left(\sigma_{\text {durs. }}\right)$, may be used to estimate the standard deviation of the crror of measurement. ${ }^{39}$ More specifically, if D makes no errors in measuring an anthropometric characteristic, her first and repeat measurements are equal and the difference between them is zero; but if she makes chance crrors only, her initial measurement may be larger or smaller than the repeat observation, and the difference between them will vary both in direction and size. As a result, the average or mean difference between the initial and repeat measurements of any given anthropometric characteristic will be zero, and the dispersion of the crrors can be estimated in terms of the standard deviation of the error of measurement. This standard deviation of the crror of measurement can then be added to and subtracted from the average or mean error, zero, to indicate the limits between which shightly more than two-thirds of D's errors are likely to occur. If this standard error is added to and subtrated from any single observation, the resulting seale values give the limits within which the true value of the observation is likely to occur.

Table 19 gives this estimate of the standard deviation of the error of measurement for each anthroponetric characteristic except weight and height. It may be seen that subeutaneous tissue is the most unstable, then the chest measurements and the arm girth; but the maximum standard deviation of the error of measurement for any of these six anthropometric characteristics is less than $0.5 \mathrm{~cm}$.

TABLE 19.- Standard deviations of the error of measurement of six anthropometric measurements of 50 boys and 50 girls (observer D)

Anthropometric measurement

standaril deviation of the errot of me:zurement

Irmgirth 1 (cmi)

Bi-iliac crests (width) (cm.)

Bitrochanteric width (cm.)

Chest hreadth I (cm.).

Chest depth 1 (cm.)

Subeutaneous tissue

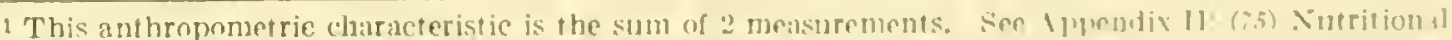
Status Indices, pp. $7-12$, for a description of $\mathrm{t}$ his measure.

39 For a description of the methor of estimating the standsed desiation of the error of measureluent. Sce Appendix 11: (7O) Palmer. np. 22:-225. 
This analysis indicates that D's measurements are unusually stable. This finding, together with the fact that her measurements agree well with those of the other observer, E, furnishes convincing evidence that $D$ is an extremely carcful and accurate worker and that her measurements are a satisfactory basis for deriving the indices included in this study.

\section{Socioeconomic and related data.}

The socioeconomic data were checked and verified by different methods, depending on the type of material and the sources available. For example, statements about illnesses were checked against hospital and clinic reports, the files of the Visiting Nurses' Association, and the records of the Divisions of Tuberculosis and Venereal Diseases of the New Haven Department of Health.

Data on income and assistance could be verified only for families who reported that they had received assistance during the ycar preceding each home visit or who were known to public or private agencies in New Haven giving direct or work relief. During the course of the study all the families with an income under $\$ 1,000$, those reporting relief assistance, families with members suffering from severe illness, and those whose income estimates appeared to be grossly inaccurate were cleared through the Social Service Exchange of New Haven. This means that the source and amount of income of these families, the number of persons living on the income, and the type and amount of assistance were checked agninst the records of the social agencies, both public and private, admmistering any form of assistance in New Haven.

School absences and progress were verified from school records.

The office clerk also checked relevant data against one another and against the files of the health and welfare agencies of the city. For example, wherever possible the birth date of the ehild as well as his legitimacy and the age of his parents were compared with the records of the Bureau of Vital Statistics of the City Health Department; other facts about the parents, with the files of the school nurses and agencies granting assistance.

Data obtained at the first home visit which did not tally with information derived from other sources were checked by the economic analysts at the second home visit.

In general, the sociocenomic data are fairly reliable and accurate. Such inaccuracies as occur are due for the most part to the failure of the mother to remember the child's history or to the fact that, as the child had previously lived in another city, records for checking were not available. Some inaccuracies have also resulted from the employment of several conomic analysts for collecting the data. Inso- 
far as possible, however, the observations were checked against one another and against the records of public and private agencies in New Haven.

\section{Summary of Material and Methods}

In the preceding pages an attempt lias been made to outline the purpose of the study and the method of collecting the observations as well as the procedures used in checking the material and editing the schedules.

Before proceeding to an analysis of these observations it may be well to review the plan and objectives of the investigation: The plan was to observe a group of 713 children living in New Haven, Conn., from September 1934 through May 1936, who were 7 years of age at the time of the second annual physical examination and were attending the public or parochial schools of the city. The purpose was to study the efficieney of each of several methods of assessing physical fitness (clinical judgment and four indices of body build) in identifying children who at 7 years of age were likely to be in poor physical condition.

The evaluation of these methods of assessing the ehild's well-being has been made in terms of the findings when the children were $T$ years old for two reasons. First, the indices of body build have been computed from measurements of the boys and girls taken at the age of 7 years, as the Nutritional Status Indiees and the ACH Index apply to 7 -year-old children and not to boys and girls 6 years of age. ${ }^{40}$ Second, if the various methods of assessment are tested on the boys and girls at 7 years of age, a whole series of clinical, anthropometric, and socioeconomic data, based on observations made over a period of 20 months, are available for evaluating the physical fitness of the children.

\footnotetext{
10 In other words, these 2 mothods are probably most cllicint in testing children of the same uge as the boys and girls from whose measurements the indices have been deriverd.
} 


\section{Results}

\section{Indices of Body Build}

\section{TIIE PROBLEM OF TESTING THE INDICES}

Two serious difficulties stand in the way of any attempt to test the four inclices of body build included in this study. The first, discussed in detail in the early part of the report, is based on the fact that none of these indices attempts to identify every child who is in poor physical condition. In fact, they measure the child's physical fitness only insofar as it is related to such characteristics as his weight, subcutaneous tissue, or arm girth. Consequently, if the indices are to be given a fair but rigorous test, it is necessary to apply them to a large group of children. The success or failure of the indices can then be measured by comparing the children they identify with the boys and girls who are likely to be in very poor physical condition.

The seleetion of such a group constitutes the second difficulty in studying these indices. It is apparent that some standard is needed for identifying children on whom the indices are to be tested, but unfortumately, as has been indicated, such a standard of physical fitness is lacking. In fact, it is this very need for a reliable moasure which meets both the statistical requirements of objectivity and reliability, and the practical requirements of umprohibitive cost. ease of application, and expediency that the indices now being studicd were designed to meet. In the true sense, then, the solution to the problem of the efficiency of these indices is indeterminate, since no entirely satisfactory criterion of refrerence is at hand.

\section{CRITERIA FOR TESTING THE INDICES}

Nevertheless, many of the factors which go to make up this complex state are known and can be measured. They can be used for deriving approximations to the true standard of physical fitness which may scrre as criteria for testing the indices. Such a procedure-namely, setting up several arbitrary but woll-defined criteria for identifying children who are likely to be physically unfit-has been adopted in this in restigation.

\section{Observations used in deriving criteria.}

Before defining the specific eriteria which have been used in this study, it may be woll to restate the material and methods and to describe some of the estimates of growth and development which 
have been used in deriving these criteria. It will be remembered (1) that during a 19- or 20-month period of observation heginning September 1934 one pediatrician examined 713 sebool children at 6 and again at 7 years of age; (2) that the physician described cach child's general nutritional status as "excellent," "good," borderline," "poor," or "very poor"; (3) that at cach physical cxamination the pediatrician indicated whether the child was in need of medical care, dental care, or both; (4) that an anthroponetrist took cight measurements when the two ammual physieal cxaminations were mate; (5) that each ehild was weighed at frequent intervals during the 19- or 20-month period of observation.

The anthroponetric measurements have been used to derive the following growth estimates:

1. The absolute increase or decrease in each anthroponetrie clanacteristir. For example, if a boy's arm girth was 33.2 ' 'm11.' at the are of 6 and 3.4 .3 ('m1. at the age of 7 , his arm girth increased approximately 1.1 cm. during the 12-month period.

2. The relative perentage increase or decrease in each of these ant hropometrie characteristics. Thus, the arm girth of this same child increased about 3.3 percent in a year $(1.1 \mathrm{~cm} / 333.2 \mathrm{~cm}.) .^{2}$

3. A more refined estimate of gain in woight. In order to determine carll child's average percentage gain in weight per month, ${ }^{3}$ an ecgnation has been fitted to his successive weighings made at frectuent intervals during the 19- (1) 20-month period of observation.* This equation measures the child's relative grain in weight much more aceurately than an estimate derived from the wo weighings made at the annual physical examinations hecanse it is based on a larger munber of measurements (five to nine) made at more frequent intervals.

Some of these data, both the clinieal observations and the growth estimates, have been used to derive provisional criteria of physical fitness which will make it possible to applaise the allecetiveness of the four indices of body build used in this study-namely, the BaldwinWood Height-Weight-Age Tables, the ACH hudex, the Nutritional Status Indices, and the Pryor Width-Wreight Tables.

\section{Description of the criterit.}

Five empirical eriterial of physieal fitness have been astablished.

Criterion $I$ is based on clinical judgment of thu child's genteral nutritional status. Any boy or girl fommel by the examining physician to be in poor or very poor eneneral mutritional condition alt 7 yars of age was "sclected" by this eriterion. (Only the boys and erits who were poorly or very poorly nomishad as distimgnished from those who

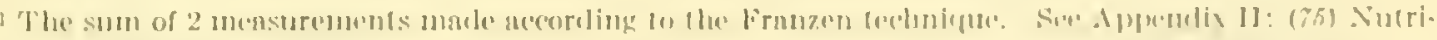
( ionul Status Incliens, pr. $7-8$.

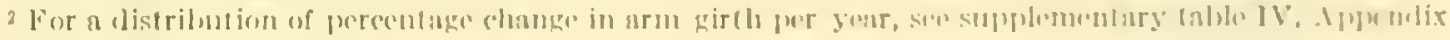
1. 1). 101 .

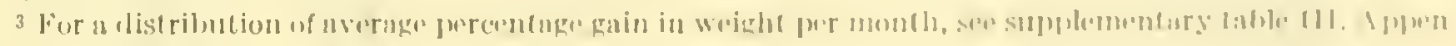
(lix I, D. 101.

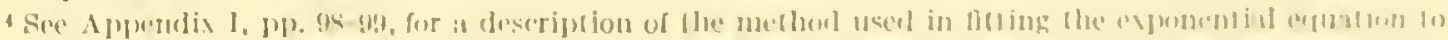
the consecutive weighings of ench child.
} 
were in a borderline state of nutrition have been used for testing the indices, on the assumption that if an index fails to select obvious cases - that is, ehildren who are in poor physical condition-it will also fail to identify children who are in borderline physical condition. Unfortunately, it is these very "borderline" children who constitute the major problem in assessing physical fitness, but until the adequacy of an index in selecting poorly nourished children is established there is no reason for testing it on a child who is in borderline nutritional condition. "Selected," as used here and as it will be used in describing the results of testing the indices, means that on the basis of a given method of evaluating physical fitness-in this case, general nutritional status at 7 years of age - a child is found to be physically unfit and is, therefore, in need of medical attention or nutritional advice and assistance.

Criterion $I I$ is a refinement of Criterion I. Any child who was found by the examining physician to be in a state of poor or very poor nutrition at 6 and at 7 years of age was selected by Criterion II.

Criteria $I I I$ and $I V$ are based on the child's average percentage weight gain and percentage change in arm girth. Although estimates were made of the increase or decrease in each of seven anthropometric characteristics of these boys and girls, only weight and arm girth have been used in deriving criteria of physical fitness. Weight has been used because it is a measurement which is easy to make accurately and because it has been carefully studied, although it has the limitation of being a three-dimensional or volumetric characteristic, which may be more closely related to the child's skeletal development than to his physical fitness. Arm girth has been seleeted not only beeause it is easily measured and the error of measurement is relatively small (table 19) but also because it reflects the child's increase in musculature and in subeutaneous tissue as well as his skeletal development. It has another advantage in its large relative variation. Next to weight and subcutaneous tissue, arm girth has the largest coefficient of variation of any of the eight anthropometric measurements included in this study. ${ }^{5}$ In other words, there is considerable variation in the

\footnotetext{
3 The coeflicients of variation for the measurements made when the boys and girls were 7 years of age are
} as follows:

\begin{tabular}{|c|c|c|}
\hline \multirow{2}{*}{ Measurement } & \multicolumn{2}{|c|}{ Coefficient } \\
\hline & Boys & Girls \\
\hline $\begin{array}{l}\text { Arm girth } \\
\text { Bi-iliac crests } \\
\text { Bitrochanteric width } \\
\text { Chest breadtl } \\
\text { Chest depth } \\
\text { IIeight. } \\
\text { Subeutaneous tissue } \\
\text { Woight }\end{array}$ & $\begin{array}{r}\text { 8. } 39 \\
5.39 \\
5.30 \\
4.77 \\
5.70 \\
4.73 \\
13.30 \\
14.02\end{array}$ & $\begin{array}{r}10.23 \\
5.59 \\
6.20 \\
5.43 \\
6.27 \\
4.16 \\
14.81 \\
16.85\end{array}$ \\
\hline
\end{tabular}


arm girth of the boys and girls which may have biological as well as clinical significance.

According to Criterion III children have been selected who exhibited an "unsatisfactory" gain in weight. If a child's arerage percentage increase in weight per month is exceeded by at least 90 pereent of the boys or the girls inchuded in this study, ${ }^{6}$ his woight gain has been arbitrarily defined as unsatisfaelory. In other words, only about 10 percent of the children exhibited an average pereentage increase in weight as small as or smaller than that of the child in question. This definition is empirical and open to criticism, but, on the other hand, it seems reasonable to assume that a child of this age who exhibits so small a gain in wejght is not in good physical condition. ${ }^{8}$

Criterion $I V$ is based on percentage change in arm girth. Any child whose percentage change in arm girth between 6 and 7 years of age was in the lowest 10 percent ${ }^{9}$ of the group of boys or girls included in the study is selected by Criterion IV. All the children identified by this criterion exhibited a percentage decrease in arn girth.

Criterion $V$ is the most restricted of the five criteria. It is a modification of two of the others and involves both elinical jurgment and growth estimates. Any child who was found by the pediatrician to be in poor or very poor nutritional condition (Criterion I) and in need of medical and dental care when examined at the age of 7 years. and who exhibited an unsatisfactory pereentage change in arm girth, as in Criterion $I V$, is selected by Criterion $\mathrm{V}$.

\section{Number of children selected by the criteria.}

The numbers of boys and of ginls identified by these five criteria vary considerably. (Table 20.) Criterion III (average relative monthly gain in weight) selects the largest number of boys, 37 (10.1 percent), and girls, 37 (10.6 pereent); Criterion $V$, based on clinical judgment of general nutritional status, need for medieal and dental care at 7 years, and pereentage change in arm girth, selects the smallest number of children, 4 boys (1.1 percent) and i) girls (1.4 percent).

\footnotetext{
o Theoretieally, the lowest 10 pereent of the children of each sex wero to be selucterl. This weull mean identifying 37 boys and 35 girls. 1Iowever, it was necessary to soleet 37 insteid of 35 girls beeause of the limitations resulting from grouping the material. All the boys who wero selected showel an average purcentage gain in weight per month of 0.657 or less; the girls, of 0.672 or loss.

: This estimate of ["reentage weight gain is a more refined mpasure than the one used in the proliminary report of this study. See Appenclix 11: (106) Sonther, Eliot, and Jenss, 11. 437.

8 Although it may woll be that an exceptionally rapuld percentage gain in weighe is us signitlentus an

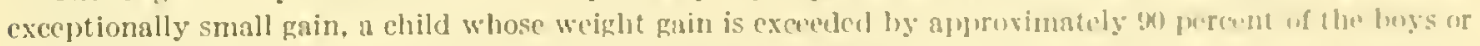
girls included in the stucly is not likely to be in very good bealth.

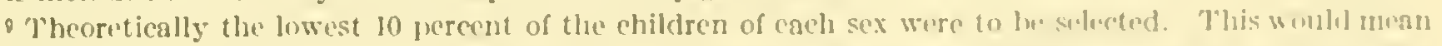

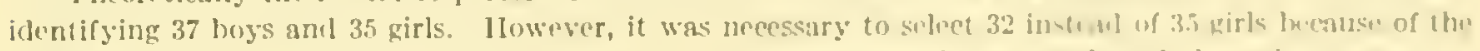
limitations resulting from grouping the data. All the children who wero selected shewel a merentago decrease in arm girtls: 1.3 or more for boys, 0.7 or mure for girls.
} 
TABLE 20.-N Number and percent of the 365 boys and 348 girls selected by each of five critcria of physical fitness

\begin{tabular}{|c|c|c|c|c|}
\hline \multirow{2}{*}{ Criterion } & \multicolumn{2}{|c|}{ Boys } & \multicolumn{2}{|c|}{ Girls } \\
\hline & Number & Pereent & Number & Percent \\
\hline $\begin{array}{l}\text { I. Clinical estinate of poor or very yonr nutritional status at } \\
7 \text { jears of age... }\end{array}$ & 28 & 7.7 & 40 & 11.5 \\
\hline $\begin{array}{l}\text { II. Clinical estimate of poor or very poor nutritional status at } \\
\text { both } 6 \text { and } 7 \text { years of age................ }\end{array}$ & 18 & 4.9 & 23 & 6.6 \\
\hline $\begin{array}{l}\text { 11I. "Unsatisfactory" } 1 \text { average percentage gain in weight per } \\
\text { month }\end{array}$ & 37 & 10.1 & 37 & 10.6 \\
\hline $\begin{array}{l}\text { 1V. "Unsatisfactory" }{ }^{2} \text { percentage ehange in arm girth per year- } \\
\text { V. Clinieal estimate of poor or very poor nutritional status at } \\
7 \text { years of age, need of hoth medical and dental care at } 7 \\
\text { years of age, and "unsatisfactory" } 2 \text { percentage change in } \\
\text { arm girth per year }\end{array}$ & 37 & 10.1 & 32 & 1.4 \\
\hline
\end{tabular}

1 The lowest 10 percent of the group of boys and girls included in the study have been considered selected by this criterion. This would mean identifying 37 boys and 35 girls. Howerer, it was necessary to select $3 \%$ instead of 35 girls because of the limitations resulting from grouping the data.

A1! the boys who were selected showed an average pereentage gain in weight per month of 0.657 or less the girls, of 0.672 or less.

${ }_{2}$ The lowest 10 percent of the group of boys and girls ineluded in the study have been eonsidered selected by this eriterion. This would mean identifying 37 boys and 35 girls. However, it was necessary to select 32 instead of 35 girls because of the limitations resulting from grouping the material.

All the ehildren who were selected showed a percentage decrease in arm girth: 1.3 or more for boys, 0.7 or more for girls.

\section{Evaluation of the criteria.}

None of these criteria is a very satisfactory measure of the child's physical fitness, although each has certain relative advantages and disadvantages. For example, the clinical examination might identify a child with flabby muscles who probably would not be selected by a growth estimate such as percentage gain in weight. On the other hand, clinical judgment does not measure dynamic aspects of the child's growth and development so accurately as growth measures based on seriatim observations of the child.

As none of these criteria is ideal and there is no valid measure to be used as a standard, the reader is left to choose for himself the criterion or criteria which he is willing to accept as a more or less satisfactory measure of physical fitness. He may, of course, find himself unwilling to accept mureservedly any one of these criteria. In that case, however, he will certainly not reject all five as without some value, since the factors on which they are based are generally known to be closely related to plyysical fitness. In other words, although the failure of an index to agree with any particular criterion may not prove that the inclex is inefficient, the reader will probably concede that its failure to agree to a considerable extent with all five methods of assessing a child's well-being justifies the conclusion that the index is not efficient in identifying (hildren who may be in need of medical attention or nutritional adrice and assistance. 


\section{TESTING THE INDICES}

Because the several indices measure different aspects of physical fitness and use different methods of identifying children who are in poor physical condition (pp. 10-17), it will be necessary to describe the association between each index and the five criteria separately.

\section{The Balduin-If ood Tables.}

It will be remembered that the Baldwin-Wood Tables gire the child's expected weight in terms of his height for his age and sex; that the child's actual weight is compared with his expected weight and the difference between them is expressed as a percentage of the expected measurement; ${ }^{10}$ and that if the observed weight is 6 or more percent less than the expected, the child is selected by this index as being underweight.

Methods of anolysis. - Before evaluating the efficiency of this index in selecting children identified by each of the five criteria, it may be well to digress for a moment for the purpose of outlining the methods used in presenting the results. The data were first analyzed in the form of "fourfold" tables (table 21), which are useful in presenting observations when the frequencies of each of the four possible combinations of two attributes are known in respect to presener or absence. To cite an example based on the Baldwin-Wood Talbles:

The girls included in this study have been classified into two groups on the basis of clinical judgment of nutrition at 7 years of age-namely, girls who were poorly or very pooris nourished (clinical judgment) and girls who were not. They have also been elassified, aceording to the Baldwin-Wood Index, into two other inclependent groups consisting of girls sclected by the index as underweight, and girls who were not. These two classifieations (based on elinical judgment of general nutritional status and on the Baldwin-Wood Index) can be further refined and interrelated to determine the number of girls who were in por or very poor nut ritional condition who were also selected by the lanldwin-Wood Index; the number of girls who were identified by the criterion (elinical judgment) bu not selected by the index; those iden iffed by the index and not selected by the criterion; and, finally, the girls selected by neither the index nor the eriterion. This type of analysis is illustrated in table 21.

According to this table the eriterion classifics only 40 of the 347 girls " as poorly" or very poorly nourished at 7 years of age; the index identifies 2.5 (62.5) perent) of these 40 ehildren as underweight for their height and age, althougl it selcets 52 other girls as underweight whom the physician did not ennsidter ponrly or very poorly nourished. In other words, although the index selects nearly twien as many ehildren as the criterion ${ }^{12}$ it fails to identify 15 (37.5 pereent) of the 40 girls whom the physician judged to be poorly or very poorty nourished.

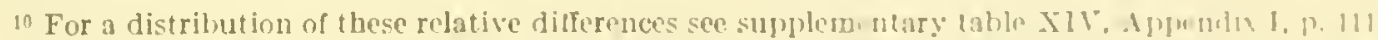

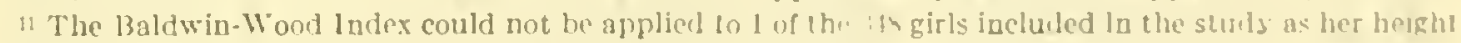
exceeded the measurements given in the Baldwin-Wood Trble

12 The index selected 72 girls; the criterion, 40.
} 
TABLE 21.-Association between clinical estimate of nutritional status and the Baldwin-Wood Tables for 347: 7 -year-old girls ${ }^{2}$

\begin{tabular}{|c|c|c|c|}
\hline \multirow[b]{2}{*}{ Clinical estimate of nutritional status } & \multicolumn{2}{|c|}{ Baldwin-Wood Tables } & \multirow[b]{2}{*}{ Total } \\
\hline & $\begin{array}{c}\text { Selected as } \\
\text { under- } \\
\text { weight } 3\end{array}$ & $\begin{array}{l}\text { Not se- } \\
\text { lected }\end{array}$ & \\
\hline $\begin{array}{l}\text { Poor or very poor } \\
\text { Other }{ }^{4}\end{array}$ & $\begin{array}{l}25 \\
52\end{array}$ & $\begin{array}{r}15 \\
255\end{array}$ & $\begin{array}{r}40 \\
307\end{array}$ \\
\hline Total _. & 77 & 270 & 347 \\
\hline
\end{tabular}

1348 girls were included in the study, but the index could not be tested on 1 girl whose height exceeded the measurements in the table.

2 For the Baldwin-Wood Tables age at nearest birthday was used; at the physical examinations age was defined in completed years.

36 percent or more underweight

4 "Other" included children whose nutritional status was estimated as excellent, good, or borderline.

This method of analyzing the data (in the form of fourfold tables) may be condensed ${ }^{13}$ for inclusion in the table which gives the results of testing the index (table 22) to show the number of children selected by each of the five criteria, the number identified by the index, and the number selected by both the criterion and the index. This table also gives the children identified by both the criterion and the index as a percentage of those selected by the criterion and shows the percentage of the boys or girls included in the study who must be screened by the index to include all the boys or girls identified by each of the criteria.

In interpreting the results of testing this or any other index, it should be remembered that to be effective as a method of assessment, an index must have both specificity and sensitivity. If an index is specific, every child who is selected is in poor physical condition but not every child who is in poor physical condition is necessarily selected. On the other hand, if the index is sensitive, it will identify all the children who are in poor physical condition, but not every child it selects is necessarily physically unfit. To put it in another way, there are two requirements which a satisfactory index must fulfill. When applied to a group of children, it must pick out all or nearly all the children who are in poor physical condition, and in addition it must reject all or nearly all the children who are physically fit. Does the Baldwin-Wood Index meet these requirements? This question will be answered for each of the 5 criteria.

${ }_{13}$ It is impor tant to point out that the original fourfold table used in testing the index can be derired from the summary tahles. For example, according to table 22 there were 347 girls on whorn tho inder was tested. Criterion I selected 40 girls; the index identificd $77 ; 25$ girls were seleeted by both the criterion and tle index, and 15 girls identified by the criterion were not selected by the inclex. Similarly, 52 girls identified by the index were not selected by the criterion. Now, if the index identified 77 girls and it was testerl on 347 , it necessarily follows that the index did not select 270 girls. Similarly, if the criterion identifler 40 girls it failed to select 307; and finally, if 307 were rejected hy the criterion of whon 52 were selected by the index, 255 were rejectod by both the eriterion and the index. These olservations form all tho necessary data for comploting the fourfold table which shows tho association between Criterion I and the Baldwin-Wood Index. 


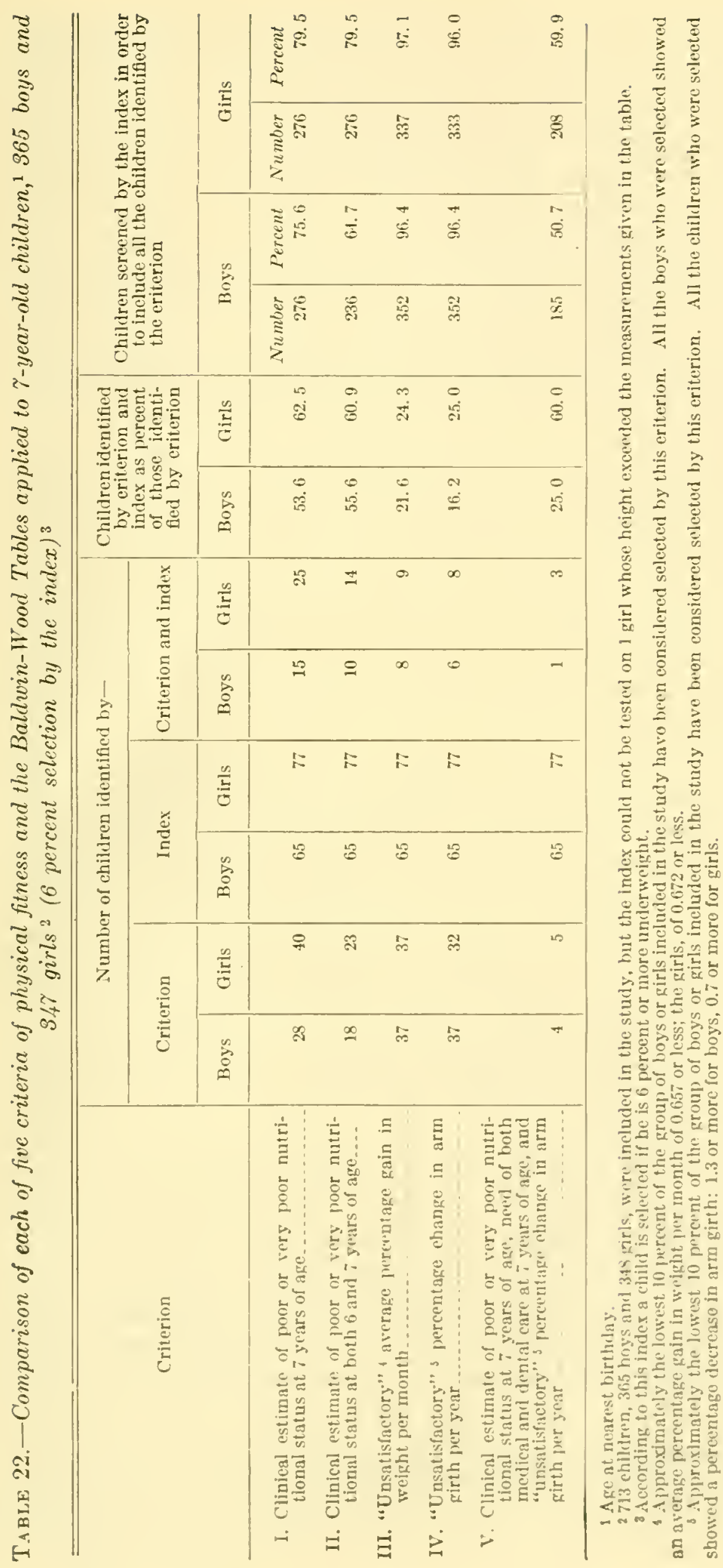


Criterion I.- It may be seen from table 22 that the Baldwin-Wood Index identified as 6 or more pereent underweight 77 of the 347 girls on whom it was tested; that Criterion I (clinical judgment) selected 40 girls as poorly nourished and that only 25 girls were identified by both the eriterion and the index. In other words, of the 40 girls whom a competent physician judged to be poorly nourished at 7 vears of age, 25 , or approximately 62 percent, were identified by the Baldwin-Wood Index as being 6 or more percent underweight. It follows that 52, or approximately 68 percent, of the 77 girls identified by the Baldwin-Wood Index were not poorly nourished according to the physician's judgment and that 15 , or approximately 38 percent, of the 40 girls who were selected by the physician were rejected by the index.

In interpreting these results it is appropriate to refer to a question asked by A. Bradford Hill in diseussing R. Huws Jones' paper, "Physical Indices and Clinical Assessment of the Nutrition of School Children," read before the Royal Statistical Society in London on November 16, 1937. Hill asked: "If the test fails to pick out certain boys elinically assessed as bad or picks out certain others clinically assessed as good, is it because the test is bad or the clinieal assessment is bad?" 14

In order to minimize the error's inherent in elinical judgment, all the physieal examinations of the children included in this study were made by one well-trained pediatrieian and included the evaluation of many factors commonly agreed upon to be basic elements in physical fitness. Furthermore, the stability and reliability of her clinical findings have been investigated and found to be as objective as can reasonably be expected. ${ }^{15}$ If, then, her judgment is accepted as a more or less satisfactory criterion of physical fitness, one may conclude that (1) the Baldwin-Wood Index failed to identify nearly 40 pereent of the girls who were poorly nourished, and (2) more than two-thirds of the girls it selected were not physically unfit according to the physician's judgment.

The index was even less efficient in identifying boys selected by this eriterion (clinieal judgment). Only 15, or about 54 pereent, of the 28 boys whom the pediatrician judged to be poorly nourished were identified by the index; while 50, or approximately 77 percent, of the 65 boys who were seleeted by the index were not identified by the criterion. In other words, the Baldwin-Wood 'Tables are not an efficient index if clinical judgment is used as a standard of physical fitness.

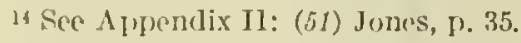

${ }^{15} \mathrm{~A}$ detailed disenssion of the stability and reliability of the pediatrician's judgment is presented on I). $32-87$. 
The Baldwin-Wood Tables have been tested in another way by determining the number and percentage of the boys or girls who must be screened by the index in order to identify all the children selected by the criterion. For example, according to Criterion I, 40 girls were identified as poorly nourished (by clinical judgment) at 7 years of age. If, as has been pointed out, the Baldwin-Wood Index is set to identify girls who are 6 or more percent underweight, it selects only 25 , or about 62 percent, of these 40 girls. On the other hand, if the index is required to select all the 40 children whom the pediatrician judged to be physically unfit, it will also identify 236 girls whom the pediatrician did not select, a ratio of about 1 to 6 . If a similar test is made for the 365 boys included in the study, the ratio is approximately 1 boy who was poorly nourished to every 10 who were not. This evidence confirms the previous findings and demonstrates even more clearly the low sensitivity of the index in identifying the group of New Haven children included in this study, if it is tested in terms of clinical judgment.

Criterion II.-Children identified by Criterion II were judged by the pediatrician to be in poor or very poor nutritional condition at 6 and also at 7 years of age. This criterion is theoretically a more rigorous test than Criterion I, for although they are both based on clinical judgment of general nutritional status, Criterion II refers to both physical examinations (that is, the examinations made at 6 and again at 7 years of age) while Criterion I applies only to the findings at 7 years (table 22). According to this table the Baldwin-lFood Index identified about 56 percent of the 18 boys and about 61 percent of the 23 girls selected by the criterion. In other words, it failed to identify nearly half the children selected by the criterion as poorly or very poorly nourished at both 6 and 7 years of age. If one considers the additional fact that 63 , or about 82 percent, of the girls and 55 , or about 85 pereent, of the boys who were identified by the index were not selected by the criterion, it is quite clear that the BaldwinWood Tables are neither a selective nor a sensitive measure of the physical fitness of the boys and girls included in the study, if elinical judgment at both 6 and 7 years of age is used as a criterion.

Criterion III.-The Baldwin-Wood Index identified only about 24 percent of the 37 girls and about 22 percent of the 37 boys whose weight gain was unsatisfactory (Criterion 1ll). ${ }^{16}$ In interpreting these results it should be remembered that (1) the weight-gain estimates are exceptionally accurate, for they are based on an arerage of eight weighings malc over approximatrly a 2-year period; (2) about

\footnotetext{
16 'These estimates of average rolative gain in woight fur munth are prohnlul mure accurnte than the

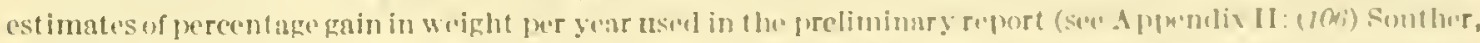
Eliot, and Jenss, p. 437). ('onsoruently the results of testing the indices in terms of these a forms of the criterion are not ctrictly comparable.
} 
90 percent of the boys and of the girls included in the study exhibited a larger average pereentage increase in weight per month during the 19- or 20-month period of observation than the boys and girls selected by the critcrion; and (3) these children were probably in poorer physical condition than the boys and girls whose weight gain was more satisfactory, although not all children who are in poor physical condition necessarily exhibit a small weight gain. As has been pointed out, however, the Baldwin-Wood Tables identified only about 20 to 25 percent of the boys and girls selected by this criterion. If the inclex is set to identify all the boys and girls who exhibited an unsatisfactory weight gain, it would identify about 96 percent of the boys and about 97 percent of the girls included in the study. In other words, practically all the children would have to be selected by the index if it is to identify the small number whose weight gain was unsatisfactory.

Criterion $I V$.- This criterion, percentage change in arm girth, ${ }^{17}$ has none of the virtues which result from widespread application and study such as the weight-gain estimates have. It has been used in this investigation, however, because it has the probable advantage, in comparison with weight-gain estimates, of not being influenced to the same extent by the child's skeletal development. In addition, the percentage change in the arm girth of these children varied considerably. The range for boys was from a decrease of 6.3 percent per year to an increase of 21.6 percent, with a mean increase of 3.12 percent and a standard deviation of 3.58 percent. Corresponding figures for the girls are as follows:

\section{Percent}

Range
Mean
Standard deviation

In other words, the variation in this growth estimate is large enough to assume biological and perhaps clinical significance, for there are some indications that marked changes in a child's physical well-being are often reflected in his arm girth. It is for these reasons that percentage change in arm girth has been used, as Criterion IV, for identifying boys and girls who are likely to be in need of medical attention or nutritional advice and assistance.

For the application of this criterion, the boys and girls were each grouped in order of percentage change in arm girth per year. Then the children who were in approximately the lowest 10 pereent of each group were arbitrarily selected, as showing an unsatisfactory percentage change in arm girth (a decrease of 1.3 or more percent for boys and 0.7 perecnt or more for girls) between 6 and 7 years of age.

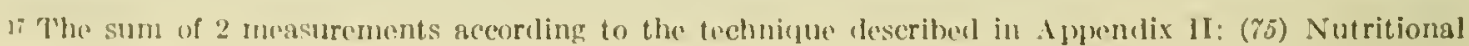
stutus Intions, on. $7-x$.
} 
The Baldwin-Wood Index identified only about 16 pereent of these 37 boys and 25 pereent of the 32 girls who were selected by the eriterion. If the index is required to select all these children who showed an unsatisfactory change in arm girth, it must identify about 96 percent of the boys and the same percentage of the girls included in the study.

Criterion V.-The limitations of each of the four criteria which have been studied are well recognized. Two of these criteria are entirely dependent on clinieal judgment; the other two are dependent on growth estimates. It was, therefore, decided to employ a criterion (Criterion V) which involves both elinical judgment and estimates of growth, and, in addition, includes the physician's judgment of the child's need for medical and dental care. In order to make the test very rigorous, the following requirements for selection by the criterion were made: (1) The child's gencral nutritional status was judged by the pediatrician to be poor or very poor at 7 years of age; (2) the child needed both medical and dental care at the age of 7 years when the pediatrician made the physical examinations; and (3) each child was in approximately the lowest 10 pereent of the group of boys or girls included in the study with respect to percentage change in arm girth between 6 and 7 rears of age.

As would be expected, only a small number of ehildren-4 of the 365 boys and 5 of the 347 girls-on whom the index was tested, were selected by this criterion. Examination of their anthropometric schedules, physical examinations, medical histories, and socioeconomie schedules indicates that these 9 children were in very poor physical condition. Yet the index failed to identify 3 of the 4 boys and 2 of the 5 girls. If it does not select these children who are extreme cases, will it identify other boys and girls who are physically unfit?

\section{The ACH Index.}

The next index to be tested is the ACH Index. It is based on an empirical procedure developed by the American Child Health Association for identifying children with a small amount of musculature and subcutaneous tissue relative to body build. According to this procedure a child may be selected as falling in the lowest 10,14, 20, or 25 pereent of a group of boys or girls of the same age and hip width. Such selection is dependent on the difference between the child's arm girth and his chest depth relative to his hip width. In order to make the results of testing this index roughly comparable to the findings which pertain to the Nutritional Status Indices and to the Pryor 'Tables, each of which has been arbitrarily set to identify the lowest 15 pereent of a latege group of boys and girls, the AC'II Index has been set to select the lowest 14 pereent of a group of children of the same 
sex, age, and hip width. ${ }^{18}$ At this level only 9 of the 712 children ${ }^{19}$ on whom the index was tested, 4 boys (1.1 percent) and 5 girls (1.4 percent), were identified by the index.

According to table 23 the ACH Index does not agree very well with any of the five criteria. When the index was tested on the girls, there was maximum agreement (10.0 pereent) with clinical judgment of nutritional status at 7 years (Criterion I). On the other hand, for three of the eriteria-namely, unsatisfactory weight gain (Criterion III), unsatisfactory change in arm girth (Criterion IV), and Criterion $\mathrm{V}$, based on clinical judgment and need for medical and dental care at 7 years of age as well as unsatisfactory change in arm girth-none of the girls selected by the criterion were identified by the $\mathrm{ACH}$ Index. It was somewhat more efficient in identifying boys, but the maximum agreement was only 25 percent (Criterion V). ${ }^{20}$ In other words, evidence derived from this study indicates that the index is not sufficiently sensitive because it identified so small a number of children. In terms of the five criteria used in this study, it is also not a highly selective procedure.

\section{The Nutritional Status Indices.}

The three Nutritional Status Indices utilize the principle of comparing (1) weight; (2) muscle size as indicated by the girth of the upper arm; and (3) amount of subcutaneous tissue over the biceps with the child's expected weight, arm girth, or subcutaneous tissue judged in relation to his sex, age, and body build measured in terms of his height, chest depth, chest breadth, and hip width. The method of computing and evaluating the child's relative standing, or "score," in any one of these three anthropometric measures is described in the monograph, Nutritional Status Indices. ${ }^{21}$ Table $\mathrm{X}$ of that publication gives the child's score and his relative standing in a group of his skeletal peers of the same sex and age, ${ }^{22}$ but the authors do not give instructions for interpreting the significance of the child's standing in terms of his physical fitness. Neither is there a definite statement in the monograph concerning the relative value of each of the three indices. In order, therefore, to test the indices in terms of their agreement with the five criteria, it was necessary to make the following

\footnotetext{
18 Supplementary table V, Appendix I, p. 102, tests the index set to seleet 20 instead of 11 pereent of the chillren. It may be seen upon examination of this table that the results agree in general with those presented in table 23.

19713 ehildren were included in the study, but the index could not be tested on 1 boy whose bitrochanteric willth was unknown.

20 The ACII Index does not permit analysis to determine the percentages of the ehildren sereened by the index in order to seleet all the ebildren identified by a criterion.

21 See Appendix II: $(75)$ Nutritional Status lndiees, Jp. 14-18.

${ }_{22}$ The Nutritional Status Indices were construeted to show the mumber of children in 1,000, but in this monograph the number of children in 100 is used in order to present the results in percentage form.
} 


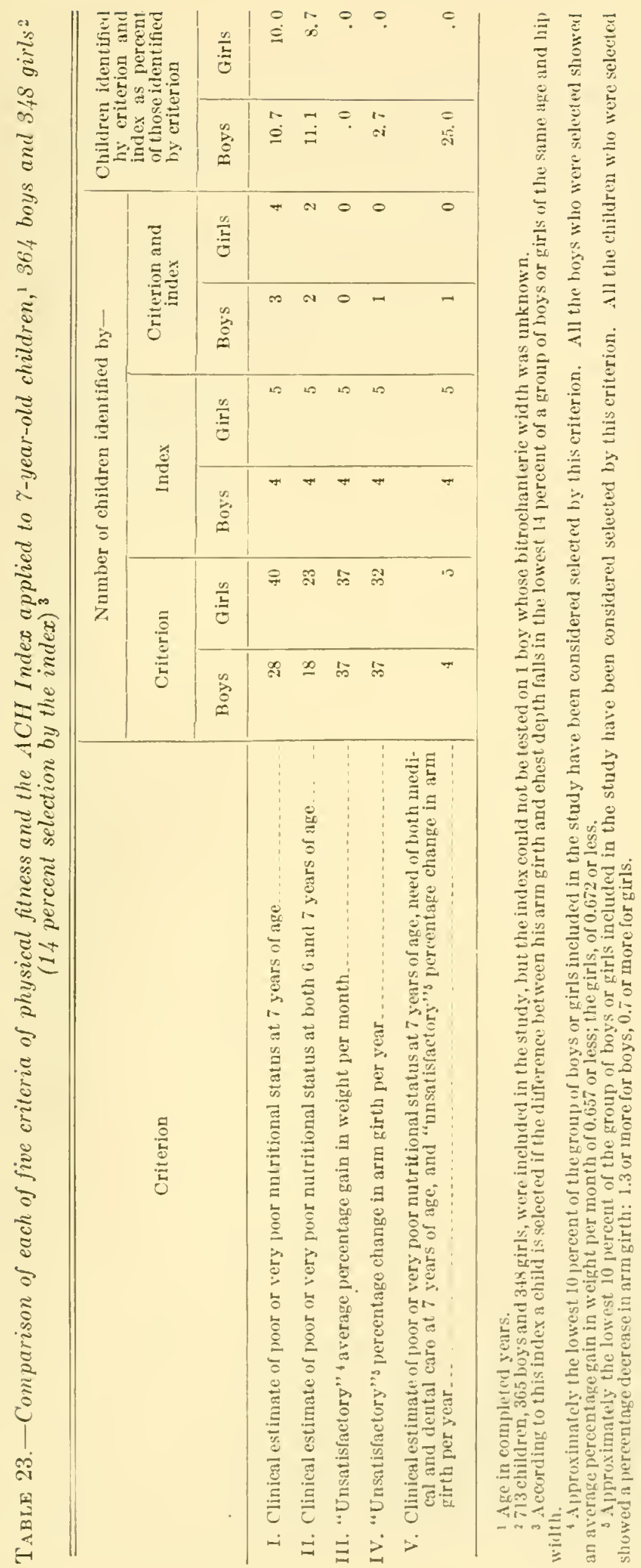


arbitrary decisions about both the child's score and the three Nutritional Status Indices:

1. A child has been considered selected by any one of these three indices if his score shows him to be in the lowest 15 pereent of a group of his skeletal peers of the same sex and age as shown in Table $\mathrm{X}$ of the monograph, Nutritional Status Indices. ${ }^{23}$

2. Each index and every possible combination of the three indices have been used in comparing the Nutritional Status Indices with the criteria. (a) The weight index; (b) the index for arm girth; (c) the index for subcutancous tissue; $(d)$ the indices for weight and subcutaneous tissue; $(e)$ the indices for weight and arm girth; $(f)$ the indices for arm girth and subcutaneous tissue; and $(g)$ the indices for weight, arm girth, and subcutaneous tissue have been compared with each of the five criteria.

The results of testing these indices are given in tables 24 to 30 , inclusive.

\footnotetext{
${ }^{33}$ Sec pl). 14-16 for methorl of computing score.
} 


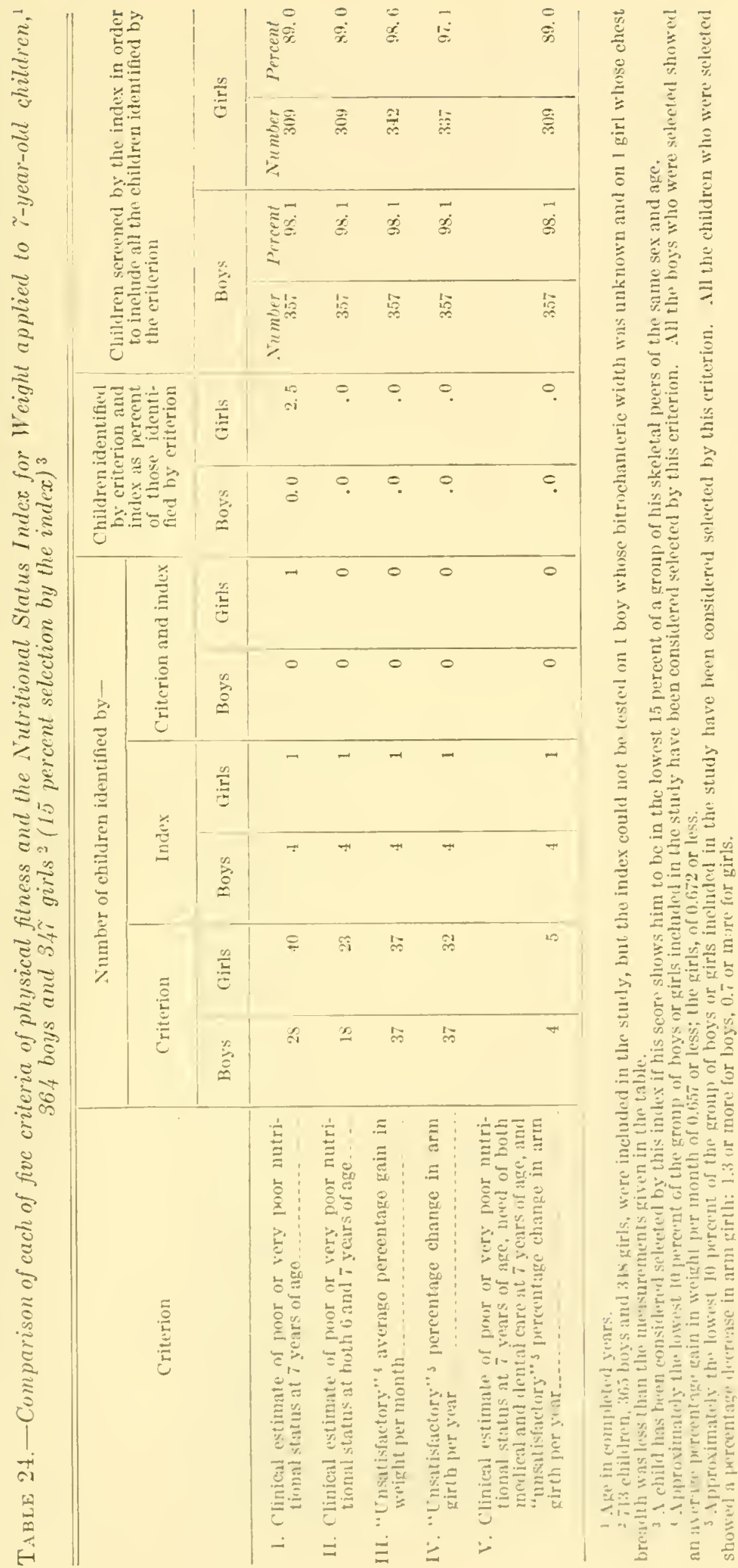




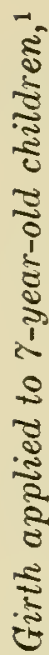

\begin{tabular}{|c|c|c|c|c|c|}
\hline है & 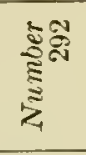 & హ్ & 简 & ש్ & $\varrho$ \\
\hline & 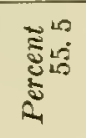 & 10 & 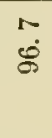 & זे & $\begin{array}{l}\infty \\
\dot{\rho} \\
\dot{\rho}\end{array}$ \\
\hline ฉి & 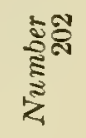 & జ్ & 品 & 品 & $\overrightarrow{\mathfrak{m}}$ \\
\hline
\end{tabular}

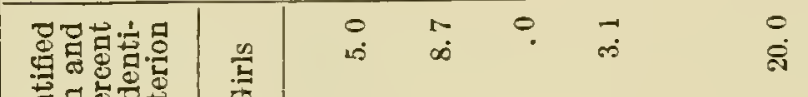

항

ฐ્.

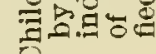

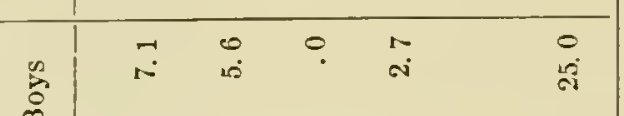

$\Xi$

$\stackrel{8}{ت}$

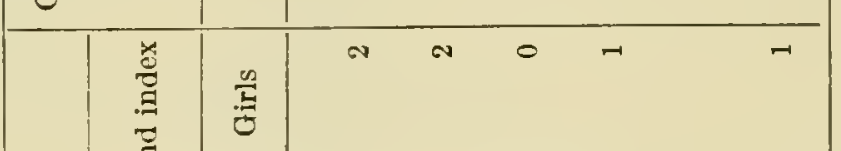

ज.

苛芯

플

‡

ह

$\approx 20$

ङิ

$\sin \frac{2}{3} \cdot \frac{2}{3}$

혼?

$\overrightarrow{\tilde{E}}$

ตี้

용

달
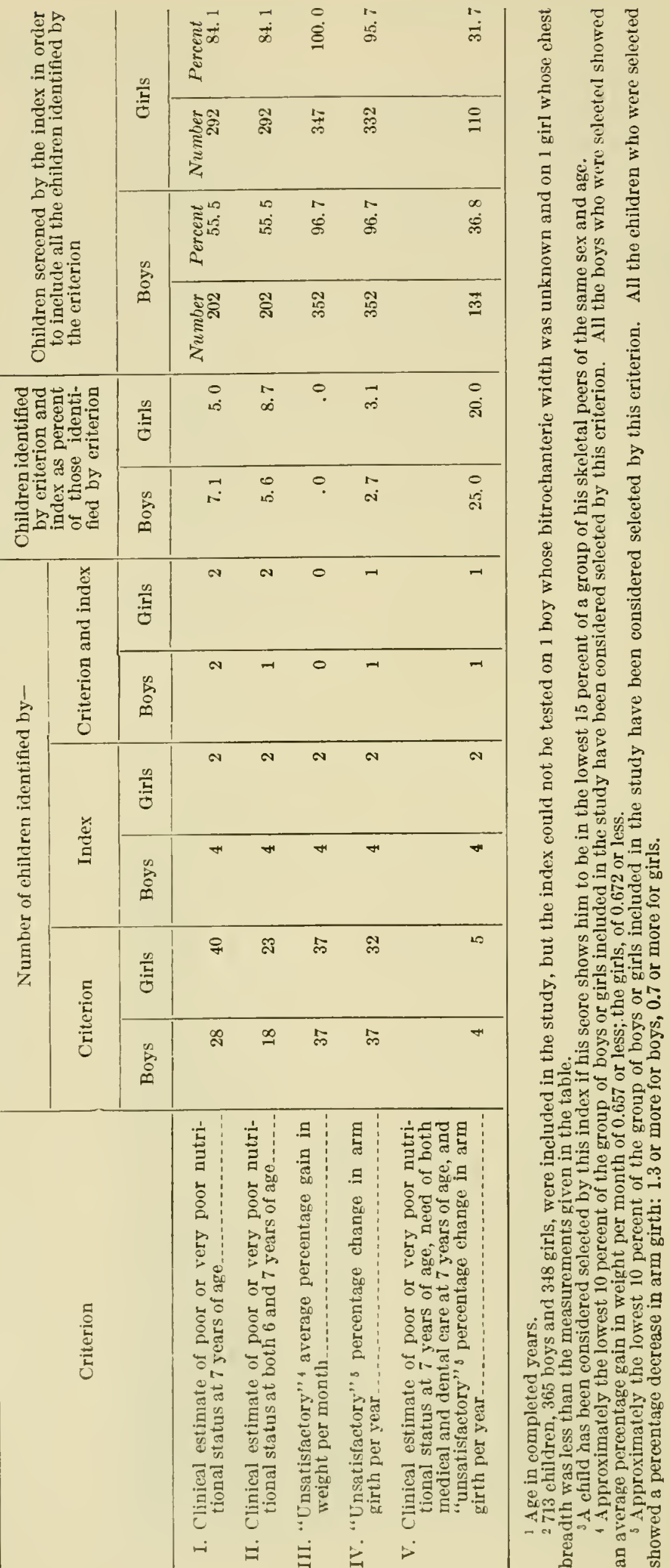


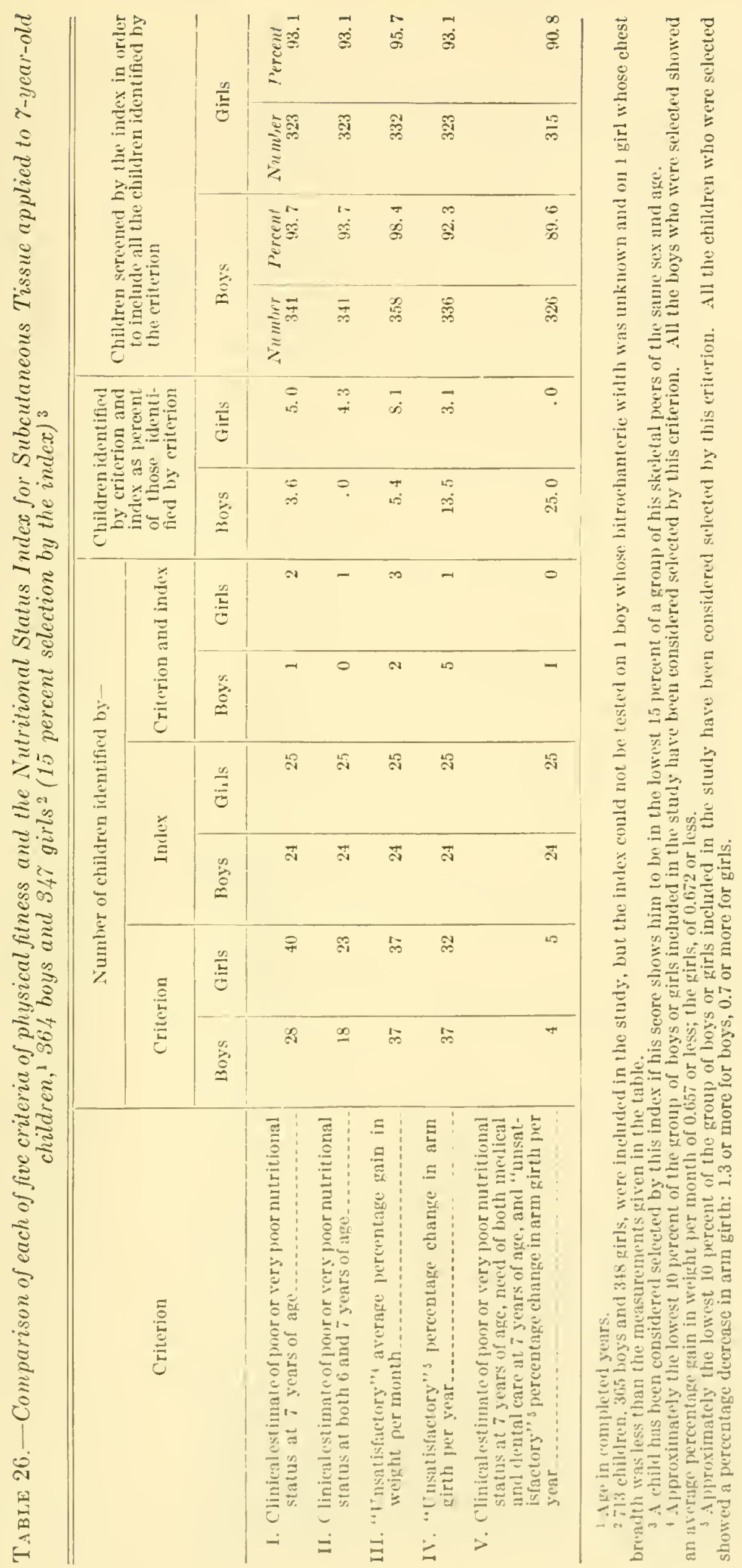




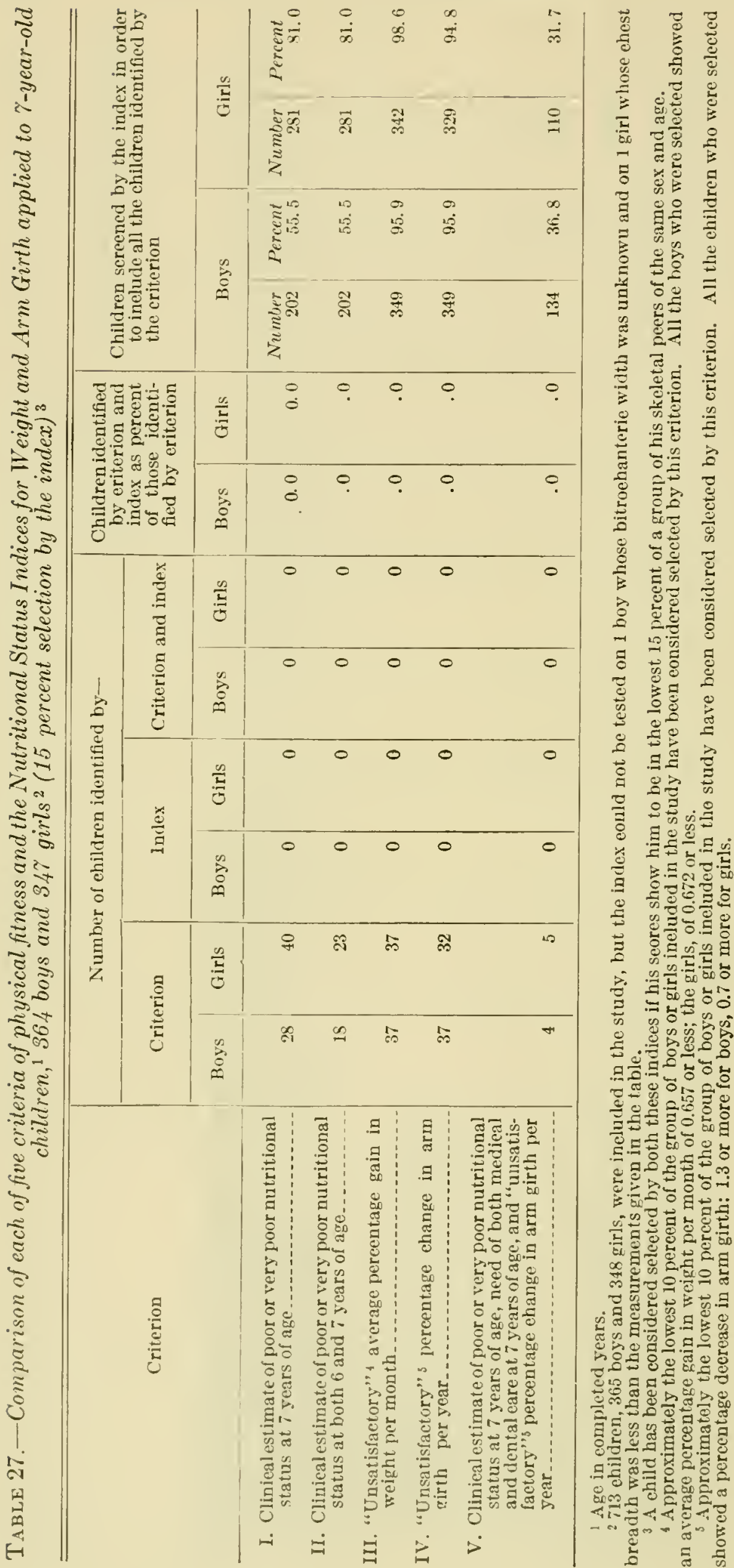




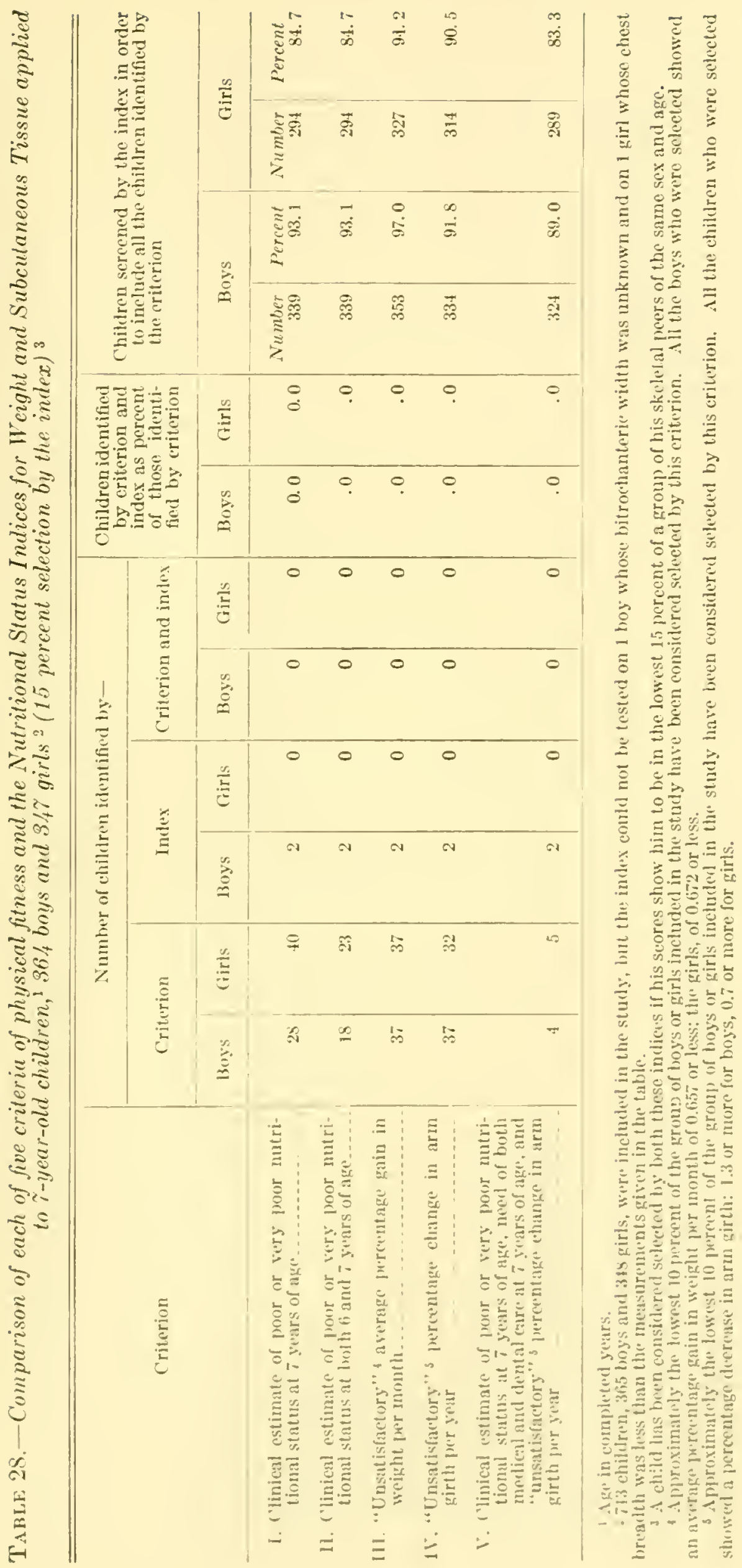




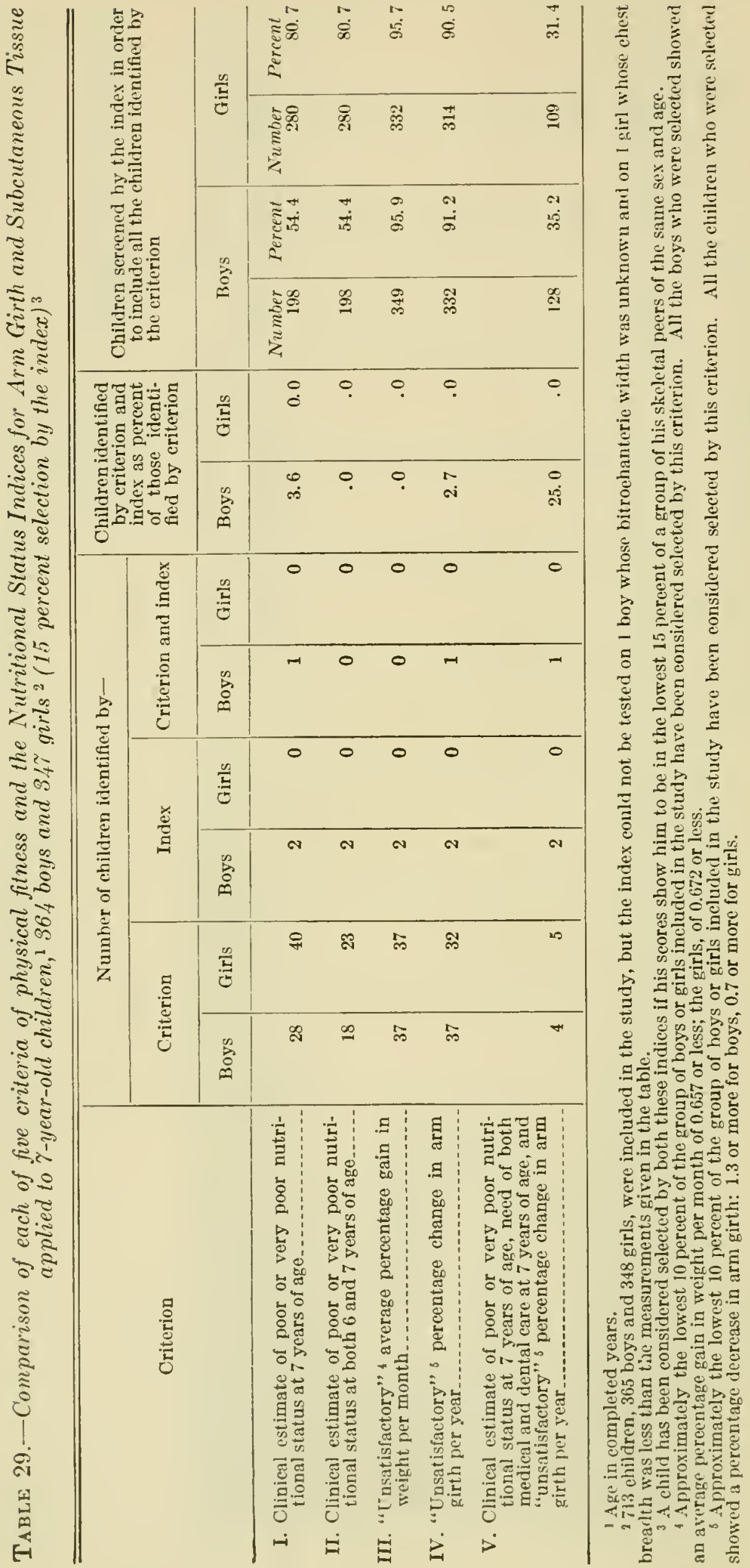




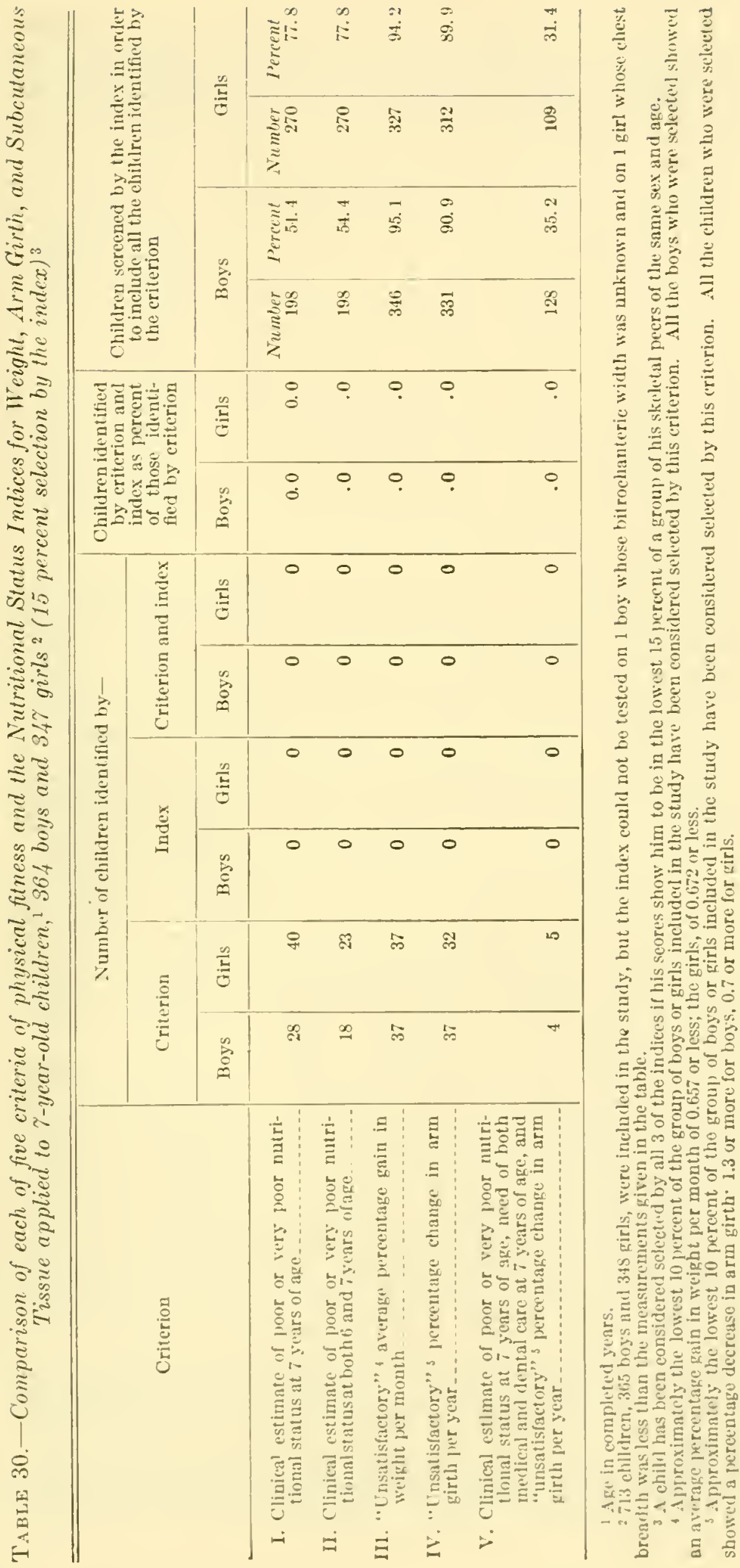


Examination of these tables permits the following broad generalizations: (1) There is some variation (from zero to 7.2 percent) in the number and percentage of boys and girls who were identified by each of the Nutritional Status Indices or by any combination of these indices:

\begin{tabular}{|c|c|c|}
\hline \multirow{2}{*}{ Nutritional Status Index } & \multicolumn{2}{|c|}{$\begin{array}{l}\text { Number of children } \\
\text { selceted by the index }\end{array}$} \\
\hline & Boys & Girls \\
\hline Weight & 4 & \\
\hline & $\begin{array}{r}4 \\
24\end{array}$ & 25 \\
\hline $\begin{array}{l}\text { Subcutaneous tissue } \\
\text { Weight and arm girth } \\
\text { Weight and subcutancous tissuc }\end{array}$ & None & None \\
\hline \multirow{2}{*}{$\begin{array}{l}\text { Weight and subcutancous tissue } \\
\text { Arm girth and subcutaneous tissue }\end{array}$} & 12 & None \\
\hline & 12 & None \\
\hline Weight, arm girth, and subcutaneous tissue & None & \\
\hline
\end{tabular}

I The 2 children identificd by both weight and subcutaneous-tissue indices were not identified by the armgirth and subcutaneous-tissue indices.

(2) Probably the only index that identifies a sufficient number of children to justify a detailed comparison with any of the five criteria is the Nutritional Status Index for Subcutaneous Tissue, which selects 24 boys and 25 girls out of the 364 boys and 347 girls on whom the index was tested. It is surprising that so few children were selected by the other six indices. Although no attempt has been made to determine the reasons why the indices failed to identify more children, there is some evidence that the Nutritional Status Index for Weight and the Index for Arm Girth do not satisfactorily describe New Haven boys and girls. According to Table $\mathrm{X}$ of the monograph, Nutritional Status Indices, the scores of any large group of children tested by either of these two indices should be distributed according to the normal probability curve, with a mean or average score of 50.0 and a standard deviation of 10.0 .

If a frequency distribution is marle of the weight or arm-girth scores of the boys and girls included in this study, the distribution is not normal, the mean is not 50.0, and the spread of the scores, as measured in terms of their standard deviation, is not 10.0. ${ }^{24}$ In fact, the whole curve is shifted to the right and is skew in the positive direction. ${ }^{25}$

The reason for these differences is not known because the Nutritional Status monograph does not describe the 7-year-old children whose measurements were used in deriving the indices. It may be

\footnotetext{
24 The mean and the standard deviation can be translated into xi values of 0 and 1. respectively. Seo supplementary tables XV, XVI, and XVII, A ppendix I, pp. 111-112, which give thoobserved values of the mean and the standard deviation of the distributions of the Nutritional Status Indices for the New Haven children includerl in this sturly.

23 A personal communication from 1)r. C. F. l'almer, U. S. l'uhlic Ilealt Service, states thut the Nutritional Status scores for IIagerstown school children also fail to approximate the normal crror curve. See A ppendix Il: (81) l'alner.
} 
said, however, that the New Haven children included in this study form a selected group ${ }^{26}$ and that the majority represent two quite distinct nationality groups. About 46 percent of the children were Italian, ${ }^{27}$ and approximately 18 pereent were American boys and girls. This large proportion of Italian children may partly explain the failure of the indices to identify 7 -year-old New Haven boys and girls, but, whatever the reason, the number of boys and girls selected by the weight or the arm-girth index is so small that the value of the index is immediately subject to question.

In table 26, which presents the results of testing the Nutritional Status Index for Subcutancous 'Tissue, it is found that although this index identified 24 boys and 25 girls, it selected only a small percentage of the children identified by any of the five criteria. Indeed, the maximum agreement between this index and the criteria was only 25 pereent. When the index is tested in terms of the percentage of the boys or girls who must be serecned in order to idcntify all the children selected by a criterion, the minimum is almost 90 pcrcent. In other words, there can be little doubt concerning the low selectivity and sensitivity of the Nutritional Status Index for Subcutancous 'Tissue in assessing the nutrition of these New Haven boys and girls.

To summarize:

1. The Nutritional Status Indices, either singly or in combination, failed to select most of the children identified by any of the five eriteria.

2. The maximum agreement is 25 pereent for Criterion $\mathrm{V}$.

3. The maximum agreement for any of the other four criteria is only about 14 percent.

4. In 50 (71.4 pereent) of the 70 tests (five criteria for cach of the seven Nutritional Status Indices for the two sexes) in which the cliildren identified by the Nutritional Status Indices (tables 24-30, inclusive) were compared with the boys and girls selected by the five criteria, the index failed to identify a single child who was selected by a criterion.

5. If any of these indies is set to select all the children identified by any one of the eriteria, the minimum number of childen which the index must select in order to inchude all the children identified by any of the criteria is about 31 perent; the maximum, 100 pereent; and the average, about 81 percent. In other words, there is considerable evidence that the Nutritional Status Indices are neither selective nor sensitive if any one of the five eriteria used in this study is accepted as an approximate standard of physical fitncess. ${ }^{2 n}$

\footnotetext{
28 See pp. 27IT. for deseription of the ehilelen incluterl in this sturly.

29 For definition sce p. 25.

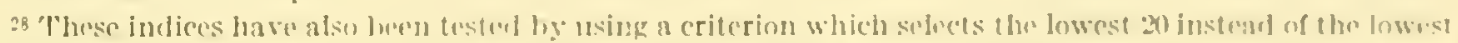

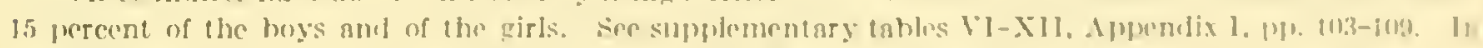
general these tables confrum the findinas haser on the selecthon of the lowest is percent of the children.
} 


\section{The Pryor Width-Weight Tables.}

The Pryor Tables are logically an elaboration of the Baldwin-Wood Tables which estimate a child's weight for his sex, age, and height. The Pryor Tables take one more variable into account in evaluating a child's expected weight; namely, his bi-iliac diameter. In other words, they use two variables (height and width of the iliac crests) instead of only one (height) in judging weight.

Although the instructions for using these tables do not prescribe a method of selecting boys or girls who may be underweight or of comparing a child with other boys and girls of the same age, sex, and body build, Pryor has approved the use of a procedure which approximates the one used by Franzen and his coworkers in deriving the Nutritional Status Indices. It utilizes the principle of subtracting the child's expected weight from his observed weight and expressing this difference in terms of the standard deviation of the regression equation for weight on height and width of the iliac crests. ${ }^{29}$ It has been arbitrarily decided that a child is selected by the Pryor Index if his relative standing or score by this method of scoring shows him to be in the lowest 15 percent of a group of his skeletal peers of the same sex and age. ${ }^{30}$

With this selection point in use, the Pryor Tables have been compared with each of the five eriteria. (Table 31.) It may be seen from this table that there was not a close agreement between the index and any of the criteria. The maximum agreement was 32.1 percent; the minimum, 10.8 percent. If the index is set to include all the children selected by the criteria, the minimum percentage identified by the index is 67.7 percent; the maximum, 97.5 percent.

One would expect this index to be as satisfactory as the BaldwinWood Tables, but it must be remembered that (1) the New Haven children on whom the index was tested may include a larger percentage of Italian boys and girls than the children whose measurements were used in deriving the Pryor Tables; and (2) these tables are an elaboration of the Baldwin-Wood standard, in terms of the widths of the iliac crests of a group of California boys and girls who may not be comparable to the children included in the Baldwin-Wood Tables. But whatever the reason or reasons, the Pryor Index is not an entirely satisfactory method of identifying New Haven children of this age who may be physically unfit.

20 See Appendix I, pp. 97-98, for a detailed description of this method. Sce also supplementary table XVIII, Appendix I, 1) 112, for a distribution of the $x / \sigma$ values of the Pryor Index for the boys and girls included in this sturly.

30 'the index has also been set to seleet the lowest 20 percent of the children. See supplementary table XIII, Appendix I, p. 110. 


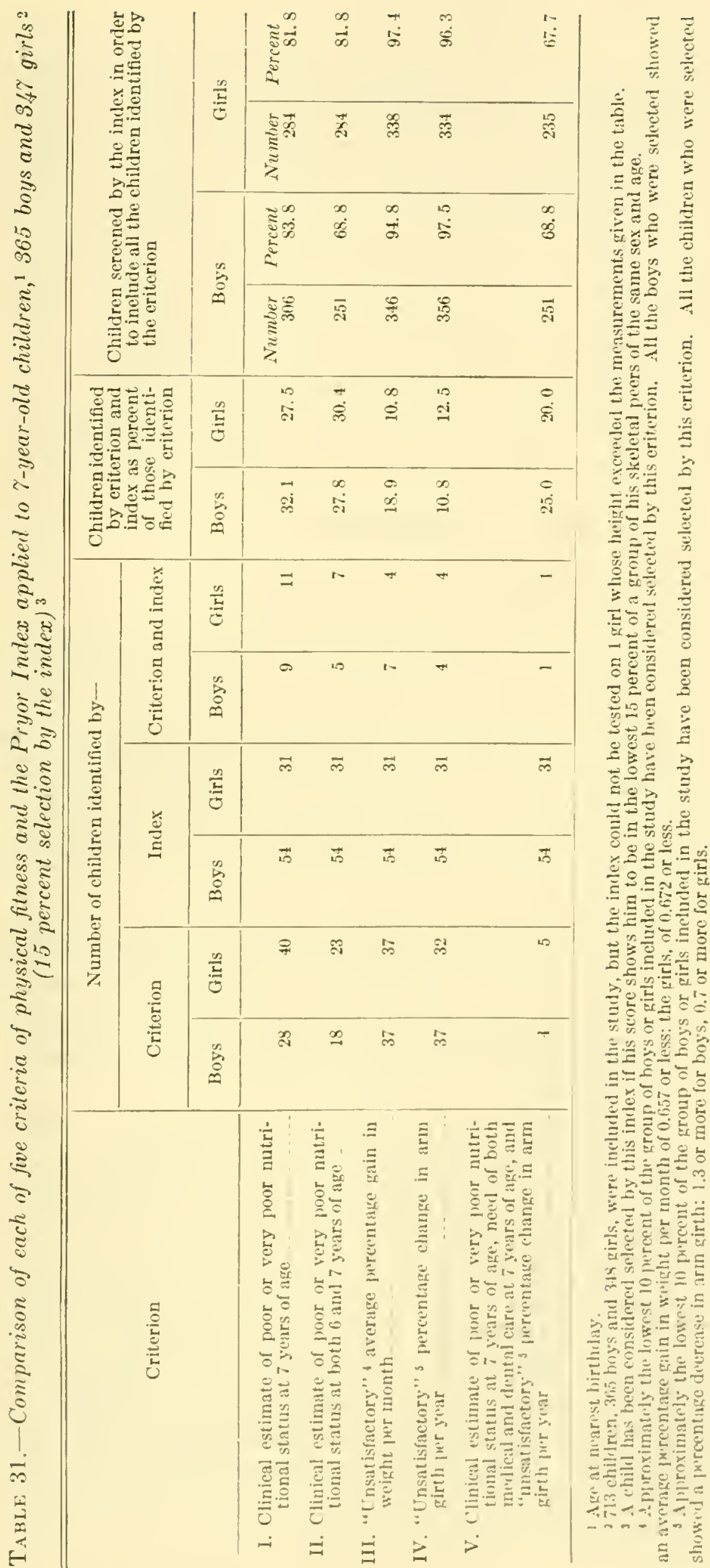




\section{SUMMARY}

Although the four indices included in this study-namely, the Baldwin-Wood, the ACH, the Nutritional Status, and the Pryor Indices-differ so markedly in type that it would be manifestly unfair to compare their performance, one fact emerges clearly from the study: There is little agreement between these four indices and any of the five criteria. None of these criteria is an entirely satisfactory standard, but the failure of the indices to identify a considerable proportion of the children selected by all five criteria together with the identification by the indices of an even larger number of boys and girls who were rejected by the criteria means that the indices are probably neither a selective nor a sensitive method of assessing the physical fitness of the 7-year-old New Haven children included in this study.

\section{Clinical Judgment}

\section{THE EXPERIMENTAL DATA}

As has been stated (p. 45), it is important to determine both the objectivity and the stability of the clinical judgment of the pediatrician designated as " $A$ " who made all the physical examinations during both years of the study. In order to investigate this problem, 208 children (107 boys and 101 girls) ${ }^{31}$ were included in a series of check-up examinations which were made in March and April 1936 after the tests and examinations of the children at the age of 7 years were completed.

These check-up examinations may be discussed under two headings: (1) Examinations of each of the 208 children by three pediatricians, $A, B$, and $C$, in order to study the variability of clinical judgment of general nutritional status; and (2) recxamination of 103 (51 boys and 52 girls) of these 208 children by pediatrician $\mathrm{A}$ in order to measure the stability of her judgment.

To make these tests comparable with the annual physical examinations the following precautions were taken: (1) The distribution of the nationality of the 208 children included in the check-up examinations corresponded roughly to the nationality of the 713 boys and girls on whom the indices were tested (table 32 ); (2) the three pediatricians (two women, $A$ and $B$, and one man, $C$ ) who made the examinations were exceptionally well qualified for the task, having had similar training and experience, especially in examining New Haven childrena factor of considerable importance in studying the variability of their clinical judgment; (3) each physician was provided with the set of instructions used by pediatrician $\Lambda$ in completing the annual

a few of these 208 children, 21 boys and 18 girls, were not inelueled in the group on which the indices were tested. 
physical examinations; (4) the importance of following the instructions in arriving at a judgment of general nutritional status was stressed, although the physicians did not work together before beginning the check-up examinations to test their interpretations of the instructions or to compare their methods of assessment; and finally, (5) no time limit was set for completing an examination.

TABLE 32.-Nationality of 107 boys and 101 girls included in the chech-up examinations

\begin{tabular}{|c|c|c|c|c|c|c|}
\hline \multirow{2}{*}{ Nationality I } & \multicolumn{2}{|c|}{ Both sexes } & \multicolumn{2}{|c|}{ Boys } & \multicolumn{2}{|c|}{ Girls } \\
\hline & Nurnber & Pereent & Number & Pereent & Number & P'ercent \\
\hline Total. . & 208 & 100.0 & 107 & 100.0 & 101 & 100.0 \\
\hline $\begin{array}{l}\text { Italian } \\
\text { American } \\
\text { Russian } \\
\text { Polish } \\
\text { Irish } \\
\text { All others }\end{array}$ & $\begin{array}{r}90 \\
44 \\
18 \\
8 \\
13 \\
35\end{array}$ & $\begin{array}{r}43.3 \\
21.2 \\
8.7 \\
3.8 \\
6.2 \\
16.8\end{array}$ & $\begin{array}{r}47 \\
22 \\
9 \\
5 \\
6 \\
18\end{array}$ & $\begin{array}{r}43.9 \\
20.6 \\
8.4 \\
4.7 \\
5.6 \\
16.8\end{array}$ & $\begin{array}{r}13 \\
22 \\
9 \\
3 \\
7 \\
17\end{array}$ & $\begin{array}{r}42.6 \\
21.8 \\
5.9 \\
3.0 \\
6.9 \\
16.8\end{array}$ \\
\hline
\end{tabular}

1 Classification was based on the birthplace of 3 of the child's grandparents. The elassification "Amcri. can" includes not only children 3 of whose grandparents were born in the Uniterl States but also children whose parents and 2 of whose grandparents were born here.

The routine adopted for making the observations was as follows: On the first day of observation the child was examined by pediatrieian A. ${ }^{32}$ On the following day he was to be examined by $\mathrm{B}$, and also by $\mathrm{C}$. Unfortunately, it was administratively impossible to ha re A's reexamination made immediately after the three physical examinations by $\mathrm{A}$, $B$, and $C$. An interval of 13 days elapsed, on the average, before $A$ reexamined the children. Table 33 shows the number and percentage of these ehildren aceording to the interval between A's original and repeat examinations.

TABLE 33.-Interval between the initial and repeat check-up cxaminations of 51 boys and 52 girls made by pediatrician il

\begin{tabular}{|c|c|c|c|c|c|c|}
\hline \multirow{2}{*}{ Interval (in (lays) } & \multicolumn{2}{|c|}{ Both sexes } & \multicolumn{2}{|c|}{ 13oys } & \multicolumn{2}{|c|}{ Girls } \\
\hline & Number & l'ercent & Number & Percent & Number & l'ercent \\
\hline Total ...... & 103 & Jon. 0 & 51 & $10 x) .11$ & 52 & $1(x) .0$ \\
\hline $\begin{array}{r}7 \\
8 \\
9 \\
10 \\
11 \\
12 \\
13 \\
11 \\
15 \\
15 \\
17\end{array}$ & $\begin{array}{r}10 \\
6 \\
0 \\
6 \\
8 \\
16 \\
0 \\
5 \\
36 \\
7 \\
5\end{array}$ & $\begin{array}{r}9.7 \\
5.8 \\
6.0 \\
6.8 \\
7.8 \\
15.5 \\
.0 \\
31.8 \\
1.9 \\
1.9\end{array}$ & $\begin{array}{r}7 \\
3 \\
11 \\
3 \\
2 \\
10 \\
11 \\
4 \\
11 \\
11 \\
5 \\
1\end{array}$ & $\begin{array}{r}13.7 \\
5.9 \\
.0 \\
5.9 \\
3.4 \\
19.0 \\
.11 \\
7.8 \\
31.1 \\
9.8 \\
2.11\end{array}$ & $\begin{array}{r}3 \\
3 \\
0 \\
4 \\
6 \\
6 \\
11 \\
4 \\
4 \\
31 \\
2 \\
4\end{array}$ & $\begin{array}{r}5.5 \\
5 \% \\
710 \\
11.5 \\
11.5 \\
7 \% \\
34.5 \\
3.7 \\
7.7\end{array}$ \\
\hline
\end{tabular}

32 On the same day some of these chilelren were also mensured hy anthropomelrists D and F.. See p. 15. 
It would have been more satisfactory, of course, if the repeat examinations had been made earlier. Only a few of the children, however, were ill during the interval between examinations, none of them seriously enough to produce a clinically recognizable change in their general physical condition.

Although this routine was carefully followed, it was impossible to make all the examinations as planned. Made during school hours, they had to be fitted into the teaching program. Likewise, children who were examined on Friday by physician A could not be examined by $\mathrm{B}$ and $\mathrm{C}$ until Monday. In addition, one of the pediatricians, $\mathrm{C}$, became ill and was unable to examine 52 boys and 53 girls until $A$ made her reexaminations. The resulting maximum interval of time between A's first examination and the examination made by one of the other two physicians is given in table 34 .

TABLE 34.-Maximum interval between initial check-up examination of 107 boys and 101 girls by pediatrician $A$ and examination by pediatrician $B$ or $C$

\begin{tabular}{|c|c|c|c|c|c|c|}
\hline \multirow{2}{*}{ Interval (in days) } & \multicolumn{2}{|c|}{ Both sexes } & \multicolumn{2}{|c|}{ Boys } & \multicolumn{2}{|c|}{ Girls } \\
\hline & Number & Percent & Number & Percent & Number & Percent \\
\hline \multirow{21}{*}{$\begin{array}{l}1- \\
2 \\
3 \\
4 \\
5- \\
6- \\
7 \\
8 \\
9 \\
10 \\
11 \\
12 \\
13 \\
14 \\
15\end{array}$} & 208 & 100.0 & 107 & 100.0 & 101 & 100.0 \\
\hline & 79 & 38.0 & 44 & 41.1 & & 34.5 \\
\hline & 0 & .0 & 0 & .0 & $\begin{array}{r}0 \\
13\end{array}$ & $10^{.0}$ \\
\hline & $\begin{array}{r}27 \\
0\end{array}$ & $\begin{array}{l}11.0 \\
.0\end{array}$ & $\begin{array}{l}11 \\
0\end{array}$ & $\begin{array}{l}10.0 \\
.0\end{array}$ & $\begin{array}{r}130 \\
0\end{array}$ & $\begin{array}{r}12.9 \\
.0\end{array}$ \\
\hline & 0 & .0 & 0 & .0 & 0 & .0 \\
\hline & $\begin{array}{r}0 \\
11\end{array}$ & $\stackrel{5}{5}^{0}$ & $\begin{array}{l}0 \\
8\end{array}$ & $\therefore 0$ & 0 & .0 \\
\hline & $\begin{array}{r}11 \\
6\end{array}$ & 2.9 & $\begin{array}{l}8 \\
3\end{array}$ & $\begin{array}{l}.0 \\
2.8\end{array}$ & $\begin{array}{l}3 \\
3 \\
3\end{array}$ & $\begin{array}{l}\text { 3.0 } \\
3.0\end{array}$ \\
\hline & 0 & .0 & 0 & $\therefore 0$ & 0 & .0 \\
\hline & 7 & 3.4 & 3 & 2.8 & 4 & 4.0 \\
\hline & 8 & 3.8 & 2 & 1.9 & 6 & 5.9 \\
\hline & 16 & 7.7 & 10 & 9.3 & 6 & 5.9 \\
\hline & 0 & .0 & 0 & .0 & 0 & \\
\hline & 8 & 3.8 & 4 & 3. 7 & 4 & 4.0 \\
\hline & 36 & 17.3 & 16 & 15.0 & 20 & 19. $\mathrm{s}$ \\
\hline & 7 & 3.4 & 5 & 4.7 & 2 & 2.0 \\
\hline & 5 & 2.4 & 1 & .9 & 4 & 4.0 \\
\hline & 0 & .0 & 0 & .0 & 0 & .0 \\
\hline & 0 & 0 & 0 & .0 & 0 & \\
\hline & 0 & .0 & 0 & .0 & 0 & .0 \\
\hline & 0 & .0 & 0 & .0 & 0 & .0 \\
\hline & 1 & .5 & 0 & .0 & 1 & 1.0 \\
\hline
\end{tabular}

From this table it may be seen that, on the average, a period of 7 days elapsed between the physical examinations of $A$ and $B$, or $A$ and $\mathrm{C}$, although about 50 percent of the children were examined within 3 days and 38 percent during a 1-day period.

\section{REVIEW OF THE LITERATURE}

Before turning to a discussion of the variability of these findings, it may be well to review rather briefly some of the studies bearing on this point which have appeared recently in the literature of the subject.

One study is deseribed in an article by Mayhew Derryberry (25) entitled "Reliability of Medical Judgments on Malnutrition," pub- 
lished in Public Health Reports (U. S. Public Health Service) for February 18, 1938. The article may be summarized, in part, as follows:

Six experienced pediatricians examined, independently, 10811 -year-old boys who represented the entire 11 -year-old population-both resident and nonresidentof an institution in New York City. There was no time limit for making these examinations; the boys were usually stripped to the waist, and their nutrition was graded aecording to the Dunfermline seale ${ }^{33}$ as "excellent," "good," "fair," or "poor." The physicians who made these examinations differed markedly in the number of children they found to be poorly nourished. The number each physician selected was as follows: $2,6,7,10,12$, and 15 .

"But even more confusing was the fact," writes Derryberry, "that children classed as malnourished by one physieian frequently were not the same children that were rated malnourished by another physician * * * In all there were 25 of the 108 boys rated 'poor' by at least one of the physicians but only 1 who was so rated by the entire group of doctors **** Two of the eases were given every rating in the seale." 34 Derryberry confirmed these findings ${ }^{36}$ by the analysis of a similar series of examinations made by five women physicians on 113 girls ${ }^{36}$ attending an institution in New Jersey.

In summarizing the results of this study Derryberry concludes that whether or not a boy or girl is rated as malnourished depends more on the physician who is the examiner than it does on the actual condition of the child.

Another study, made by R. Huws Jones (51) and reported in the Journal of the Royal Statistical Society, Part I. 1938, is also concerned, among other subjects, with the variability of clinical judgment. Pertinent sections of this report may be summarized as follows:

The observations were made in three localities, Liverpool, Mancliester, and Prescot. In Liverpool 142 white boys ${ }^{37}$ who were attending two sehools in a poor district were examined by four experienced male members of the Medieal Department of the Liverpool Edueation Committee. These physicians were asked to assess nutrition as they would in ordinary routine examinations and to place a child in one of eight nutrition grades: $5,4+$ (excellent) $4,4-$ (normal); $3+, 3$ (subnormal); and 3-,2+ (bad). Although they diseussed the definitions and points of procedure before making the examinations, their judgment varied considerably.

The results of these examinations may be summarized as follows: Although all four physicians agreed on 34 pereent of the children, most of them were normal in nutrition; the number of cases of excellent nutrition ranged from 1 to 17 and of subnormal or bad nutrition from 8 to 23 ; for 12 of the 142 boys there was a difference of three or more grades in the physicians' assessments, and for one child, a difference of five grades. Of 30 boys whose nutrition was graded as subnormal or bad by one or more of the four physicians, only 3 were there by agreement of all four.

\footnotetext{
33 See Appendix II: (25) Derryberry, P. 265.

34 I 1 .

as 'There was more uniformity in the proporion of ehiluten classifiel as pure lhan in the previons expmet. ment, but the lisagrcement in the ratings of diflerent physicians uas even more striking.

so Age unknowri.

37 Age unknown.
} 
The second series of observations were made at Manchester, where four assistant school medical officers-two men and two women-examined 168 boys, ${ }^{38}$ the entire population of the senior boys' department of a Manehester sehool. These physicians elassified nutrition in only one of four grades instead of eight as in Liverpool: A, excellent; B, normal; C, slightly subnormal; D, bad. One of them was unable to place certain boys in any but two grades and classified them as either good or poor. Nevertheless, the Manchester inquiry in general confirms the Liverpool findings.

The third test was made at a school in Prescot, where four male medieal offieers, one from the staff of each of the four local authorities cooperating in the study, examined 155 boys, ${ }^{30}$ using the Board of Edueation's classification of four nutritional grades. It is interesting to note that although these physieians came from four areas, they agreed somewhat better than the physicians in Liverpool and Manchester.

This same English study contains also an evaluation of the consistency or stability of clinical judgment. This part of Jones' report may be summarized as follows:

Five of the members of the sehool medical staff of the Cheshire County Couneiltwo men and three women-examined twice each of 193 boys attending two schools in Norwich, one in a good district and the other in a poor district. There was an interval of a week between the first and repeat examinations made by each physieian.

Some of the results of this study are pertinent to the present discussion. In the second examination every one of these physicians found a greater percentage of boys in exeellent nutritional condition, and four out of five found a smaller percentage whose nutrition was subnormal. This difference may be due to the fact that at the initial examinations the children attending the school in the good district were examined first, but when the repeat examinations were made the procedure was reversed.

In other words, it is possible that after examining the boys from the poor district the physieians were all the more impressed by the eondition of the children in the other school. Thus, the seeond physician, when he reexamined the same children, decreased by about one-half the number of boys whose nutrition he judged to be subnormal.

The analyses of these data also show that one of the five physicians changed his assessment in 20 pereent of the cases, and the other four, in 27 to 31 percent. This means that, on the average, they placed one boy in four in a different grade at the second examination. One of the physicians even changed a "slightly subnormal" diagnosis into a diagnosis of "exeellent" and another an "exeellent" into a diagnosis of "slightly subnormal." Further analysis shows that for children found to be malnourished by one or more physicians, eonsisteney of judgment varied from 8 pereent for the first physician to 70 percent for the fourth.

These findings were verified by the results of a seeond experiment undertaken at Bolton, where two local school medical officers and three others (three women and two men physieians) from I Jeigh, Southport, and Wigan conducted the exaninations of 200 boys ${ }^{t 0}$ under eonditions which were similar to those at Norwieh, with the exception of the faet that the differences between the boys from the good and the poor rlistricts were not so great.

The results of this study confirm in general the investigation made at Norwieh, although the consisteney of elinical judguent at Bolton was greater, owing in part

39 Age. ruen, and suciueconomic status unknown.

30 $\mathrm{Age}$, race, and sociucconomic status unknown.

to $\Lambda$ ge unknown. 
to the fact that a larger percentage of the boys in Bolton were normal in nutrition. Thus, three of the physicians were consistent in 50 percent of the eases of subnormal nutrition, the others in 70 and 76 percent, but one physician changed a child two grades-from "bad" to "normal."

In this article Jones summarizes his findings on the subject of clinical judgment, in these words:

Perhaps the most important part of the work reported in this paper is that concerned with the reliability of clinical assessments. It has been shown that the distribution of nutrition found in a given population, and the number and identity of the boys assessed subnormal, are largely dependent upon the particular doctor who makes the assessments. The doctors compared in this inquiry were, with one exception, persons of long experience, and all were urged to take as much time as they wanted over the assessment of each boy. Nevertheless, these doctors show important disagreements not only with each other but also with their own assessments of the same population after a short time interval. The present critieism is directed against the method, not against the doctors concerned; in fact, the care these doctors would take, knowing the purpose of the inquiry, leads one to fear that the results set out in the previous pages may show the position in an unduly favorable light.

As a result of this inquiry, one may venture to claim that the method of assessing nutrition at present followed by school medical officers, on the dircetion of the Board of Education, is unreliable. The results obtained by that method are, to say the least, of doubtful value.4l

\section{Investigations by Betenson (8) and Herd (46) confirm these find-} ings. Betenson writes:

The experiment of nine which he [Harris ${ }^{42}$ ] was good enough to mention was, I think, the first of this nature te demonstrate what faulty conclusions can be arrived at by various doctors using a classifieation which had no scientific basis at all. I expect you know that onr Board of Education in London about 3 rears ago wished us to classify all our school children into four categories called (A) excellent, (B) normal, (C) slightly subnormal, and (D) bad, and it was on purpose to find out how a definite area in South Wales was responding to this classification that I suggested that three medical men, one from each county, and the same of medical women should meet together in one of my schools. The meeting accordingly took place, the children were selected unknown to any of us by a school nurse, and these children passed in turn before all six of us, who were spaced quite a considerable distance apart from one another in a fairly large room, the object being that we should not have any discussion at all on any of the children or see one another's classifications until all the 100 harl been seen.

When these examinations were completed, the average agreement between any pair of observers was found to be as low as two out of five. ${ }^{43}$

The other investigation reported by Herd $\left(46^{\circ}\right)$ showed clinieal assessment by medieal oflicers to be "absolutely fallacious." 'Thus, in one test in which 36 children were graded as excellent, only 3 were

"See Appendix IJ: (\$1) Jone's, p. 33.

42 See Appondix II: (44) Ilarris, p. 226.

13 See Appendix II: (44) Ilurris, p. 220. 
agreed upon by all the medical officers, and the variability was even greater in the normal and slightly subnormal nutritional groups. ${ }^{44}$

Each of these studies has certain limitations. For example, the interval between the physical examinations was too long in the Cheshire County experiment; Derryberry did not indicate the length of time which intervened between the examinations made in New York City; and different numbers of nutritional grades were used in Liverpool and in Manchester, so that the findings for these two cities are not directly comparable. Similarly, no information is available concerning the socioeconomic status of the children examined in the study reported by Herd. Even more important is the fact that in some instances, so far as is known, there were no detailed instructions for making the physical examinations; this seems to be the case in Jones' investigations. Nevertheless, in spite of these shortcomings, the studies all indicated that clinical judgment is liable to considerable error and that as a result it is not always a satisfactory criterion of physical fitness.

Do the check-up examinations made on some of the boys and girls included in this study confirm these findings?

\section{VARIABILITY OF CLINICAL JUDGMENT IN THE PRESENT S'TUDY}

In answering the question asked in the preceding section it should be borne in mind that pediatrician $\mathrm{A}$ made all the annual physical examinations during both years of the study. Consequently, it is important to know how her clinical judgment of nutrition compares with the judgment of the other pediatricians, $\mathrm{B}$ and $\mathrm{C}$. This problem is, of course, somewhat different from the one in which Jones, Derryberry, Herd, and others were interested, because they were concerned with the variability and reliability of clinical judgment as such, rather than with the accuracy of one pediatrician's judgment.

It will be remembered in this connection that $\mathrm{A} ; \mathrm{B}$, and $\mathrm{C}$ each examined 208 7-year-old children-107 boys and 101 girls-and that they graded nutrition as excellent, good, borderline, poor, or very poor (See p. 36).

Table 35 shows the results of these examinations. In evaluating this table it is well to keep in mind the fact that if clinical judgment is to be used as a criterion of physical fitness for identifying children in need of medical attention or nutritional assistance, it is especially important to consider the number of boys and girls each physician juclged to be in poor or very poor nutritional conditon. This table indicates that the pediatricians disagreed concerning the number of

14 This statement is contained in a diseussion of a paper by Woolham. Seo Appendix 11: (126) Woolham, p. 260. 
children, especially boys, whom they placed in these two nutrition grades. A selected $8 ; \mathrm{B}, 41 ; \mathrm{C}, 22$ of the 107 hoys as poolly or very poorly nourished. (Corresponding figures for the girls are 1. 13; $\mathrm{B}, 22$; and $\mathrm{C}, 18$.) ${ }^{45}$

TABLE 35.- Nutritional status of $10 \%$ boys and 101 girls as estimated by pediatricians $A, B$, and $C$ at the check-up exrminations

\begin{tabular}{|c|c|c|c|c|c|c|c|c|c|c|c|c|}
\hline \multirow{4}{*}{ Nutritional status } & \multicolumn{6}{|c|}{ Boys } & \multicolumn{6}{|c|}{ Girls } \\
\hline & \multicolumn{6}{|c|}{ Pediatrician- } & \multicolumn{6}{|c|}{ Pediatrician- } \\
\hline & \multicolumn{2}{|c|}{ A } & \multicolumn{2}{|c|}{ B } & \multicolumn{2}{|c|}{$\mathrm{C}$} & \multicolumn{2}{|c|}{ A } & \multicolumn{2}{|c|}{ B } & \multicolumn{2}{|c|}{$\mathrm{C}$} \\
\hline & $\underset{\text { huer }}{\text { Num- }}$ & $\begin{array}{l}\text { Per- } \\
\text { cent }\end{array}$ & Num- & $\begin{array}{l}\text { Per- } \\
\text { cent }\end{array}$ & $\underset{\text { ber }}{\text { Num- }}$ & $\begin{array}{l}\text { Per- } \\
\text { eent }\end{array}$ & $\begin{array}{c}\text { Num- } \\
\text { ber }\end{array}$ & $\begin{array}{l}\text { Per- } \\
\text { cent }\end{array}$ & $\underset{\text { Num }}{\text { Nuer }}$ & $\begin{array}{l}\text { Per- } \\
\text { rent }\end{array}$ & Num- & $\begin{array}{l}\text { Per- } \\
\text { cent }\end{array}$ \\
\hline Total $\ldots$ & 107 & 100.0 & 107 & 100.0 & 107 & 100.0 & 101 & 100.0 & 16,1 & 100.0 & 101 & $1(n) .0$ \\
\hline $\begin{array}{l}\text { Excellent } \\
\text { Good } \\
\text { Borderline. } \\
\text { Poor } \\
\text { Very poor }\end{array}$ & $\begin{array}{r}2 \\
29 \\
68 \\
8 \\
0\end{array}$ & $\begin{array}{r}\therefore .9 \\
27.1 \\
63.5 \\
7.5 \\
.0\end{array}$ & $\begin{array}{r}3 \\
19 \\
4 \cdot 1 \\
40 \\
1\end{array}$ & $\begin{array}{r}2.8 \\
17.8 \\
41.1 \\
37.4 \\
.9\end{array}$ & $\begin{array}{r}1 \\
13 \\
69 \\
22 \\
0\end{array}$ & $\begin{array}{r}3.7 \\
12.1 \\
63.6 \\
20.6 \\
.0\end{array}$ & $\begin{array}{r}3 \\
31 \\
51 \\
13 \\
0\end{array}$ & $\begin{array}{r}3.0 \\
33.6 \\
51 . .5 \\
12.9 \\
.0\end{array}$ & $\begin{array}{r}4 \\
30 \\
55 \\
20 \\
2\end{array}$ & $\begin{array}{r}1.0 \\
19.8 \\
54.4 \\
19.8 \\
2.0\end{array}$ & $\begin{array}{c}10 \\
14 \\
59 \\
18 \\
0\end{array}$ & $\begin{array}{r}9.9 \\
13.9 \\
59.1 \\
17.8 \\
.0\end{array}$ \\
\hline
\end{tabular}

These findings should be interpreted cautiously, for they do not indicate how frequently the three pediatricians agreed on any one child's nutritional status. For example, it is impossible to determine from the preceding table whether the eight boys selected by 1 were also selected by $B$ or by $C$. Table $36^{46}$ answer's these questions for

4s $\mathrm{A}$ and $\mathrm{C}$ did not seleet any children as very poorly nourished; $\mathrm{B}$ identified 2 girls and 1 boy. On" mas infer from these figures either that the physieians agreel that very few of the childron were very porly nourished or that they were elassifying the children into 4 instead of 5 nutritional grades.

46 This table has been derived from a large number of more detailed tabulations. It may be uswl to derive auditional infornation eoneerning the ebeek-up examinations. For cxample, it is possible to determine the number of boys $\mathrm{A}$ classified as poorly or very poorly nourished whom $\mathrm{B}$ placed in our of the unher nutritional grades, and the number of boys B classified as poorly or very poorly nourisherl whom 1 placed in one of the other grades. It is also possible to aseertain the total number of boys $B$ graded as in Inorterline, gonel. and excellent mutritional eondition, as well as the number $A$ plaeed in these 3 grades. Thus, A clissified 8 boys as poorly or very poorly nourisherl; 5 of these 8 hoys were also judged to be poorly or very poorly nourished by pediatrician 13. In other words, B placed 3 of these 8 boys in one of the other 3 nutritional grades; likewise, the 36 out of 41 boys B graded as poorly or very poorly nourished, A Jlamel in on uf the other nutritional grades. Similarly, if A judgud s boys to be poorly or rery poorly nourished and slie mun ined 107 boys, she must have placed 99 boys in the other nutritional grales, ane] so forth. These fienus form the necessary data for making fourfold tables of the following tym:

Association between the estimates male by peliatricians. 1 and 13 of the nutritional status of 10 i boys at the check-up examinations:

\begin{tabular}{|c|c|c|c|}
\hline \multirow[b]{2}{*}{ Estimates by pediatrieian A } & \multicolumn{3}{|c|}{ Estimales by fmoliutrejan Ii } \\
\hline & $\begin{array}{l}\text { I'one or } \\
\text { bery loor }\end{array}$ & ()hlut & Tot al \\
\hline $\begin{array}{l}\text { l'oor or very poor } \\
\text { Othrer } 1 .\end{array}$ & $\stackrel{5}{a}$ & $\begin{array}{r}3 \\
613\end{array}$ & \\
\hline 'Total .......... & 11 & ini & 107 \\
\hline
\end{tabular}

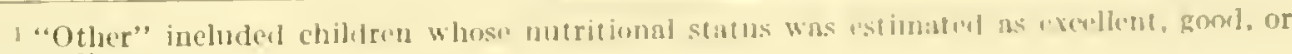
horterline. 
only two grades, poor and very poor nutrition. ${ }^{47}$ For example, it shows that both $\mathrm{A}$ and $\mathrm{B}$ selected 5 boys as poorly or very poorly nourished, although $A$ classified a total of 8 and $B, 41$ boys in this grade; $\mathrm{C}$ selected 22 boys but agreed with $\mathrm{A}$ on only 3 as being in poor or vel'y poor nutritional condition. Similarly, A and B and A and C also identified 9 girls as poorly or very poorly nourished, although $\mathrm{A}$ placed $13, \mathrm{~B}, 22$, and $\mathrm{C}, 18$ in these nutritional classes.

TABLE 36.--Agreement among pediatricians $A, B$, and $C$ in their estimates of poor or very poor nutritional status among the $10 \%$ boys and 101 girls at the chech-up examinations

\begin{tabular}{|c|c|c|c|c|}
\hline \multirow{2}{*}{ Pediatricians } & \multicolumn{2}{|c|}{ Boys } & \multicolumn{2}{|c|}{ Girls } \\
\hline & Number & Percent & Number & Percent \\
\hline $\begin{array}{l}\mathrm{A} \\
\mathrm{C} \\
\mathrm{A} \text { and } \mathrm{B} \\
\mathrm{A} \text { and } \mathrm{C} \\
\mathrm{B} \text { and } \mathrm{C} \text {, } \mathrm{B} \text {, and } \mathrm{C}\end{array}$ & $\begin{array}{r}8 \\
41 \\
22 \\
5 \\
3 \\
18 \\
3\end{array}$ & $\begin{array}{r}7.5 \\
38.3 \\
20.6 \\
4.7 \\
2.8 \\
16.8 \\
2.8\end{array}$ & $\begin{array}{r}13 \\
22 \\
18 \\
9 \\
9 \\
14 \\
8\end{array}$ & $\begin{array}{r}12.9 \\
21.8 \\
17.8 \\
8.9 \\
8.9 \\
13.9 \\
7.9\end{array}$ \\
\hline
\end{tabular}

It is clear from these tables that $A$ was the most conservative and $B$ the least conservative of the three pediatricians, and that variability of clinical judgment appears to be considerably greater for the boys than for the girls.

It is interesting to reexamine this material also in terms of the amount of disagrecment between the nutritional ratings made by two pairs of observers-namely, $\mathrm{A}$ and $\mathrm{B}$, and $\mathrm{A}$ and $\mathrm{C}$-without taking into account either the nutritional grades or the direction of the differences; that is, whether $\mathrm{B}$ or $\mathrm{C}$ graded a child as better or more poorly nourished than A.

According to tables 37 and 38, if the pediatricians disagreed, their judgment usually differed by only one grade. It should be remembered, however, that a difference of one grade may determine whether a child is or is not selected as poorly or very poorly nourished and in need of medical attention or nutritional advice and assistance.

'T'ABIE 37.-Difference between the estimates made by pediatricians $A$ and $B$ of the nutritional status of 107 boys and 101 girls at the check-up examinations

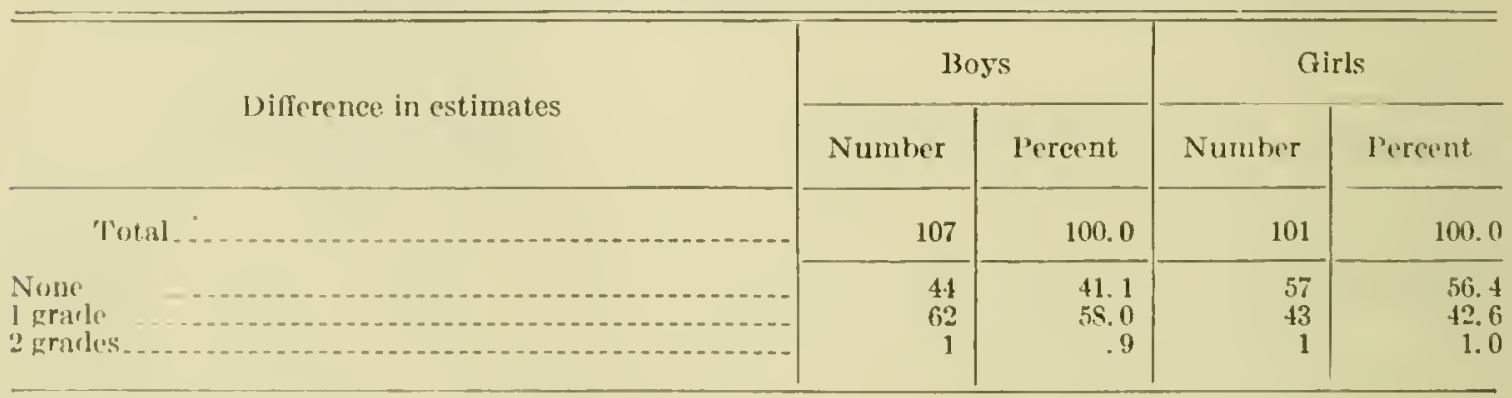

17 See supplementary tablos X1X-XXIV, Appendix I, pl. 112-114: for a more detailed analysis of tho physicians' r'llings. 
TABLE 38.-Difference between the estimates made by pediatricians $A$ and $C$ of the nutritional status of $10 \%$ boys and 101 girls at the chech-up examinations

\begin{tabular}{|c|c|c|c|c|}
\hline \multirow{2}{*}{ Difference in estimates } & \multicolumn{2}{|c|}{ Boys } & \multicolumn{2}{|c|}{ Girls } \\
\hline & Number & Pereent & Number & l'ercent \\
\hline Total... & $10 \tau$ & 100.0 & 101 & 100.0 \\
\hline $\begin{array}{l}\text { None } \\
\text { I grade } \\
2 \text { grades }\end{array}$ & $\begin{array}{r}63 \\
44 \\
0\end{array}$ & $\begin{array}{r}58.9 \\
41.1 \\
.0\end{array}$ & $\begin{array}{r}64 \\
37 \\
0\end{array}$ & $\begin{array}{r}63.4 \\
36.6 \\
.0\end{array}$ \\
\hline
\end{tabular}

At this point in the discussion it may be well to ask, in summary, how frequently these three physicians agreed concerning a child's nutritional status. Table 39 shows that they agreed on 31 of the 107 boys and 46 of the 101 girls, but 22 of these 31 boys and 32 of the 46 girls were in borderline nutrition. To express these findings somewhat differently: The agreement between the three pediatricians was least satisfactory for children who deviated markedly from the average; namely, those who were judged to be good or excellent in nutrition and those whose nutritional status was poor or very poor. All this evidence confirms the findings of Jones, Derryberry, Betenson, and others ${ }^{48}$ that elinical judgment of nutrition is subject to considerable variation and is not always consistent.

TABLE 39.-Extent of agreement among pediatricians A, B, and $C$ in their estimates of nutritional status of the boys and girls at the check-up examinations ${ }^{1}$

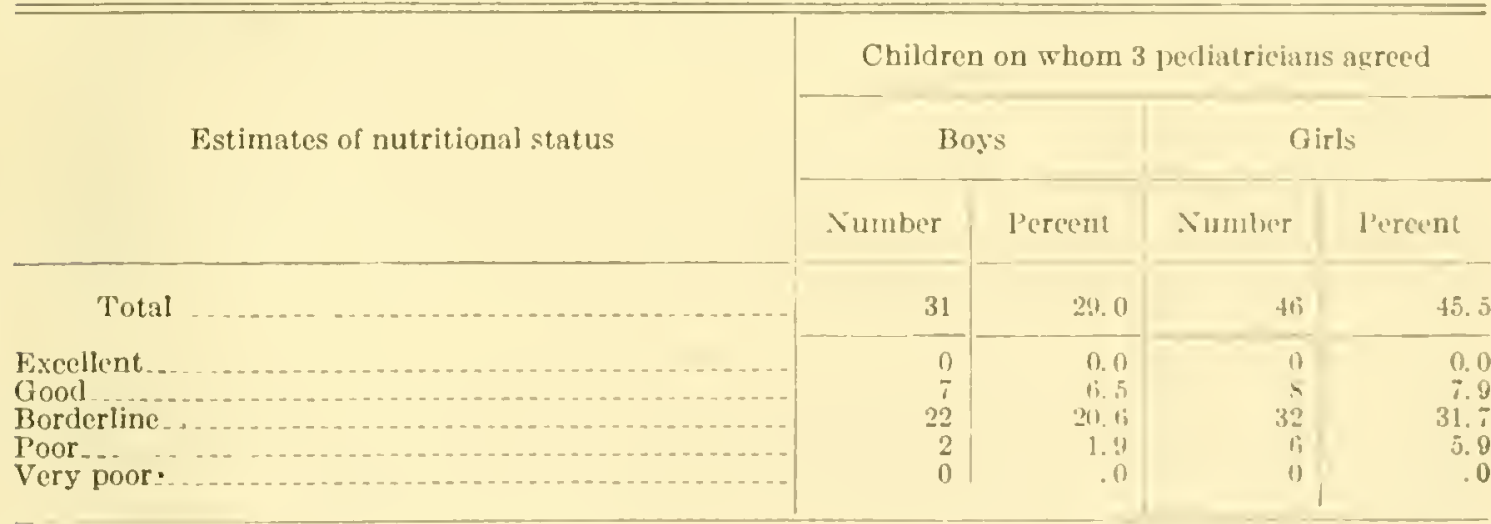

1 The 3 pediatricians agreed on the ratings of 31 of the 107 boys and 46 of the 101 girls inclucler in the checkup examinations.

\section{STABILITY OF CIINICAI, JUDGMENT IN THE PRESENT STUDY}

Although $\mathrm{A}$ often disagreed with $\mathrm{B}$ or $\mathrm{C}$, her own judgment was relatively stable. The findings at her first and repeat physieal examinations of 103 children, 51 boys and 52 girls, are shown in table 40. This table indicates that at each examination $A$ classified about the same number of boys in good and borderline nutritional condition, but did not identify the same number as likely to be poorly nourished.

45e Avvendix 1I: (91) Koberts. Stone, and Bowler. Sce also references ziven on 1p. soll. 
The table also shows that $A$ 's judgment was probably less consistent for girls than for boys. ${ }^{49}$

TABLE 40.-Estimates made by pediatrician A of the nutritional status of 51 boys and 52 girls at the initial and repeat check-up examinations

\begin{tabular}{|c|c|c|c|c|c|c|c|c|}
\hline \multirow{3}{*}{ Nutritional status } & \multicolumn{4}{|c|}{ Boys } & \multicolumn{4}{|c|}{ Girls } \\
\hline & \multicolumn{2}{|c|}{ Initial examination } & \multicolumn{2}{|c|}{ Repeat examination } & \multicolumn{2}{|c|}{ Initial examination } & \multicolumn{2}{|c|}{ Repeat examination } \\
\hline & Number & Percent & Number & Percent & Number & Percent & Number & Pereent \\
\hline Total & 51 & 100.0 & 51 & 100.0 & 52 & 100.0 & 52 & 100.0 \\
\hline $\begin{array}{l}\text { Excellent } \\
\text { Good } \\
\text { Borderline } \\
\text { Poor } \\
\text { Very poor }\end{array}$ & $\begin{array}{r}0 \\
13 \\
34 \\
4 \\
0\end{array}$ & $\begin{array}{r}0.0 \\
25.5 \\
66.7 \\
7.8 \\
.0\end{array}$ & $\begin{array}{r}0 \\
14 \\
35 \\
2 \\
0\end{array}$ & $\begin{array}{r}0.0 \\
27.5 \\
68.6 \\
3.9 \\
.0\end{array}$ & $\begin{array}{r}2 \\
16 \\
28 \\
6 \\
0\end{array}$ & $\begin{array}{r}3.8 \\
30.8 \\
53.9 \\
11.5 \\
.0\end{array}$ & $\begin{array}{r}2 \\
14 \\
34 \\
2 \\
0\end{array}$ & $\begin{array}{r}3.8 \\
26.9 \\
65.5 \\
3.8 \\
.0\end{array}$ \\
\hline
\end{tabular}

The association between the nutritional ratings made of each child at the examinations designed to check the stability of the pediatrician's judgment is shown in tables 41 and 42 . These tables indicate that A's judgment was most stable for boys and girls in a borderline nutritional condition and least stable for those who were likely to be poorly nourished.

If these tables are examined in terms of the number of boys or girls who were placed in the same nutritional grade at both initial and repeat physical examinations, expressed as a percentage of the number who were placed in this grade at the initial examination, it may be seen that at the repeat examination $\mathrm{A}$ gave a borderline nutritional rating to about 88 percent of the boys whom she placed in this same grade at the initial examination; a good rating to about 77 pereent and a poor nutritional rating to only 50 pereent of the boys classified in this grade at the initial examination. Corresponding figures for the girls were about 89 percent, 69 percent, and 33 percent, respectively. In other words, there is considerable evidence that A's judgment was least stable for the children whom it was most important to identify; namely, those who were likely to be in poor nutritional condition.

TABLE 41.-Association between the estimates made by pediatrician $A$ of the nutritional status of 51 boys at the initial and repeat check-up examinations

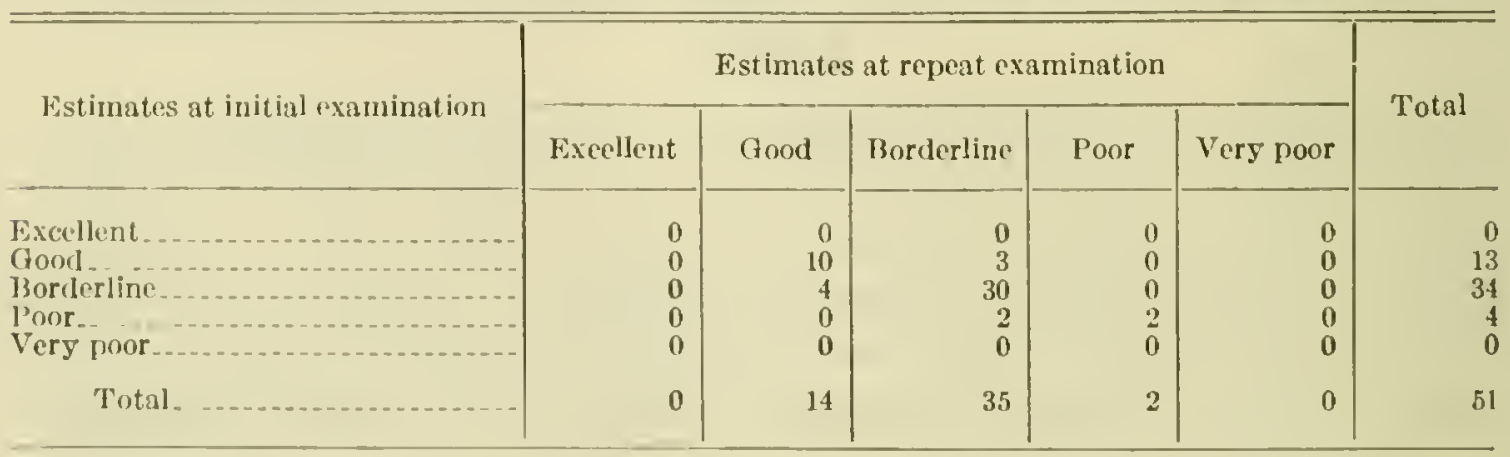

10 The number of boys and girls classified as poorly nourished is small and the results must be interpreted cautiously. 
TABLE 42.-Association hetween the estimates made by pediatrician $A$ of the nutritional status of 52 girls at the initial and repeat check-up examinations

\begin{tabular}{|c|c|c|c|c|c|c|}
\hline \multirow{2}{*}{ Fstimates at initial examination } & \multicolumn{5}{|c|}{ Estimates at repeat examination } & \multirow{2}{*}{ Total } \\
\hline & Excellent & Good & Borderline & Poor & Very pror & \\
\hline $\begin{array}{l}\text { Exeellent } \\
\text { Good } \\
\text { Brorderline } \\
\text { Poor } \\
\text { Very poor }\end{array}$ & $\begin{array}{l}2 \\
0 \\
0 \\
0 \\
0 \\
0\end{array}$ & $\begin{array}{r}0 \\
11 \\
3 \\
0 \\
0\end{array}$ & $\begin{array}{r}0 \\
5 \\
25 \\
4 \\
0\end{array}$ & $\begin{array}{l}0 \\
0 \\
0 \\
2 \\
0\end{array}$ & $\begin{array}{l}0 \\
0 \\
0 \\
0 \\
0\end{array}$ & $\begin{array}{r}2 \\
1 n \\
29 \\
0 \\
0\end{array}$ \\
\hline Total . & 2 & 14 & 34 & 2 & 0 & 52 \\
\hline
\end{tabular}

In interpreting these findings it is well to bear in mind that the pediatrician who made all the examinations in this study was cxceptionally well-trained and had had considerable experience in examining school children, particularly boys and girls living in New Haren. Certainly her clinical judgment is as satisfactory as that of many other physicians. It is also well to point out that even if her judgment was not always consistent and objective, it is probably a more satisfactory criterion than the individual judgments of several physicians would have been. A real advantage exists, therefore, in having had the clinical data for this study collected by one observer.

Nevertheless, the evidence indicates that A's judgment was liable to considerable error and should be followed with reservations as a criterion for evaluating indices of physical fitness or nutrition.

\section{OPINIONS AND RECOMIENDATIONS OF OTHERS}

To sum up this discussion of clinical judgment, it is illuminating to survey the opinions and recommendations of other investigators.

Various writers have pointed ont the necessity for improving the clinical examination. Lishman states it this way:

We have tended in the past to rey too much when making our assessment upon "general impressions," and the more striking skeletal defects arising from insuffieient food, as distinet from imperfect functioning of the many processes involved in nutrition, to the exchusion of specifie signs of probable nutritional deficieney revealed after questioning the parent or teacher and examining the child. ${ }^{50}$

Brewer is more specific in his criticism. He points out that the average physician has been taught in medical school to diagnose pathological conditions and has had limited experience in examining healthy children. Brewer continues: "**** though we have hundreds of specialists in children's diseases, we have few in children's health and theso few are not comnted as specialists unless they approach their function through pathology." 51 
The White House Conference of 1930 has pointed out the necessity for making seriatim examinations and appraising the individual child in terms of the progress made between examinations. Improvement in his condition, the Conference reported, is often of far greater significance than status at the moment. ${ }^{52}$

The Lancet takes a less conservative attitude in an editorial on the variability of clinical judgment of nutrition. This editorial interprets the problem as an "indietment of a system, not of the medical assessor, of whom the impossible, it seems, is being asked." 53

Stuart, in a more detailed discussion, writes:

The clinician is constantly comparing one child with a composite picture of children of similar age. This picture includes a wide range of variations which he has come to expect on the basis of experience. The way any one physician will interpret a child will depend both upon the accuracy of his observations and upon the extent and type of his personal experience..$^{54}$

Eliot illustrates this aspect of the diseussion in writing of the physical examinations made of Puerto Rican children by physicians accustomed to judging the nutritional status of New Haven, Conn., school children:

That the usual standard of gauging the physical condition of the children was not adhered to (because of the preponderance of poorly nourished children), but that a standard based on the range within the group itself was unintentionally substituted, will be shomn later. ***

It was without question the intention of the physicians who made the examinations in Puerto Rico to use the same standards for estimating subcutaneous fat as they had used in similar studies in New Haven, and so to have comparable data from the two places. However, in the face of the preponderance of poorly nourished children and the scarcity of really well-nourished ones, the judgment of the physicians with regard to estimating amounts of subcutaneous fat rapidly became warped, and unintentionally there occurred, in conformity with the variations within the group, a definite readjustment in their whole scale of values, as has been pointed out. Children who in New Haven would have been considered to have a "fair" amount of subcutaneous fat, were, because of this unconscious readjustment of standards, reported as having a "good" amount, and those who in New Haven would have been considered to have a "poor" amount were reported as having a "fair" amount. There is little doubt that the ratings of the fat of these Puerto Rican children are high as compared with the ratings given in New Haven by the sante physicians. 55

In discussing the situation in Fngland, Herd expressed the same point of vicw:

All children inspected in the routine age groujs are assessed by the medical oflicers in regard to their state of mutrition * * *. 'This assessment is an attempt to gauge the general physical eondition of the child, as apart from specific

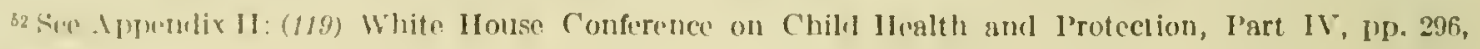
3010301.

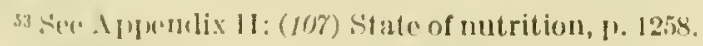

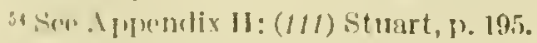

"sine Afinntix 11: (115) U.S. Childron's 13urenu, l"ublication No. 217, p. 25. Sec also Grecn (4\$) for discussion of this same subject.
} 
defects. Some defects would count little or not at all in such an assessment, e. g., defeets of the senses; on the other hand, the presence of a generalized defect like anemia would naturally place a child in a low grade nutritionally. Assessment is made partly by static qualities-stature, bulk, skin, color, muscle tone, ete.partly by dynamic qualities-alertness, general liveliness, and activity. These qualities are not measurable, except stature and bulk, and it is even questionable whether such measurable quantities should be given much weight in the decision, especially stature, which is so eminently a hereditary quality. Assessment therefore has to be decided by individual judgment, based upon past experience. There is room therefore for considerable difference in the assessments made by individual medical officers and of this a good deal of evidence has been found.56

\section{In other words, according to Catheart:}

There is no reliable objective measure of the state of mutrition. The physical measurements of the child do not give much help and the other generally accepted signs are in the main subjective, the gloss of the hair, the bloom of the skin, the brightness of the eye, the alertness of response, and so on. Each doctor forms his own mental standard and judges the ehildren by this subjective measure. All subjective measures are liable to great distortion. They seen, no doubt, to the individual to be fixed and sure, but are indeed fluid. His judgment is warped by his immediately preceding stimulus. If he has examined a group of children who are fit and well and the next group is less satisfactory, he ranks the sccond group lower than he would have done had the first group been only very moderate. Intil some objective standard can be devised it is quite impossible to expect any uniformity in assessment of nutrition in a wide area. Too oftell, as Bacon has said, the eye of the examiner "is bedewed with human passion." si

An interesting discussion of this aspect of the problem is also contained in a book entitled "National Fitness," erlited by $F$. Le Gros Clark. In this report the author discusses the clinical sicnificance of the term "normal mutrition" in these words:

We arranged for a letter to be sent to a number of school medical oflicers, asking them to explain to us how they and their assistants interpreted the term "normal" in their reports. Did the term imply that the children so classified reached a fair average standard for the district eonsidered, or did it imply in their minds that the children approximated to a certain ideal standard? ***

Fourteen of the oflicers $* * *$ seemed $* * *$ to mean by normal no nore than a fair average for their area. One flom a nidland borough says: "Normal nutrition implies a fair aversge for the ehild population of the elementary schools of the area; it does not imply that the child so elassified reaches any ideal standard of fitness." His colleague in a northern borough says much the sanne: "My" own impression is that, in the absence of any acepted stanclard for the assessment of nutritional conditions, one is bound to be infuenced by the general average standards of the children examined." A third from a southern borough grives his opinion that "the word normal as used in the service clearly means average or that usually seen." But even those who suggest that nomal muans to them the approximation to some ideal, frequently qualify their stafoments. "Thus a doceter from a southern county renuaks: "Normal nutrition * * * inplie's that the medical oflicer reviewing the child is satisfied that the ehild's condition is sallisfactory in regard to nourishment, taking all the factors into consicleration."

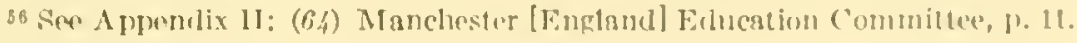

si Sec Appendix 11: (1\%) Catheart, 1. 1s. 
"Normal," says a northern borough officer, "is interpreted as apparently satisfaetory, $i$. e., not showing any apparent evidence of malnutrition."

Actually, out of the 24 replies which were unambiguous, 4 seemed to define normal as in some respect "corresponding to an ideal in the mind of the officer examining." The remainder of the replies either qualify their statements or imply that the normal is at best the average for the child population of today, which is scarcely a high average; it has been described by many as a debased average.

We invite the reader's attention to further quotations from these same letters, if he would ponder the absolute confusion under which the whole problem is submerged. "I disapprove of the whole system of notation, partieularly in its use of the word 'exeellent.' The idea of supernormal nutrition repels me, for I don't believe it can exist" (northern borough). "The whole question of malnutrition depends upon the medieal examiner" (northern borough). "I am inelined to think that the quality [i.e., of the term nutrition] is so indefinite as to make it impossible to obtain a precise standard in any way applicable" (southern county). "I don't know what normal as applied to nutrition means. I wish I did" (northern borough).

[The author continues] *** if the whole idea of this "nutrition assessment" ereates such diseomfort among its many officers, why on earth has the board insisted with sueh regularity on wasting their time in a valueless survey? ${ }^{58}$

\section{Roberts emphasizes another aspect of the problem. She writes:}

The physician's rating is the only one that attempts to recognize qualitative as well as quantitative aspeets, and this is too subjective a method to be of value in situations where sueh rating seales are most desired. ${ }^{50}$

\section{Wilkins is even more forceful in his criticism:}

We may well ask whether anyone is justified in professing to be able to assess such a multiple funetional complex during a few minutes' inspeetion of a child. In my opinion it amounts to little more than guesswork. *** I contend that $* * *$ the anatomieal standards of the art student are an infinitely truer guide to nutritional normality than those of praetitioners and medieal officers who rely on the presence or absence of the usually accepted pathological signs. ${ }^{60}$

The periodical, The Medical Officer, in a recent editorial, raises the same question.

There is every justification for the author's [R. Huws Jones] ${ }^{61}$ finding that "the method of assessing nutrition at present followed by sehool medical officers is unreliable. * * * " He leaves his readers with a fundamental question. Is the state of nutrition an entity eapable of valid measurement? Many of us will answer this question with an emphatie "No." He does not believe that our inspectors are wanting in skill but he does believe that knowledge has not yet advaneed far enough to provide us with a reliable rardstick which will give reasonably consistent results when aceurately applied. ${ }^{2}$

\footnotetext{
39 See Appendix II: (20) Clack, p. 127-134.

59 Soe Appendix [1: (89) Roberts, p. 71.

60 See Appendix 11: (121) Wilkins, 11). 145, 147.

01 See Aplendix II: (5I) Jones.

62 See A ppendix II: (7/) Nutrition of sehool chiluren, I. fit.
} 


\section{Dunstan expresses the same opinion when he writes:}

These returns, being based on qualitative estimates, can never be more than measures of the variability of the personal equation..$^{3} * * *$ It is clear that some mensurational yardstick will need to be devised which will record and classify the physical status of the ehildren by quantitative means. ${ }^{\text {b }}$

In summary, a passage from the report of the Chief Medical Officer of the Ministry of Health of Great Britain gives weight to the findings of this study of New Haven children. The Chief Medical Officer writes:

The assessment of the state of nutrition hy elinical examination is beset with many diffieulties because this method of evaluation involves reliance not on objective data but on subjeetive impressions and on the personal eompetence of the investigator. The standards of the examiner, as well as the results which he obtains, are mental concepts and therefore incapable of precise objective measurement. While different physicians will probably be in general agreement concerning ehildren who are either very healthy or grossly malnourished, slight differences, are likely to oceur with ehildren less elearly differentiated. The decision given will depend on the skill, experience, and judgment of the physieian. If his coneeptual standards remain reasonably constant consistent results will be obtained. But the eonstaney of the criteria of different elinicians is variable. They are liable to vary with the opinion of the physician, with the influence of his surroundings, and with his most recent elinical experience. ${ }^{63}$

The practical importance of this whole topic is outlined by the Committee Against Malnutrition:

In diseussing the nutrition and health of school children, we have first to ask hy what standard they are being judged. What is the optimum physique and health of a nomal ehild? It is clear that, until we know this, we are comparing our children with a standard that may be "debased;" i. e., well below the optimum.

Meanwhile, it has been pointed out (1) that the conception of "malnutrition" as laid down for the sehool medical service is rery unsatisfactory to the scientific mind; (2) that, however stremously the officers may work, the school medical examinations are not adequate for assessing how far the children are actually undernourished; and (3) that there is grave eause for suspecting that the figures returned in different areas for "malnutrition" depend greatly on the subjective and personal impressions of the officers and have very little objective and scientific validity. *** $*$ If our findings are correct, then it is clear that oflicial figures, whatever else they may reveal, do not supply an answer to the vital questionhow far are the children of this conntry underfed and malnourished? bi

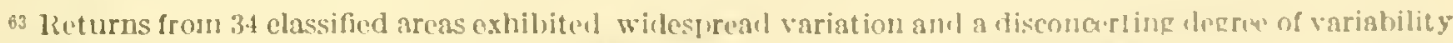
in assessment of nutrition. See reference to Memoramlum of Commitum I gainst Malmutrition, (ret. 1936. contained in Appondix II: (29) Dunstan, 1). 55.

04 Sec $\Lambda$ ppendix 1I: (99) Dunstan, D. 55.

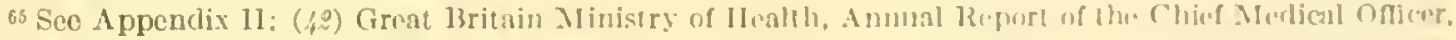
ก). 16-I-165.

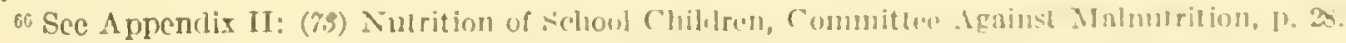




\section{THE NEED FOR IMPROVING CLINICAL JUDGMENT}

If, as the preceding discussion indicates, the clinical examination as it is usually made does not satisfactorily assess the child's physical fitness, how can it be improved? ${ }^{67}$ How can the examination be made more objective and stable? Can its value be increased without the addition of a number of expensive or elaborate laboratory procedures? What items in the physical examination are most accurate? Which ones are most likely to influence the pediatrician's judgment?

In order to answer these and related questions, analyses were made not only of the variability and stability of clinical judgment of general nutritional status but also of the specific clinical items which went to make up the physical examination. The interrelationships between these items have also been studied, as well as their correlation with the physician's judgment of the child's nutritional status. A subsequent report will incorporate findings on these points and will attempt to point out which clinical findings are most reliable and which ones are most likely to influence the pediatrician's judgment of the child's fitness. Does the physician agree with other physicians concerning such findings as the condition of a child's tonsils, his musculature, his subcutaneous tissue, the condition of his mouth and skin? Are his own findings stable? What value or weight does he give each one of these items in arriving at a final judgment of the child's fitness? Is he influenced by the child's size, by the color of his skin, by his posture, or by the child's attitude or his mental alertness?

A study of such questions as these may prove of value in indicating some of the problems of assessing physical fitness. As has been pointed out editorially in the Lancet (see p. 88), it is not the clinician who is at fault but the method which he is asked to use and the conditions under which he must work.

Is it not possible to develop more objective standards? For example, what is meant by enlarged tonsils? What is a satisfactory amount of subcutaneous tissue for a 7-year-old ehild? Do boys of this age have less subcutaneous fat than girls? Such questions as these must be answered either by establishing new norms or by deriving and employing better techniques, if the clinical examination is to be improved and the child's fitness is to be more satisfactorily assessed.

${ }^{67}$ Recent attompts to improve the clinical examination include such studies as those of lishman in Fingland and Glazire in 13oston. See Appendix 11: (57) lishman and (37) Glazier. Fiforts are also being mate to (muploy more specific and claborate tests and thus make the clinical examination morc cletailed as well as noro objective. See A plendix 11: (10) Boone and Ciocco, (5\%a) Kruse, palmer, Schmidt, and Wiehl. ant (102) Schmiclt. 
On the other hand, even if such tools-new norms and better techniques-are available, they may be exacting and expensive to apply, requiring, as they do, elaborate, costly equipment. In addition, the expense involved in making satisfactory periodic examinations of al large group of boys and girls is prohibitive for most communities at the present time. For these reasons indices of body build and other preliminary screens have been developed.

The four screening methods tested in this monograph have not proved efficient. Some other procedures must be found. 


\section{Summary}

Two methods of evaluating physical fitness: (1) Indices of body build, as exemplified by the Baldwin-Wood Weight-Height-Age Tables, the ACH Index of Nutritional Status, the Nutritional Status Indices, and the Pryor Width-Weight Tables; and (2) clinical judgment of general nutritional status have been tested in order to determine both their sensitivity and their selectivity.

The observations were made of 713 7-year-old children (365 boys and 348 girls) who were attending the public or parochial schools of New Haven, Conn., from September 1934 through May 1936. The boys and girls were first examined when they were 6 years of age. The observations included a physical examination made by one welltrained pediatrician, anthropometric measurements taken by one anthropometrist, and socioeconomic data obtained at home visits made by economic analysts. A second set of examinations were made a year later by the same pediatrician and anthropometrist, and by another group of economic analysts. In addition, the boys and girls were weighed at frequent intervals during the course of the study. Toward the end of the observational period, the objectivity and stability of (1) the pediatrician's judgment of general nutritional status and (2) the anthropometric measurements were studied.

The indices have been tested when the child was 7 years of age by comparison with five criteria, which involve clinical judgment of general nutritional status, need of medical and dental care, and an estimate of the child's gain in weight and change in arm girth. These criteria have been based on observations made of the children at both 6 and 7 years of age and on periodic weighings made at frequent intervals during a 19- or 20-month period of observation.

The results of the study may be summarized as follows:

1. In terms of any of these five more or less satisfactory criteria of pliysical fitness, none of the four indices of body build (the BaldwinWood Index, the ACH Index, the Nutritional Status Indices, and the Pryor Index) proves an efficient method of identifying children included in this study who, according to the criteria, are likely to be physically unfit. The indices are neither selective nor sensitive, as they fail to identify a considerable number of boys or girls whom a given criterion selects as likely to be in need of medical carre or nutritional advice and assistance, and, in addition, they of ten identify children who were not selected by the eriterion. 
2. The clinical judgment of the pediatrician who made the examinations was liable to considerable error, in terms of both the variability and the stability of her judgment. This evidence confirms other studies and points to the necessity of improring the physical examination, particularly if need for medical care is to remain an objective of child-health programs. The importance of some measure of the child's growth, such as periodic weighings, is emphasized and the fundamental importance of the child's dietary habits is stressed. Any evaluation of physical fitness must include as a minimum these three aspects of the child's well-being-namely, his physical condition as found at elinical examination, his growth and development, and his dietary habits - if a more satisfactory assessment of physical fitness is to be made.

If this result is to be achieved, constant interchange of information and close cooperation of specialized skilis are needed between professional workers who are in a position to contribute to the appraisal of the physical fitness of children.

Orr, director of the Imperial Bureau of Animal Nutrition, Rowett Institute, Aberdeen, emphasized this need in one of the Harben lectures he delivered recently at the institute. He said:

The problems we have been discussing will not be solved until the laboratory worker, the expert clinician, skilled in detecting the earliest deviations from health, and the school medical officer, who has to deal with large numbers of children, the majority of whom are "border-line" cases of malnutrition, cooperate and pool their knowledge and experience. ${ }^{68}$

\footnotetext{
69 See Appendix I1: (76a) Orr, 11. 23.
} 



\section{Appendix I}

\section{Statistical Methods}

\section{PROCEDURE USED IN DETERMINING A CHILD'S STAND- ING OR SCORE FOR THE PRYOR WIDTH-WEIGHT INDEX}

The proeedure used in determining the ehild's standing or seore for the Pryor Width-Weight Index eorresponds approximately to the procedure employed by Franzen in deriving the Nutritional Status Indices seores except that the standard deviation of the multiple-regression equation for weight on height and width of the bi-iliac erests is unknown. It has, therefore, been approximated by determining the differenees between the observed weights and the theoretical or expected weights of all the children of each sex included in this Children's Bureau study, squaring these differences, and dividing by the number of bors or girls. ${ }^{1}$ It would have been preferable to derive this statistieal constant from the differenees between the observed weights and the expected weights of the children from whose measurements the Pryor Index was derived or, better still, from the formula for the standard deriation of the regression surface, had the necessary data been available. Although this procedure necessinily introduces a certain amount of error, it furnishes a method for elassifying the children according to the Pryor Index.2 ${ }^{2}$

In applying this method, it was necessary to ealeulate foul such standarel deviations, since the Pryor Tables define age at the noarest birthday, instead of age at the last birthday as in this study.

The eomputed standard deviations and the number of children on whose measurements they have been based are as follows:

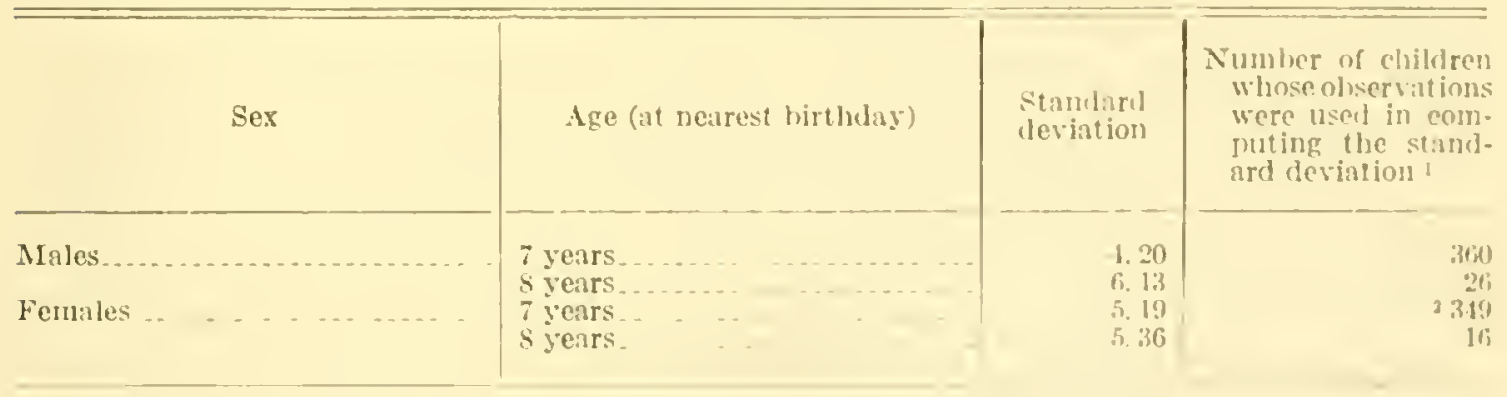

1 Observations of 39 children (21 boys and 18 girls) who were incluklel in 1 he eheek-11p ply wical and anthro. pometric examinations but who were exchudel from the gromp of 713 chiliren on whon the indices were tested, were included in making these est imntes. This fict explains the ditference hetwen the number of children on whom the indices were tested and the mumer whoso measurements were used in calculating the standard deviation.

21 girl whose height excealed the measurentents given in the table was eschdel.

1 The number of degrees of [reedom was taken into account in caleulating the standaru diviations.

2 This procedure hus been approved by 1)r. Pryor in a personal communication, datud Februng 3,1633 . 
These standard deviations were used to derive each ehild's seore: The diflerence between his observed weight and his theoretical weight was divided by the appropriate standard deviation to determine his score, or $x / \sigma$ value, from which his standing or score relative to other children of the same sex, age, and skeletal build (judged in terms of height and width of the iliac erests) may be determined.

For example, the Italian boy, A. R., weighed 46 pounds at 7 years 1 month of age. According to the Pryor Tables, his expected weight was 45.6 pounds. The difference between these two weights is 0.4 pounds. When this number is divided by the appropriate standard deviation, 4.20 pounds, A. R.'s $x / \sigma$ score is 0.1. According to the integral table for the normal-error eurve, 54 boys in 100 of the same age and body build (height and width at the bi-iliac erests) would weigh less than A. R. This method corresponds basically to the one used by Franzen in setting up Table $\mathrm{X}$, shown on p. 65 of the monograph, Nutritional Status Indices. It is based on the assumption that the distribution of the $x / \sigma$ values follows the normal curve of error.

\section{METHOD OF ESTIMATING EACH CHILD'S AVERAGE PER- CENTAGE GAIN IN WEIGHT PER MONTH}

Successive weighings of a child between the ages of 6 and 8 years exhibit a trend which, within the variability of the measurements, is approximately exponential in form. As a result, an estimate of the weight gain of each child included in this study may be made by fitting the exponential equation, $y=a e^{b x}$ to his 8 weighings, made at stated intervals ${ }^{3}$ during a 19 - or 20 -month period of observation, begimning September $1934 .^{*}$

In this equation $y$ is the theoretical (as distinguished from the observed) weight in pounds and $x$ is the ehild's age (measured in units of 1 month) when the weighing was made.

The parameters $a$ and $e^{b}$ have the following meaning: $a$ is the value of $y$ when $x$ equals $0.0 ; e^{b}=y(n+1) / y_{n}$. In this problem the parameter $e^{b}$ may be considered an arithmetic estimate of the child's weight at any given age expressed as a proportion of his weight the preceding month. If the child exhibits a continuous weight gain from month to month, $e^{b}$ is greater than 1.0 ; the larger $e^{b}$, the more rapidly the child is gaining. If $e^{b}$ equals 1.0 , the child's weight remains about the same throughout the period of observation. If $e^{b}$ is less than 1.0 , the ehild is actually losing weight.

Since $e$ is a mathematical constant (2.718), the value of $e^{b}$ is determined by the value of the exponent, $b$, which is the relative instantaneous veloeity $\left(\frac{d y}{d x} / y\right)$. In other words, it is an estimate of the ehild's average percentage gain or loss in weight per month during the period of observation. For example, if $b$ equals $0.008(0.0077)$ or eight-tenths of 1 pereent, the child's weight inereased at a rate of 0.8 pereent per month. In other words, if he weighed 50 pounds at 6 years 6 months of age, he probably weighed about 50.4 pounds at 6 years 7 months.

The parameters, $b$ and $a$, have been determined under a least-squares criterion, as is illustrated in the following sample ealculation and graph based on the observations for A. R., the Italian boy whose measurements liave also been used to illustrate other parts of the text:

\footnotetext{
3 Weights were taken at 4 -month intervals, at the time both annual physical cxaminations were made, and about 6 months after the first physieal examination.

4 Number of weighings, period of obecrvation, and dates are average figures. For more detailed deseription of these observations seo pp. 25 and 26.
} 


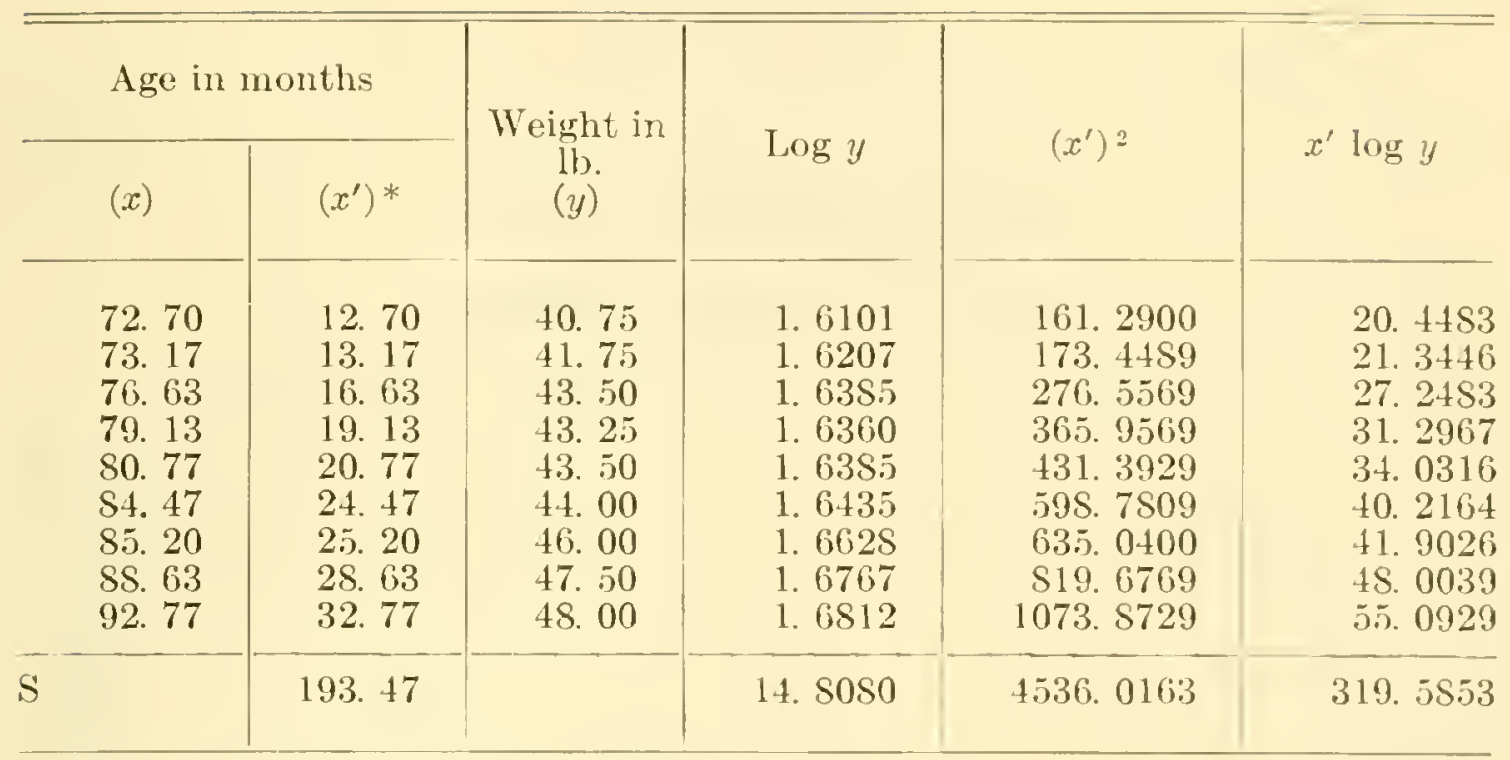

* $\mathrm{A}$ arbitrary $x$ seale $\left(x^{\prime}\right)$ has been used, with 60 months equal to 0.

Normal equations:

Solving:

$$
\begin{aligned}
& 14.80 S 0=9 \quad \log a+193.47 \quad b \log e \\
& 319.5853=193.47 \quad \log a+4536.0163 \quad b \log e
\end{aligned}
$$

and

$$
\begin{aligned}
& b=0.007711 \\
& a=37.44
\end{aligned}
$$

$$
y=37.44 e^{0.007711 x}
$$

Therefore, during the 20-month period of observation from 72.7 to 92.8 months of age, A. R.'s weight inereased on the average 0.77 percent per month.

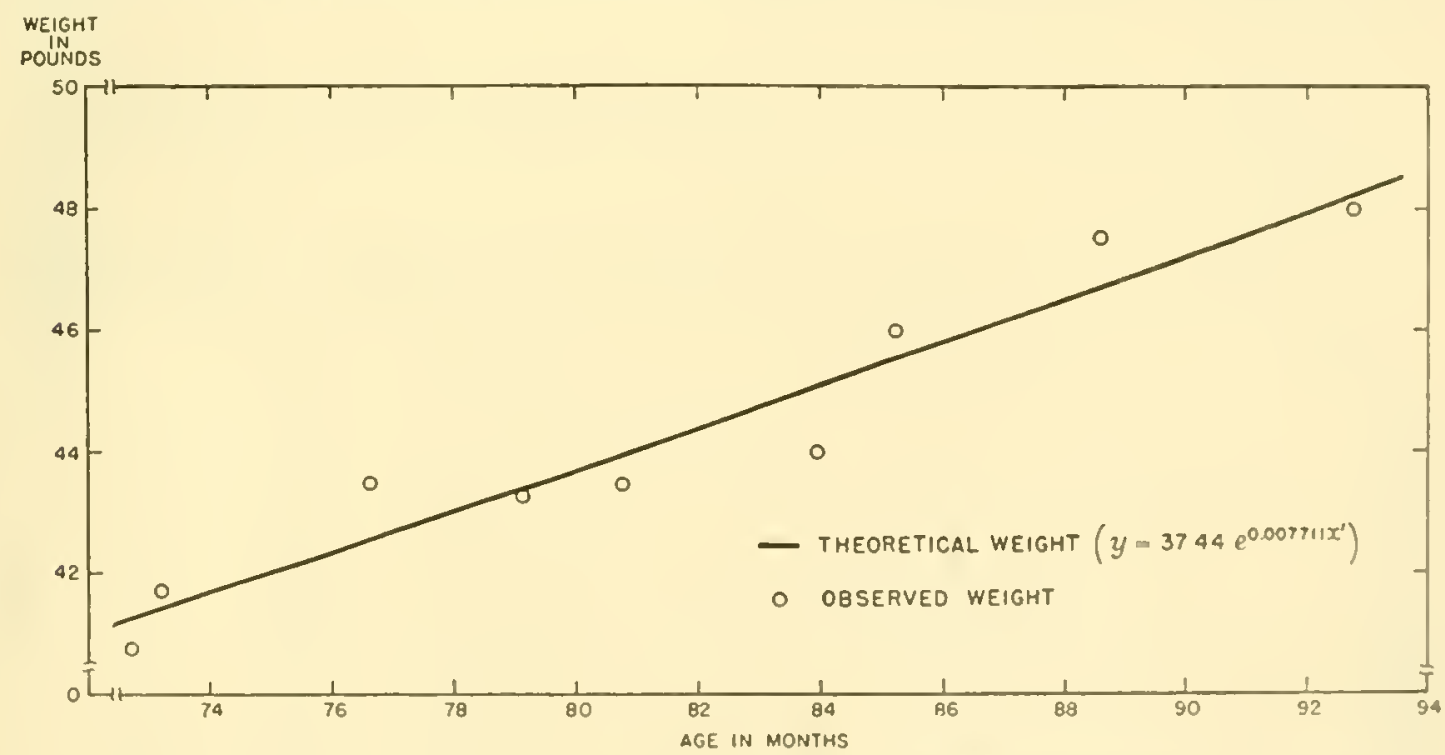

Weight of Italian Boy, A. R., Observed at Frequent Intervals From 72.7 to 92.8 Months of Age 


\section{Supplementary Tables}

\section{MATERIAL AND METHODS}

Supplenentary taBle I.-Nationality of the boys and girls

\begin{tabular}{|c|c|c|c|c|c|c|}
\hline \multirow{2}{*}{ Nalionality 1} & \multicolumn{2}{|c|}{ Both sexes } & \multicolumn{2}{|c|}{ Boys } & \multicolumn{2}{|c|}{ Girls } \\
\hline & Number & Percent & Number & Percent & Number & Percent \\
\hline Total & 713 & 100.0 & 365 & 100.0 & 348 & 100.0 \\
\hline $\begin{array}{l}\text { Italian } \\
\text { American } \\
\text { Russian } \\
\text { Mixed European }{ }^{2} \\
\text { Polish } \\
\text { Irish } \\
\text { Mixed North European }{ }^{3} \\
\text { North European }{ }^{4} \\
\text { Central European } \\
\text { South European }\end{array}$ & $\begin{array}{r}330 \\
130 \\
66 \\
59 \\
35 \\
34 \\
24 \\
17 \\
9 \\
9\end{array}$ & $\begin{array}{r}46.3 \\
18.2 \\
9.3 \\
8.3 \\
4.9 \\
4.8 \\
3.4 \\
2.4 \\
1.2 \\
1.2\end{array}$ & $\begin{array}{r}166 \\
65 \\
34 \\
34 \\
19 \\
17 \\
12 \\
6 \\
5 \\
7\end{array}$ & $\begin{array}{r}45.5 \\
17.9 \\
9.3 \\
9.3 \\
5.2 \\
4.7 \\
3.3 \\
1.6 \\
1.4 \\
1.9\end{array}$ & $\begin{array}{r}164 \\
65 \\
32 \\
25 \\
16 \\
17 \\
12 \\
11 \\
4 \\
2\end{array}$ & $\begin{array}{r}47.1 \\
18.7 \\
9.2 \\
7.2 \\
4.6 \\
4.9 \\
3.4 \\
3.2 \\
1.1 \\
.6\end{array}$ \\
\hline
\end{tabular}

1 Classification was based on the birthplace of 3 of the child's grandparents. The classification "American" includes not only children 3 of whose grandparents were born in the United States but also children whose parents and 2 of whose grandparents were born here.

2 Did not have 3 grandparents from any 1 country.

3 grandparents from various North European countries.

43 grandparents from 1 North European country.

53 grandparents from 1 Central European country.

63 grandparents from 1 South European country.

SUPPLEMENTARY TABLE II.-Bitrochanteric widths of the boys and girls

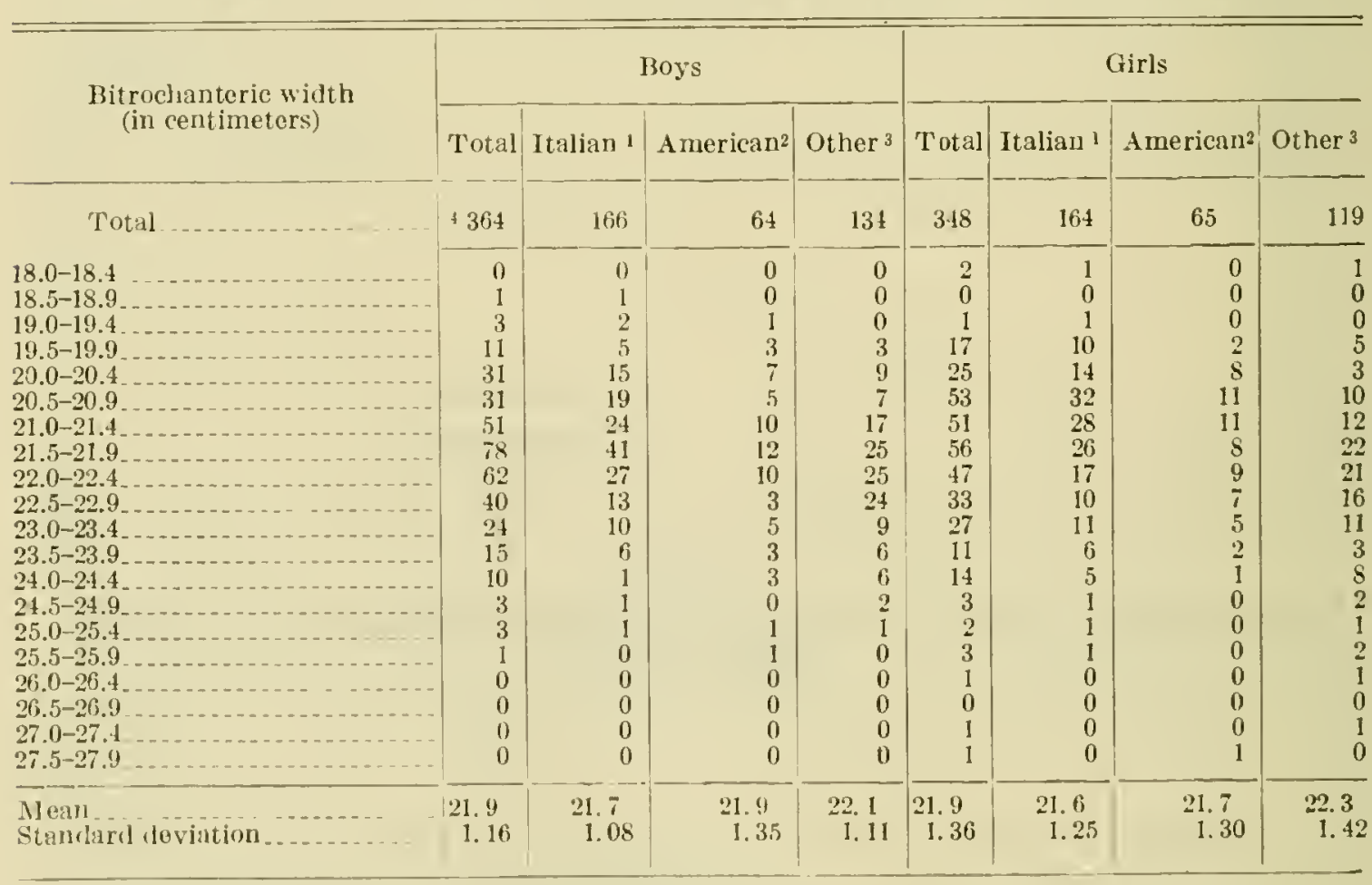

13 of the child's grantpurents were horn in Italy.

23 of the child's grand larents or 2 of his grandparents and both his marents were born in the United States.

3 Theso children clid not meet the lefinitions outlined in footnotes 1 and 2.

4 Jitrochanteric width was unknowi for 1 boy. 


\section{RESULTS}

\section{Growth estimates used in deriving Criteria III, IV, and $V$.}

Supplementaky table III.-Average percentage gain in weight per month of the boys and girls

\begin{tabular}{|c|c|c|}
\hline A verage percentage gain & Boys & Girls \\
\hline 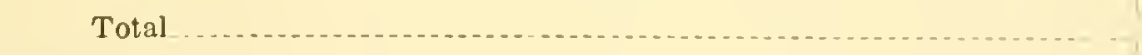 & 365 & 345 \\
\hline $\begin{array}{l}0.20-0.39 \\
0.40-0.59 \\
0.60-0.79 \\
0.80-1.99 \\
1.00-1.19 \\
1.20-1.39 \\
1.40-1.59 \\
1.60-1.79 \\
1.80-1.99 \\
2.00-2.19 \\
2.20-2.39\end{array}$ & $\begin{array}{r}1 \\
106 \\
144 \\
63 \\
20 \\
9 \\
1 \\
0 \\
1 \\
0\end{array}$ & $\begin{array}{r}2 \\
13 \\
90 \\
127 \\
64 \\
22 \\
16 \\
6 \\
3 \\
0 \\
1\end{array}$ \\
\hline
\end{tabular}

Sopplementary Table IV.-Percentage change in arm girth per year of the boys and girls

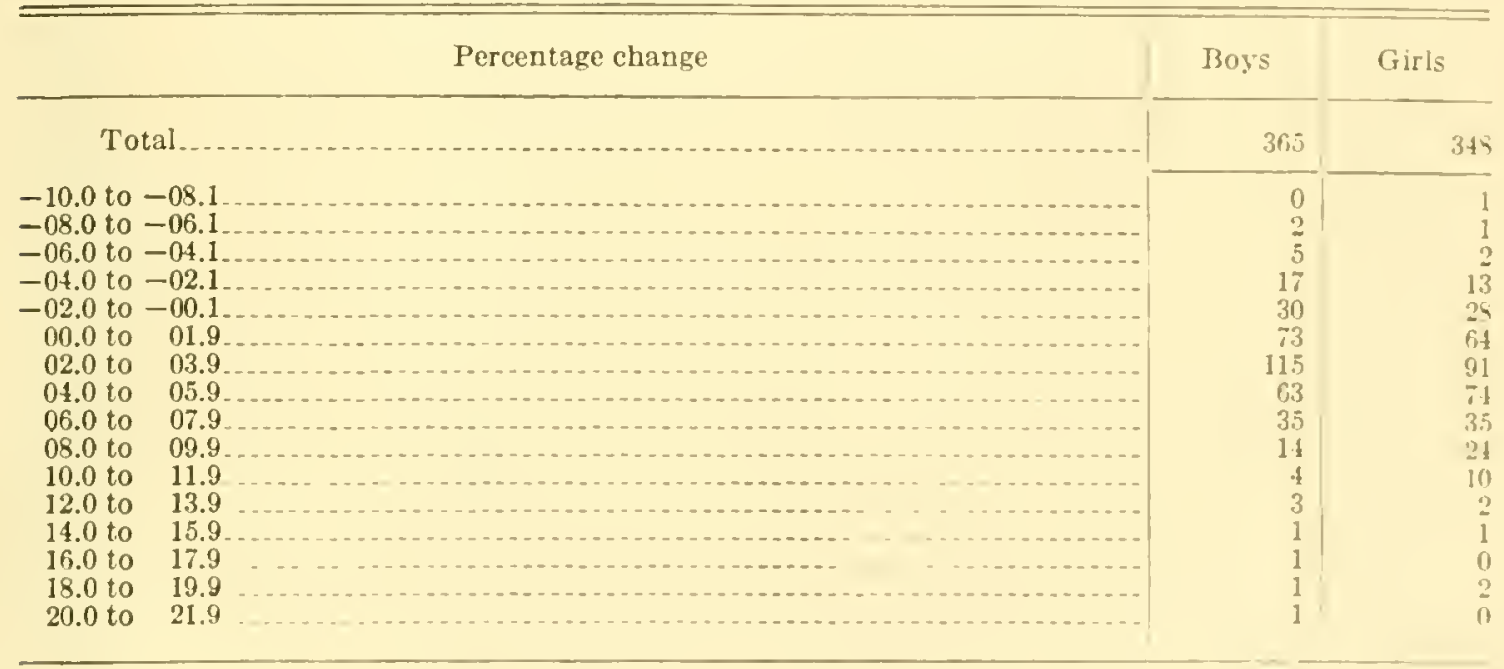




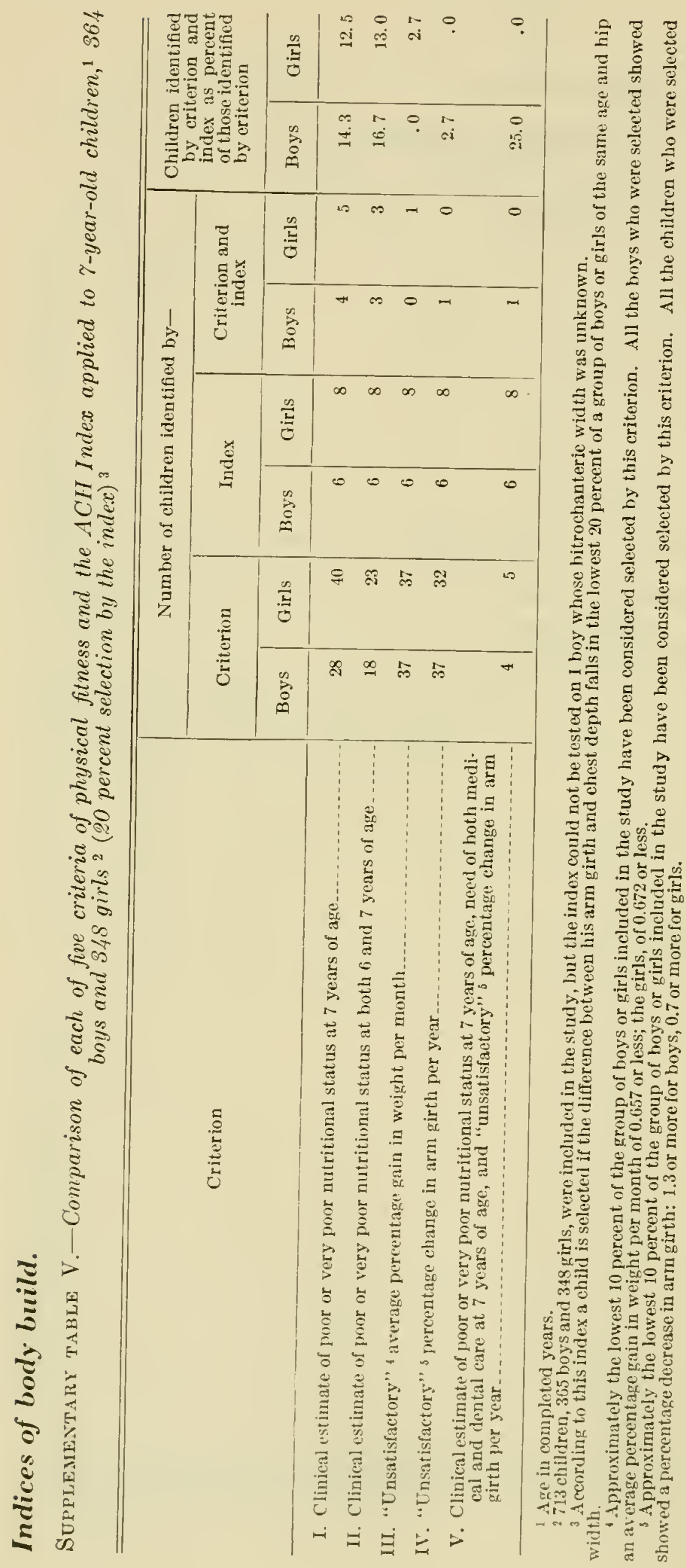




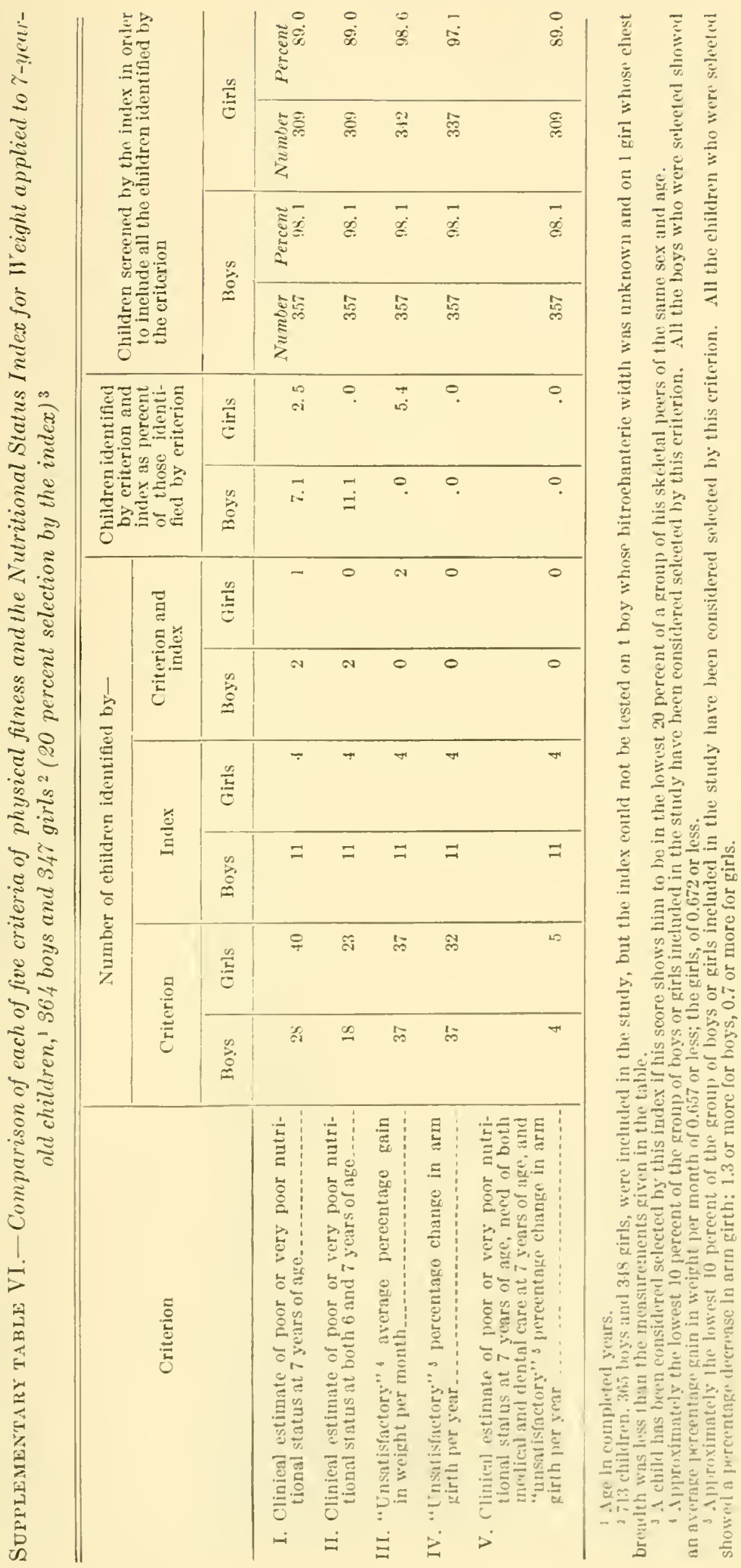


104 ASSESANG THE PHYSICAL FITNESS OF CHILDREN

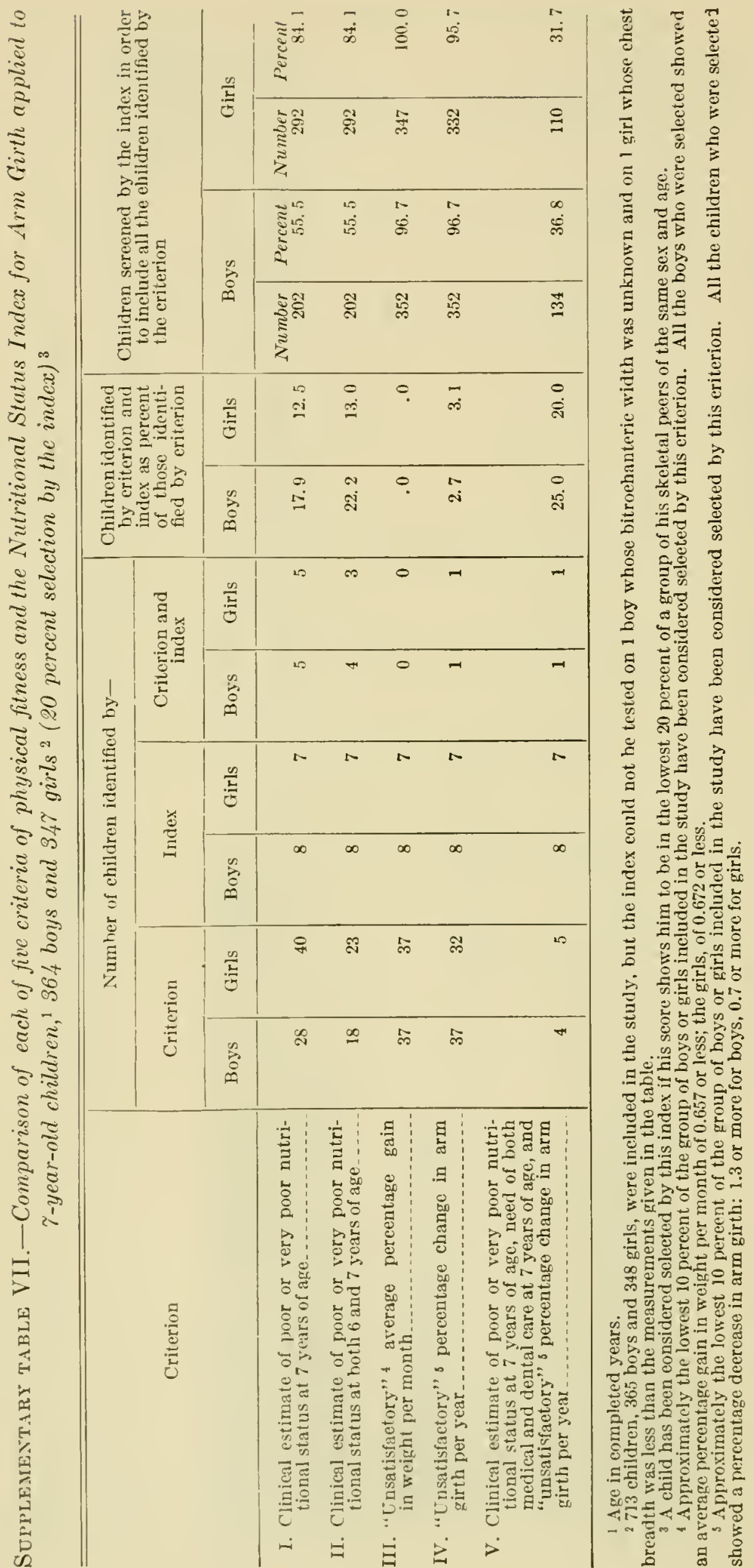




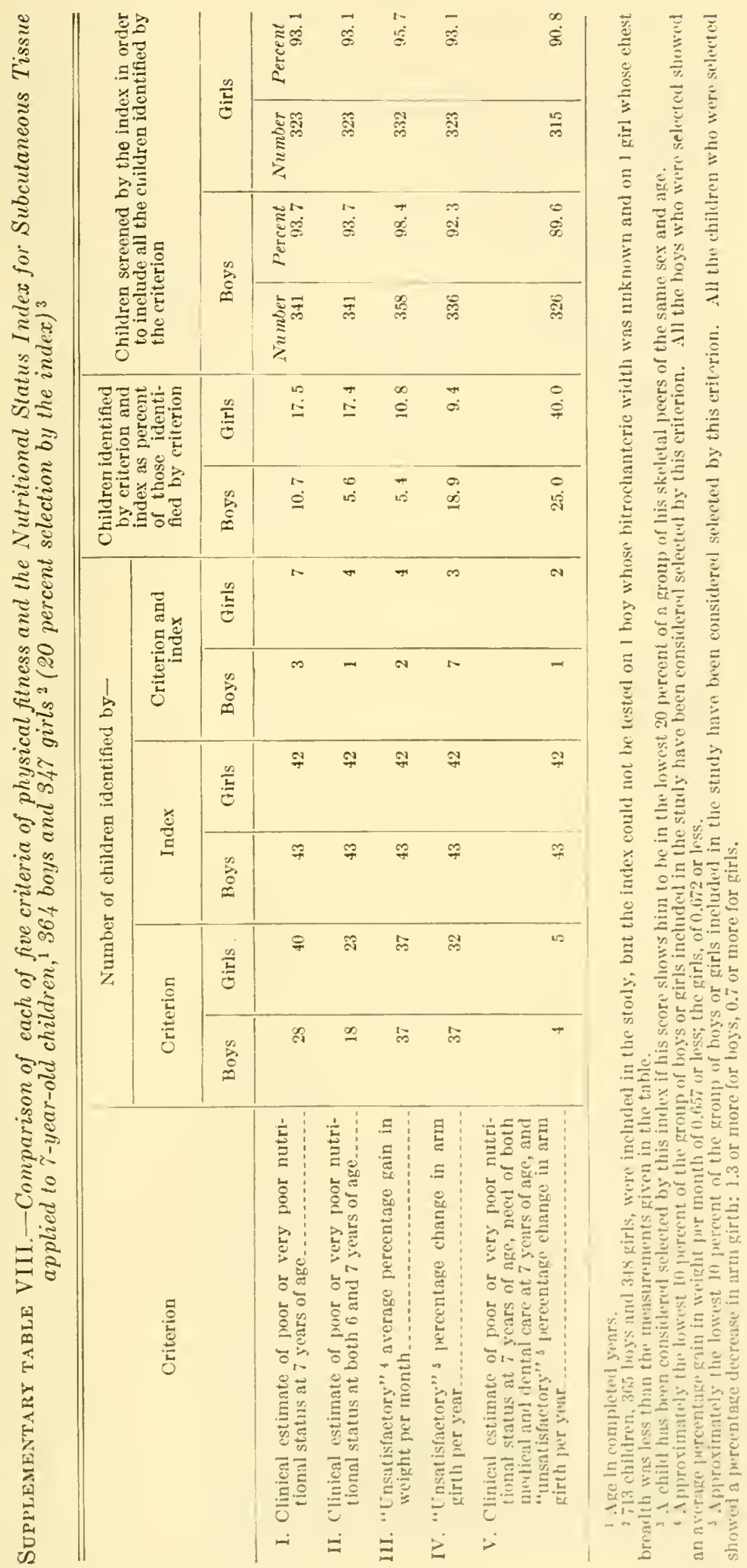




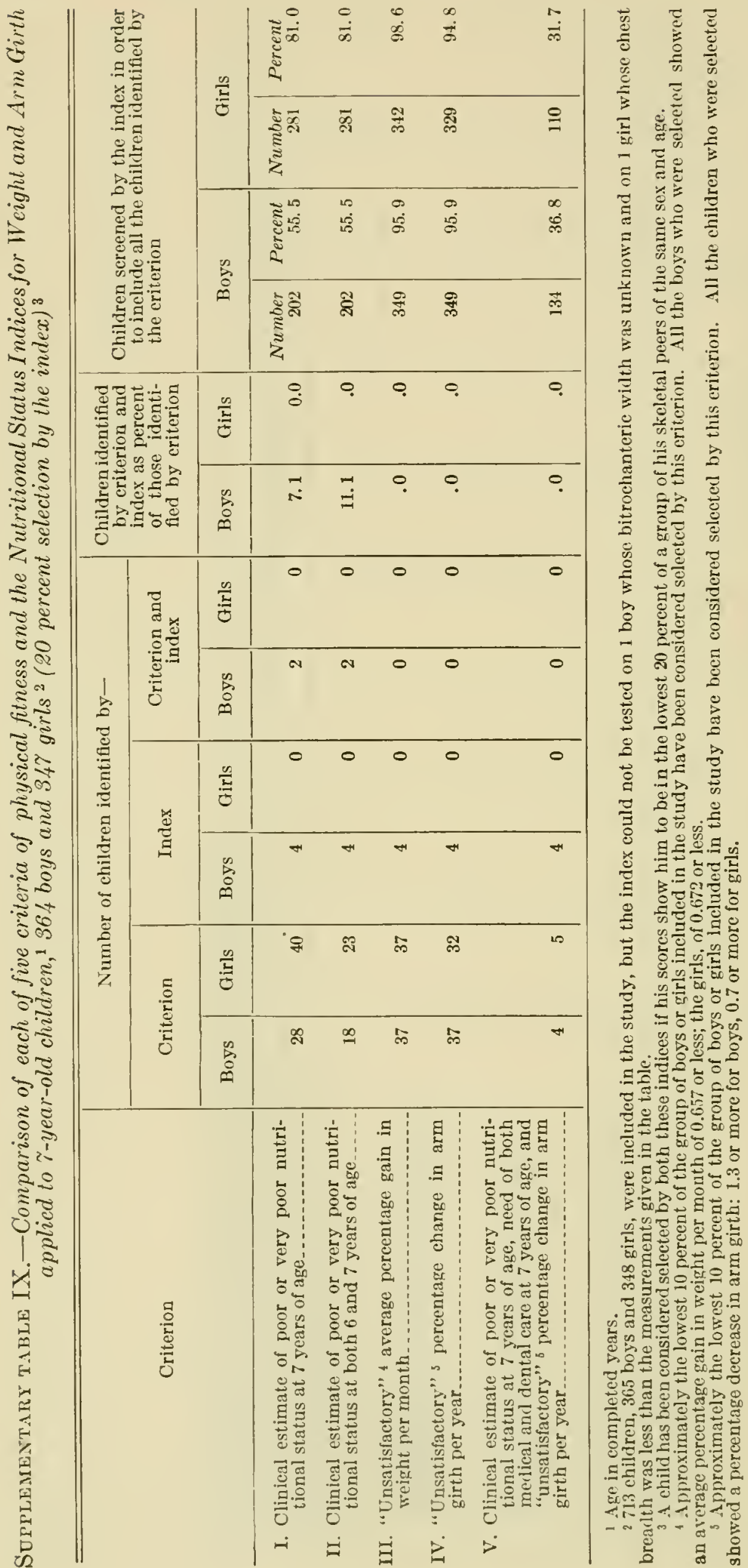




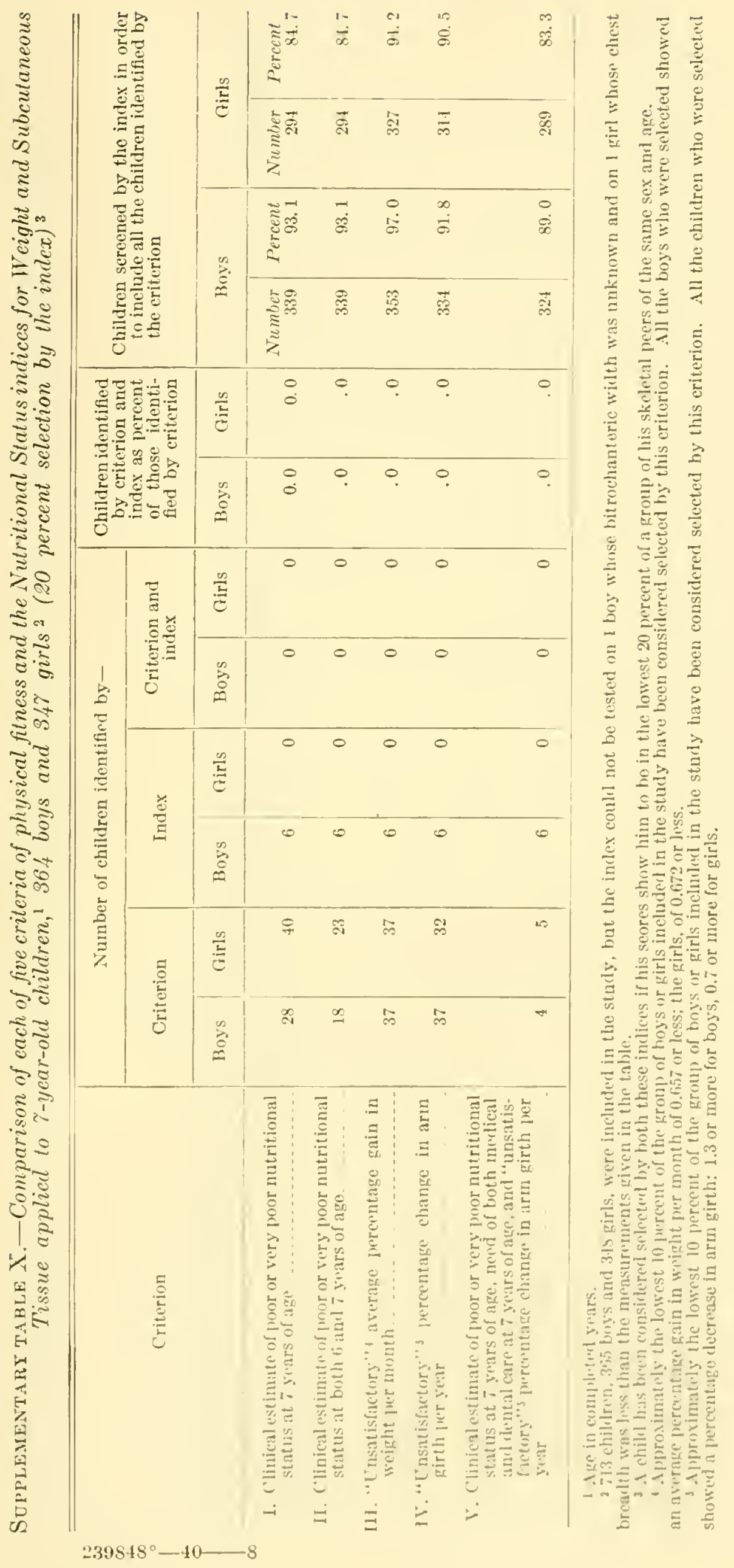




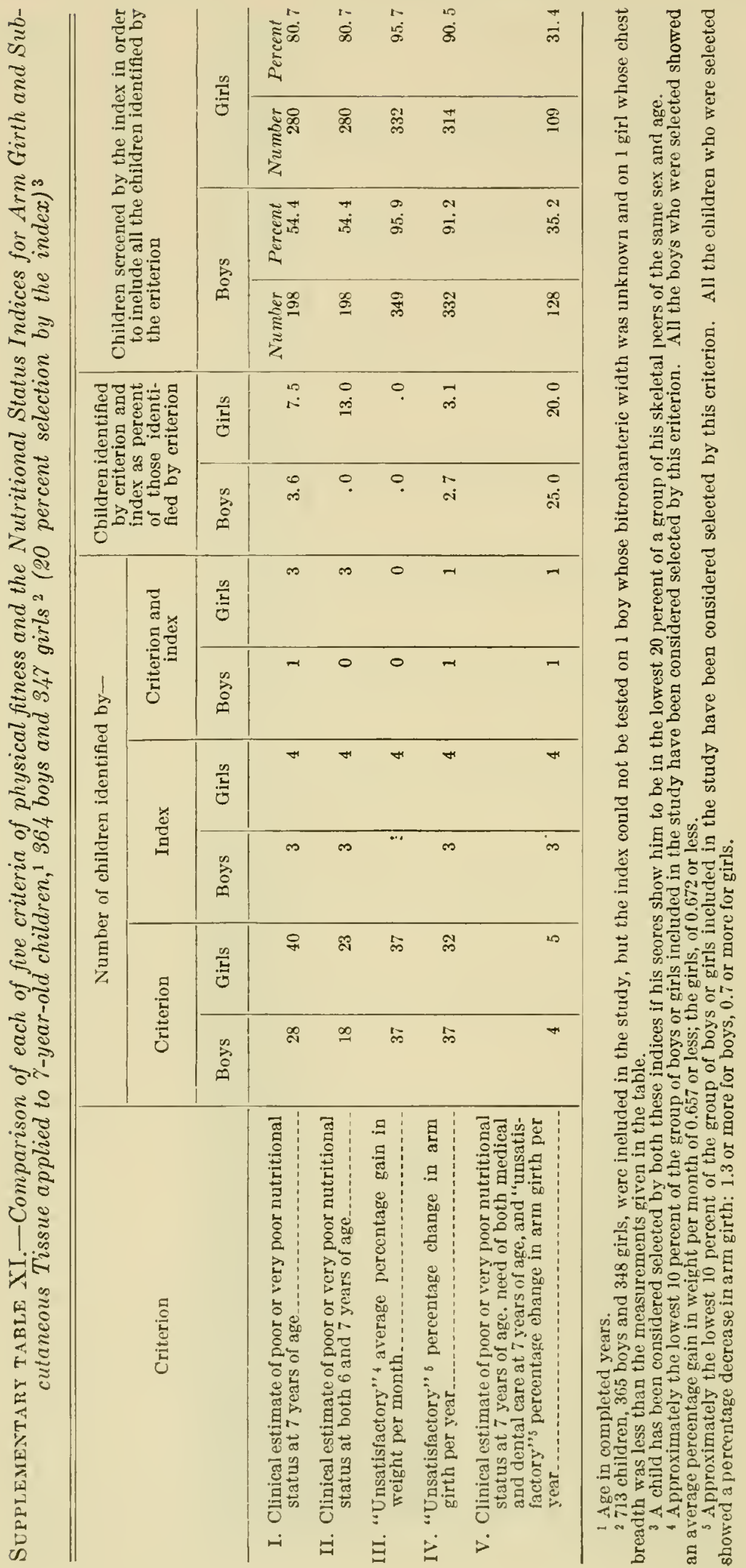




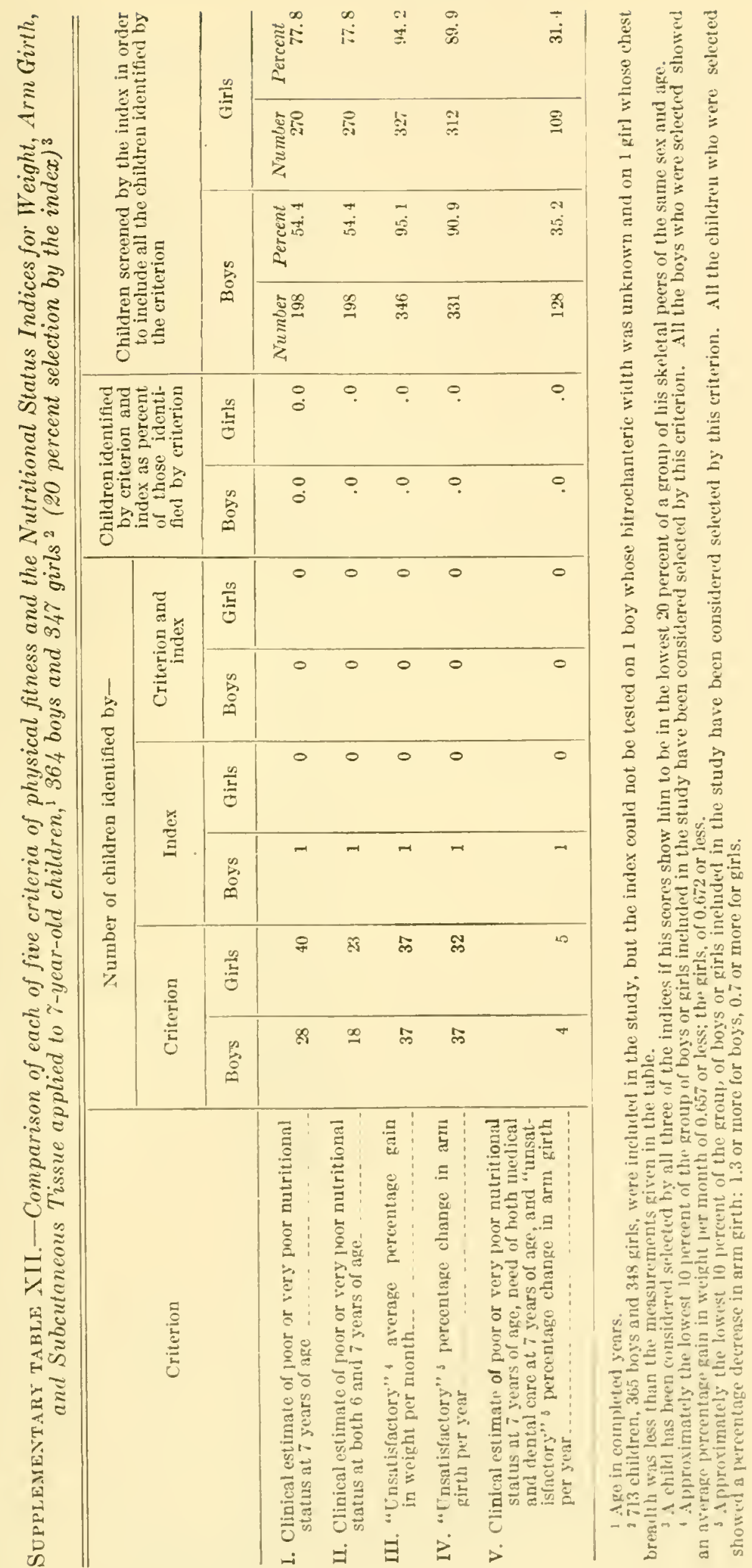


110 ASSESSING THE PHYSICAT FITNESS OF CHILDREN

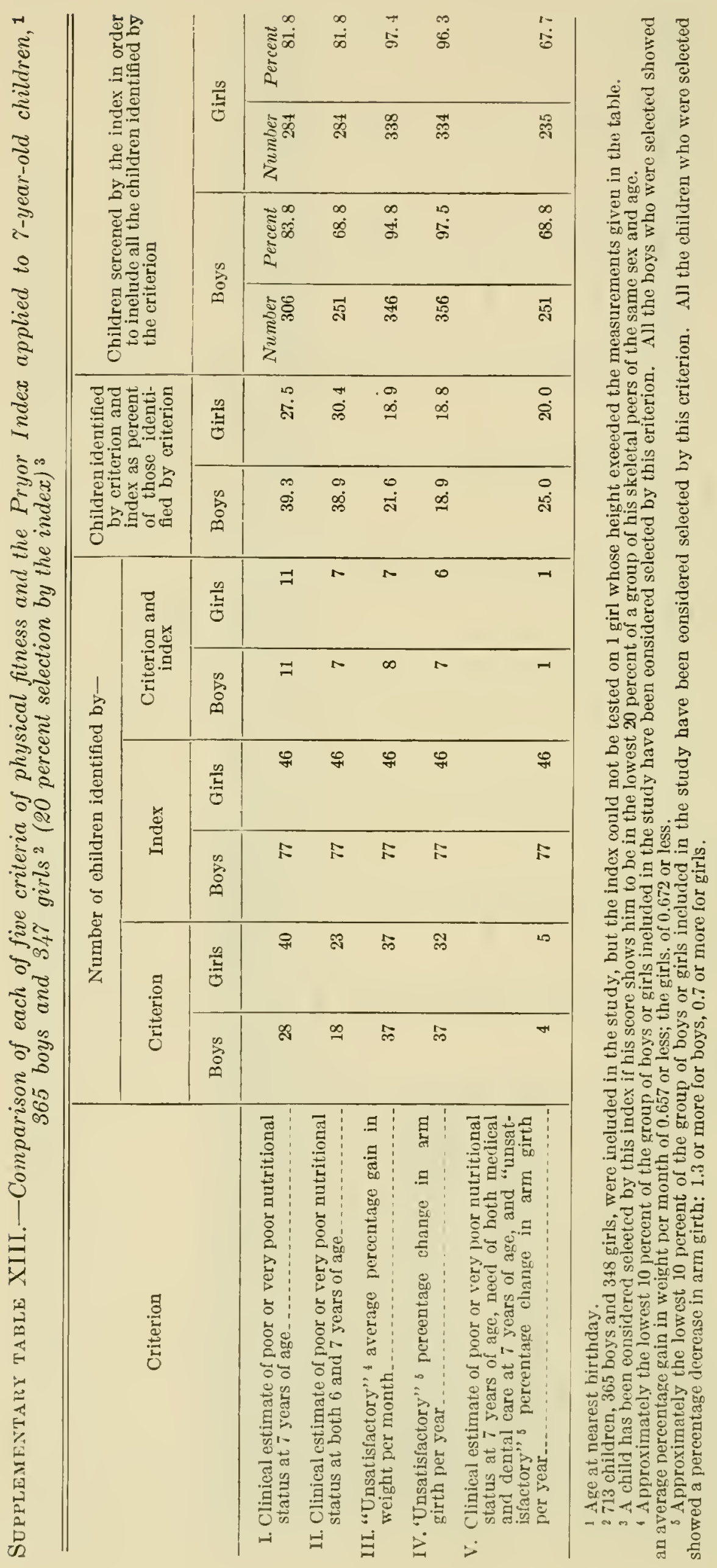


Supplementary table XIV.-Baldwin-Wood Index for the boys and girls

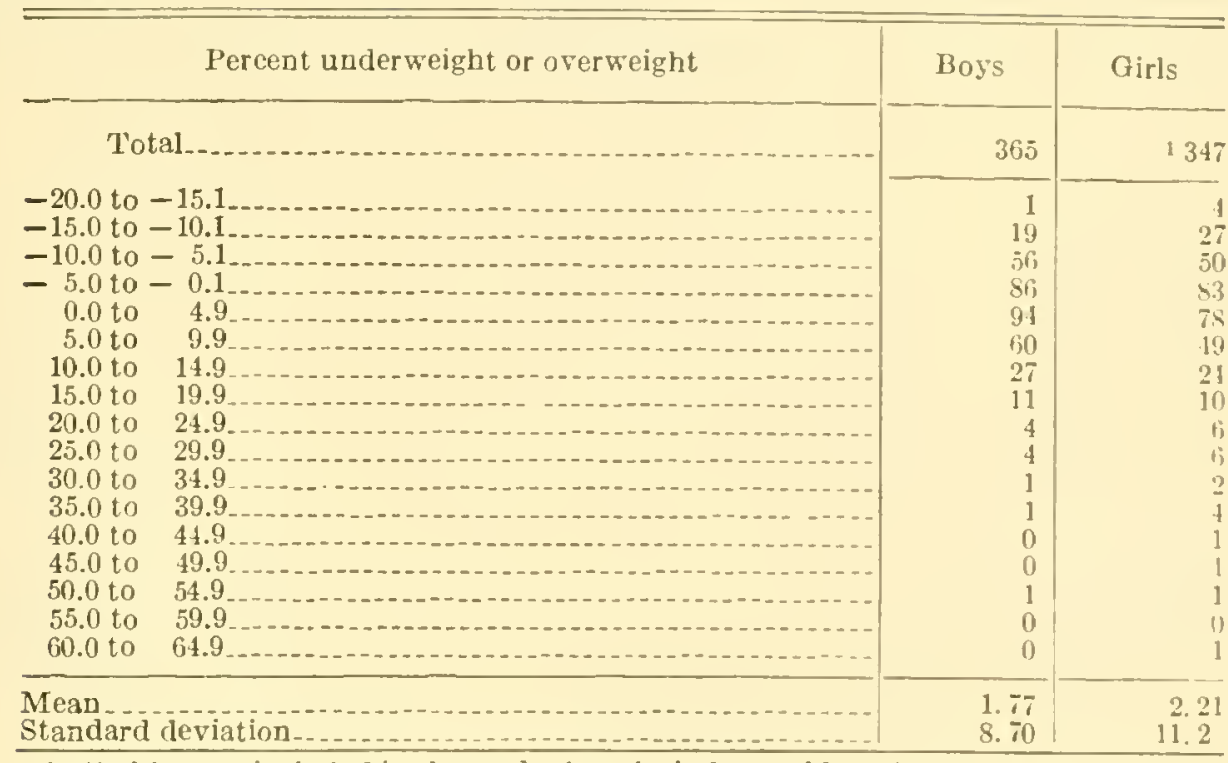

1348 girls were included in the study, but the index could not be iested on 1 girl whose height exceeded the measurements given in the table.

Sopplementary table XV.- Nutritional Stalus Index for Weight of the boys and girls

\begin{tabular}{|c|c|c|}
\hline$x / \sigma 1$ & Boys & Girls \\
\hline Total ... ... & 364 & 2347 \\
\hline 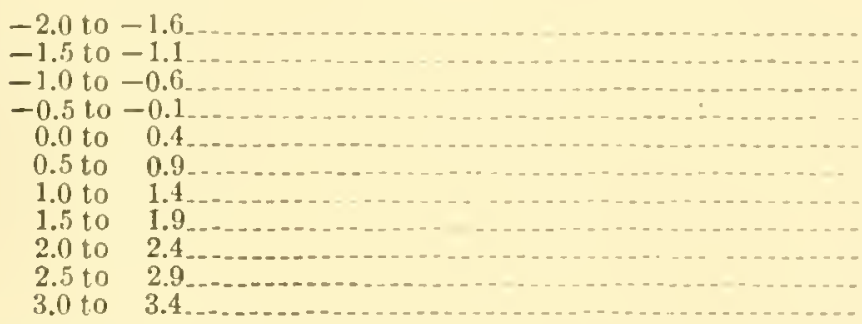 & $\begin{array}{r}1 \\
3 \\
18 \\
43 \\
91 \\
95 \\
62 \\
33 \\
10 \\
3 \\
2\end{array}$ & $\begin{array}{r}0 \\
11 \\
11 \\
34 \\
91 \\
9: \\
56 \\
35 \\
10 \\
2 \\
5\end{array}$ \\
\hline $\begin{array}{l}\text { Mean } \\
\text { Standard deviation. }\end{array}$ & $\begin{array}{l}0.6 .52 \\
0.763\end{array}$ & $\begin{array}{l}0.715 \\
11.7-72\end{array}$ \\
\hline
\end{tabular}

1 See Appendix II: (75) Nutritional Status Indices, p. 6.5. Table $\mathrm{X}$ gives the child's index or score according to an arbitrary scale which may be expressed in ternss of the abscissa of the normal curve. Table $X$ seore $=1 n x / \sigma+i n$.

2365 hoys and 318 girls were included in the study, but the index eould not be tested on I boy whose bitrochanteric width was unknown and on 1 girl whose chest brealth was less than the measurements given in the table.

SUPP lementary Tarle XVI.-Nutritional Status Index for subcutaneous Tissue of the boyss and girls

\begin{tabular}{|c|c|c|}
\hline$x / \sigma$ & Boy's & (iirls \\
\hline Total & 23ril & $: 317$ \\
\hline 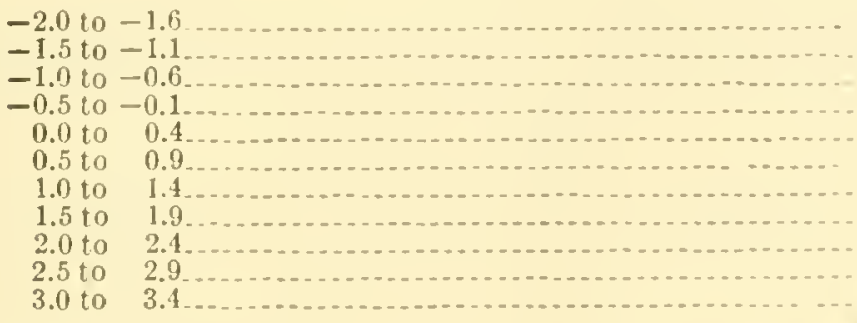 & $\begin{array}{r}11 \\
14 \\
111 \\
82 \\
43 \\
11 \\
5 \\
1 \\
0 \\
11\end{array}$ & $\begin{array}{r}22 \\
23 \\
104 \\
10 \\
11 \\
11 \\
15 \\
7 \\
11 \\
1 \\
1\end{array}$ \\
\hline $\begin{array}{l}\text { Mean } \\
\text { Standard deriation }\end{array}$ & $\begin{array}{l}-11.10103 \\
\text { (1) }\end{array}$ & $\begin{array}{r}-0,0137 \\
\text { (1) } \quad \text { i.t. }\end{array}$ \\
\hline
\end{tabular}

1 Ser footmote 1, supplementary tahle XV.

2365 boys and 345 girla were included in the stud 5 , but the inder enuld unt be tectorl on

1 boy whose bitrochanterlc width was unknown and on 1 girl whose chest hreadth was

less than the measurements given in the tahle. 
Supplementary table XVII. - Nutritional Status Index for Arm Girth of the boys and girls

\begin{tabular}{|c|c|c|}
\hline$x / \sigma 1$ & Boys & Girls \\
\hline 'Total. & ${ }^{2} 364$ & 347 \\
\hline 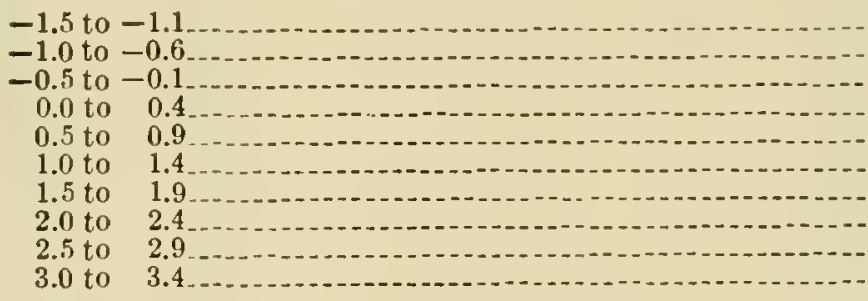 & $\begin{array}{r}4 \\
8 \\
32 \\
48 \\
79 \\
81 \\
60 \\
33 \\
7 \\
12\end{array}$ & $\begin{array}{r}2 \\
18 \\
34 \\
86 \\
70 \\
55 \\
46 \\
21 \\
8 \\
7\end{array}$ \\
\hline $\begin{array}{l}\text { Mean } \\
\text { Standard deviation }\end{array}$ & $\begin{array}{l}1.07 \\
0.904\end{array}$ & $\begin{array}{l}0.838 \\
0.905\end{array}$ \\
\hline
\end{tabular}

1 See footnote 1 , supplementary table $\mathrm{XV}$.

2365 boys and 348 girls were included in the study, but the ind ex could not be tested on 1 boy whose bitrochanteric width was unk nown and on 1 girl whose chest breadth was less than the measurcments given in the table.

SUPPLementaRy TABLE XVIII.-Pryor Index for the boys and girls

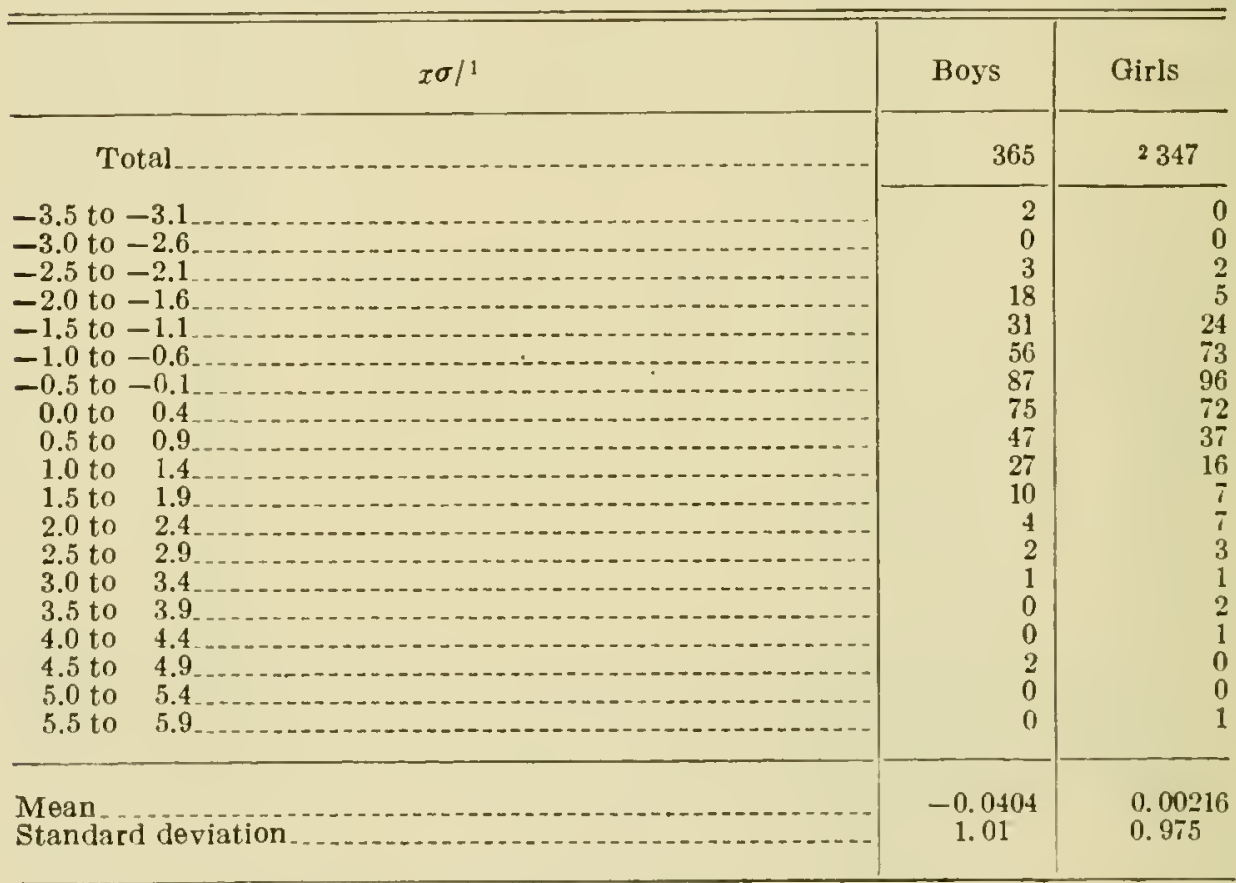

1 For procedure followed in computing $x / \sigma$ values see A ppendix I, pp. 97-98.

2348 girls were included in the study, but the index could not be testerl on 1 girl whose height exceeded the measurements giren in the tahle.

\section{Clinical judgment of general nutritional status.}

SUPplementari TABLE XIX.-Association between the estimates made by pediatricians $A$ and $B$ of the nutritional status of 107 boys at the chech-up examinations

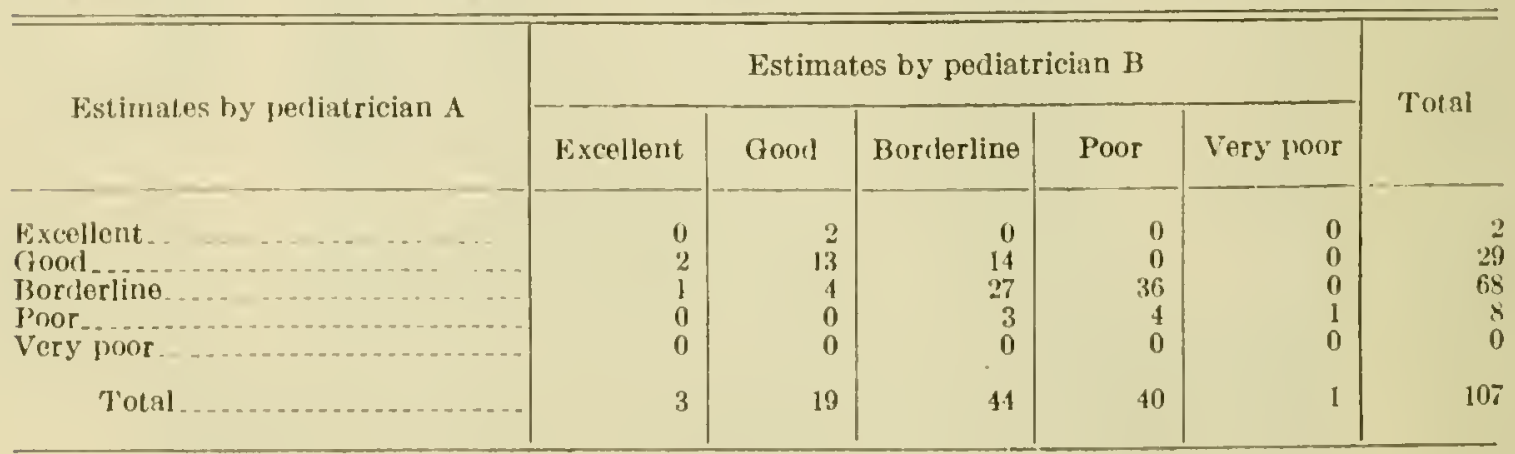


Sopplementary Table XX.-Association between the estimates made by pediatricians $A$ and $B$ of the nutritional status of 101 girls at the check-up examinations

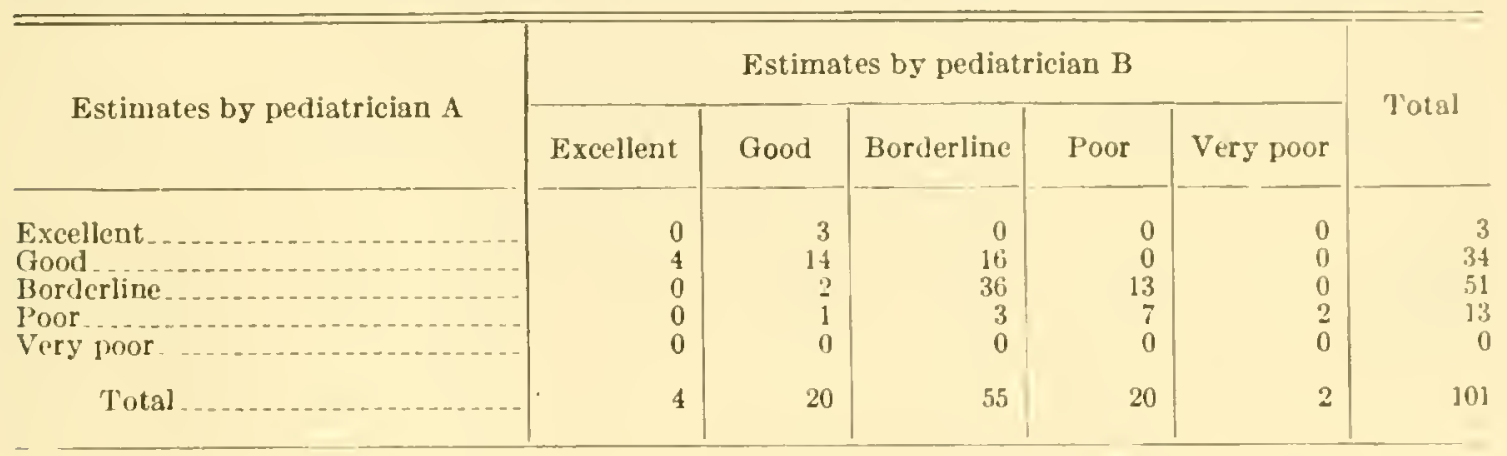

Supplementary table XXI.-Association between the estimates made by pediatricians $A$ and $C$ of the nutritional status of 107 boys at the check-np examinations

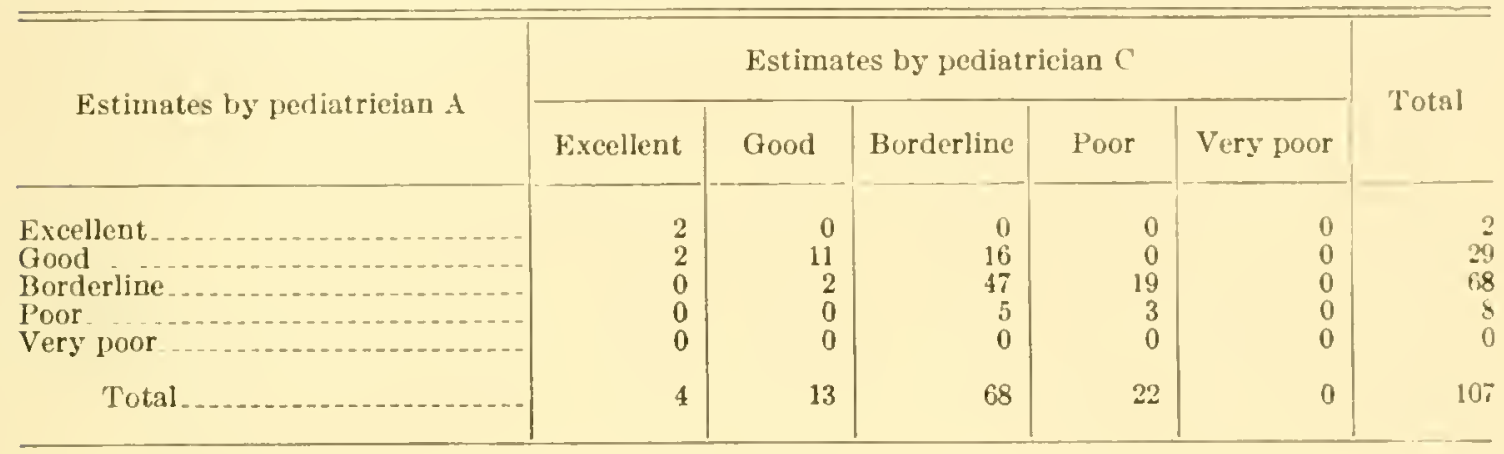

SUPllementary TABLE XXII.-Association between the estimates made by pediatricians $A$ and $C$ of the nutritional status of 101 girls at the check-up examinations

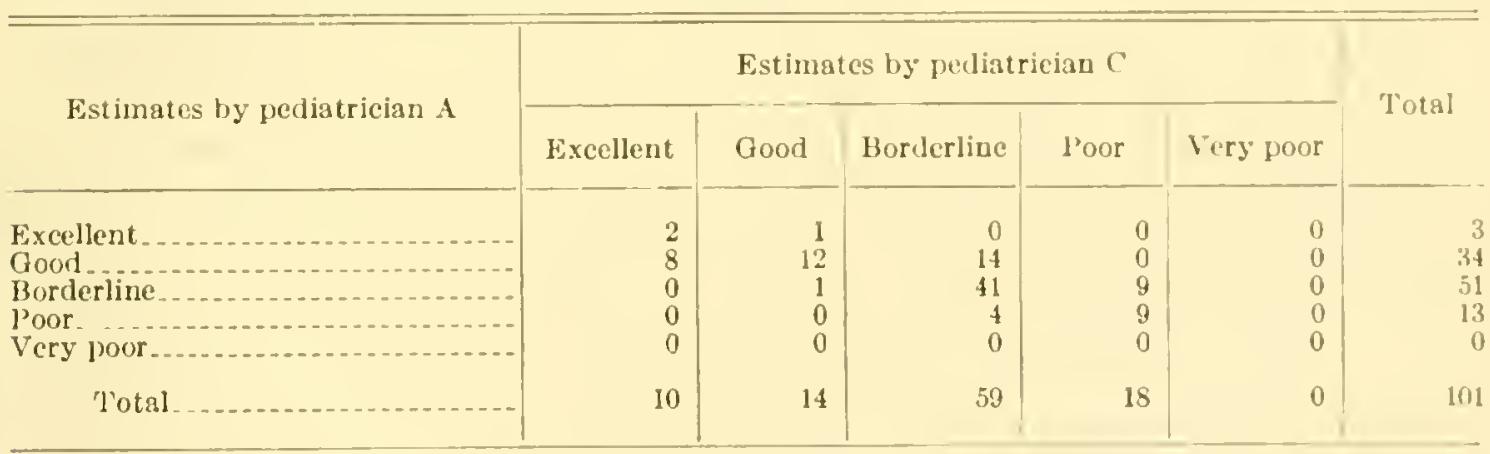

SUPPLEMETARY TABLE XXIII.-Association between the estimates made by pediatricians $B$ and $C$ of the nutritional status of 107 boys at the chech-up examinations

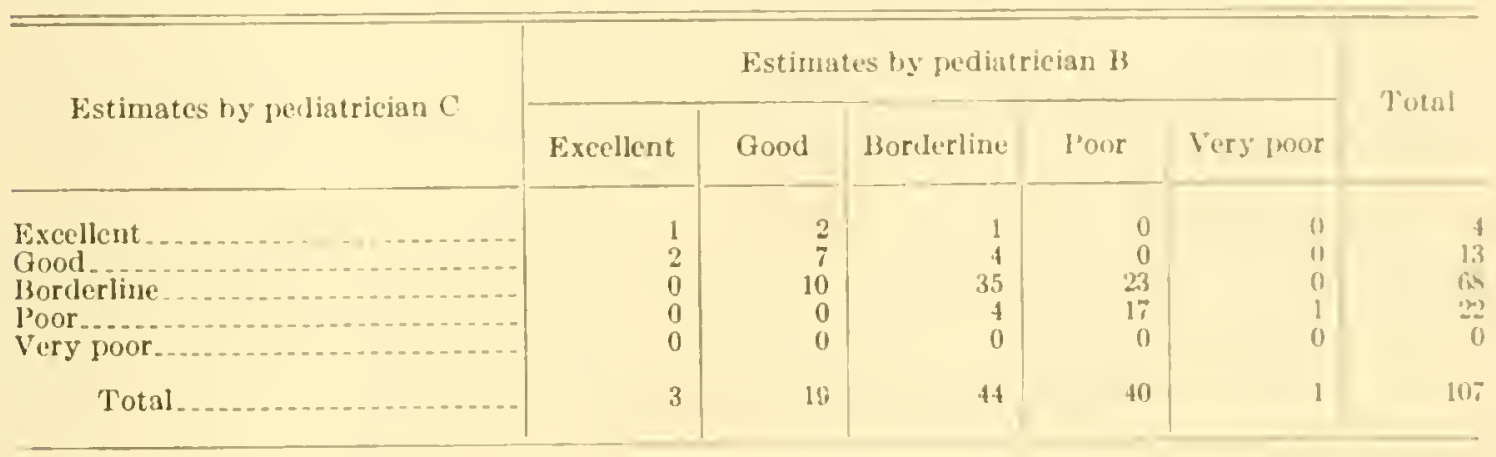


SUPPLEMENTARY TABLE XXIV.-Association between the estimates made by pediatricians $B$ and $C$ of the nutritional status of 101 girls at the check-up examinations

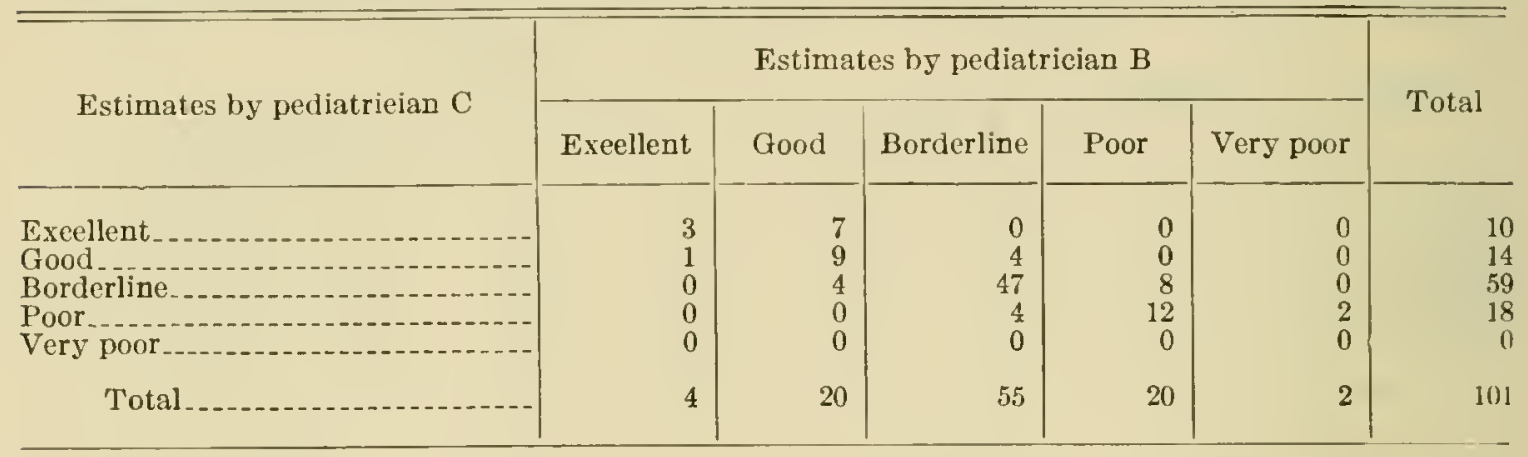




\section{Appendix II List of References ${ }^{1}$}

(1) ALLMAN, D. I., Comparison of mutritional indices, Researcli Quart. 8: 79-93, May' '37

(2) AYKROYD, W. R., Assessment of "state of nutrition" and detection of malnutrition, Brit. M. J. 2: 1008-1010, Nov. 20, '37

(3) - MADHAVA, K. B., and RAJAGOPAL, K., Detection of mahnutrition by measurements of arm, ehest and hip, Indian J. M. Research 26: 55-94, July '3s

(4) - and RAJAGOPAL, K., State of nutrition of sehool ehildren in South India, Indian J. M. Research 24: 419-437, Oct. '36

(5) BALDWIN, B. T., Use and abuse of weight-height-age tables as indexes of health and nutrition, J. A. M. A. $82: 1-4$, Jan. 5, '24

(6) - and WOOD, T. D., Weight-height-age tables; tables for boys and girls of school age, Mother and Child 4 : supplement to July' '23 issue

(7) BARDEEN, C. R.: See reference contained in (8Z) Paton and Findlay

(8) Betenson, W. F. W., County Medical Officer of Health, and School Medieal Officer, Walton, Brecon, England, Personal communication, dated Jan. 26, '38

(9) BIGWOOD, E. J., Guiding Principles for Studies on the Nutrition of Popılations. Teehnical Commission on Nutrition. League of Nitions Health Organization. PP. 281. Geneva, 1939

(10) BOONE, B. R., and CIOCCO, A., Cardiometric studies on children, I. Stethographic patterns of heart sounds, observed in 1,482 children, Milbank Memorial Fund Quart. 17:323-357, Oet. '39

(11) BOUDREAU, F. G., and KRUSE, H. D., Malnutrition-a challenge and an opportunity, Am. J. Pub. Health 29:427-433, May' '39

(12) BOYD, E., Experimental error inherent in measuring the growing human body, Am. J. Plyys. Anthropol. 13: 389-432, Oct.-Dec.'29

(13) BREWER, D., Development of school medicine, M. Officer 60:91-93, Aug. $27, ' 38$

(14) BRITISH MEDICAL ASSOCIATION, Report of Committee on Nutrition: Sce reference contained in (44) Harris, pp. 237-240, Dec. 4, '37

(15) BRITTEN, R. H., Senior Statistician, National Institute of Health, U. S. Public Health Service, Personal communication, dated June 1, '39

(16) BUCK, C. E., Health Survey of the State of New Mexico; a survoy sponsored by New Mexico Tuberculosis Association and published by authority of New Mexico State Planning Board. Pp. 35. Santal Fe: New Mexico Pub. Corp. [1933]

(17) CATHCART, E. P., Medieal aspects of nutrition, in Nitional Conference on the Wider Aspects of Nutrition, Apr. 27-28-29, 1939. [Proceedings]: Nutrition and the Public Healtl; medicine, agriculture, industry, edueation. Pp. 17-24. London: British Medical Association, 1939

\footnotetext{
1 This list follows the style of the Quarterly Cumblative Intex Medicus fmblished by the American Medical $\Lambda$ ssociation, Chicago.
} 
(18) ChatterJI, A. C., I. M.S., Director of Health for Bengal, Calcutta, India, Personal communication, dated May 15, '39, concerning a nutritional survey in Bengal, India

(19) Cheesman, J. E., Asst. School Medical Officer, Kent County, England, Personal communication, dated Feb. 4, '39

(20) CLARK, F. LE GROS, National Fitness; a brief essay on contemporary Britain. Pp. xii + 222. London: Macmillan, 1938

(21) CLARK, T., SYDENSTRICKER, E., and COLLINS, S. D., Indices of nutrition; the application of certain standards of nutrition to 506 native white children without physical defects and with "good" or "excellent" nutrition as judged from clinical evidence, Pub. Health Rep. 38: 1239-1270, June 8, '23

(22) - New Baldwin-Wood weight-height-age tables as an index of 'nutrition; the application of the Baldwin-Wood standard of nutrition to 506 native white children without physical defects and with "good" or "excellent" nutrition as judged from clinical evidence, Pub. Health Rep. 39: 518-525, Mar. 14, '24

(23) CLEMENTS, F. W. : See reference to study using ACH Index contained in (99) Scantlebury

(24) CORRY MANN, H. C.: See reference contained in (44) Harris, pp. 261-265, Dec. 18, '37

(25) DERRYBERRY, M., Reliability of medical judgments on malnutrition, Pub. Health Rep. 53: 263-268, Feb. 18, '38

(26) DREIS, T. A., A Handbook of Social Statistics of New Haven, Conn. Published for the Yale University Institute of Human Relations. Pp. xiii + 146. New Haven: Yale University Press, 1936

(27) DREYER, G., The normal vital capacity in man and its relation to the size of the body, Lancet 197: 227-234, Aug. 9, '19

(28) DUBLIN, L. I., and GEBHART, J. C., Do Height and Weight Tables Identify Undernourished Children? Pp. 23. New York: N. Y. Assn. for Improving the Condition of the Poor, 1924

(29) DUNSTAN, W. R., Clinical assessment of nutrition, M. Officer 57:55, Feb. 6, '37

(30) EMERSON, W. R. P., and MANNY, F. A., Weight and height in relation to malnutrition, Arch. Pediat. 37: 468-485, Aug. '20

(31) FABER, H. K., Variability in weight for height in children of school age, Am. J. Dis. Child. $30: 328-335$, Sept. '25

(32) FESSARD, A., IAUFER, J., and LAUGIER, H. : See reference contained in (129) Wroczynski

(33) FRANZEN, R., Selection of malnourished school children, An. J. Dis. Child. 47: 789-798, April '34

(34) Validity of comparisons of current methods for estimating physical status, Child Development 8 : 221-222, Sept. '37

(35) and PALMER, G. T., The ACH Index of Nutritional Status. Pp. 12. New York: Amcrican Child Health Assn., 1934

(36) FRIEND, G. E., The Schoolboy; a study of his mutrition, physical development and health. Pp. xii +128 . Cambridge: W. Heffer and Sons, Ltd., 1935

( 37 ) GLAZIER, M. M., Estimation of nutritional state in children, New England J. Med. 222: 180-184, Feb. 1, '40

(38) GOULD, G. M., Gould's Medical Dictionary; the words and phrases generally used in medicine and the allied sciences, with their pronunciation and derivation. Fourth edition revised by R. J. E. Scott and C. V. Brownlow. Pp. xviii + 1,538. Philadelphia: P. Blakiston's Son and Co., 1935 
(39) GREAT BRITAIN BOARD OF EDUCATION, The Health of the School Child; annual report of chief medical officer for the year 1935. Pp. 159. London: His Majesty's Stat. Off., 1936

(40) The Health of the School Child; annual report of ehief medical officer for the year 1936. Pp. 136. London: Mis Majesty's Stat. Off., 1937

(41) GREAT BRITAIN MINISTRY OF HEALTH, Advisory Committee on Nutrition, First Report. Pp. 52. London: His Majesty's Stat. Off., 1937

(42) Annual Report of Chief Medical Officer for the year 1933. Pp. 295. London: His Majesty's Stat. Off., 1934

(43) GREEN, M. E., Malnutrition Among School Children. (Reprinted from the Nutrition Report of the British Association for Labour Legislation.) Pp. 14. London: The Children's Minimum Council, 1938

(44) HARRIS, L. J., Incidence and assessment of malnutrition; eritique and review, M. Officer 58: 225-229, Nov. 27, '37; 237-240, Dec. 4, '37; 249-251, Dec. 11, '37; 261-265, Dec. 18, '37; 273-277, Dec. 25, '37

(45) HEJINIAN, L. M., and HATT, E., Stem-length; recumbent-length ratio as index of body type in young children, Am. J. Phys. Anthropol. 13:287-307. July-Sept. '29

(46) HERD, H., Discussion of paper, Assessment of nutrition, by J. G. Woolham, Pub. Health 50: 258-260, May' 37

(47) [Editorial] Indexes of nutrition. .J. A. M. A. 81: 1286-1287, Oct. 13, '23.

(48) JACOB, R., Heights and weights in a girls' public school. (Letter to the editor) Nature 142: 436-437, Sept. 3, '38

(49) JENKINS, R. L., On a distortion embodied in the Pryor-Stol\% width-weight tables, M. Rec. 146: 127-128, Aug. 4, '37

(50) JONES, R. H., The Nutrition of Liverpool Schoolboys in Relation to Certain Physical Measurements. Pp. 172. Submitted for the degree of M. A. in the University of Liverpool, May 1937

(51) Physical indices and clinical assessment of the nutrition of sehool children, J. Roy. Statist. Soc. 101: 1-52, Part I, '38

(52) KOCH, E. W.: See reference contained in (129) Wroczynski

(52a)KRUSE, H. D., PALMER, C. E., SCHMIDT, W., and WIEHL, D. G., Medical evaluation of nutritional status; methods used in a survey of high sehon! students, Milbank Memorial Fund Quart. 18: 257-29s, July" 40.

(5.9) LEIGHTON, G., and CLARK, M. L. : See reference contained in (44) Harris, p. 262 , Dec. $18, ' 37$

(54) LEIPOLDT, C. L., A. C. H. Index as applied to South African boys: See reference contained in (99) Seantlebury

(5.5) LE RICHE, H., A. C. H. Index as applied to boys and girls in selected Pretoria schools, South Afriean J. M. Sc. 3: 60-62, April '38

(56) LINCOLN, E. A., Reliability of anthropometric measurements, Pedagogical Seminary and J. Genetic Psyehol. 38: 445-450, Dee. '30

(57) LISHMAN, F. J. G. A scheme of elinical assessment of unt rition and a survey of the nutritional state of elementary school children in Gloncestershire, 1938, in Annual Report of the Gloweestershire [England] School Medical Oflicer (Dr. K. Cowan) for 1938. Pp. 22. London and Southend: W. H. Houldershaw, Ltd.

(58) - How do we assess nutrition? Correspondence to the edfitor, Pub. Health 51: 341, Aug. '38

(59) LOEWENTHAL, L. J. A., Effect of addition of nilk to dict of scolool boys in Buganda, East African M. J. 15:35-45, M:1y' '38

(60) LUCAS, W. P., PRYOR, H. B., BOST, C., POPE. S. T., and HENDERSON, M. C., Growth problems and their relation to zones of normal physiolngic reactions, J. Pediat. 1:572-592, Nor. '32 
(61) McCARRISON, R., Nutrition and national health, J. Roy. Soc. Arts 84: 1047-1107, Aug. 2S, '36

(62) McPHERSON, C. A., The A. C. H. Index and other assessments of the nutritional state contained in Leicester [England] Education Committee: Annual Report of the School Medical Officer for 1938. Pp. 9

(63) MAGEE, H. E.: See reference contained in (44) Harris, pp. 225-229, Nov. $27,{ }^{\prime} 37$

(64) MANChESTER [ENGLAND] EDUCATION COMMitTeE, Annual Report of the School Medical Officer (Dr. Henry Herd) for 1936. Pp. 96. Manchester: Education Offices, 1937

(65) MARSHALL, E. L., Comparison of four current methods of estimating physical status, Child Development 8: 89-92, Mar. '37

(66) - Objectivity of anthropometric measurements taken on eight- and nine-year-old white males, Child Development 8: 249-256, Sept. '37

(67) MEREDITH, H. V., Reliability of anthropometric measurements taken on eight- and nine-year-old white males, Child Development 7: 262-272, Dec. '36

(68) - Stature of Massachusetts children of North European and Italian ancestry, Am. J. Phys. Anthropol. 24: 301-346, Jan.-Mar. '39

(69) Milligan, E. H. M., Chief Medical Officer, Borough of Glossop, England, Personal communication, dated Jan. 27, '38

(70) MITCheLL, H. H., Nutrition, Section II in Porto Rico; inquiry into the health nutritional and social conditions in Porto Rico as they may affect children, by Committee of American Child Health Assn. Staff. Pp. 170. New York: American Clild Health Assn., 1930

(71) - Physical measurement and nutritional status, J. Pediat. 6:316-321, Mar. '35

(72) - Study of factors associated with growth and nutrition of Porto Rican children, Human Biol. 4: 469-508, Dec. '32

( $\gamma$ 8) [Author unlisted] Nutrition of school children, Committee Against Malnutrition, Bulletin No. 9 (July 1935), p. $2 S$

(74) [Editorial] Nutrition of school children. M. Officer 59: 64-65, Feb. 12, '38

(75) [Author unlisted] Nutritional Status Indices; method of obtaining measures of musculature, subcutaneous tissue, and weight with allowance for skeletal build. (Boys and Girls, 7 to 12 years of age.) Pp. 66. New York: American Child Health Assn., 1935

(76) ORR, J. B., Influence of amount of milk consumption on rate of growth of school children: See reference contained in (44) Harris, p. 262, Dec. 18, '37

$(\sim 6 a)$ Physiological and economic bases of nutrition; assessment of the state of mutrition, J. Roy. Inst. Pub. Health and Hyg. 3: 9-24, Jan. '40

(7y) PALMER, C. E., Further studies on growth and the economic depression; comparison of weight and weight increments of elementary school children in 1.921-27 and in 1933-34, Pub. Health Rep. 49: 1453-1469, Dec. 7, '34

$(\gamma g)-$ Nutrition as a public health program, The Registered Nurse, pp. 3-7, issue of July-Aug. '38

(79) - Relation between size of frontal nasal sinuses and attacks of upper respiratory disease (common cold) and certain nose and throat conditions, Am. J. Hyg. 16: 224-232, July' 32

$(S O)$ Seasonal variation of average growth in weight of elementary school children, Pub. Health Rep). 48: 211-233, Mar. 3, '33

(81) Passed Asst. Surgeon, National Institute of IIcalth, U. S. Public Health Service, Persomal communication, dated Oct. 7, '39 
(82) PATON, D. N., FINDLAY, L., and others, Poverty, Nutrition and Growth; studies of child life in cities and rural districts of Scotland. Meclical Research Conneil, Special Report Scries, No. 101. Pp. 333. London: His Majesty's Stat. Off., 1926

(83) [Author unlisted] Physical Defects; the pathway to correction. Pp. xviit 171. New York: American Child Health Assn., 1934

(8.4) PINCKNEY, J. M., Director, Office of Nutrition and Ifealth Education Bureau, Univ. of Texas, Austin, Texas, Personal communication, dated Mar. 3, '3s

(8.5) PIRQUET, C., An ontline of the Pirquet System of Nutrition: See reference contained in (89) Roberts

$\left(S 6^{\prime}\right)$ PRYOR, H. B., Width-Weight Tables for Boys and Girls from 1 to lf vears; for men and women from 17 to 24 years. Pp. 15. Stanford University, Calif.: Stanford Univ. Press, 1936

$\left(S_{i}\right)$ and SMITH, R. T., Physical strength of adolescent girls, J. Pediat. 14: 610-617, May' '39

(88) and STOLZ, H. R.. Determining appropriate weight for bodybuild, J. Perliat. 3: 608-622, Oct. '33

(8.9) RoBERTS, L. J., Nutrition Work with Children, Second edition. Pp. xix + 639. Chicago: Liniv. of Chicago Press, 1935

(90) - BLAIR, R., LENNING, B., and SCOTT, M., Effect of milk supplement on physical status of institutional children; growth in height and in weight, Am. J. Dis. Child. 56: 2S7-300, Aug. '3s

(91) -STONE, D. M., and BOWLER, V. P., Investigation into nutrition of children of school age, M. Oflicer 60: 209-212, Nov. 12, '38; 219-220, Nov. 19, '38

(32) ROGERS, F. R. Physical Capaeity Tests in the Administration of Physical Edueation. Dissertation submitter in partial fulfilment of the requirements for doctor of philosophy at Columbia Lniv., 1925

(98) ROHRER, F., Eine nele Formel zur l3estimmung der Körperfülle: See reference contained in (S9) Roberts

(94) ROSE, M. S., The Foundation of Nutrition. Third edition. Pp. xi+625. New York: Macmillan, 1938

(95) ROSENOW, C., Weight and skeletal build, Am. J. Orthops!chiat. 3: 55-64, Jan. '33

(36) Weight and skeletal build; a rejoinder, Am. J. Orthopsychiat. 4: 258-261, April '34

(97) ROWLAND, S. R.: See referenee contained in (39) Great Britain l3oard of Education, p. 2:3

(98) ST. PAUL [MINN.] DEPARTMENT OF EDUCATION, Bureau of schonls, Report of the Dircetor of Hygiene (Dr. G. W. Snyder) [to the Commissioner of Education and Superintendent of Schools], 1937-3S. Pp. 150. 1938

(99) SCANTlebury, V., Nitrition of preschool child, M. I. Australia 2: I4S155, July $30, ' 38$

(100) SCHARFF, J. W., and SINNADORAI, S., Nilk for the schoul child: sece reference contaninerl in (4a) Harris, 1)p. $261-2(i 5,1)$ ec. $18, " 37$

(101) SCHLUTZ, F. W., Dept. of Pediatrics, Iniv. of Chicago, Physical Jitness in the Child as Reflocted by Cardio-Tascular and bihod Scrum Changes during Exercise. Personal communication, dated $11 a y$ 12, "3!)

(102)SCHMIDT, W., Nower medieal methods of appraisul of nutritional status, Anl. J. Pub. Health 30: 165-168, Feb.'40 
(103) SHERMAN, H. C., Chemistry of Food and Nutrition. Fifth edition. Pp. vii +640. New York: Macmillan, 1937

(104) - and HAWLEY, E., Calcium and phosphorus metabolism in childhood, J. Biol. Chem. 53: 375-399, Aug. '22

(10.5) SIMPSON, T. W., and WOOD, E. C., Value of certain supplements to diet of children, M. Officer 53: 125-127, Mar. 30, '35; 135-138, April 6, '35

(106) SOUTHER, S. P., ELIOT, M. M., and JENSS, R. M., Comparison of indices used in judging physical fitness of school children, Am. J. Pub. Health 29: 434-438, May'39

(107) [Editorial] State of nutrition. Lancet 2: 1257-1258, Nov. 27, '37

(108) STEGGERDA, M., and DENSEN, P., Height, weight, and age tables for homogeneous groups-with particular reference to Navaho Indians and Dutch whites, Child Development 7: 115-120, June '36

(109) STIEBELING, H. K., and CLARK, F., Planning for good nutrition in U. S. Dept. of Agriculture, Yearbook of Agriculture, 1939; food and life. Pp. 321-340. Washington: Government Printing Office, 1939

(110) STOCKWELL, G. E. S. : See reference contained in (39) Great Britain Board of Education, p. 23

(111) STUART, H. C., Standards of physical development for reference in clinical appraisement; suggestions for their presentation and use, J. Pediat. 5: 194-209, Aug. '34

(112) TURNER, C. E., Precision and reliability of underweight measurement, Am. J. Pub. Health 19: 969-979, Sept. '29

(113) —W Weighing and measuring school children, J. Outdoor Life 28: 377381, June '31

(114) TUXFORD, A. W., Estimation of physique and nutrition in children, J. Hyg. 39: 203-216, Mar. '39

(115) U. S. CHILDREN'S BUREAU, Publication No. 217, The Effect of Tropical Sunlight on the Development of Bones of Children in Puerto Rico, by M. M. Eliot. Pp. $v+122$. Washington: Government Printing Office, 1933

(116) WALLSEND [ENGLAND] EDUCATION COMMITTEE, Annual Report of the School Medical Officer (Dr. R. Rutherford) for 1937. Wallsend: 1938

(117) WARNER, E. F., Use of nutritional status indices developed by the American Child Health Association in Principles and Practices in School Health Education, Health Education Conference at Iowa City, June 1935. Pp. 16-30. New York: American Child Health Assn., 1935

(118) WARRINGTON [ENGLAND] COUNTY BOROUGH OF WARRINGTON, Annual Report to the Education Authority on School Hygiene for the Year 1935 made by G. W. N. Josepl. Pp. 84. Warrington: Mackie \& Co., Ltd., The Guardian Press, 1936

(119) WHITE HOUSE CONFERENCE ON CHILD HEALTH AND PROTECTION, Growtl and Development of the Child; Part IV, Appraisement of the Child. Pp. xix+344. New York: The Century Co., 1932

(120) WILKINS, E. H., Assessing nutrition of school children, Lancet 2: 12651267, Nov. 27, '37

(121) - Assessment of uutrition in school children, M. Officer 58: 145148 , Oct. 2, '37

(122) WILSON, H. E. C., AHMAD, B., and MITRA, D. D., Nutritional survey of schoolboys in Calcutta and Punjab by means of clinical observations, A. C. H. Index of nutrition and other measurenents, Indian J. M. Research 24: 817-837, Ja11. '37

(198) - and MrTRA, D. D., A dict and physique survey in Assau, rural Bengal, and Calcutta, Indian J. M. Research 26: 131-154, July '38 
(124) WOLFF, Die Nachwirkung der Kriegshıngerperiode auf das Schulkinderwachstum: See reference contained in (129) Wroczynski

(125) WOODBURY, R. M., Tables for infancy and early childhood, Mother and Child 4: supplement to July'23 issue

(1\%6) WOOLhaM, J. G., Assessment of nutrition, Pub. Health 50: 258-260, May '37

(127) - and HONEYBURNE, W. R., Fitness of Schoolhoys; correlations: between the results from pulse and respiratory tests, in Manchester [England] Education Committee: Annual Report of the Sehool Medical Officer (Dr. A. B. Ritchie) for 1928. Pp. 15

(128) and SPARROW, L. W., Physical Fitness of Schoolboys in Manchester [England] Education Committee; Anumal Report of the Scluon] Medical Officer (Dr. Henry Herd) for 1935. Pp. 55-68

(129) WROCZYNSKI, C., Physique and health, Bull. Health Organ. League of Nations 6: 551-682, Ang. '37

(190) ZAYAZ, S. L., MACK, P. B., SPRAGUE, P. K., and BAUMAN, A. W.. Nutritional status of school children in small industrial city, Child Devolup)ment 11: 1-25, March' 40 



